\title{
Breeding and post-breeding forest bird community dynamics in regenerating clearcuts and two-age harvests in the central Appalachians
}

\author{
Molly Erin McDermott \\ West Virginia University
}

Follow this and additional works at: https://researchrepository.wvu.edu/etd

\section{Recommended Citation}

McDermott, Molly Erin, "Breeding and post-breeding forest bird community dynamics in regenerating clearcuts and two-age harvests in the central Appalachians" (2007). Graduate Theses, Dissertations, and Problem Reports. 2538.

https://researchrepository.wvu.edu/etd/2538

This Thesis is protected by copyright and/or related rights. It has been brought to you by the The Research Repository @ WVU with permission from the rights-holder(s). You are free to use this Thesis in any way that is permitted by the copyright and related rights legislation that applies to your use. For other uses you must obtain permission from the rights-holder(s) directly, unless additional rights are indicated by a Creative Commons license in the record and/ or on the work itself. This Thesis has been accepted for inclusion in WVU Graduate Theses, Dissertations, and Problem Reports collection by an authorized administrator of The Research Repository @ WVU. For more information, please contact researchrepository@mail.wvu.edu. 
Breeding and post-breeding forest bird community dynamics in regenerating clearcuts and two-age harvests in the central Appalachians

\section{Molly Erin McDermott}

Thesis submitted to the Davis College of Agriculture, Forestry, and Consumer Sciences at West Virginia University in partial fulfillment of the requirements for the degree of

\section{Master of Science}

in

Wildlife and Fisheries Resources

Petra Bohall Wood, Ph.D., Chair James T. Anderson, Ph.D.

Catherine Johnson, Ph.D.

Division of Forestry and Natural Resources

\section{Morgantown, West Virginia}

2007

Keywords: area sensitivity, arthropod, clearcut, early-successional, edge, long-term, mature-forest birds, mist-netting, post-breeding, regeneration, residual tree retention, two-age 


\section{ABSTRACT \\ Breeding and post-breeding forest bird community dynamics in regenerating clearcuts and two-age harvests in the central Appalachians}

\section{Molly Erin McDermott}

Two-age harvesting has been used more frequently in the management of Central Appalachian hardwood stands as an alternative to clearcutting, but long-term responses of avifauna to these harvests have not been investigated during the breeding season. No studies have examined post-breeding bird communities in these harvests; recent research concerning post-breeding use of early-successional habitats has only examined clearcuts. Greater cover from predators and increased food resources in young seral forests are suspected factors behind the attraction of mature-forest birds post-breeding, and one goal was to test these hypotheses. In addition to microhabitat characteristics, avian habitat use of forest fragmented by timber harvesting may also be affected by stand attributes such as size, amount of edge, and retained basal area. My primary objectives were to 1) determine short- and long- term effects of two-age harvesting on breeding birds in comparison to clearcuts, 2) examine post-breeding bird responses to cover and food resource variables, and 3) relate post-breeding bird responses to residual basal area, stand size, and edge of young harvests.

In 1994-1996, breeding bird surveys were completed in two-age and clearcut stands as well as mature unharvested forest stands. In 2005 and 2006, I conducted point counts in the stands from the 1994-1996 study (now 19-26 years old) and in younger clearcut and two-age stands (6-10 years old). I determined differences in breeding bird metrics among these five treatments and temporal differences comparing time periods in the old harvests and unharvested stands.

I used mist-nets from late-June to mid-August 2006 to sample post-breeding bird communities in 9 regenerating stands with a gradient of residual basal areas. I measured vegetation characteristics, fruit, and arthropod resources at 10 nets within each stand. I analyzed capture data using Poisson regression and information-theoretic approaches to model selection. Vegetative cover and food variables were used to predict bird capture rates. Area and edge effects were tested in 13 stands sampled post-breeding in 2005-2006, which ranged from 4-21 ha in size, and bird metrics were contrasted among high-leave two-age $\left(5.3-7.0 \mathrm{~m}^{2} /\right.$ ha retained basal area), low-leave two-age $\left(2.0-3.7 \mathrm{~m}^{2} / \mathrm{ha}\right.$ retained basal area) and clearcut treatments using mistnet and transect data during post-breeding.

Relative abundance of early-successional breeding species was similar in young two-age stands and young clearcuts. Many of these species, which are typically absent from group selection cuts, were present in two-age stands thus supporting their promise as an alternative to clearcutting. Although the older harvests had lower overall relative abundance, species richness, and diversity, they provided habitat for Neotropical migrant mature-forest songbirds that were 
absent or uncommon in the young harvests, and several late-successional species became more common in the older harvests over the 10 year period between studies. Consequently, two-age management provides habitat for a diverse group of species assemblages as these stands mature and may be an ecologically sustainable alternative to clearcutting in landscapes where Brownheaded Cowbirds (Molothrus ater) are uncommon.

For use of harvested stands by post-breeding birds, cover variables often were among the most important. Strong positive relations between vertical complexity of the vegetation and capture rates of mature-forest birds and molting adults support the predator-avoidance hypothesis. At the net level, basal area was a poor positive predictor of bird captures, except frugivores. Although captures in two-age stands were comparable to clearcuts, residual trees within a stand tended to depress proximate capture rates. Fruit variables inconsistently predicted frugivore captures, but appeared to be important for molting birds of both age classes. Arthropod variables best explained capture rates for some groups, but the difficulty of measuring food availability for birds and the lack of data concerning post-breeding food limitation precludes forming conclusions about the resource-selection hypothesis. Two-age and clearcut stands provided habitat for many early-successional and mature-forest birds post-breeding with cover appearing to be the primary factor for use by most species.

Clearcuts and two-age harvests were used similarly by generalists and late-successional individuals during post-breeding. Early-successional birds avoided high-leave two-age stands and were more common in clearcuts. Area and edge sensitivity were evident for both matureforest and early-successional bird species. Mature-forest birds (both generalists and latesuccessional specialists) were found in fewer numbers in large stands, but edge effects were inconclusive, with more species associated with harvest edge. In contrast, early-successional species tended to use stand interiors more often and positively responded to stand size. Despite within-stand edge effects evident for several species, few birds in the forest periphery responded to harvest edge types. Mist-netting and transect surveys were important for helping to determine post-breeding habitat requirements for a variety of species. Understanding stand-specific bird survival is needed to determine the true quality of silvicultural harvests for post-breeding birds. 


\section{ACKNOWLEDGMENTS}

Funding for this project was granted by the U.S. Forest Service, Monongahela National Forest. Logistic and administrative support was provided by the USGS West Virginia Cooperative Fish and Wildlife Research Unit (special thanks to Becky Nestor!) and the Division of Forestry and Natural Resources at West Virginia University. The U.S. Forest Service and MeadWestvaco provided access to study sites and housing. Additional housing was made available by David Runkle at the Carya Refuge.

There are many individuals who contributed to my research project. First, I would like to thank my major advisor Dr. Petra Wood who gave me the opportunity to work on a graduate assistantship at WVU. Petra is patient, accessible, has made me a better writer and helped teach me the fun of SAS programming. I thank her for allowing me flexibility in shaping my research project and for her professional advice that has guided my thesis from start to finish. My graduate committee members Dr. Jim Anderson and Dr. Cathy Johnson provided continual support, cooperation, and suggestions about my thesis. Their upbeat attitudes and open minds made our partnership a pleasure. Also, I would especially like to thank Joey Herron for allowing me to obtain a bird banding subpermit under his tutelage.

This project would not have been possible without help in the field and lab. Thanks so much to my field crews of 2005: Rachel Gauza, Dan Hinnebusch, Lisa Koerner, and Toni Weidman and 2006: Kate Heyden, Jordan Rehar, Emily Samargo, and Justin Walker. I was also assisted in the field by Greg George, Patrick McElhone, and my parents. I was lucky to have hired a crew that maintained positive attitudes in adverse situations. I am forever grateful for the many hours of relentless work including less-than-fun vegetation sampling, data entry, and proofing that you gave, and I am glad to have shared the experience. Thanks for putting up with Mott.

This project was ultimately made possible by Matthew Shumar, who was out in the field almost every day and offered his invaluable skills, patience and support and challenged me along the way. Thank you for enduring this long process with me, and I will try to reciprocate!

I received assistance with property access from Pat Keyser and Aaron Plaugher on MeadWestvaco property and from Cathy Johnson, Dan Arling, and Fernow Experimental Forest cooperators and crew on the Monongahela National Forest. Jeff Duguay provided detailed directions to the old two-age study plots. I thank Tim Dellinger for assistance with setting up study plots on MeadWestvaco property and for inspiring the post-breeding component of my project.

I am grateful to Linda Butler, Jim Amrine, Vicki Kondo, and Kyle Hartman for logistic support for the insect sampling component of my study. Vicki was indispensable in her help identifying arthropods, and Patrick McElhone assisted with the sorting.

I would also like to thank the late George Seidel for help with statistics and also, the SAS technical support hotline, both of whom helped me write some crazy SAS codes.

I thank other fellow graduate students who provided advice, encouragement, or just a friendly smile along the way. Finally, I am grateful to my friends and family for their encouragement and support. Thank you!! 


\section{Table of Contents}

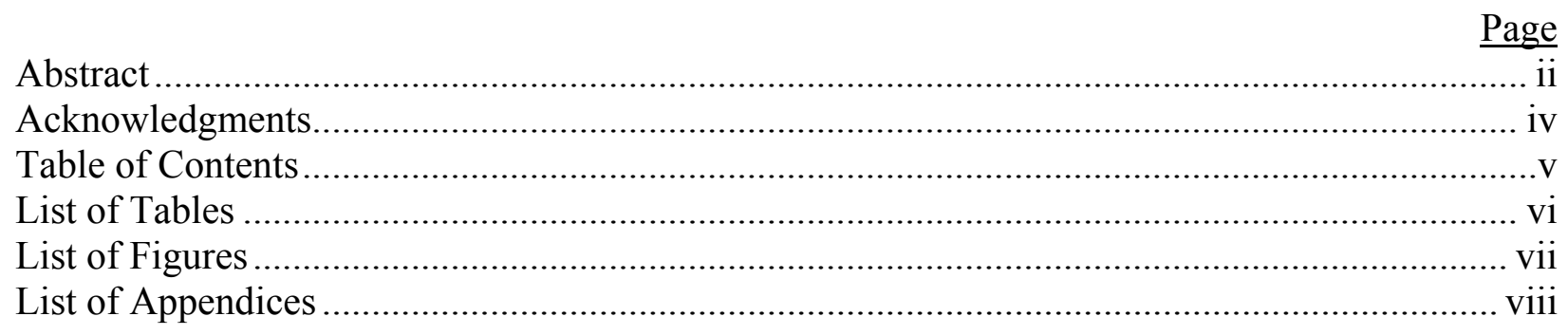

Chapter 1: Literature review of forest management effects on bird communities

Introduction

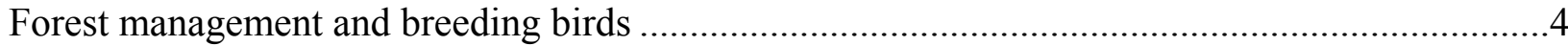

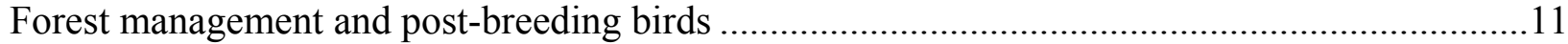

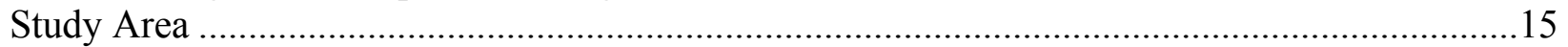

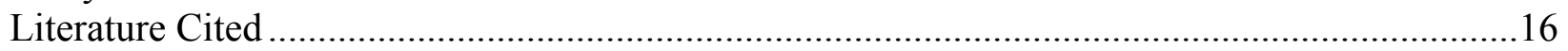

Chapter 2: Short- and long-term implications of clearcut and two-age silviculture for forest breeding bird conservation

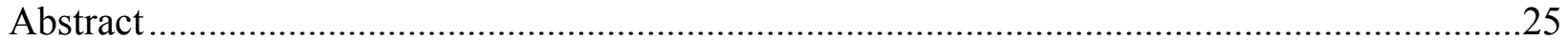

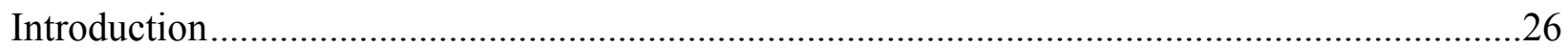

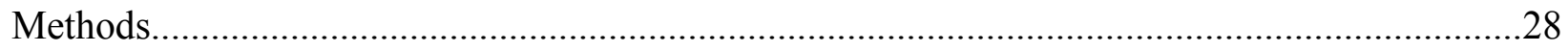

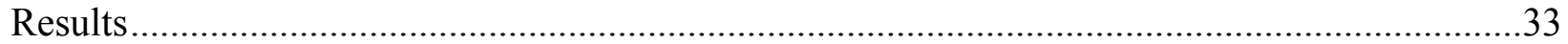

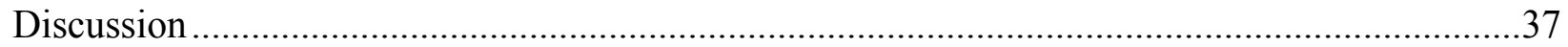

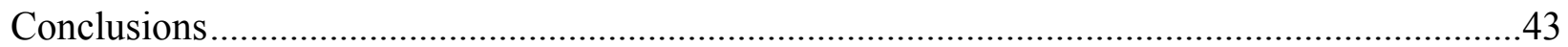

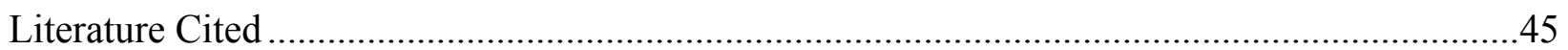

Chapter 3: The value of microhabitat cover and food resources in young clearcut and twoage harvests for late- and post-breeding birds

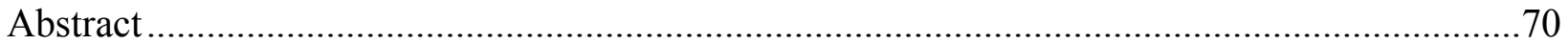

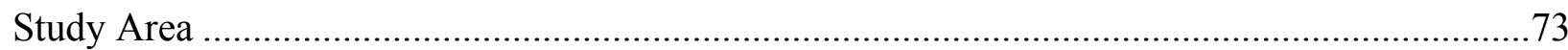

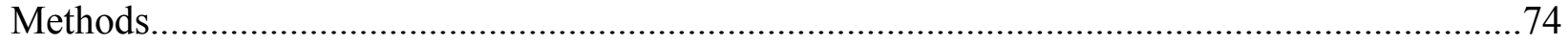

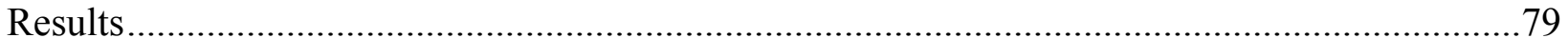

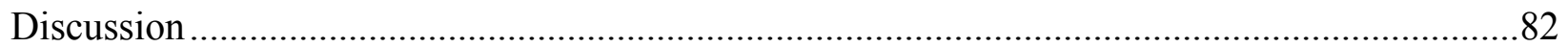

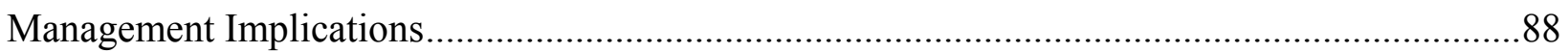

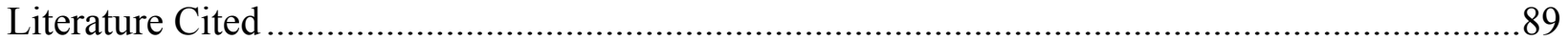

Chapter 4: Post-breeding bird responses to residual tree retention, stand size, and edge in regenerating stands

Abstract.

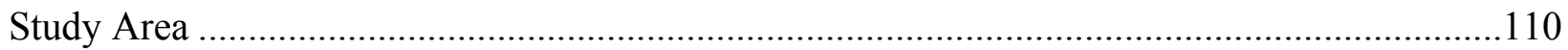

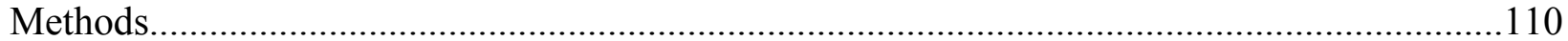

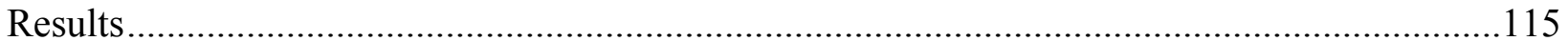

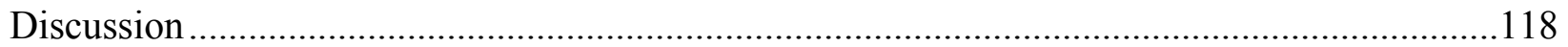

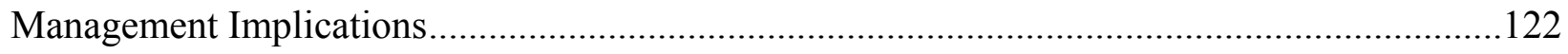

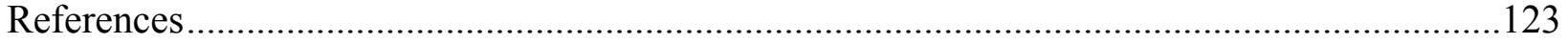




\section{Chapter 2:}

\section{List of Tables}

Table 1. Table 1. Mean relative bird abundance, species richness, and diversity $( \pm \mathrm{SE})$ per stand (within $50 \mathrm{~m}$ ) in each of the 5 treatments during 2005-2006 in north-central West Virginia.....50

Table 2. Mean per stand $( \pm \mathrm{SE})$ for habitat variables (prior to transformation) measured during 2005 and 2006 in 0.04 ha plots around point count stations in five treatments in north-central

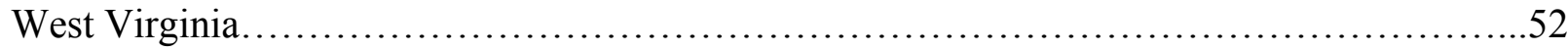

Table 3. Mean relative bird abundance, species richness, and diversity ( \pm SE) per stand (100-m radius plots) in 3 treatments during 1994-1996 and 2005-2006 on the Monongahela National

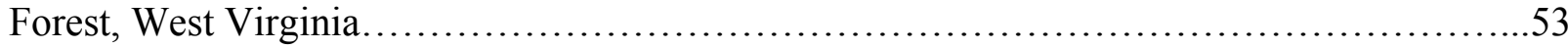

Table 4. Mean per stand $( \pm \mathrm{SE})$ for habitat variables (prior to transformation) measured from 1994-1996 and from 2005-2006 in 0.04 ha plots around point count stations in three treatments on the Monongahela National Forest, West Virginia.

\section{Chapter 3:}

Table 1. Net-level vegetative and food resource variables used to model bird use of earlysuccessional habitats during the post-breeding period in north-central West Virginia, 2006. Resources were sampled from late-June through mid-August

Table 2. Species of hatch year birds (HY), adults (AHY), and post-breeding (PB) adults classified by habitat and foraging guilds captured by mist-nets in 2006 in north-central West Virginia. Post-breeding adults were individuals that showed no sign of breeding and had begun pre-basic molt. .

Table 3. Number of individuals captured for groups analyzed in regression models. Birds were captured by mist-nets in north-central West Virginia, July-August 2006.

Table 4. Poisson regression analysis on bird capture rates by species, guild, and age group. Models were selected using Akaike's Information Criteria $\left(\mathrm{AIC}_{c}\right)$ and model weight. Models with $\Delta i \mathrm{AIC}_{c}<2$ and weight $\geq 10 \%$ are presented $\ldots \ldots \ldots \ldots \ldots \ldots \ldots \ldots \ldots \ldots \ldots \ldots \ldots \ldots$

\section{Chapter 4:}

Table 1. Mean ( \pm SE) species richness and number of individuals encountered by mist-net and transect surveys per station, year, round and habitat guild and the and proportion of each guild in north-central West Virginia during 2005-2006.

Table 2. Mean $( \pm$ SE) bird metrics per station, round and year (2005 and 2006) sampled by transect and mist-net surveys in West Virginia. Only species with a significant treatment or area effect $(P \leq 0.10)$ are presented. 
Table 3. Edge sensitive species sampled by transect and mist-net surveys from 2005-2006 in West Virginia. Estimate indicates relationship of bird variable to distance to forested edge of stand. Only species with a significant edge effect $(P \leq 0.10)$ are presented.

Table 4. Periphery bird use of harvested study stands from 2005-2006 in West Virginia. Positive estimates indicate a greater relative abundance of birds near edges of stands with high retained basal area, vegetation height, or area.

\section{Chapter 1:}

\section{List of Figures}

Figure 1. Aerial view of a two-age stand on the Fernow Experimental Forest 3 years postharvest in Parsons, West Virginia. Residual trees were 83 years old. Photo taken by J.N. Kochenderfer in 1984.

Figure 2. Location of study sites in West Virginia. Point count and mist-net stands outside of the Monongahela National Forest boundary were located on MeadWestvaco property. ..........22

Figure 3. Clearcut (top), low-leave two-age (middle; with a Chestnut-sided Warbler captured in this stand), and high-leave two-age (bottom) treatments used in post-breeding study.

\section{Chapter 3:}

Figure 1. Relationship between capture rate (captures per 100 net-hours) and vertical complexity index for mature forest adult $(\mathrm{Y}=0.0119 \mathrm{x}+0.6402)$ and $\mathrm{HY}(\mathrm{Y}=0.0037 \mathrm{x}+1.2514)$; and earlysuccessional adult $(\mathrm{Y}=-0.0231 \mathrm{x}+3.4625)$ and $\mathrm{HY}(\mathrm{Y}=-0.049 \mathrm{x}+5.6745)$ insectivorous birds in early-successional habitats of north-central West Virginia in 2006.

Figure 2. Captures per 100 net-hours as a function of arthropod biomass for all mature-forest ( $\mathrm{Y}$ $=3.4126 \mathrm{x}+1.1905)$ and early-successional adult insectivores $(\mathrm{Y}=1.165 \mathrm{x}+1.6186)$, adult veeries (seasonal frugivores; $\mathrm{Y}=1.8956 \mathrm{x}+0.0747)$, and early-successional hatch year $(\mathrm{HY})$ birds $(\mathrm{Y}=-4.4924 \mathrm{x}+2.4502)$ in early-successional habitats of West Virginia in 2006.

Figure 3. Relationship between capture rate (captures per 100 net-hours) and basal area for all frugivores $(Y=0.0888 \mathrm{x}+1.319)$, red-eyed vireo adults $(\mathrm{Y}=-0.0322 \mathrm{x}+0.464)$, Canada warbler hatch year $(\mathrm{HY})$ birds $(\mathrm{Y}=-0.016 \mathrm{x}+0.2159)$, and common yellowthroats $(\mathrm{Y}=-0.0414 \mathrm{x}+$ 0.3158 ) in early-successional habitats of north-central West Virginia in 2006.

Figure 4. Relationship between ripe fruit and adult (AHY) molt score index $(\mathrm{Y}=0.0061 \mathrm{x}+$ 0.5659 ) in early-successional habitats of north-central West Virginia in 2006.

Figure 5. Relationship between capture rate (captures per 100 net-hours) and understory stem density for all mature forest insectivores $(\mathrm{Y}=-0.0029 \mathrm{x}+3.4177)$ and post-breeding earlysuccessional adults $(Y=0.0012 \mathrm{x}+0.3862)$ in early-successional habitats of north-central WV in 2006. The relationships between species richness adjusted per 100 net-hours $(\mathrm{Y}=-0.0061 \mathrm{x}+$ $6.0599)$, and body condition index $(\mathrm{Y}=-0.0032 \mathrm{x}+2.5313), \&$ stem density are also shown...102 
Figure 6. Comparison of indexes of body condition $(\mathrm{Y}=0.0068 \mathrm{x}+1.6306)$ and adult molt $(\mathrm{Y}=$ $0.0064 x+0.2031)$ as related to vertical complexity in early-successional habitats of north-central

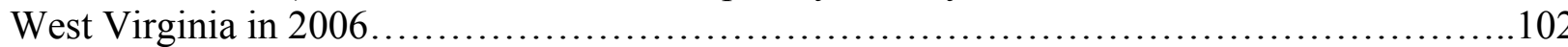

\section{Chapter 4:}

Figure 1. Relationship between stand size and capture rate (per 100 net-hours) for three habitat guilds sampled by mist-nets in West Virginia post-breeding during 2005-2006.

Figure 2. Relationship between stand size and mean relative abundance for three habitat guilds sampled by transect surveys in West Virginia post-breeding during 2005-2006. . .

\section{Chapter 2:}

\section{List of Appendices}

Appendix 1. Classifications of bird species detected by point counts in north-central West Virginia during 1994-1996 and 2005-2006 based on breeding habitat associations and migratory strategy....

Appendix 2. Mean relative bird abundance, species richness, and diversity $( \pm \mathrm{SE})$ per stand (100-m radius plots) in 3 treatments during 1994-1996 and 2005-2006 on the Monongahela National Forest, West Virginia.

\section{Chapter 3:}

Appendix 1. Candidate sets of models used for American redstart, Canada warbler, chestnutsided warbler, common yellowthroat, hooded warbler, and captures by habitat guild....

Appendix 2. Candidate sets of models used for gray catbird, red-eyed vireo, veery, all postbreeding adults, body condition and molt response variables.............................103

Appendix 3. Candidate sets of models used for species richness..........................103

Appendix 4. Candidate sets of models used for frugivore capture rates..................... 104

Appendix 5. Candidate sets of models used for indigo bunting capture rates....................104

Appendix 6. Biomass of representative orders of arthropods averaged for each net and round. Arthropods were sampled from June through August 2006 in early-successional habitats in north-central West Virginia. .......................................................... 105

\section{Chapter 4:}

Appendix A. Species of hatch year birds (HY) and adults (AHY) by habitat guild captured by mist-nets and all ages detected within $50 \mathrm{~m}$ by transects between late June and mid-August in 2005-2006 in West Virginia. 


\section{Chapter 1}

Literature review of forest management effects on bird communities 


\section{Introduction}

Forest management and other anthropogenic land use practices have come under scrutiny for altering or eliminating forest breeding bird habitat. The removal of trees affects the forest breeding bird community to different extents, depending on such factors as the amount of tree removal, landscape and forest type, and area remaining of the surrounding core forest (Maurer et al. 1981; King \& DeGraaf 2000). Additionally, as vegetation in harvested stands changes over time, transformations in forest bird communities are anticipated (Cody 1981; Maurer et al. 1981). The ultimate research goal is to determine which types of harvest and how much disturbance will be compatible with native forest bird population persistence.

Each species is uniquely impacted by timber harvesting. Although large-scale removal of trees can negatively affect forest interior species (Hagan et al. 1996), early-successional breeding species benefit from such activities (DeGraaf \& Yamasaki 2003). Conversely, selective harvests

that remove a small percentage of trees create suitable habitat for gap-associated species and may have minimal impacts on mature-forest species, while not creating any habitat for earlysuccessional breeders (Annand \& Thompson 1997; Robinson \& Robinson 1999; King et al. 2001). Clearly a balance of disturbance levels is needed to maintain avian biodiversity in forested landscapes (Hunter et al. 2001).

Clearcutting, a silvicultural technique that involves removing most or all trees of a stand in a single harvest (Smith et al. 1997), temporarily creates early-successional habitat. Two-age harvesting is an alternative practice that may be more acceptable to the public eye because of the residual overstory trees that are left after harvest (Smith et al. 1989). These timber harvesting methods create suitable habitat for some species assemblages, but for others, the resulting habitat is marginal or inferior. Thus, a variety of management prescriptions must be considered to provide habitat for all native forest bird species assemblages.

Nearctic-Neotropical migrant forest songbirds have shown some of the highest population declines among breeding birds in recent years (Robbins et al. 1989; Sauer et al. 2005). Several forest interior species such as Eastern Wood-Pewees (Contopus virens), Cerulean Warblers (Dendroica cerulea), and Kentucky Warblers (Oporornis formosus) have experienced significant declining trends over the past 40 years (Sauer et al. 2005). Although the causes for these declines are not completely understood, habitat loss and fragmentation on breeding and 
wintering grounds are among the principal suspected factors (Askins et al. 1990). Timber harvesting may represent a loss of habitat for area-sensitive, forest interior species of birds that require large tracts of unfragmented mature forest to breed. Thus, concerns about the effects of forest management on avian biodiversity are warranted (Hunter 1990).

Declines in disturbance-dependent bird populations, especially in the Northeast, also have been well documented (Hunter et al. 2001; Sauer et al. 2005). Although some shrubland species are thought to be returning to pre-European levels of low abundance (Hunter et al. 2001), many species are in decline and disappearing from all or part of their range suggesting that the amount of suitable habitat is currently lacking (DeGraaf \& Yamasaki 2003). The declines of these species parallel the maturation of eastern deciduous forest and old field succession, both of which represent a loss of early-successional habitat. This loss of habitat may be driving populations of some shrub-associated species to unsustainable levels. Silvicultural treatments that create openings or patches of young forest are important for early-successional species (Gram et al. 2003); therefore, forest management may be an important tool for mimicking the natural disturbances necessary to support these species.

Although effects of silvicultural systems on breeding bird density and demographics have been the focus of much research, comparatively little is known about how forest management affects birds during other times of the year (Pagen et al. 2000). Breeding habitat needs of most North American species are relatively well understood, but there is still much to be learned about habitat use during migration, wintering, and of particular interest here, postbreeding.

The post-breeding period, defined as the time interval between the fledging of young and migration, is one of the hardest to study and consequently least known part of the avian life cycle (Baker 1993). Several studies have demonstrated that many bird species use early-successional habitat such as silvicultural clearcuts extensively during this period. Unpredictably, forest interior species have been detected in numbers rivaling edge and early-successional species in these habitats (Rappole \& Ballard 1987; Pagen et al. 2000; Marshall et al. 2003; Vitz \& Rodewald 2006). Juveniles appear to make deliberate movements from their natal grounds in mature forest into early-successional habitat before migration (Anders et al. 1998; Vega Rivera et al. 1998; White et al. 2005; T. Dellinger, unpublished data). 
These studies suggest that some birds may benefit from, or even require, the availability of different habitats during the breeding and post-breeding periods. Silvicultural treatments that result in high shrub cover during regeneration could be valuable not only for nesting earlysuccessional species, but also for species associated with mature forest that require increased energy resources and protection from predators during this critical life stage, the post-breeding period.

This thesis is organized into three chapters that will present and discuss three case studies. The first study focuses on the impacts of clearcut and two-age harvests of different ages on forest breeding birds and the changes in these harvests over time. The second concerns postbreeding bird microhabitat use as related to cover and food resources in regenerating stands. The final chapter concentrates on area and edge-sensitivity and responses to residual trees in young harvests by post-breeding birds.

\section{Forest management and breeding birds}

Silvicultural practices impact wildlife populations by altering the structure and composition of forest ecosystems (King \& DeGraaf 2000). Regeneration methods vary in intensity and purpose and include clearcutting, seed-tree, shelterwood, and selection cutting (Smith et al. 1997). Most research concerning forest management impacts on forest-dependent bird communities in the past 30 years has been conducted on the clearcutting and partial harvesting methods (i.e., selection cuts and commercial thinning; Sallabanks et al. 2000).

\section{Selective harvests}

Selective harvesting, or selection regeneration, is an uneven-aged timber harvesting method used to create small openings similar to natural blowdowns of single trees or small groups (Lorimer 1989). These techniques mimic fine-scale disturbances and promote retention of mature trees and other late-successional features (Chambers et al. 1999). Many studies have shown that gap-dependent species initially increase in abundance but then are gradually displaced by mature-forest dependent species which often use and breed successfully in these stands (Annand \& Thompson 1997; Whitman et al. 1998; Robinson \& Robinson 1999; Jobes et al. 2004). 
Bourque and Villard (2001) studied two Neotropical migrant species to determine differences in breeding bird density and nesting success among recent selection cuts, 30-year old selection cuts and unharvested forest. The results suggest that effects of these harvests are species-specific: there was no difference in Black-throated Blue Warbler (Dendroica caerulescens) reproductive performance among treatments, but densities were higher in selection cuts; whereas Ovenbird (Seiurus aurocapillus) densities were lower, and they had lower reproductive success in the selection cuts compared to the unharvested plots.

A study of the effects of forest thinning on breeding birds in Massachusetts found that thinned stands had significantly more bird species than unthinned stands, and furthermore, of species detected more than once, nine species only occurred in thinned stands whereas one species occurred exclusively in unthinned stands (DeGraaf et al. 1991). Thus, selective harvesting appears to increase bird community richness and diversity.

Most research concerning partial harvesting effects on birds demonstrates that latesuccessional-associated species occur in high numbers in group and single-tree cuts after several years post-harvest and are not negatively affected by these methods in the long-term. However, species associated with early-successional habitat are typically absent from the small openings created by selection cutting (Annand \& Thompson 1997; Robinson \& Robinson 1999; King et al. 2001). Annand and Thompson (1997) found that abundances of species such as Eastern Towhees (Pipilo erythrophthalmus), Prairie Warblers (Dendroica discolor), Yellow-breasted Chats (Icteria virens), and Indigo Buntings (Passerina cyanea) all declined as opening size associated with the harvesting treatments decreased. Also, as time after selection harvest increased, abundances of gap and shrub-dependent species tended to decrease, and most species were absent 10 years after harvest (Robinson \& Robinson 1999). Although selective harvesting may be a viable option for maintaining mature-forest bird populations, other types of silviculture are needed to provide adequate habitat for early-successional breeders.

\section{Clearcuts}

Clearcutting is a widely used even-aged silvicultural technique that removes the entire overstory in one harvest (Smith et al. 1997). Both shade-tolerant and shade-intolerant tree species quickly regenerate. However, there has been a widespread public disapproval of this technique, typically for aesthetic reasons (Costello et al. 2000; Miller et al. 2004), and general 
concern about edge and fragmentation effects that may contribute to regional avian population declines (Wilcove 1988). Clearcutting has proved detrimental to some forest-breeding birds by indirectly causing reduced productivity and reproductive failure in some contexts (Manolis et al. 2002). Yet most opponents of clearcutting are not knowledgeable about tree regeneration or the importance of early-successional habitat to shrubland wildlife.

Evidence exists that clearcutting may be compatible with forest bird conservation in certain landscapes. Specifically, clearcuts situated in extensively forested landscapes have not been shown to cause declines of forest interior species, especially in the long-term (Welsh \& Healy 1993; Boardman \& Yahner 1999; Yahner 2000). The loss of habitat for these species is temporary, and many forest interior species return after 10 to 15 years once stands reach a polesapling stage (Duguay et al. 2001). In contrast, clearcutting in patchy forested habitats, such as suburban woodlots and agricultural landscapes, accelerates edge effects such as nest parasitism and predation, and habitat fragmentation results in isolated patches of forest that may no longer support area-sensitive forest-breeding species (Welsh \& Healy 1993, Paton 1994).

Forest interior species may exhibit positive or negative responses to clearcutting. For instance Thompson et al. (1992) found that Scarlet Tanagers (Piranga olivacea) and Red-eyed Vireos (Vireo olivaceus) had lower densities in clearcuts, but Black-and-white Warblers (Mniotilta varia), Worm-eating Warblers (Helmitheros vermivorus), and Kentucky Warblers were more abundant on early and mid-successional clearcut stands in the Missouri Ozarks. Moreover, nest predators (including American Crows (Corvus brachyrhynchos) and Blue Jays (Cyanocitta cristata)) and brood parasites (Brown-headed Cowbirds (Molothrus ater)) were not more abundant in landscapes with regenerating clearcuts relative to landscapes without harvesting (Thompson et al. 1992). Brown-headed Cowbirds are declining throughout their range, especially in the Central Appalachians (Sauer et al. 2005), where their continual decline will benefit host bird species.

Reduced productivity and high nest predation for mature-forest birds have been linked to stands with a low basal area such as clearcuts (Ross 2001). Nest predation rates also may be explained by differences in regional forest cover, so that in extensive blocks of contiguous forest, predation rates are typically much lower than in highly fragmented landscapes (Annand \& Thompson 1997; King et al. 2001). Clearcuts situated within a predominantly forested matrix 
seem to have minimal edge effects due to fewer avian predators and brood parasites (Paton 1994; King et al. 1996; Donovan et al. 1997; Duguay et al. 2000; Gram et al. 2003).

Silvicultural clearcutting that mimics the frequency and scale of natural disturbances may be an efficient means for providing habitat for early-successional species (Annand \& Thompson 1997; Brawn et al. 2001; Fink et al. 2006). Some research has shown that clearcuts within a primarily forested landscape provide habitat for early-successional species and increase species diversity, while not affecting any forest-interior species in the long-term (Welsh \& Healy 1993; Boardman \& Yahner 1999; Yahner 2000). Early-successional species exhibit higher reproductive success as harvest intensity increases and residual basal area decreases accordingly (Ross 2001). Shrub-associated birds are most abundant during early regeneration stages but become less common as the forest matures (Thompson et al. 1992; Welsh and Healy 1993; Yahner 2000). Thus the early-successional habitat created by clearcuts is ephemeral due to rapid regeneration, especially of northern hardwood forests.

Group selection cuts, which maintain mature-forest bird communities, are not a good alternative to clearcuts for creating suitable habitat for early-successional species (Annand \& Thompson 1997; Robinson \& Robinson 1999; Costello et al. 2000; King et al. 2001). Only species that will use mid- and early-successional habitat, such as Chestnut-sided Warblers (Dendroica pensylvanica), may experience similar responses to both treatments (King et al. 2001). Daily nest survival did not differ between clearcuts and group cuts indicating that these types of harvest provide similar habitat for this warbler (King et al. 2001). However, selection harvests do not create large enough openings to support area-sensitive early-successional species (Annand \& Thompson 1997; Robinson \& Robinson 1999; King et al. 2001).

\section{Two-age silviculture}

Two-age harvesting, has received increased consideration in the management of the central Appalachian hardwood forests (Smith et al. 1989; Miller et al. 1995). Recently, many forest management plans have required canopy trees to be retained in clearcuts. Such harvests, often referred to as clearcuts with deferred residuals or deferment cuts, still provide habitat for many early-successional species, and total bird abundance may be higher in these stands than in mature-forest (Boardman \& Yahner 1999). Deferment cutting has been applied in mature, second growth Appalachian hardwoods to create two-aged stands (Perkey et al. 1999). In this 
method, 25-50 residual canopy trees are left per hectare, and all other stems $>2.5 \mathrm{~cm}$ diameter at breast height are cut (Miller et al. 2004). A dominant mature age class (residual trees) and a regenerating age class result from the harvest. The resultant vertical stratification provides habitat for both shrub and canopy-foraging species (Chambers et al. 1999). A two-age harvest resembles a seed tree or shelterwood cut, except that residual canopy trees remain for the entire rotation (Figure 1).

Two-age silviculture is a suggested alternative to clearcutting because this type of harvest is more aesthetically pleasing. Furthermore, regeneration in two-age harvests is similar to that of clearcuts with stands containing both shade-tolerant and shade-intolerant species, except that two-age stands retain residual overstory trees that provide vertical stratification important for increasing stand diversity of wildlife (Smith et al. 1989; Perkey et al. 1999).

In West Virginia, Weakland (2000) examined songbird abundance and nesting success in two-age cuts immediately after harvest and in unharvested areas. Abundance of forest interior and most other songbird species did not differ among treatments post-harvest despite marked differences in vegetative structure in the two-age stands. Nest survival was greatest in the harvested stands, and less than one percent of nests were parasitized by cowbirds suggesting that two-age harvesting does not negatively affect songbirds in the short term in this industrial forest.

Even-aged stands that retain some overstory trees in Pennsylvania have a greater diversity of breeding birds compared to similarly aged stands without residual trees (Boardman \& Yahner 1999). Boardman and Yahner (1999) observed similar species richness and higher overall abundance in deferment cuts 1-5 years post-harvest compared to unharvested stands. Deferment cuts had 24\% canopy cover and retained 15-20 overstory trees per ha. Earlysuccessional species (e.g., Common Yellowthroat (Geothylpis trichas), Chipping Sparrow (Spizella passerina), and Eastern Towhee) were abundant in the deferment cuts, and some mature-forest species such as Scarlet Tanagers used the residual trees in the young cuts for singing perches. Reproductive success was not examined.

Baker and Lacki (1997) studied bird communities in Kentucky in unharvested stands, clearcut stands, and two-age stands with two levels of residual tree retention for 1 year preharvest and 2 years post-harvest. All harvest levels resulted in higher relative abundance, species richness, and species diversity compared to the unharvested control, which had similar bird community composition in pre- and post-harvest years. Level of harvest (i.e., clearcut, two-age 
light, or two-age heavy) had no discernible effect on the bird communities; birds responded similarly to these three harvest treatments. Many early-successional species (e.g., Indigo Bunting, Yellow-breasted Chat, and Eastern Towhee) responded positively to harvesting. Some mature-forest species used the harvests more than unharvested stands. For example, Hooded Warblers (Wilsonia citrina) were most abundant in the two-age stands. However, some forest interior species (e.g., Acadian Flycatcher (Empidonax virescens) and Red-eyed Vireo) were most abundant in unharvested stands, and one (Ovenbird) avoided the harvested treatments.

Although reproductive success was not evaluated, Brown-headed Cowbirds became abundant in all harvested stands (Baker and Lacki 1997) suggesting that lower reproductive output caused by presence of a brood parasite could cause this area to become a sink. The surrounding landscape for this study was $73 \%$ farmland, explaining the dominance of cowbirds compared to more extensively forested areas, and providing evidence that timber harvests in agricultural-dominated landscapes could have negative repercussions for host species. This study merits a closer look at reproductive success in these harvests.

The Kentucky plots were revisited in 2005 and 2006 (White et al. unpublished data). In the nine years between surveys, abundances of early-successional species dropped greatly. Additionally, total bird abundance, species richness, and diversity declined to below pre-harvest levels in all treatments (but declined more in the harvests relative to unharvested stands). Although Brown-headed Cowbirds returned to low pre-harvest levels, mature-forest species such as the Wood Thrush (Hylocichla mustelina) and Ovenbird did not return to pre-harvest abundances in any of the stands following harvest. Despite low relative abundances in all stands, 13 years post-harvest the two-age treatments had greater species richness and diversity compared to clearcut and unharvested stands thus maintaining their promise as a clearcut alternative.

Duguay et al. (2001) observed changes in forest stands harvested by clearcutting and the two-age system approximately 10-15 years post-harvest in West Virginia. Songbird densities were higher in two-age cuts compared to clearcuts, and some mature-forest species such as Canada Warblers (Wilsonia canadensis) were found exclusively in the two-age cuts. Species associated with early-successional or edge habitat also were observed in two-age stands including American Goldfinches (Carduelis tristis), Chestnut-sided Warblers, Mourning Warblers (Oporornis philadelphia) and Indigo Buntings. In addition, more species were exclusive to or reached higher densities in two-age stands compared to both clearcuts and 
unharvested stands (Nichols 1996). However, forest interior species were most abundant in unharvested stands.

Reproductive success (nest survival) also was studied in the West Virginia plots (Duguay et al. 2001). Daily nest survival was highest in unharvested stands; but all treatments had sufficient reproductive success for some species, such as the Wood Thrush, to be considered source populations. Nest survival rates within a cut did not vary significantly by distance to edge of stand indicating a low incidence of edge-related nest failure. Moreover, nest parasitism rates by Brown-headed Cowbirds were low, but associated with the two-age treatment, further signifying that two-age harvesting may not be appropriate in landscapes where cowbirds are abundant. Although there were more parasitized nests in the two-age stands, there were no indications of lower reproductive output (driven by increased nest predation) in these stands; thus, retention of residual trees does not necessarily present an ecological trap for forest birds (Stuart-Smith \& Hayes 2003). These studies have provided insights into the effects of two-age harvesting on breeding birds in the short term. No studies have examined bird communities in two-age stands beyond 15 years post-harvest.

\section{Forest management and early-successional breeders}

Although forest management may negatively impact some mature-forest breeding bird species, forest regeneration is useful and necessary in the Northeast for conservation of many shrubland-associated species (DeGraaf \& Yamasaki 2003). Several species that rely on earlysuccessional habitat (including the Golden-winged Warbler (Vermivora chrysoptera), Prairie Warbler, Yellow-breasted Chat, Field Sparrow (Spizella pusilla), and Indigo Bunting) are declining in West Virginia, and BBS trends indicate that the rates of decline have increased in the last 20 years as more old fields and young second growth forest have regenerated to mature forest (Sauer et al. 2005). Furthermore, these species are experiencing more widespread declines than forest-interior birds (Askins et al. 1990).

Natural disturbances are no longer prevalent, and as a result, suitable habitat for earlysuccessional species is lacking. Silviculture is an efficient means for creating early-successional habitat. Additionally, regenerating clearcuts provide habitat for more individual birds, which tend to have greater nesting success compared to birds in other scrub-successional habitats (Fink 
et al. 2006). Two-age harvests also provide habitat for many early-successional species in the short-term (Baker and Lacki 1997; Boardman \&Yahner 1999; Duguay et al. 2001).

Some early-successional species such as the Golden-winged Warbler are known to be area-sensitive (Hunter et al. 2001), so it is important to determine if small open patches typically created by many silvicultural systems are large enough to support these species in the long-term. Some studies have not found a significant relationship between size of harvested stands and species richness, relative abundance, or reproductive effort (Boardman \& Yahner 1999; Krementz \& Christie 2000; but see Rudnicky \& Hunter 1993). Clearcut size (ranging from 2 to $52 \mathrm{ha}$ ) did not seem to affect community metrics, and rare birds were no more likely to be detected in large stands than in small ones (Krementz \& Christie 2000). Additionally, Rodewald and Vitz (2005) found only weak evidence for area sensitivity of early-successional species in Ohio. Nevertheless, shrubland nesters may avoid edges, so small, narrow, or irregularly shaped patches of early-successional habitat may not be suitable for these species (Rodewald \& Vitz 2005).

More research focusing on a gradient of early-successional patch sizes needs to be conducted. The effects of size and successional stage of different types of silvicultural treatments on forest bird communities must be investigated to derive management strategies that will balance the needs of the entire suite of native shrubland and forest species. Ultimately, tradeoffs among habitat guilds must be made when managing at the stand level.

\section{Forest management and post-breeding birds}

Evidence exists that birds of all forest habitat associations use early-successional habitats such as young second growth forest during the post-breeding period. Many species of matureforest breeding songbirds, including Worm-eating Warblers, Kentucky Warblers, Hooded Warblers, Ovenbirds, Wood Thrushes, and Scarlet Tanagers, disperse to early-successional habitat after young have fledged (Rappole \& Ballard 1987; Pagen et al. 2000; Marshall et al. 2003; Vitz \& Rodewald 2006).

Mature-forest born juvenile Wood Thrushes wearing radio-transmitters were tracked into both early and mid-successional habitat (Anders et al. 1998; Vega Rivera et al. 1998; T. Dellinger, unpublished data). Wood Thrush fledglings moved an average of 1.5 (Vega Rivera et al. 1998) and $2 \mathrm{~km}$ (Anders et al. 1998) into young forest from their natal home ranges. In 
Virginia adult Scarlet Tanagers had different habitat requirements in the post-breeding period relative to breeding (Vega Rivera et al. 2003). Several adults were tracked $>300 \mathrm{~m}$ into postbreeding habitat with early-successional characteristics. Color-banded adult Worm-eating Warblers were caught in clearcuts an average of $317 \mathrm{~m}$ from their breeding territories (Marshall et al. 2003), further indicating that some species may move far from their breeding territories to reach young regenerating forest.

In a southeastern section of the Monongahela National Forest, many mature-forest species were found in family groups in clearcuts that were 1 to 7 years old at the initiation of the study (Marshall et al. 2003). An estimated 50\% of the species found breeding in adjacent forest plots were captured in the clearcuts post-breeding (Marshall et al. 2003). Rappole and Ballard (1987) captured 10 species in early-successional habitat during the post-fledging period that were out of their normal breeding habitat (riparian forest).

Vitz and Rodewald (2006) also found evidence that clearcuts may benefit mature-forest breeding songbirds. In Ohio, they captured as many mature-forest birds as early-successional individuals during the post-breeding period. Variability in habitat use was not explained by differences in vegetative structure, arthropod abundance or fruit abundance among the clearcut stands, but mature-forest birds preferred smaller regenerating clearcuts and avoided edges.

The two strongest hypotheses for this behavior are increased protection from predators (predator-avoidance hypothesis) and greater resource abundance in early-successional forest (resource-selection hypothesis) (White et al. 2005). The thick understory associated with earlysuccessional habitats provides cover, which is of critical importance to fledglings that lack the knowledge to detect and escape predators and thus experience high mortality during the postfledging period (Anders et al. 1997). Moreover, adults may seek protection and cover during the post-breeding season as they undergo a pre-basic molt, making them temporarily more vulnerable to predators (Pagen et al. 2000). Post-fledging movements into habitat with dense understory were associated with increased survival for young Ovenbirds (King et al. 2006), even though prey abundance was low, lending support for the predator-avoidance hypothesis.

Abundant food resources are needed by hatch year birds for accumulation of fat reserves and completion of the first pre-basic molt (DeGraaf \& Yamasaki 2003). Adult passerines also experience a spike in energy demands during their pre-basic molt (Murphy \& King 1992). Molt is energetically demanding and requires additional energy and protein not only for synthesizing 
feathers, but also for increasing metabolism to offset poorer insulation and flight efficiency (Gill 1994). Trees and shrubs fruit earlier in young second growth forest than in mature forest in the summer (Vega Riviera et al. 1998) thus providing increased food resources in shrublands relative to other forest habitats. White et al. (2005) found support for the resource-selection hypothesis. They tracked juvenile Swainson's Thrushes (Catharus ustulatus) in California during the postfledging period into habitats not used by breeding adults, including coastal scrub. Swainson's Thrush habitat use was best explained by fruit abundance variables.

For some species, movement to habitats that differ from their natal territories may be driven by avoidance of intraspecific competition (Anders et al. 1998; Vega Rivera et al. 1998). Another suggestion is that adults are forcing young birds out of their territories. However, this situation is not likely since adults and family groups have been observed frequently in earlysuccessional habitat. Other alternative hypotheses that have not gained support include searching for a future breeding site, migration commencement, and socialization with conspecifics (Vega Rivera et al. 1998; White et al. 2005). A final explanation is that the birds are exhibiting "passive dispersal;" i.e., they use these habitats because they cross them as they move through the forest, although there has been no research to support this (Anders et al. 1998; Vega Rivera et al. 1999; Pagen et al. 2000).

Adults of some species have been captured in early-successional habitat during the breeding season such as the Ovenbird, Kentucky Warbler, and Worm-eating Warbler (Pagen et al. 2000). Most of these birds did not sing and were likely to either be floaters or territorial males foraging in these habitats. Thus, some bird species are not constrained by nesting requirements in terms of breeding bird habitat use (Pagen et al. 2000). These incidences of occurrence during the breeding period suggest that regenerating harvests may be important habitat not only for early-successional breeding species, but also for mature-forest breeders as non-nesting habitat.

Because both adults and juveniles of several species with a variety of habitat preferences use these young regenerating stands during the post-breeding period, the quality of this habitat is an important consideration. Despite a wealth of data showing that birds are concentrated in early-successional habitat after breeding, habitat use does not necessarily imply habitat quality. Researchers should gather survival data and address the differences between early-successional habitat used and that which is avoided to discover any patterns that could explain bird behavior 
and habitat use during this period. Also, post-breeding edge sensitivity of mature-forest birds and their early-successional counterparts should be further explored (Rodewald \& Vitz 2005).

\section{Mist-netting as a post-breeding sampling technique}

The post-breeding period is one of the most difficult parts of the avian life cycle to study due to the birds' silent and secretive nature as well as a tendency to move far from the natal site (Baker 1993). Surveying by vision may be difficult because birds often forage in dense vegetation. Consequently mist-netting may be one of the most reliable methods for sampling birds in this period (Ralph et al. 2004). Furthermore, as most vegetation in young regenerating stands is near the height of a standard mist-net, mist-netting is an effective choice for sampling birds in this low vertical structure (Pagen et al. 2000).

In general, mist-nets are a useful tool for collecting standardized data on relative abundance, species composition, and demographics (Nur et al. 1999; Ralph et al. 2004). Some other advantages of this method are a reduction in observer-related biases and rapid accumulation of standardized samples (Karr 1981). However, there are a few biases associated with this method such as interspecific and intraspecific differences in capture probability due to mean flight and flight frequency differences, differences in net location, variability in net tension, and variability in microclimate differences for each net (Remsen \& Good 1996).

Mist-net capture rates are a form of relative population estimates. For instance, adult capture rates have been used as an index of abundance (Chase et al. 1997; Silkey et al. 1999). In one instance, mist-net capture rates of Wilson's Warblers (Wilsonia pusilla) corresponded with abundance estimates from spot-mapping (Chase et al. 1997). However, relative abundances should not be compared among species or age classes because of different capture probabilities. Species composition is assessed by determining species richness and diversity from captures. Finally, annual adult survival and productivity estimates may be attained with adequate sample sizes (Ralph et al. 2004).

\section{Productivity indices from mist-net data}

The relative proportion of juveniles: adults after the fledging period has often been used as an index of reproductive effort (Karr 1981). Probability of capture for hatch year (HY) and after hatch year (AHY) birds varies for each species; therefore, the ratio is not usually a reliable 
estimate of actual productivity. HY birds are often more susceptible to mist-net captures. However, when comparing samples from different sites, the ratio is an index of productivity in a spatial or temporal sense.

Nest monitoring by Bollinger and Linder (1994) supported evidence that HY:AHY ratios are a useful comparison of relative productivity, and Kirtland's Warbler (Dendroica kirtlandii) productivity estimated by surveys was strongly correlated with the HY:AHY index (Bart et al. 1999). Productivity indices have been linked to adult bird abundance the following year (Johnson \& Geupel 1996; Chase et al. 1997). Additionally, the number of hatch year birds per net hour has been used as an index of production of young at a population-level (Desante \& Geupel 1987; Chase et al. 1997; Nur et al. 1999). Finally, the productivity ratios may be compared to average ratios from nearby MAPS or other banding stations for individual species.

\section{Study Area}

The study was conducted primarily within the Monongahela National Forest (MNF) in Pocahontas, Randolph, and Tucker Counties, and the MeadWestvaco Wildlife and Ecosystem Research Forest (MWERF) in Randolph County, West Virginia (Figure 2). The forests, both actively managed for timber harvesting, are located in the Allegheny Mountains region of the Appalachians and are characterized by narrow, low valleys dissected by northeast-southwest ridges. Elevations of the study site ranged from 550 to $1,150 \mathrm{~m}$. The landscape is $80-90 \%$ forested, and the MWERF has a higher percentage of recent harvests.

Dominant tree species in the study stands included black cherry (Prunus serotina), black birch (Betula lenta), yellow-poplar (Liriodendron tulipifera), sugar maple (Acer saccharum), red maple (A. rubrum), white ash (Fraxinus americana), and fire cherry (Prunus pensylvanica) (Nichols 1996). Red oak (Quercus rubra), American beech (Fagus grandifolia), and yellow birch (B. alleghaniensis) were other important components of the overstory in the study stands. The principal forest types were northern Allegheny hardwoods (MWERF and MNF), cove hardwoods (MWERF and MNF), and oak-hickory (MNF). Eastern hemlock (Tsuga canadensis) and rhododendron (Rhododendron spp.) were dominant on high elevation ridges and along riparian areas. The most abundant regenerating understory plants were blackberries (Rubus spp.), black birch (Betula lenta), greenbrier (Smilax spp.), American beech, maples, and yellow poplar. 
The breeding bird study (chapter 2) used five treatments (represented by 29 stands): mature second growth forest $>80$ years without major disturbance (unharvested treatment), 1926 year old clearcut and two-age stands, and recently harvested clearcut and two-age stands (610 years old at study initiation). Size of harvests ranged from 3.6-20 ha. I selected 13 stands for the post-breeding study (chapters 3 and 4) consisting of three treatments: clearcut (few or no residual trees), low-leave two-age (2.0-3.7 $\mathrm{m}^{2} /$ ha retained basal area), and high-leave two-age (5.3-7.0 $\mathrm{m}^{2} /$ ha retained basal area) (Figure 3).

\section{Literature Cited}

Anders, A. D., D. C. Dearborn, J. Faaborg, and F. R. Thompson III. 1997. Juvenile survival in a population of Neotropical migrant birds. Conservation Biology 11:698-707.

Anders, A. D., J. Faaborg, and F. R. Thompson, III. 1998. Postfledging dispersal, habitat use, and home-range size of juvenile Wood Thrushes. Auk 115:349-358.

Annand, E. M., and F. R. Thompson III. 1997. Forest bird response to regeneration practices in Central hardwood forests. Journal of Wildlife Management 61:159-171.

Askins, R. A., J. F. Lynch, and R. Greenberg. 1990. Population declines in migratory birds of eastern North America. Current Ornithology 7:1-57.

Baker, R. R. 1993. The function of post-fledging exploration: a pilot study of three species of passerines ringed in Britain. Ornis Scandinavica 24:71-79.

Baker, M. D., and M. J. Lacki. 1997. Short-term changes in bird communities in response to silvicultural prescriptions. Forest Ecology and Management 96:27-36.

Bart, J., C. Kepler, P. Sykes, and C. Bocetti. 1999. Evaluation of mist-net sampling as an index to productivity in Kirtland's Warblers. Auk 116:1147-1151.

Bollinger, E. K., and E. T. Linder. 1994. Reproductive success of Neotropical migrants in a fragmented Illinois forest. Wilson Bulletin 106:46-54.

Boardman, L. A., and R. H. Yahner. 1999. Wildlife communities associated with even-aged reproduction stands in two state forests of Pennsylvania. Northern Journal of Applied Forestry 16:89-95.

Bourque, J., and M.-A. Villard. 2001. Effects of selection cutting and landscape-scale harvesting on the reproductive success of two Neotropical migrant bird species. Conservation Biology 15: 184-195. 
Brawn, J. D., S. K. Robinson, and F. R. Thompson III. 2001. The role of disturbance in the ecology and conservation of birds. Annual Review of Ecology and Systematics 32:251-276.

Chambers, C. L., W. C. McComb, and J. C. Tappeiner II. 1999. Breeding bird responses to three silvicultural treatments in the Oregon Coast Range. Ecological Applications 9:171-185.

Chase, M. K., N. Nur, and G. R. Geupel. 1997. Survival, productivity, and abundance in a Wilson's warbler population. Auk 114:356-366.

Cody, M. L. 1981. Habitat selection in birds: the roles of vegetation structure, competitors, and productivity. BioScience 31:107-113.

Costello, C. A., M. Yamasaki, P. J. Pekins, W. B. Leak, and C. D. Neefus. 2000. Songbird response to group selection harvests and clearcuts in a New Hampshire northern hardwood forest. Forest Ecology and Management 127:41-54.

DeGraaf, R. M., W. M. Healy, and R. T. Brooks. 1991. Effects of thinning and deer browsing on breeding birds in New England USA oak woodlands. Forest Ecology and Management 41:179-192.

DeGraaf, R. M., and M. Yamasaki. 2003. Options for managing early-successional forest and shrubland bird habitats in the northeastern United States. Forest Ecology and Management 185:179-191.

Desante, D. F., and G. R. Geupel. 1987. Landbird productivity in Central coastal California: the relationship to annual rainfall, and a reproductive failure in 1986. Condor 89:636-653.

Donovan, T. M., P. W. Jones, E. M. Annand, and F.R. Thompson III. 1997. Variation in localscale edge effects on cowbird distribution and nest predation. Ecology 78:2064-2075.

Duguay, J. P., P. B. Wood, and G.W. Miller. 2000. Effects of timber harvests on invertebrate biomass and avian nest success. Wildlife Society Bulletin 28:1123-1131.

Duguay, J. P., P. B. Wood, and J.V. Nichols. 2001. Songbird abundance and avian nest survival rates in forests fragmented by different silvicultural treatments. Conservation Biology 15:14051415 .

Fink, A. D., F. R. Thompson III, and A. A. Tudor. 2006. Songbird use of regenerating forest, glade, and edge habitat types. Journal of Wildlife Management 70:180-188.

Gill, F. B. 1994. The annual cycles of birds. Pages 263-285 in Ornithology. $2^{\text {nd }}$ edition. W. H. Freeman, New York. 
Gram, W. K., P. A. Porneluzi, R.L. Clawson, J. Faaborg, and S.C. Richter. 2003. Effects of experimental forest management on density and nesting success of bird species in Missouri Ozark Forests. Conservation Biology 17:1324-1337.

Hagan III, J. M., M. Vander Haegen, and P. S. McKinley. 1996. The early development of forest fragmentation effects on birds. Conservation Biology 10:188-202.

Hunter, M. L., Jr. 1990. Wildlife, forests and forestry: Principles of managing forests for biological diversity. Prentice Hall, Englewood Cliffs, New Jersey. 370 pp.

Hunter, W. C., D. A. Buehler, R. A. Canterbury, J. L Confer, and P. B. Hamel. 2001. Conservation of disturbance-dependent birds in eastern North America. Wildlife Society Bulletin 29:440-455.

Jobes, A. P., E. Nol, and D. R. Voigt. 2004. Effects of selection cutting on bird communities in contiguous eastern hardwood forests. Journal of Wildlife Management 68:51-60.

Johnson, M. D., and G. R. Geupel. 1996. The importance of productivity to the dynamics of a Swainson's thrush population. Condor 98:133-141.

Karr, J. R. 1981. Surveying birds with mist nets. Pages 62-67 in C.J. Ralph and J.M. Scott, editors. Estimating numbers of terrestrial birds. Studies in Avian Biology 6.

King, D. I., C. R. Griffin, and R. M. DeGraaf. 1996. Effects of clearcutting on habitat use and reproductive success of the Ovenbird in forested landscapes. Conservation Biology 10:13801386.

King, D. I., and R. M. DeGraaf. 2000. Bird species diversity and nesting success in mature, clearcut and shelterwood forest in northern New Hampshire, USA. Forest Ecology and Management 129:227-235.

King, D. I., R. M. DeGraaf, and C. R. Griffin. 2001. Productivity of early successional shrubland birds in clearcuts and groupcuts in an Eastern deciduous forest. Journal of Wildlife Management 65:345-350.

King, D. I, R. M. Degraaf, M. L. Smith, and J. P. Buonaccorsi. 2006. Habitat selection and habitat-specific survival of fledgling Ovenbirds (Seiurus aurocapilla). Journal of Zoology 269:414-421.

Krementz, D. G., and J. S. Christie. 2000. Clearcut stand size and scrub successional bird assemblages. Auk 117:913-924.

Lorimer, C. G. 1989. Relative effects of small and large disturbance on temperate hardwood forest structure. Ecology 70:565-567. 
Manolis, J. C., D. E. Andersen, and F. J. Cuthbert. 2002. Edge effect on nesting success of ground nesting birds near regenerating clearcuts in a forest-dominated landscape. Auk 119:955970.

Marshall, M. R., J. A. Dececco, A. B. Williams, G. A. Gale, and R. J. Cooper. 2003. Use of regenerating clearcuts by late-successional bird species and their young during the post-fledging period. Forest Ecology and Management 183:127-135.

Maurer, B. A., L. B. McArthur, and R. C. Whitmore. 1981. Effects of logging on guild structure of a forest bird community in West Virginia. American Birds 35:11-13.

Miller, G. W., P. B. Wood, and J. V. Nichols. 1995. Two-aged silviculture: an innovative tool for enhancing species diversity and vertical structure in Appalachian hardwoods. Forest health through silviculture. Proceedings of the 1995 National Silviculture Workshop.

Miller, G. W., J. N. Kochenderfer, and D. Fekedulegn. 2004. Composition and development of reproduction in two-Age Appalachian hardwood stands: 20-year results. Silviculture in special places: Proceedings of the National Silviculture Workshop.

Murphy, M. E., and J. R. King. 1992. Energy and nutrient use during moult by white-crowned sparrows, Zonotrichia leucophrys gambelii. Ornis Scandinavica 23:304-313.

Nichols, J. V. 1996. Effects of two-age timber management and clearcutting on songbird density and reproductive success. M.S. Thesis. West Virginia University, Morgantown, West Virginia.

Nur, N., S. L. Jones, and G. R. Geupel. 1999. A statistical guide to data analysis of avian monitoring programs. U.S. Department of the Interior, Fish and Wildlife Service, BTP-R60011999. Washington, D.C.

Pagen, R. W., F. R. Thompson III, and D.E. Burhans. 2000. Breeding and post-breeding habitat use by forest migrant songbirds in the Missouri Ozarks. Condor 102:738-747.

Paton, P. W. C. 1994. The effect of edge on avian nest success: how strong is the evidence? Conservation Biology 8:17-26.

Perkey, A. W., G. W. Miller, and T. M. Schuler. 1999. Regeneration results using two-aged management. Forest Management Update 19:1-9.

Ralph, C. J., E. H. Dunn, W. J. Peach, and C. M. Handel. 2004. Recommendations for the use of mist nets for inventory and monitoring of bird populations. Pages 187-196 in C.J. Ralph and E.H. Dunn, editors. Monitoring bird populations using mist nets. Studies in Avian Biology 29.

Rappole, J. H., and K. Ballard. 1987. Postbreeding movements of selected species of birds in Athens, Georgia. Wilson Bulletin 99:475-480. 
Remsen, J. V. Jr. and D. A. Good. 1996. Misuse of data from mist-net captures to assess relative abundance in bird populations. Auk 113:381-398.

Robbins, C. S., J. R. Sauer, R. S. Greenberg, and S. Droege. 1989. Population declines in North American birds that migrate to the Neotropics. Proceedings of the National Academy of Science (USA) 86:7658-7662.

Robinson, W. D., and S. K. Robinson. 1999. Effects of selective logging on forest bird populations in a fragmented landscape. Conservation Biology 13:58-66.

Rodewald, A. D., and A. C. Vitz. 2005. Edge- and area-sensitivity of shrubland birds. Journal of Wildlife Management 69:681-688.

Ross, B. 2001. Breeding bird productivity in forestlands of Northeastern Pennsylvania. Technical Bulletin No. 0821. Research Triangle Park, NC: National Council for Air and Stream Improvement.

Rudnicky, T. C., and M. L. Hunter, Jr. 1993. Reversing the fragmentation perspective: effects of clearcut size on bird species richness in Maine. Ecological Applications 3:357-366.

Sallabanks, R., E. B. Arnett, and J. M. Marzluff. 2000. An evaluation of research on the effects of timber harvest on bird populations. Wildlife Society Bulletin 28:1144-1155.

Sauer, J. R., J. E. Hines, and J. Fallon. 2005. The North American Breeding Bird Survey, Results and Analysis 1966 - 2005. Version 6.2.2006. USGS Patuxent Wildlife Research Center, Laurel, Maryland.

Silkey, M., N. Nur, and G. R. Geupel. 1999. The use of mist-net capture rates to monitor annual variation in abundance: a validation study. Condor 101:288-298.

Smith, H. C., N. I. Lamson, and G. W. Miller. 1989. An esthetic alternative to clearcutting? Journal of Forestry 87:14-18.

Smith, D. M., B. C. Larson, M. J. Kelty, and P. M. S. Ashton. 1997. The practice of silviculture: applied forest ecology. John Wiley \& Sons, Inc., New York.

Stuart-Smith, A. K., and J. P. Hayes. 2003. Influence of residual tree density on predation of artificial and natural songbird nests. Forest Ecology and Management 183:159-176.

Thompson, F. R., W. D. Dijak, T. G. Kulowiec, and D. A. Hamilton. 1992. Breeding bird populations in Missouri Ozark forests with and without clearcutting. Journal of Wildlife Management 56:23-30.

Vega Rivera, J. H., J. H. Rappole, W. J. McShea, and C. A. Haas. 1998. Wood Thrush postfledging movements and habitat use in northern Virginia. Condor 100:69-78. 
Vega Rivera, J. H., W. J. McShea, J. H. Rappole, and C. A. Haas. 1999. Postbreeding movements and habitat use of adult Wood Thrushes in northern Virginia. Auk 116: 458-466.

Vega Rivera, J. H., W. J. McShea, and J. H. Rappole. 2003. Comparison of breeding and postbreeding movements and habitat requirements for the Scarlet Tanager (Piranga olivacea) in Virginia. Auk 120:632-644.

Vitz, A. C., and A. D. Rodewald. 2006. Can regenerating clearcuts benefit mature-forest songbirds? An examination of post-breeding ecology. Biological Conservation 127:477-486.

Weakland, C. A. 2000. Songbird response to diameter-limit and two-aged timber harvesting on an industrial forest in central West Virginia. Ph.D. dissertation. West Virginia University, Morgantown, West Virginia.

Welsh, C. J., and W. M. Healy. 1993. Effect of even-aged timber management on bird species diversity and composition in northern hardwoods of New Hampshire. Wildlife Society Bulletin 21:143-154.

White, J. D., T. Gardali, F. R. Thompson III, and J. Faaborg. 2005. Resource selection by juvenile Swainson's Thrushes during the postfledging period. Condor 107:338-401.

Whitman, A. A., J. M. Hagan III, and N. V. L. Brokaw. 1998. Effects of selection logging on birds in northern Belize. Biotropica 30:449-457.

Wilcove, D. S. 1988. Forest fragmentation as a wildlife management issue in the eastern United States. Pages 146-150 in Healthy forests, healthy world: proceedings of the 1988 Society of American Foresters national convention. Rochester, New York.

Yahner, R. H. 2000. Long-term effects of even-aged management on bird communities in Pennsylvania. Wildlife Society Bulletin 28:1102-1110. 


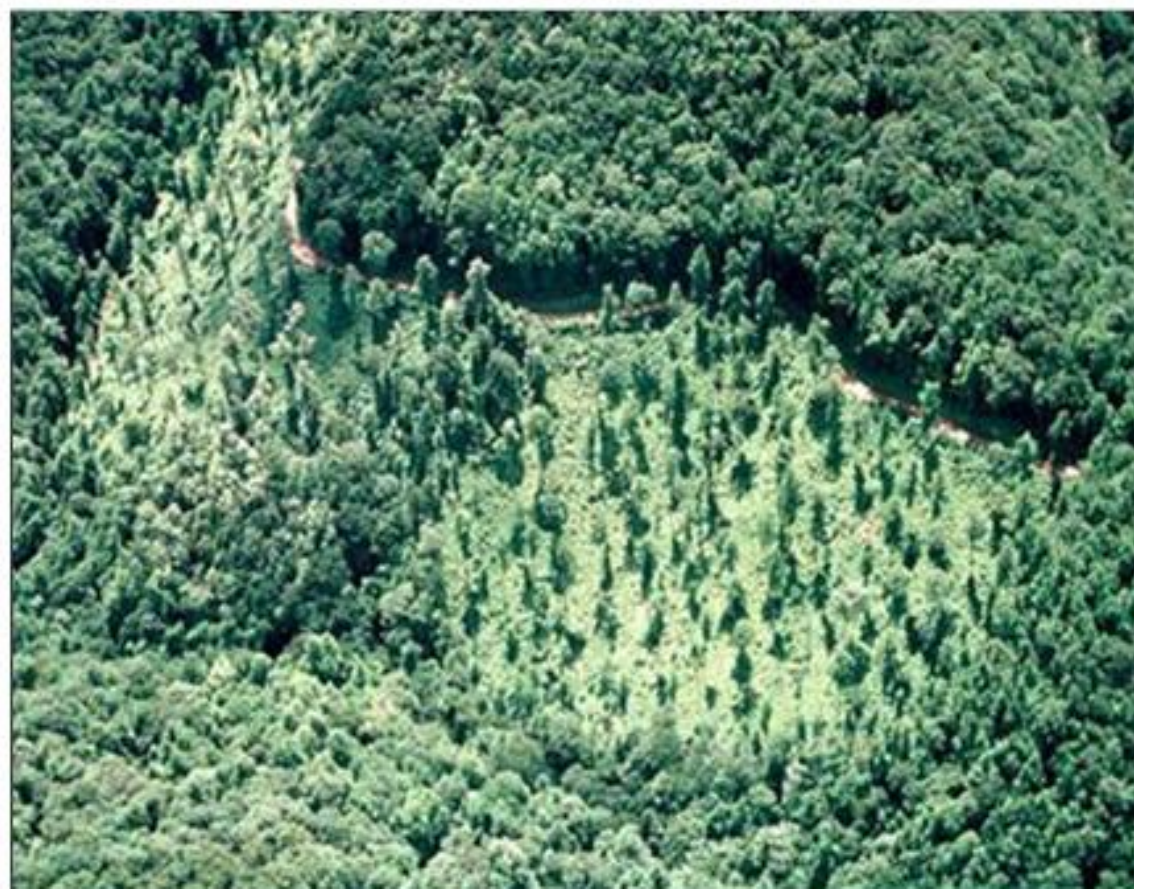

Figure 1. Aerial view of a two-age stand on the Fernow Experimental Forest 3 years postharvest in Parsons, West Virginia. Residual trees were 83 years old. Photo taken by J.N. Kochenderfer in 1984.
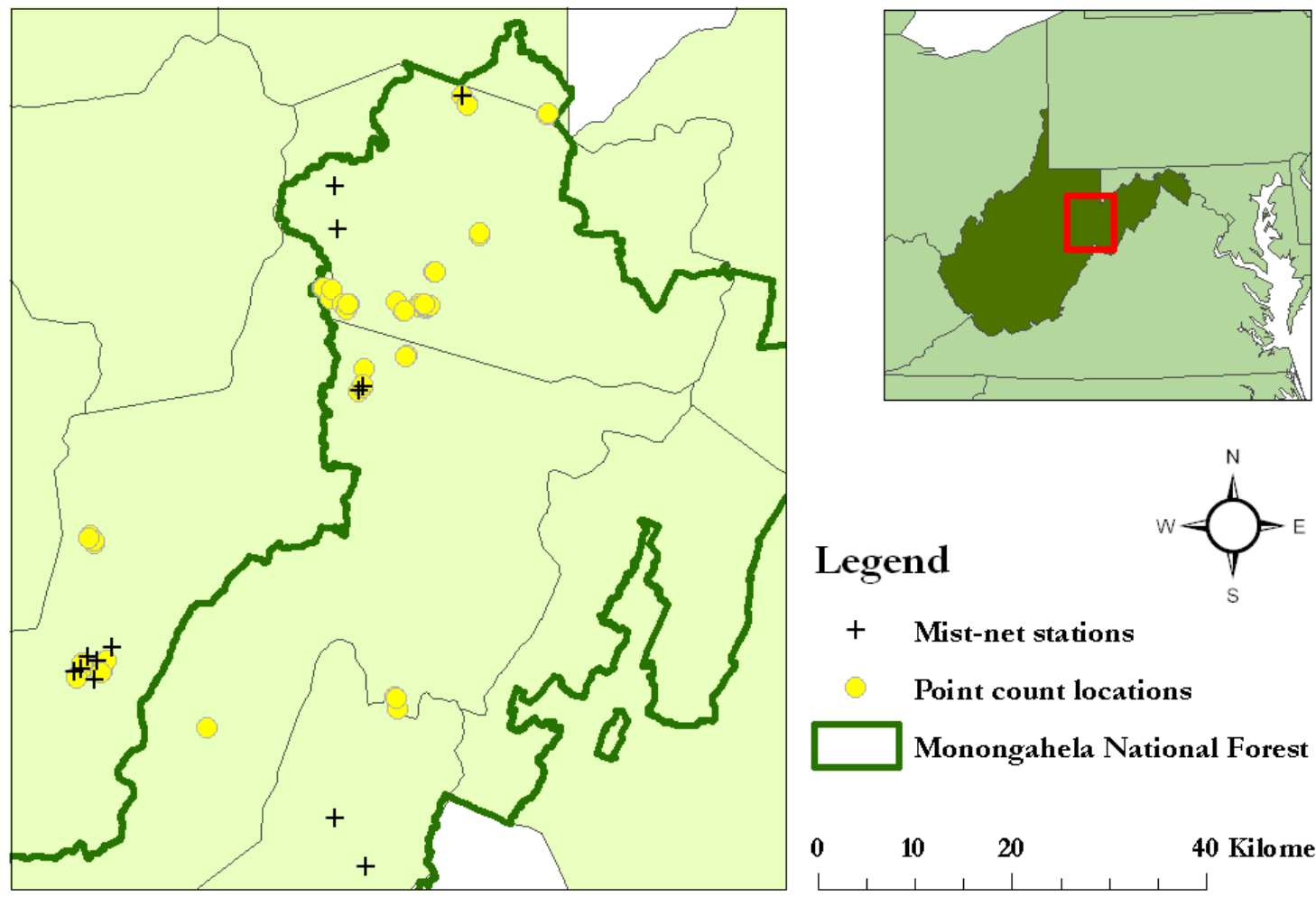

Legend

$+\quad$ Mist-net stations

Point count locations

$\square$ Monongahela National Forest

$0 \quad 10 \quad 20 \quad 40$ Kilometers

Figure 2. Location of study sites in West Virginia. Point count and mist-net stands outside of the Monongahela National Forest boundary were located on MeadWestvaco property. 

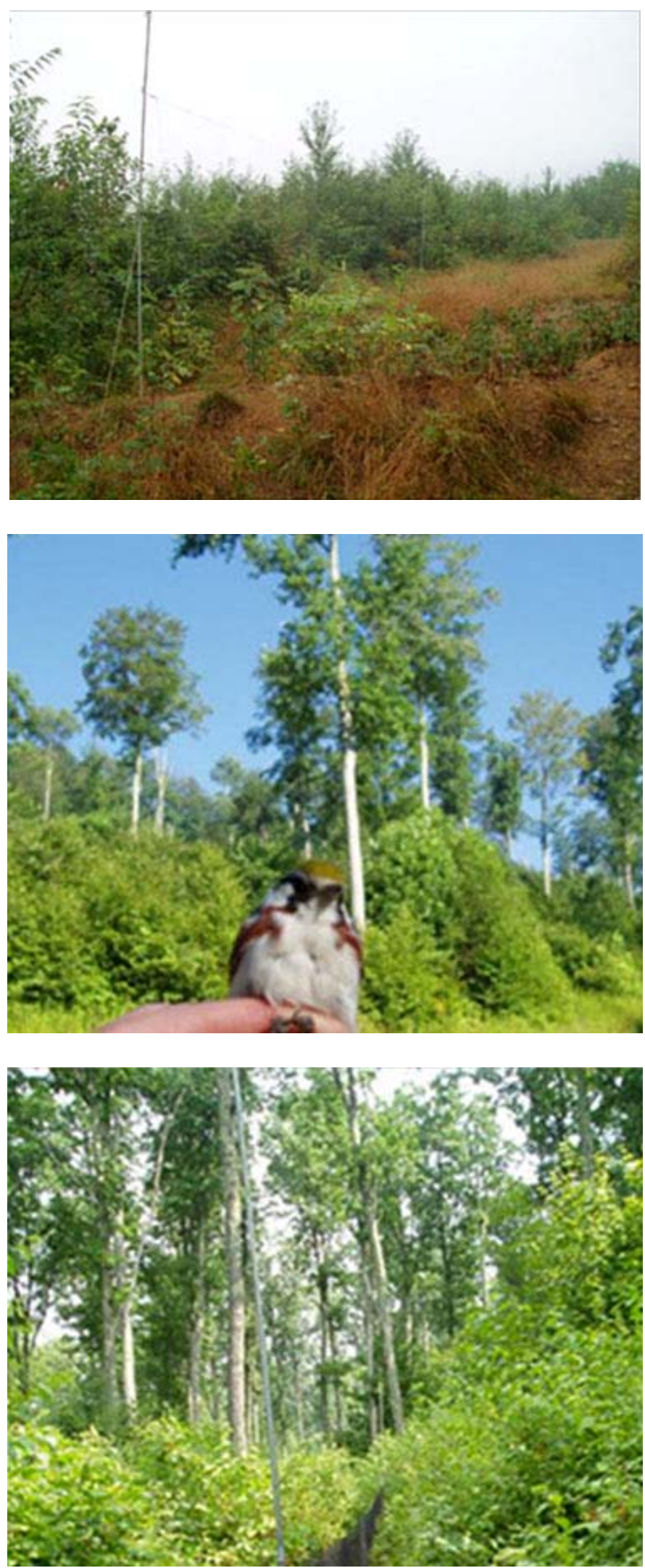

Figure 3. Clearcut (top), low-leave two-age (middle; pictured is a Chestnut-sided Warbler captured in this stand), and high-leave two-age (bottom) treatments used in post-breeding study. 


\section{Chapter 2}

\section{Short- and long-term implications of clearcut and two-age silviculture for forest breeding bird conservation}

Formatted in the style of Conservation Biology 


\begin{abstract}
Two-age harvesting has been given increased consideration in the management of Central Appalachian hardwood stands, but long-term responses of avifauna to these harvests have not been investigated. I examined the effects of clearcut and two-age harvesting on breeding bird relative abundance and species composition in West Virginia. Breeding bird surveys completed in 1994-1996, about 10 years prior to my study, provided an opportunity to document long-term changes in stands harvested by these methods. In 2005 and 2006, I conducted point counts in mature unharvested forest, clearcut and two-age harvests from the original study (19-26 years old), and younger clearcut and two-age stands (6-10 years old). I found differences in breeding bird metrics among these five treatments and temporal differences comparing time periods in the old harvests and unharvested stands. Relative abundance of early-successional breeding species was similar in young two-age stands and young clearcuts. Many of these species, which are typically absent from group selection cuts, were present in two-age stands thus supporting their promise as an alternative to clearcutting. Although the older harvests had lower overall relative abundance, species richness, and diversity, they provided habitat for Neotropical migrant mature forest songbirds that were absent or uncommon in the young harvests, and several latesuccessional species became more common in the older harvests over the 10 year period between studies. Consequently, two-age management provides habitat for a diverse group of species assemblages as these stands mature and may be an ecologically sustainable alternative to clearcutting in landscapes where Brown-headed Cowbirds (Molothrus ater) are uncommon.
\end{abstract}




\section{Introduction}

A balance of disturbance levels is needed to maintain avian biodiversity in forested landscapes (Hagan et al. 1997; Hunter et al. 2001), and more research is needed to determine if forest management can simultaneously create habitat for both early-successional and mature forest species. Timber harvesting may represent a loss of habitat for area-sensitive forest-interior species of birds that require large tracts of unfragmented mature forest to breed (Wilcove 1988; Thompson et al. 1992; Welsh \& Healy 1993). Conversely, silvicultural treatments that create openings or patches of young forest are valuable to early-successional species (DeGraaf \& Yamasaki 2003; Gram et al. 2003; Yahner 2003). Consequently, forest management may be an important tool for mimicking the natural disturbances necessary to support these species, many of which have lost habitat in recent years due to forest maturation and farm abandonment in the northeastern United States (Litvaitis 1993; Brawn el al. 2001).

Clearcutting is a widely used even-aged silvicultural technique that removes the entire overstory in one harvest (Smith et al. 1997). There has been widespread public disapproval of the appearance of clearcuts immediately after harvest (Costello et al. 2000; Miller et al. 2006), concern about hydrological impacts and other forest health issues (Costello et al. 2000), and concern about edge and fragmentation effects that may contribute to regional avian population declines (Wilcove 1988). However, silvicultural clearcutting that mimics the frequency and scale of natural disturbances is an efficient means for providing habitat for early-successional species (Annand \& Thompson 1997; Brawn et al. 2001; DeGraaf \& Yamasaki 2003; Fink et al. 2006). Although selection harvesting was proposed as a compromise between habitat needs of mature forest and early-successional species, recent studies have shown that openings created by this technique are not large enough to provide habitat for some early-successional breeders (Annand \& Thompson 1997; Robinson \& Robinson 1999; Costello et al. 2000; King et al. 2001).

Two-age harvesting, proposed as an alternative to mitigate ecological effects of clearcutting and improve aesthetics, is being increasingly used in management of Central Appalachian hardwood forests (Smith et al. 1989; Miller et al. 1995). During a two-age harvest, approximately 25-50 residual canopy trees are left per ha, and all other stems greater than $2.5 \mathrm{~cm}$ in diameter are cut (Smith et al. 1989). A dominant mature age class of residual trees and a regenerating age class result from the harvest; residual trees remain until the next rotation. The resultant vertical stratification provides habitat for both shrub and canopy-foraging species 
(Chambers et al. 1999), and two-age harvests have additional conservation benefits for wildlife by retaining mast-producing trees that also serve as nesting and foraging substrates and singing perches (Boardman \& Yahner 1999; Duguay et al. 2000). Furthermore, regeneration in two-age harvests is similar to that of clearcuts with stands containing both shade-tolerant and -intolerant tree species important for maintaining stand diversity (Smith et al. 1989; Perkey et al. 1999; Miller et al. 2006).

Several studies have documented the short-term effects of two-age harvests on breeding birds. In general, breeding bird metrics such as total bird abundance and diversity increase in two-age stands (Baker \& Lacki 1997; Boardman \& Yahner 1999). Early-successional species thrive immediately after harvest (Baker \& Lacki 1997; Boardman \& Yahner 1999). Moreover, many mature forest species have been documented using two-age stands (Boardman \& Yahner 1999; Duguay et al. 2001). Harvests with residual trees tend to ameliorate the effects of clearcutting in the short-term for some mature forest species (Tittler et al. 2001). In West Virginia, nest survival was greater in two-age stands immediately post-harvest compared to unharvested stands (Weakland 2000). Brown-headed Cowbirds (Molothrus ater) increased significantly in two-age harvests within agriculture-dominated landscapes (Baker \& Lacki 1997), but in extensively forested areas, cowbird parasitism is low and therefore less of a concern (Chambers et al. 1999; Weakland 2000; Duguay et al. 2001).

The Monongahela National Forest and Northeastern Research Station are cooperating to study the effects of two-age harvests from a silvicultural perspective (Miller et al. 2006). From 1979 to 1984, a type of two-age harvest was applied to mature, second-growth Appalachian hardwood forests. Duguay et al. (2001) examined breeding bird abundance and nest survival from 1993 to 1996 in these two-age stands, similarly-aged clearcuts (approximately 10-15 years old), and unharvested stands. Songbird densities were slightly higher in two-age cuts than clearcuts, but not significantly so. Species associated with early-successional or edge habitat were more common in two-age stands. But more forest-interior breeding birds occurred in unharvested stands where nest survival was highest. Nest parasitism rates by Brown-headed Cowbirds were low, but associated with the two-age treatment, further signifying that two-age harvesting may not be appropriate in landscapes where cowbirds are abundant.

These studies have provided insights into the effects of two-age harvesting on breeding birds in the short term, but no studies have examined bird communities in two-age stands beyond 
15 years post-harvest, and little knowledge of how these communities change over time as vegetative structure changes. Long-term studies focusing on the effects of forest management on wildlife are uncommon, and in particular, studies of long-term effects of residual tree retention on breeding birds are needed (Tittler et al. 2001). Additionally, more knowledge is needed about the potential of two-age harvests for providing habitat for early-successional species, many of which are of high conservation concern (Brawn et al. 2001; Panjabi et al. 2005).

I investigated breeding bird population response to clearcuts and two-age harvests to determine whether two-age management is a suitable alternative for conservation of mature forest and early-successional breeding birds. In 2005-2006, bird surveys were conducted in young stands 6-10 years post-harvest and in 19-26 year-old harvests and unharvested mature forest stands surveyed by Duguay et al. (2001). The study objectives were to (1) examine differences in breeding bird metrics (relative abundance and species composition) among treatments; (2) determine relative temporal changes in the bird communities by comparing current data to the data collected in 1994-1996 in the old harvests and mature forest (long-term treatment effects); and (3) quantify differences in vegetative structure and composition among treatments and time periods.

\section{Methods}

Study site

The study was conducted primarily within the Monongahela National Forest (MNF) in Pocahontas, Randolph, and Tucker Counties, and the MeadWestvaco Wildlife and Ecosystem Research Forest (MWERF) in Randolph County, West Virginia. The forests, both actively managed for timber harvesting, are located in the Allegheny Mountains region of the Appalachians and are characterized by narrow, low valleys dissected by northeast-southwest ridges. Elevations of the study sites ranged from 550 to $1,150 \mathrm{~m}$.

Dominant tree species in the study stands included black cherry (Prunus serotina), black birch (Betula lenta), yellow-poplar (Liriodendron tulipifera), sugar maple (Acer saccharum), red maple (A. rubrum), white ash (Fraxinus americana), and fire cherry (Prunus pensylvanica) (Nichols 1996). Red oak (Quercus rubra), American beech (Fagus grandifolia), and yellow birch (B. alleghaniensis) were other important components of the overstory in the study stands. The principal forest types were northern Allegheny hardwoods (MWERF and MNF), cove 
hardwoods (MWERF and MNF), and oak-hickory (MNF). Eastern hemlock (Tsuga canadensis) and rhododendron (Rhododendron spp.) were dominant on high elevation ridges and along riparian areas.

Five treatments were represented: mature second growth forest $>80$ years without major disturbance (unharvested treatment), 19-26 year old clearcut and two-age stands, and recently harvested clearcut and two-age stands (6-10 years old at study initiation). Point count stations were partitioned among 29 stands ( $n=48$ point count stations): six young clearcuts $(n=10)$, six young two-age harvests $(n=10)$, six old clearcuts $(n=8)$, five old two-age harvests $(n=8)$, and six unharvested mature stands $(n=12)$. Size of harvests ranged from 3.6-20 ha.

\section{Stand selection}

The original 17 survey stands were selected to minimize differences in harvest size, age, vegetation type, slope and aspect (Nichols 1996). Point count stations in these old stands were $250 \mathrm{~m}$ apart in unharvested stands and, when possible, in harvested stands that contained two points. In 2005 I placed point count stations in six young clearcuts and six young two-age stands, again attempting to minimize differences in size, age, and vegetation type. Stands were not randomly selected due to the limited number of harvests available on the forests. These point count stations in young stands were established at least $100 \mathrm{~m}$ from any edge (or as close to 100 $\mathrm{m}$ as possible in the smaller harvested stands), and multiple points within a stand were separated by at least $200 \mathrm{~m}$ (250 $\mathrm{m}$ in stands that were large enough). New point locations were created using a GIS, and points were located as close to the stand center as possible.

\section{Point count surveys}

Relative abundance and species composition of breeding birds were quantified using a fixed-radius point count method (Ralph et al. 1995). Between 21 May and 16 June of 2005 and 2006, points were surveyed twice: once by each of two skilled observers. The order in which points were visited varied each round to account for within-morning variability in bird detectability. We conducted surveys only in optimal weather (i.e., no high winds, heavy fog, or rain), began at sunrise and ended at approximately 10 AM.

We counted all individual birds detected by sight or sound within a 10 -minute period. Observations were separated into three segments of 3-, 2-, and 5-minutes (Ralph et al. 1995). Individual birds were recorded in bands of 25, 50, 100, and $>100 \mathrm{~m}$ to allow for comparisons 
with other studies. Prior to conducting point counts each spring, observers were trained in distance estimation and refreshed their bird identification skills. Simultaneous counts were performed at the beginning of each field season to strengthen observer consistency.

Data from Duguay et al. (2001) were collected via point counts from 1994-1996 using similar methods. The primary difference was that counts were completed in six instead of ten minutes; counts were separated into intervals were 3-, 2-, and 1-minutes). Comparisons between these datasets were based on five minute counts.

\section{Vegetation sampling}

As a study of different timber harvesting methods is in effect a study of the influence of vegetation structure on birds (Cody 1981; Maurer et al. 1981), I measured vegetative characteristics in each stand. Microhabitat characteristics were quantified using methods from the original study (Nichols 1996) that were modified from James and Shugart (1970). During July and August, I sampled vegetation at four 0.04 ha circular plots at each point count station. One plot was located at the point center, and the other three subplots were located $35 \mathrm{~m}$ from the point center at the directions $0^{\circ}, 120^{\circ}$, and $240^{\circ}$. I recorded species and diameter at breast height (dbh) of all trees and snags within each subplot for the following stem groups: seedlings and other stems $<2.5 \mathrm{~cm}$ dbh, saplings $2.6-7.6 \mathrm{~cm}$ dbh, poles $7.7 \mathrm{~cm}-15.2 \mathrm{~cm}$ dbh, trees $15.3-22.9$ $\mathrm{cm} \mathrm{dbh}$, trees 23-30.5 $\mathrm{cm}$ dbh, trees 30.6-38.1 $\mathrm{cm}$ dbh, and trees $>38.1 \mathrm{~cm} \mathrm{dbh}$.

Cover variables were recorded at five points spaced at $2.3 \mathrm{~m}$ intervals along $11.3 \mathrm{~m}$ transects extending in four cardinal directions from the center point (James and Shugart 1970). At each of the 20 sample points, I recorded with an ocular tube the presence or absence of the following cover variables: herbaceous ground, woody ground, bare or rocky ground, leaf litter, and canopy cover as five different layers: shrub (0-3 m), >3-6 m, >6-12 m, >12-18 m, >18-24 m, and $>24 \mathrm{~m}$. Percent ground and canopy cover layers were calculated by multiplying each presence record (20 maximum) by five. Vertical complexity of the vegetation was calculated as a combination of the number of canopy layers present and \% cover in each layer (Nichols 1996).

At each point count station, slope and aspect were measured in the field. Elevation was derived from a $30 \mathrm{~m}$ digital elevation model (DEM; West Virginia GIS Technical Center). 


\section{Data analyses}

All analyses were carried out using SAS statistical software (SAS Institute 2003). For all statistical tests, I used an a priori alpha level of 0.10 (instead of 0.05 ) to decrease the probability of committing a Type II error. This type of error may be more important to avoid than a Type I error, because failing to detect a significant response could result in the implementation of management practices that conflict with the needs of sensitive or declining species (Purcell et al. 2005).

\section{Breeding bird treatment effects}

Relative abundance was the maximum number of individuals detected over two visits in 2005 and 2006, because abundance and song frequency of most bird species varies throughout the breeding season. For multiple point count stations within a stand, I used the mean of the maximum number of individuals detected at each point. I included all observations within $50 \mathrm{~m}$ of each point. Species inadequately sampled by point counts (e.g., crows, ravens, gamebirds, and raptors) were omitted from analyses. Species richness and the Shannon diversity index were for each stand.

I also calculated relative abundance of breeding birds for habitat guilds (earlysuccessional, generalist, late-successional) and migratory guilds (Nearctic-Neotropical, shortdistance, and permanent resident). Birds were assigned to guilds based on Whitcomb et al. (1981), Ehrlich et al. (1988), and observations in West Virginia compiled from previous research (Appendix 1). Generalists were defined as those species that are not typically confined to earlyor late-successional habitat, may use a gradient of seral stages, and often breed in forest with an abundance of canopy gaps or open woods.

I compared breeding bird metrics among the five treatments: young clearcut, young twoage, old clearcut, old two-age, and unharvested. I chose analysis of variance (ANOVA), which is robust to conditions of non-normality (Zar 1999), to analyze point count data. To detect differences among treatments, I used a two-way nested ANOVA with stand nested within treatment to detect effects of treatment, year, and treatment by year interactions on the dependent variables: relative abundance of each species and guild, species richness, and species diversity. I analyzed the relative abundances of each species detected at a minimum of $15 \%$ of stands. Treatment tests were adjusted to account for within treatment variability among stands by using 
this (stand nested within treatment) as the error term. Waller-Duncan k-ratio t-tests were used to find which treatments differed when the ANOVA was significant. When there was a significant treatment by year interaction, tests of treatment effects were run separately for each of the two years. Observer was included in preliminary analyses as another model effect, but the observer effect was not significant so it was omitted from subsequent analyses.

\section{Breeding bird temporal effects}

For temporal comparisons between the two studies, I compared bird metrics in the old harvests and unharvested stands between the two time periods (1994-1996 vs. 2005-2006). The two-age stands and clearcuts were 8-15 years post-harvest in 1994 and 19-26 years post-harvest in 2005. I compared the three treatments with a nested two-way ANOVA incorporating treatment and year effects and their interactions. The same dependent variables were used as in the preceding bird analyses. I then used ANOVA with planned orthogonal contrasts to evaluate differences between the two time periods for each of the three treatments.

Due to apparent biases in distance estimation among observers from the two time periods, I included all detections within $100 \mathrm{~m}$, rather than $50 \mathrm{~m}$, of the point center that were recorded as being in the stand. Thus, long-distance observations, which are more subject to detectability bias among habitat types, were avoided by using a fixed-radius (Petit et al. 1995) while still correcting the distance-detection bias that was evident within $50 \mathrm{~m}$, but not beyond. Additionally, only observations within the first five minutes of each survey from either time period were included given that the duration of the counts was shorter in 1994-1996 (6 min vs. $10 \mathrm{~min}$ ). The $100 \mathrm{~m}$ method confers the benefit of increased statistical power by increasing the number of individual observations included in species analyses and compensating for those lost due to the shortened time interval.

\section{Vegetation analyses}

I also compared differences in vegetative habitat features among the treatments. A nested ANOVA compared habitat variables among the five treatments in 2005 and 2006. I then performed ANOVA with planned contrasts to compare vegetation changes over time in the three treatments sampled during both studies. Percentage variables (e.g., ground and canopy cover classes) were arcsine transformed and continuous variables were log-transformed to best 
approximate normality. Because of correlation among vegetation variables, I employed a Bonferroni correction procedure to reduce the probability of committing a Type I error (Sokal \& Rohlf 1995). This involved adjusting the significance level (0.10/number of tests).

\section{Results}

Breeding bird treatment effects

I detected 53 species within $50 \mathrm{~m}$ during point count surveys in 2005 and 2006. Thirty species were detected at a minimum of $15 \%$ of stands in at least one year (Table 1).

There was a significant treatment by year interaction for the analysis with relative abundance of all birds $\left(F_{4,25}=5.07, p=0.005\right)$. In 2005, the young clearcuts had the highest total bird abundance and old two-age stands had the lowest abundance, whereas in 2006 young two-age stands had the most individuals and unharvested stands had the fewest (Table 1). Species richness varied significantly among treatments. Mean total number of species per stand was significantly higher in young harvests (clearcut and two-age) and unharvested stands. Shannon diversity showed a similar pattern in which old two-age and clearcut stands had the lowest diversity. Clearcuts were more diverse than two-age stands, but not significantly. Old harvests consistently had the lowest species richness and diversity.

Relative abundance of early-successional breeding birds differed among the five treatments (Table 1). Individuals in this guild reached their greatest abundance in the young harvests, particularly in young clearcuts. Early-successional breeders were nearly absent from the old harvests and unharvested stands. Most early-successional species (e.g., Chestnut-sided Warbler (Dendroica pensylvanica), Eastern Towhee (Pipilo erythrophthalmus), and Indigo Bunting (Passerina cyanea)) were most abundant in young clearcuts and young two-age stands. No species was more common in stands with residual trees (two-age) compared to clearcuts.

Generalists were more common in young stands, but did not vary significantly among treatments (Table 1). Of generalists, the American Robin (Turdus migratorius), American Redstart (Setophaga ruticilla), and Red-eyed Vireo (Vireo olivaceus) reached their highest relative abundances in the old and unharvested stands. Conversely, the Hooded Warbler (Wilsonia citrina), Northern Flicker (Colaptes auratus), Rose-breasted Grosbeak (Pheucticus ludovicianus), and Veery (Catharus fuscescens) reached peak abundances in young stands. Thirty percent of generalist species were found in all treatments, and relative abundances of 
Cedar Waxwings (Bombycilla cedrorum), Wood Thrushes (Hylocichla mustelina), Dark-eyed Juncos (Junco hyemalis), and Black-capped Chickadees (Poecile atricapilla) did not vary among treatments. Canada Warblers (Wilsonia canadensis) were most likely to be found in young twoage stands and mature forest. Brown-headed Cowbird relative abundance did not differ significantly among treatments, but this species was most likely to be found in young two-age stands, and was nearly absent from the other treatments.

I detected a significant treatment by year interaction for relative abundance of latesuccessional breeding individuals $\left(F_{4,25}=4.34, p=0.01\right)$. In 2005, unharvested mature forest and old clearcuts had significantly more individuals than the other treatments (Table 1). In 2006, this guild was most abundant in unharvested and old two-age stands and least in young clearcuts. Differences in total bird abundance between years were most influenced by this guild. Relative abundances of late-successional breeders in the two-age stands (of both age classes) increased greatly in 2006. For this guild, typical patterns were shown by the Black-throated Blue Warbler (Dendroica caerulescens), Black-throated Green Warbler (Dendroica virens), Blue-headed Vireo (Vireo solitarius), Hairy Woodpecker (Picoides villosus), Winter Wren (Troglodytes troglodytes), and Acadian Flycatcher (Empidonax virescens, though non-significant), in which relative abundances were greatest in unharvested mature forest, followed by older stands. Many species were rare or absent in young stands. However, several showed no differences among treatments; e.g., the Scarlet Tanager (Piranga olivacea) and Magnolia Warbler (Dendroica magnolia). The Black-and-white Warbler (Mniotilta varia), was nearly absent from unharvested stands. This species was most frequently detected in young stands and old clearcuts.

\section{Vegetation treatment effects}

Nearly all vegetation variables except ground cover differed among the five treatments (Table 2). Canopy cover was highly variable among treatments and often with treatments. Shrub cover (0-3 m) was highest in young two-age stands and clearcuts, and lowest in the other three treatments. Canopy cover at a height of $>3-6 \mathrm{~m}$ varied similarly, except that old two-age and clearcut stands had more dense cover than unharvested stands. Old two-age and clearcut stands had the highest percentage of canopy cover at $>6-12 \mathrm{~m}$ and were similar to unharvested stands in terms of canopy cover at $>12-18 \mathrm{~m}$. Unharvested stands had by far the highest percentage of cover in the $>18-24 \mathrm{~m}$ and $>24 \mathrm{~m}$ categories. Two-age stands in each age group 
were similar to or had higher percentage canopy cover than clearcut stands of the same age group in all categories. Vertical complexity was greatest in the unharvested stands, intermediate in the two-age stands, and lowest in clearcuts, particularly the young clearcuts.

Two-age stands also surpassed clearcuts in basal area and stem density for all size classes of trees $>15.3 \mathrm{~cm}$ dbh (young stands) and all size classes of trees $>30.5 \mathrm{~cm}$ dbh (old stands; Table 2). Unharvested stands had the greatest number of stems for all tree classes except for trees 15.3-22.9 $\mathrm{cm}$ dbh. Old clearcuts and old two-age stands had the most trees in this category. Tree species richness was highest in unharvested stands, and the pattern among treatments followed that of total trees. For smaller stems $(<15.3 \mathrm{~cm})$, young stands dominated in totals, and clearcuts of both age classes had more stems than their respective two-age counterparts (although not statistically significant). Young two-age stands and clearcuts had substantially more stems $<$ $2.6 \mathrm{~cm}$ dbh compared to the other three treatments (also see shrub cover results above), but poles 7.7-15.2 cm dbh were most abundant in the old clearcuts and two-age stands. Species richness of stems $<15.3 \mathrm{~cm}$ dbh was highest in old clearcuts and both of the young treatments. Unharvested stands consistently had the most snags, but snag totals were low in all treatments.

\section{Breeding bird temporal effects}

Over the course of both studies, no significant differences were evident among the three treatments (unharvested, two-age, clearcut) in overall relative abundance, species richness, or species diversity except in 2005 (Appendix 2). In 2005-2006, all three metrics were lower in the two-age stands, and overall relative abundance was lower in unharvested stands (Table 3). These temporal decreases in abundance were reflected in declines of Nearctic-Neotropical migrants in both the two-age (39\%) and unharvested stands (31\%).

Early-successional species decreased in relative abundance over time in the harvest treatments ( $>90 \%$ decrease in two-age, $52 \%$ decrease in clearcut; Table 3 ). Of earlysuccessional breeders, only Indigo Buntings and Chestnut-sided Warblers, which used clearcut and two-age stands (respectively) most often, differed among treatments. But these patterns were not consistent across years (Appendix 2). Chestnut-sided Warblers and Eastern Towhees were largely absent from two-age stands in the latter years. Towhee relative abundance also decreased in clearcuts, and Indigo Bunting relative abundance declined in all treatments. 
Relative abundance for 7 of 21 generalists tested differed among treatments, although overall relative abundance of generalists did not (Table 3). Great Crested Flycatchers (Myiarchus crinitus), Red-eyed Vireos, and Tufted Titmice (Baeolophus bicolor) were consistently most abundant in clearcuts. Veeries were found in two-age and unharvested stands, but absent from clearcuts, in all years.

Generalist relative abundance decreased in both two-age and unharvested stands over time ( $\sim 30 \%$ decline in both treatments; Table 3$)$. Temporal changes in relative abundance occurred for several species. Blue Jays (Cyanocitta cristata) increased significantly in two-age stands and mature forest and American Robins increased by nearly five times in unharvested stands, while Veeries decreased in both two-age and unharvested stands by $~ 70 \%$. Dark-eyed Juncos increased in all treatments, significantly so in clearcuts and mature forest, while Wood Thrushes decreased in all treatments, significantly so in clearcuts (50\% decline) and mature forest (64\% decline). Northern Flickers, Red-bellied Woodpeckers (Melanerpes carolinus), and American Redstarts increased in clearcuts. Hooded Warbler and Rose-breasted Grosbeak relative abundance declined in both harvested treatments (64-100\% decrease). Brown-headed Cowbirds declined in all stands, but significantly in unharvested stands (by $88 \%$ ).

Late-successional breeders remained stable in all treatments, with no significant increases in the harvests over the 10 year period; this guild was always most abundant in unharvested stands (Table 3). Several late-successional species (e.g., Black-throated Blue Warblers, Blackthroated Green Warblers, Blue-headed Vireos, and Winter Wrens) consistently reached highest relative abundances in mature forest compared to the harvest treatments. However, Black-andwhite Warblers were more common in the harvest treatments in all years.

Over time, Acadian Flycatcher and Cerulean Warbler (Dendroica cerulea) relative abundance declined, but Blackburnian Warblers (Dendroica fusca) increased in unharvested stands. Black-throated Green Warblers and Blue-headed Vireos (although non-significant in clearcuts) doubled and tripled, respectively, in the harvested stands as they matured. Scarlet Tanager relative abundance increased three-fold in two-age stands. Eastern Wood-Pewees (Contopus virens) declined in all treatments, but not significantly in clearcuts. Magnolia Warblers and Ovenbirds (Seiurus aurocapillus) declined in clearcuts, where they were most abundant in 1994 and 1995 (Appendix 2), but remained stable in the other two treatments. 


\section{Vegetation temporal effects}

There were no differences in ground or shrub cover among the three treatments. Low canopy cover (> 3-6) was consistently greater in the clearcut and two-age stands (Table 4). In the $>12-18 \mathrm{~m}$ category, canopy cover was greater in unharvested stands from 1994-1996, but about equal among the three treatments in 2005 and 2006. Above $18 \mathrm{~m}$, canopy cover in unharvested stands was consistently greater; clearcuts had the least. Vertical complexity was greatest in unharvested stands, followed by two-age, and then clearcut; however, differences among the treatments lessened over time. Two-age stands had more sawtimber-sized trees than clearcuts throughout the study; the mature residual trees retained at harvest were still present. Unharvested stands had the lowest number of sapling and pole stems, but surpassed both harvest treatments in terms of all tree categories $\geq 30 \mathrm{~cm} \mathrm{dbh}$, even after 10 years of additional regeneration in the harvests. Unharvested stands had the greatest number of snags $>15.3 \mathrm{~cm}$ dbh. There were no differences in snags between clearcuts and two-age harvests.

Many habitat variables changed over the 10 year period (Table 4). Herbaceous ground cover decreased in all treatments, significantly so in two-age and unharvested stands, and woody ground cover decreased in all treatments. Shrub cover increased but canopy cover $>3-6 \mathrm{~m}$ decreased in clearcut stands. Canopy cover $>12-18 \mathrm{~m}$ increased in all three treatments. Clearcuts had increased canopy cover $>18-24 \mathrm{~m}$ and $>24 \mathrm{~m}$. Vertical complexity increased in all stands by 2005-2006, but this pattern was only statistically significant for clearcuts after the Bonferroni adjustment. Stem density of saplings $0-7.6 \mathrm{~cm}$ dbh decreased by $66 \%$ in clearcuts and $77 \%$ in two-age stands. Poles 7.7-15.2 cm dbh decreased in both clearcut and unharvested stands. Both clearcuts and two-age stands had more stems in all tree categories in 2005-2006, although not all increases were significant. The sum of all trees almost quadrupled in clearcuts and more than doubled in two-age harvests. Tree stem densities changed little in unharvested stands.

\section{Discussion}

In 2005 and 2006, there were no consistent differences between clearcut and two-age treatments (for either successional age) when considering total bird abundance, species richness, or diversity. However, the old harvests (19-26 years old) generally had the lowest values; thus, successional stage appeared to explain more variation in the data than type of harvest. This 
pattern of low relative abundance and diversity in pole-stage forest 20-30 years post-harvest is typical for harvested stands (Mitchell et al. 1991; Keller et al. 2003; Jobes et al. 2004). During this stage declines in avian populations may occur due to canopy closure, lack of structural heterogeneity, and loss of ground foraging and nesting sites (Keller et al. 2003).

Marked decreases occurred in relative bird abundance over the years in two-age and unharvested stands. This was mainly due to decreases in abundances of early-successional and generalist species in the old two-age stands and decreases in generalist abundance in unharvested stands. These species were mainly Nearctic-Neotropical migrants. Overall declines of this migratory guild in all three treatments may reflect regional declining trends for this group of birds in particular. In the Ridge and Valley physiographic region, Sauer et al. (2005) detected a decline over this period for the Indigo Bunting, an 8\% yearly decline for the Rose-breasted Grosbeak, a 5\% yearly decline for the Eastern Wood-Pewee, and a 2\% yearly decline for the Wood Thrush, all species that declined in all three treatments over the course of this study.

\section{Early-successional breeders}

Individuals of early-successional bird species used stands with fewer residual trees (young clearcuts), but were still found with some frequency in young two-age stands, suggesting that two-age harvesting creates temporary habitat for these species. The most notable features of these stands were high density of small stems (and consequent shrub cover up to $6 \mathrm{~m}$ ). Other than having fewer residual trees and lower vertical complexity in the clearcuts compared to the two-age harvests, these young treatments were not structurally different. Further, Duguay et al. (2001) found no significant differences in daily nest survival rates among clearcuts and two-age harvests for this guild. These species were uncommon in the 19-26 year old stands, suggesting that regardless of treatment, stands at this seral stage do not provide suitable habitat for earlysuccessional breeders. As expected, they were nearly absent from unharvested stands.

Relative abundance of early-successional breeders declined significantly in both harvested treatments. Thus, within a short time interval of 10 years, the harvests no longer provided suitable habitat for these birds, which confirms the pattern detected in comparisons of young vs. old stands from 2005-2006. The old two-age stands were harvested on average later than the clearcut stands and may not have had as much regeneration and thinning of the understory, thus explaining why some early-successional species were more abundant in two-age 
compared to clearcut stands in the early years (1994-1996). Vegetation measurements support this theory: shrub cover and understory stem densities were greater in two-age stands compared to clearcuts in 1994-1996.

Many early-successional bird species are facing serious declines and require management attention in the Central Appalachians (Brawn et al. 2001; Panjabi et al. 2005; Sauer et al. 2005). Several of the species I detected have experienced significant declining trends over the last 40 years according to Breeding Bird Survey (BBS) data, and some of the species declining most rapidly were only detected in stands younger than my point count stands $(<6$ years; McDermott chapter 3,4). I suggest that two-age harvesting provides suitable habitat for early-successional breeders in the short-term, and may be used as an alternative to clearcutting for such purposes. However, some species more sensitive to residual tree cover, such as Common Yellowthroats (Geothlypis trichas) and Field Sparrows (Spizella pusilla), may require habitat with more open canopy like clearcuts and old fields (McDermott chapter 3, 4). These two species were detected mainly in clearcuts, but not within $50 \mathrm{~m}$ during point counts. Thus, in extensively forested landscapes, where this type of harvest would have less overall impact on nest success of forestinterior species (Welsh \& Healy 1993; Annand \& Thompson 1997; Duguay et al. 2001; King et al. 2001), stand-scale clearcutting is the best conservation alternative for some early-successional breeders.

\section{Generalist breeders}

Amongst the generalists, some species were more common in younger stands and some in older stands. Of species of conservation interest in the Appalachian Mountains Bird Conservation Region (Partners in Flight, Panjabi et al. 2005), two species were most common in young stands: the Hooded Warbler and Northern Flicker. These species tend to use second growth forest or forest with canopy gaps and open woods. The Canada Warbler was mostly

found in young two-age stands and mature forest; this species appeared to avoid older pole-stage stands, as also found by Lambert and Faccio (2005). Wood Thrush relative abundance was similar in all treatments, and Duguay et al. (2001) found all treatments to be population sources based on nest productivity for this species. Veeries likely used two-age stands more than clearcuts because they were at higher elevations, and young stands because of a denser understory compared to old stands (Moskoff 1995). Overall, generalist species had a positive 
response to both harvest types and used forest in various stages of succession, but some species were notably absent from the older, 19-26 year old, harvests (e.g., Canada Warblers and Hooded Warblers).

In terms of temporal changes, Wood Thrushes, Veeries, Hooded Warblers, and Rosebreasted Grosbeaks declined in all treatments. Hooded Warbler decreases were probably a result of changes in vegetation due to succession; this species decreased more profoundly in harvest treatments. Decreases in relative abundances of the other three species were likely aligned with regional population declines (Table 3). As clearcuts matured, they provided habitat for Northern Flickers, Red-bellied Woodpeckers, and American Redstarts, which were largely absent during 1994-1996.

Brown-headed Cowbirds were three times as common in young two-age stands as the other treatments in 2005-2006. Immediately post-harvest, cowbird abundances may increase in two-age stands (Baker \& Lacki 1997; Weakland 2000). In the Kentucky study, the surrounding landscape was 25\% forested (Baker \& Lacki 1997), explaining the dominance of cowbirds compared to more extensively forested managed areas and providing evidence that two-age harvests in agricultural-dominated landscapes could have negative repercussions for host species. However, increases are short-lived even in fragmented landscapes (M. White, Indiana University of Pennsylvania, personal communication), and this species is still relatively uncommon in our study area which is $80-90 \%$ forested. Nests found by Duguay et al. (2001) had low cowbird parasitism incidence, $6 \%$ of nests, despite higher numbers of cowbirds in two-age stands. Moreover, the Brown-headed Cowbird has exhibited a significant downward trend in the Central Appalachians such that their impact on nest success of breeding birds will lessen in regions where it is already low. Brown-headed Cowbird relative abundance declined significantly in the older stands over the 10 year period, especially the unharvested treatment. Consequently, twoage harvests situated within contiguous forest and far from agricultural areas or other suitable cowbird foraging sites should not pose a threat to the nesting success of forest breeding birds.

Blue Jays, the most abundant avian nest predators detected by point counts, were common in young clearcuts, but relatively rare in two-age stands. Over the 10 year period, Blue Jays increased in two of three treatments, but the sample size was relatively low. Although nest predation impacts more nests than brood parasitism in the study area (Weakland 2000; Duguay et al. 2001), it is not clear how much of an impact Blue Jays have compared to other nest predators. 
However, corvids did not depredate any of 23 depredated Wood Thrush nests monitored with video cameras in the Monongahela National Forest (Williams \& Wood 2002); small mammals and raptors were the primary predators.

\section{Late-successional breeders}

Late-successional breeding species were more flexible in their habitat use compared to their early-successional counterparts; individuals often were observed using residual trees as song perches or for foraging in the young harvested stands. Additionally, some were occasionally observed foraging in the dense understory of the young harvests, but these birds may have been floaters or nesting in the adjacent forest (Chambers et al. 1999; Pagen et al. 2000). The use of young harvests may be related to the importance of the landscape scale in determining habitat suitability. North-central West Virginia contains large areas of contiguous forest $(80-90 \%$ forested in the study area), with fine-scale disturbances embedded within the forested matrix. Many forest-interior species respond less negatively to small amounts of edge compared to extensive edge in highly fragmented landscapes, e.g., forested areas of the agricultural Midwest (Welsh \& Healy 1993; Annand \& Thompson 1997; Yahner 2000; Duguay et al. 2001; King et al. 2001; Weakland \& Wood 2005).

Differences in total relative bird abundance between 2005 and 2006 were primarily influenced by presence of late-successional breeders. Relative abundances in the two-age stands (of both ages) increased greatly in 2006. The increases were not driven by any particular species, but rather, most late-successional species were detected in greater numbers in 2006. Most of these species, as expected, were most common in mature forest, but often were rivaled in numbers in old clearcuts and two-age stands (e.g., Black-throated Blue Warblers, Blackthroated Green Warblers, and Blue-headed Vireos). Thus, despite the overall low bird abundance and diversity in these older harvests, they provided habitat for late-successional breeders, many of which have faced steep population declines in recent years (Sauer et al. 2005).

At an older successional stage (19-26 years post-harvest), both two-age stands and clearcuts may be of conservation importance for the Acadian Flycatcher, Black-and-white Warbler, Blackburnian Warbler, Scarlet Tanager, and Worm-eating Warbler, and perhaps other species of concern in areas outside of the study extent. All of these species were present in the old harvests to some degree. Thus, upon reaching the pole-sawtimber stage, forests provide an 
increase in habitat for some species. Blue-headed Vireo and Scarlet Tanager relative abundances increased in two-age stands and that of the Black-throated Green Warbler in clearcuts as these stands matured. Therefore, old harvests provide habitat for some mature forest species as they approach later seral stages, but abundances in mature forest were still greater than those in 19-26 year old stands.

The Black-and-white Warbler was detected most often in young two-age stands and clearcuts of both age classes. The young treatments had the highest shrub density, an important nesting requirement for this species, and the young two-age stands and old clearcuts had mature trees, essential for the bark-foraging habits of this species. These three treatments also had the highest sapling richness. The unharvested and old two-age stands were higher in elevation and had a more mixed-forest component on average, perhaps explaining why the Black-and-white Warbler was uncommon these stands. Although this forest-interior species is typically associated with mid to late-successional forests (Kricher 1995), other studies have found it to prefer early-successional habitat (Hagan et al. 1997), to be much more abundant in managed vs. reserved landscapes (Thompson et al. 1992; Welsh \& Healy 1993) or to be significantly less abundant in mature forest compared to harvested stands (Annand \& Thompson 1997; Boardman \& Yahner 1999; Costello et al. 2000; King \& DeGraaf 2000; Yahner 2003). The results of this and other studies imply that Black-and-white Warblers may benefit from harvesting, but habitatspecific nest data have not been adequately collected to support this conclusion. Additionally, Black-and-white Warblers were common in harvested treatments in all years of both studies and lower in relative abundance in unharvested stands compared to harvests except in 2005. Interestingly, relative abundance of this species remained stable in all years and all treatments indicating that the Black-and-white Warbler may have a larger niche breadth than previously thought.

Relative abundance of the Cerulean Warbler, a species of concern, declined to 0 in twoage stands and mature forest, although there was a slight increase in the clearcuts. In 2005-2006 this species was detected in four point count stands within $50 \mathrm{~m}$ and one additional stand within $100 \mathrm{~m}$; only two of these five stands were also surveyed in 1994-1996. Cerulean Warblers were detected in seven stands in 1994-1996 (only one of which was not surveyed in 2005-2006). The drops in two-age and unharvested treatments could be accounted for by vegetation changes, perhaps resulting from forest maturation, but this species is uncommon in the study area. 
Relative abundances of some species, e.g., Acadian Flycatcher, Cerulean Warbler, and Eastern Wood-Pewee, declined significantly in unharvested stands suggesting that these declines reflect regional population declines, especially for the latter two species, which declined $\sim 7 \%$ and $4.5 \%$ per year respectively since 1994 according to BBS trends (Sauer et al. 2005; 8\% in my study). Vegetation characteristics in unharvested stands remained relatively stable, except for a decrease in snags, and changes in ground cover, which should not affect these canopydwelling, cup-nesting species. Bird populations in relatively undisturbed mature forest do not necessarily remain stable over time; and declines in unharvested stands for these species could also have been influenced by structural changes in the unharvested stands (e.g., natural succession and tree disease) (Holmes \& Sherry 2001).

\section{Conclusions}

Two-age silviculture is showing promise as a technique that creates habitat for both mature forest and early-successional species. Some regions have increased the use of group or single-tree selection harvests in recent years as clearcutting on public lands has decreased. These harvests, while maintaining much of the mature forest bird community, do not support some species that have been found exclusively in clearcuts (Annand \& Thompson 1997; Robinson \& Robinson 1999; Costello et al. 2000; King et al. 2001). However, my study determined that early-successional species not found in group selection cuts, usually $\leq 1$ ha in size, use two-age harvests as well as clearcuts. For example, Eastern Towhees (Annand \& Thompson 1997; Costello et al. 2000); Blue-winged Warblers (Vermivora pinus) and Brown Thrashers (Toxostoma rufum, Robinson \& Robinson 1999); Indigo Buntings (Costello et al. 2000; King et al. 2000); and Northern Flickers and Song Sparrows (Melospiza melodia, Costello et al. 2000) were absent from group selection harvests but not clearcuts. All of these species were detected, often with high-frequency, in two-age stands in my study (see also McDermott Chapter 3, 4) or others (Baker \& Lacki 1997; Boardman \& Yahner 1999; Duguay et al. 2001). Moreover, several of these species nested in two-age stands in the original study (Nichols 1996; Duguay et al. 2001). Another recent study found that group selection harvests were too small to support some early-successional breeders that nested in young seed-tree stands, which are similar in appearance to low-leave, two-age harvests at that age (10-25 trees/ha; Alterman et al. 2005). 
Some early-successional breeding species are highly specialized in their habitat requirements compared to mature forest species (Askins 1993; King et al. 2001). Mature forest birds, including some typical late-successional breeders, proved to be quite flexible in their habitat requirements in my study system, an extensively forested region of West Virginia. Sixtyseven percent of late-successional species occurred in the young harvests and $76 \%$ in the old harvested stands, often using residual trees. Two-age stands were used as often as clearcuts. Thus, from a population perspective, two-age harvesting is an advantageous choice over clearcutting and selective harvesting in terms of providing habitat for both mature forest and early-successional species, while lowering the intensity of disturbance associated with negative ecological and aesthetic impacts.

Two-age silviculture is of conservation significance because early-successional habitat is provided for species declining at a broader region-wide scale, and in extensively forested landscapes, managed areas are becoming increasingly important for early-successional species (Yahner 2003; Fink et al. 2006). Additionally, two-age harvests of a young age are used by mature forest species, and species richness of late-successional species increases as these stands mature. Over a 10 year period, early-successional species relative abundance dropped greatly in the two-age harvests, but habitat was provided for mature forest species. Accordingly, as vegetative structure changes over time, two-age stands provide habitat for a wide range of species of conservation concern.

I did not collect reproductive data to determine if relative abundance in these stands is indicative of habitat quality (Van Horne 1983; Fink et al. 2006). Future research should focus on long-term reproductive success in two-age stands and in fragmented landscapes vs. large blocks of contiguous forest. Duguay et al. (2001) determined from nest survival data that all treatments (two-age, clearcut, harvest peripheries, and unharvested) were source habitats for Wood Thrushes. Additionally, nest survival did not vary significantly among treatments for $80 \%$ of species with the most nests found. However, avian reproductive data has not been collected in two-age stands situated in highly fragmented landscapes.

The snapshot of harvests at different ages (2005-2006 data) reflected some of the temporal patterns observed in the harvests over time, but not regional population trends, and it is impossible to replicate exact conditions across stands and treatment types. Thus, long-term 
studies in changing landscapes are increasingly important to document spatial and temporal patterns in bird populations.

\section{Literature Cited}

Alterman, L. E., J. C. Bednarz, and R. E. Thill. 2005. Use of group-selection and seed-tree cuts by three early-successional migratory species in Arkansas. Wilson Bulletin 117:353-363.

Annand, E. M. and F. R. Thompson III. 1997. Forest bird response to regeneration practices in Central hardwood forests. Journal of Wildlife Management 61:159-171.

Askins, R. A. 1993. Population trends in grassland, shrubland, and forest birds in eastern North America. Current Ornithology 11:1-34.

Baker, M. D., and M. J. Lacki. 1997. Short-term changes in bird communities in response to silvicultural prescriptions. Forest Ecology and Management 96:27-36.

Boardman, L. A., and R. H. Yahner. 1999. Wildlife communities associated with even-aged Reproduction stands in two state forests of Pennsylvania. Northern Journal of Applied Forestry 16:89-95.

Brawn, J. D., S. K. Robinson, and F. R. Thompson III. 2001. The role of disturbance in the ecology and conservation of birds. Annual Review of Ecology and Systematics 32:251276.

Chambers, C. L., W. C. McComb, and J. C. Tappeiner II. 1999. Breeding bird responses to three silvicultural treatments in the Oregon Coast Range. Ecological Applications 9:171185.

Cody, M. L. 1981. Habitat selection in birds: the roles of vegetation structure, competitors, and productivity. BioScience 31:107-113.

Costello, C. A., M. Yamasaki, P. J. Pekins, W. B. Leak, and C. D. Neefus. 2000. Songbird response to group selection harvests and clearcuts in a New Hampshire northern hardwood forest. Forest Ecology and Management 127:41-54.

DeGraaf, R. M., and M. Yamasaki. 2003. Options for managing early-successional forest and shrubland bird habitats in the northeastern United States. Forest Ecology and Management 185:179-191.

Duguay, J. P., P. B. Wood, and G. W. Miller. 2000. Effects of timber harvests on invertebrates biomass and avian nest success. Wildlife Society Bulletin 28:1123-1131. 
Duguay, J. P., P. B. Wood, and J. V. Nichols. 2001. Songbird abundance and avian nest Survival rates in forests fragmented by different silvicultural treatments. Conservation Biology 15:1405-1415.

Ehrlich, P. R., D. S. Dobkin, and D. Wheye. 1988. The birder's handbook. Simon and Schuster, New York.

Fink, A. D., F. R. Thompson III, and A. A. Tudor. 2006. Songbird use of regenerating forest, glade, and edge habitat types. Journal of Wildlife Management 70:180-188.

Gram, W. K., P. A. Porneluzi, R. L. Clawson, J. Faaborg, and S.C. Richter. 2003. Effects of experimental forest management on density and nesting success of bird species in Missouri Ozark forests. Conservation Biology 17:1324-1337.

Hagan, J. M., P. S. McKinley, A. L. Meehan, and S. L. Grove. 1997. Diversity and abundance of landbirds in a northeastern industrial forest. Journal of Wildlife Management 61:718735.

Holmes, R. T., and T. W. Sherry. 2001. Thirty-year bird population trends in an unfragmented temperate deciduous forest: importance of habitat change. Auk 118:589-609.

Hunter, W. C., D. A. Buehler, R. A. Canterbury, J. L Confer, and P. B. Hamel. 2001. Conservation of disturbance-dependent birds in eastern North America. Wildlife Society Bulletin 29:440-455.

James, F. C., and H. H. Shugart, Jr. 1970. A quantitative method of habitat description. Audubon Field Notes 24:727-736.

Jobes, A. P., E. Nol, and D. R. Voigt. 2004. Effects of selection cutting on bird communities in contiguous eastern hardwood forests. Journal of Wildlife Management 68:51-60.

Keller, J. K., M. E. Richmond, and C. R. Smith. 2003. An explanation of patterns of breeding bird species richness and density following clearcutting in northeastern USA forests. Forest Ecology and Management 174:541-564.

King, D. I., and R. M. DeGraaf. 2000. Bird species diversity and nesting success in mature, clearcut and shelterwood forest in northern New Hampshire, USA. Forest Ecology and Management 129:227-235.

King, D. I., R. M. DeGraaf, and C. R. Griffin. 2001. Productivity of early successional shrubland birds in clearcuts and groupcuts in an Eastern deciduous forest. Journal of Wildlife Management 65:345-350.

Kricher, J. C. 1995. Black-and-white Warbler (Mniotilta varia). In A. Poole and F. Gill, editors. The Birds of North America, No. 158. The Academy of Natural Sciences, Philadelphia, and The American Ornithologists' Union, Washington, D.C. 
Lambert, J. D., and S. D. Faccio. 2005. Canada warbler: population status, habitat use, and stewardship guidelines for northeastern forests. VINS Technical Report 05-4. Vermont Institute of Natural Sciences. Woodstock, VT. 19 pages.

Litvaitis, J. A. 1993. Response of early-successional vertebrates to historical changes in land uses. Conservation Biology 7:866-881.

Maurer, B. A., L. B. McArthur, and R. C. Whitmore. 1981. Effects of logging on guild structure of a forest bird community in West Virginia. American Birds 35:11-13.

Miller, G. W., P. B. Wood, and J. V. Nichols. 1995. Two-age silviculture: an innovative tool for enhancing species diversity and vertical structure in Appalachian hardwoods. Pages 175182 in L.G. Eskew, compiler. Forest health through silviculture. Proceedings of the 1995 national silviculture workshop. General technical report RM-GTR-267. U.S. Forest Service, Rocky Mountain Forest and Range Experiment Station, Fort Collins, Colorado.

Miller, G. W., J. N. Kochenderfer, and D. B. Fekedulegn. 2006. Influence of individual reserve trees on nearby reproduction in two-aged Appalachian hardwood stands. Forest Ecology and Management 224:241-251.

Mitchell, L. J., R. A. Lancia, R. Lea, and S. A. Gauthreaux, Jr. 1991. Effects of clearcutting and natural regeneration on breeding bird communities of a baldcypress-tupelo wetland in South Carolina. Pages 155-161 in J. A. Kusler and S. Daly, editors. Proceedings of the Symposium on Wetlands and River Corridor Management. Association Wetland Management, Bern, New York.

Moskoff, W. 1995. Veery (Catharus fuscescens). In A. Poole and F. Gill, editors. The Birds of North America, No. 142. The Academy of Natural Sciences, Philadelphia, and The American Ornithologists' Union, Washington, D.C.

Nichols, J. V. 1996. Effects of two-age timber management and clearcutting on songbird density and reproductive success. M.S. Thesis. West Virginia University, Morgantown, West Virginia.

Pagen, R. W., F. R. Thompson, III, and D. E. Burhans. 2000. Breeding and post-breeding habitat use by forest migrant songbirds in the Missouri Ozarks. Condor 102:738-747.

Panjabi, A. O., E. H. Dunn, P. J. Blancher, W. C. Hunter, B. Altman, J. Bart, C. J. Beardmore, H. Berlanga, G. S. Butcher, S. K. Davis, D. W. Demarest, R. Dettmers, W. Easton, H. Gomez de Silva Garza, E. E. Iñigo-Elias, D. N. Pashley, C. J. Ralph, T. D. Rich, K. V. Rosenberg, C. M. Rustay, J. M. Ruth, J. S. Wendt, and T. C. Will. 2005. The Partners in Flight handbook on species assessment. Version 2005. Partners in Flight Technical Series No. 3. 
Perkey, A. W., G. W. Miller, and T. M. Schuler. 1999. Regeneration results using two-aged management. Forest Management Update 19:1-9.

Petit, D. R., L. J. Petit, V. A. Saab, and T. E. Martin. 1995. Fixed-radius point counts in forests: factors influencing effectiveness and efficiency. Pages 49-56 in C. J. Ralph, J. R. Sauer, and S. Droege, editors. Monitoring bird populations by point counts. General technical report PSW-GTR-149. U.S. Forest Service, Pacific Southwest Research Station.

Purcell, K. L., S. R. Mori, and M. K. Chase. 2005. Design considerations for examining trends in avian abundance using point counts: examples from oak woodlands. Condor 2:305320.

Ralph, C. J., S. Droege, and J. R. Sauer. 1995. Managing and monitoring birds using point counts: standards and applications. Pages 161-168 in C. J. Ralph, J. R. Sauer, and S. Droege, editors. Monitoring bird populations by point counts. General technical report PSW-GTR-149. U.S. Forest Service, Pacific Southwest Research Station.

Robinson, W. D., and S. K. Robinson. 1999. Effects of selective logging on forest bird populations in a fragmented landscape. Conservation Biology 13:58-66.

SAS Institute. 2003. SAS/STAT users guide. Version 9.1. SAS Institute, Cary, North Carolina.

Sauer, J. R., J. E. Hines, and J. Fallon. 2005. The North American Breeding Bird Survey, Results and Analysis 1966 - 2005. Version 6.2.2006. USGS Patuxent Wildlife Research Center,Laurel, Maryland

Smith, D. M., B. C. Larson, M. J. Kelty, and P. M. S. Ashton. 1997. The practice of silviculture: applied forest ecology. John Wiley \& Sons, New York.

Smith, H. C., N. I. Lamson, and G. W. Miller. 1989. An esthetic alternative to clearcutting? Journal of Forestry 87:14-18.

Sokal, R. R. and F. J. Rohlf. 1995. Biometry, $3^{\text {rd }}$ edition. W. H. Freeman and Company, New York.

Thompson, F. R., W.D. Dijak, T. G. Kulowiec, and D. A. Hamilton. 1992. Breeding bird populations in Missouri Ozark forests with and without clearcutting. Journal of Wildlife Management 56:23-30.

Tittler, R., S. J. Hannon, and M. R. Norton. 2001. Residual tree retention ameliorates short-term effects of clear-cutting on some boreal songbirds. Ecological Applications 11:16561666.

Van Horne, B. 1983. Density as a misleading indicator of habitat quality. Journal of Wildife Management 47:893-901. 
Weakland, C. A. 2000. Songbird response to diameter-limit and two-aged timber harvesting on an industrial forest in central West Virginia. Ph.D. dissertation. West Virginia University, Morgantown, West Virginia.

Weakland, C. A., and P. B. Wood. 2005. Cerulean Warbler (Dendroica cerulea) microhabitat and landscape-level habitat characteristics in southern West Virginia. Auk 122:497-508.

Welsh, C. J., and W. M. Healy. 1993. Effect of even-aged timber management on bird species diversity and composition in northern hardwoods of New Hampshire. Wildlife Society Bulletin 21:143-154.

Whitcomb, R. F., C. S. Robbins, J. F. Lynch, B. L. Klimkiewicz, and D. Bystrak. 1981. Effects of forest fragmentation on avifauna of the eastern deciduous forest. Pages 125-206 in R. L. Burgess, and D. M. Sharpe, editors. Forest island dynamics in man-dominated landscapes. Springer-Verlag, New York.

Wilcove, D. S. 1988. Forest fragmentation as a wildlife management issue in the eastern United States. Pages 146-150 in Healthy forests, healthy world: proceedings of the 1988 Society of American Foresters national convention. Rochester, New York.

Williams, G. E., and P. B. Wood. 2002. Are traditional methods of determining nest predators and nest fates reliable? An experiment with Wood Thrushes (Hylocichla mustelina) using miniature video cameras. Auk 119:1126-1132.

Yahner, R. H. 2000. Long-term effects of even-aged management on bird communities in Pennsylvania. Wildlife Society Bulletin 28:1102-1110.

Yahner, R. H. 2003. Responses of bird communities to early-successional habitat in a managed landscape. Wilson Bulletin 115:292-298.

Zar, J. H. 1999. Biostatistical analysis, $4^{\text {th }}$ edition. Prentice-Hall, New Jersey. 
Table 1. Mean relative bird abundance, species richness, and diversitył(SE) per stand (50-m radius plot) in each of the five treatments during 2005 and 2006 in north-central West Virginia.

\begin{tabular}{|c|c|c|c|c|c|c|c|c|c|c|c|c|}
\hline & Young Clearcut $(6$ & & Young Two-age & & Old Clearcut (6 & & Old Two-age (5 & & Unharvested (6) & & $F(d f=4)$ & $p$ \\
\hline Total bird abundance 2005 & $11.58(1.39)$ & $\mathrm{A}^{b}$ & $8.00(1.26)$ & $\mathrm{BC}$ & $8.33(1.05)$ & $\mathrm{BC}$ & $5.38(0.85)$ & $\mathrm{C}$ & $8.75(0.90)$ & $\mathrm{AB}$ & 3.27 & 0.029 \\
\hline Total bird abundance $2006^{c}$ & $11.50(0.41)$ & A & $12.42(1.11)$ & A & $8.92(0.88)$ & $\mathrm{B}$ & $9.10(1.04)$ & $\mathrm{B}$ & $8.83(0.78)$ & $\mathrm{B}$ & 3.80 & 0.016 \\
\hline Species richness & $11.67(0.83)$ & A & $11.25(1.24)$ & A & $8.17(0.78)$ & $\mathrm{B}$ & $8.11(1.23)$ & B & $11.25(0.60)$ & A & 3.38 & 0.024 \\
\hline Shannon diversity & $2.34(0.07)$ & $\mathrm{A}$ & $2.26(0.14)$ & $\mathrm{AB}$ & $1.98(0.09)$ & $\mathrm{BC}$ & $1.87(0.19)$ & $\mathrm{C}$ & $2.30(0.06)$ & A & 3.65 & 0.018 \\
\hline \multicolumn{13}{|l|}{ Guild abundance } \\
\hline early-successional & $4.0(0.35)$ & A & $3.17(0.47)$ & B & $0.67(0.28)$ & $\mathrm{C}$ & $0.50(0.17)$ & $\mathrm{C}$ & $0.38(0.11)$ & $\mathrm{C}$ & 29.46 & $<0.001$ \\
\hline generalist & $6.08(0.75)$ & & $5.04(0.42)$ & & $4.67(0.59)$ & & $3.94(0.54)$ & & $3.96(0.32)$ & & 1.89 & 0.144 \\
\hline late-successional 2005 & $1.42(0.33)$ & $\mathrm{B}$ & $1.42(0.45)$ & $\mathrm{B}$ & $3.33(0.49)$ & A & $1.63(0.99)$ & B & $4.42(0.55)$ & A & 6.62 & 0.001 \\
\hline late-successional 2006 & $1.50(0.26)$ & $\mathrm{B}$ & $2.58(0.45)$ & $\mathrm{AB}$ & $3.17(0.71)$ & $\mathrm{AB}$ & $4.10(0.97)$ & A & $4.33(0.91)$ & A & 2.78 & 0.050 \\
\hline \multicolumn{13}{|l|}{ Early-succesional species } \\
\hline American Goldfinch & $0.13(0.09)$ & $\mathrm{AB}$ & $0.13(0.07)$ & $\mathrm{AB}$ & 0 & $\mathrm{~B}$ & $0.28(0.15)$ & A & 0 & $\mathrm{~B}$ & 2.95 & 0.040 \\
\hline Chestnut-sided Warbler & $1.42(0.23)$ & $\mathrm{A}$ & $1.13(0.19)$ & A & $0.04(0.04)$ & B & $0.11(0.11)$ & B & $0.04(0.04)$ & B & 18.29 & $<0.001$ \\
\hline Common Yellowthroat & 0 & & $0.08(0.08)$ & & 0 & & 0 & & 0 & & . & d \\
\hline Eastern Towhee & $1.00(0.16)$ & A & $0.46(0.13)$ & B & $0.25(0.13)$ & $\mathrm{BC}$ & $0.06(0.06)$ & $\mathrm{C}$ & $0.08(0.06)$ & $\mathrm{C}$ & 16.21 & $<0.001$ \\
\hline Golden-winged Warbler & $0.21(0.10)$ & & $0.13(0.09)$ & & 0 & & 0 & & 0 & & 2.02 & 0.123 \\
\hline Gray Catbird & $0.38(0.14)$ & & $0.46(0.13)$ & & $0.08(0.08)$ & & $0.06(0.06)$ & & $0.21(0.10)$ & & 1.77 & 0.167 \\
\hline Indigo Bunting & $0.58(0.16)$ & A & $0.33(0.11)$ & $\mathrm{AB}$ & $0.17(0.11)$ & $\mathrm{BC}$ & 0 & $\mathrm{C}$ & 0 & $\mathrm{C}$ & 5.14 & 0.004 \\
\hline Mourning Dove & $0.13(0.09)$ & & $0.13(0.09)$ & & $0.04(0.04)$ & & 0 & & 0 & & . & $d$ \\
\hline Mourning Warbler & $0.08(0.08)$ & & $0.13(0.09)$ & & 0 & & 0 & & $0.04(0.04)$ & & . & $d$ \\
\hline Northern Cardinal & 0 & & $0.21(0.17)$ & & $0.08(0.08)$ & & 0 & & 0 & & . & $d$ \\
\hline White-eyed Vireo & $0.08(0.06)$ & & 0 & & 0 & & 0 & & 0 & & . & $d$ \\
\hline \multicolumn{13}{|l|}{ Generalist species } \\
\hline American Redstart & $0.38(0.19)$ & $\mathrm{B}$ & $0.29(0.13)$ & B & $1.17(0.26)$ & A & $0.28(0.12)$ & B & $0.54(0.19)$ & $\mathrm{AB}$ & 2.60 & 0.061 \\
\hline American Robin & $0.13(0.09)$ & B & 0 & B & $0.17(0.11)$ & $\mathrm{AB}$ & 0 & B & $0.42(0.14)$ & $\mathrm{A}$ & 2.36 & 0.081 \\
\hline Baltimore Oriole & $0.04(0.04)$ & & 0 & & 0 & & 0 & & $0.04(0.04)$ & & . & d \\
\hline Black-capped Chickadee & $0.17(0.09)$ & & $0.17(0.11)$ & & $0.13(0.09)$ & & $0.11(0.11)$ & & $0.17(0.09)$ & & 0.14 & 0.966 \\
\hline Blue-gray Gnatcatcher & 0 & & 0 & & $0.17(0.11)$ & & 0 & & $0.08(0.06)$ & & . & $d$ \\
\hline Blue Jay & $0.75(0.49)$ & & $0.04(0.04)$ & & 0 & & $0.22(0.17)$ & & 0 & & . & $d$ \\
\hline Brown-headed Cowbird & $0.08(0.08)$ & & $0.25(0.13)$ & & $0.08(0.08)$ & & $0.06(0.06)$ & & $0.08(0.06)$ & & 0.62 & 0.649 \\
\hline Canada Warbler & $0.08(0.06)$ & $\mathrm{B}$ & $0.38(0.13)$ & A & 0 & $\mathrm{~B}$ & 0 & B & $0.13(0.09)$ & $\mathrm{AB}$ & 2.67 & 0.056 \\
\hline Cedar Waxwing & $0.42(0.18)$ & & $0.25(0.17)$ & & $0.17(0.17)$ & & $0.28(0.15)$ & & $0.17(0.11)$ & & 0.37 & 0.828 \\
\hline Dark-eyed Junco & 0 & & $0.25(0.12)$ & & $0.33(0.19)$ & & $0.22(0.15)$ & & $0.46(0.14)$ & & 0.92 & 0.467 \\
\hline Downy Woodpecker & 0 & & 0 & & $0.21(0.11)$ & & 0 & & $0.04(0.04)$ & & . & $d$ \\
\hline Hooded Warbler & $0.83(0.09)$ & A & $1.04(0.16)$ & A & $0.04(0.04)$ & B & 0 & B & $0.13(0.09)$ & B & 21.17 & $<0.001$ \\
\hline Northern Flicker & $0.33(0.13)$ & A & $0.21(0.1)$ & $\mathrm{AB}$ & $0.04(0.04)$ & $\mathrm{BC}$ & 0 & $\mathrm{C}$ & 0 & $\mathrm{C}$ & 4.46 & 0.007 \\
\hline
\end{tabular}




\begin{tabular}{|c|c|c|c|c|c|c|c|c|c|c|c|c|}
\hline & Young Clearcut & & Young Two-age & & Old Clearcut & & Old Two-age & & Unharvested & & $F(d f=4)$ & $p$ \\
\hline \multicolumn{13}{|l|}{ Generalist species (continued) } \\
\hline Northern Parula & 0 & & 0 & & $0.04(0.04)$ & & 0 & & $0.04(0.04)$ & & . & $d$ \\
\hline Red-eyed Vireo & $1.17(0.11)$ & $\mathrm{ABC}$ & $0.83(0.18)$ & $\mathrm{C}$ & $1.67(0.18)$ & A & $1.56(0.33)$ & $\mathrm{AB}$ & $1.04(0.13)$ & $\mathrm{BC}$ & 3.07 & 0.035 \\
\hline Rose-breasted Grosbeak 2005 & $1.25(0.25)$ & A & $0.25(0.25)$ & $\mathrm{B}$ & $0.17(0.17)$ & $\mathrm{B}$ & $0.63(0.47)$ & $\mathrm{AB}$ & $0.08(0.08)$ & $\mathrm{B}$ & 4.22 & 0.011 \\
\hline Rose-breasted Grosbeak 2006 & $0.83(0.28)$ & & $0.58(0.24)$ & & $0.33(0.21)$ & & 0 & & $0.42(0.15)$ & & 1.92 & 0.179 \\
\hline Ruby-throated Hummingbird & 0 & & $0.04(0.04)$ & & 0 & & $0.06(0.06)$ & & $0.08(0.06)$ & & . & $d$ \\
\hline Tufted Titmouse & 0 & & $0.08(0.08)$ & & 0 & & $0.06(0.06)$ & & 0 & & . & $d$ \\
\hline Veery & $0.38(0.15)$ & $\mathrm{AB}$ & $0.63(0.18)$ & $\mathrm{A}$ & 0 & $\mathrm{~B}$ & $0.28(0.15)$ & $\mathrm{AB}$ & $0.21(0.1)$ & $\mathrm{B}$ & 2.58 & 0.062 \\
\hline Wood Thrush & $0.21(0.10)$ & & $0.17(0.17)$ & & $0.21(0.11)$ & & $0.50(0.29)$ & & $0.08(0.06)$ & & 0.40 & 0.804 \\
\hline Yellow-billed Cuckoo & $0.08(0.08)$ & & 0 & & 0 & & $0.06(0.06)$ & & 0 & & . & d \\
\hline \multicolumn{13}{|l|}{ Late-successional species } \\
\hline Acadian Flycatcher & 0 & & 0 & & $0.13(0.09)$ & & $0.11(0.07)$ & & $0.21(0.1)$ & & 1.22 & 0.327 \\
\hline Black-and-white Warbler & $0.42(0.12)$ & $\mathrm{AB}$ & $0.71(0.13)$ & $\mathrm{A}$ & $0.63(0.14)$ & A & $0.22(0.15)$ & $\mathrm{BC}$ & $0.04(0.04)$ & $\mathrm{C}$ & 4.84 & 0.005 \\
\hline Blackburnian Warbler & $0.08(0.08)$ & & $0.04(0.04)$ & & $0.21(0.11)$ & & $0.11(0.11)$ & & $0.33(0.15)$ & & 0.82 & 0.524 \\
\hline Black-throated Blue Warbler & $0.08(0.06)$ & $\mathrm{B}$ & $0.04(0.04)$ & $\mathrm{B}$ & $0.04(0.04)$ & $\mathrm{B}$ & $0.5(0.19)$ & A & $0.63(0.11)$ & A & 5.05 & 0.004 \\
\hline Black-throated Green Warbler & $0.04(0.04)$ & $\mathrm{B}$ & $0.17(0.11)$ & $\mathrm{B}$ & $0.54(0.14)$ & $\mathrm{A}$ & $0.11(0.07)$ & $\mathrm{B}$ & $0.79(0.11)$ & A & 7.91 & $<0.001$ \\
\hline Blue-headed Vireo & $0.04(0.04)$ & $\mathrm{C}$ & $0.08(0.08)$ & $\mathrm{C}$ & $0.21(0.11)$ & $\mathrm{BC}$ & $0.44(0.15)$ & $\mathrm{AB}$ & $0.67(0.2)$ & A & 4.92 & 0.005 \\
\hline Brown Creeper & 0 & & 0 & & 0 & & 0 & & $0.08(0.06)$ & & . & $d$ \\
\hline Cerulean Warbler & $0.04(0.04)$ & & $0.17(0.11)$ & & $0.08(0.08)$ & & 0 & & 0 & & . & $d$ \\
\hline Eastern Wood-Pewee & 0 & & $0.08(0.08)$ & & 0 & & 0 & & $0.04(0.04)$ & & . & $d$ \\
\hline Golden-crowned Kinglet & 0 & & 0 & & 0 & & $0.17(0.12)$ & & 0 & & . & $d$ \\
\hline Hairy Woodpecker & $0.04(0.04)$ & $\mathrm{B}$ & $0.04(0.04)$ & $\mathrm{B}$ & 0 & $\mathrm{~B}$ & 0 & $\mathrm{~B}$ & $0.21(0.11)$ & A & 2.89 & 0.043 \\
\hline Hermit Thrush & 0 & & 0 & & $0.04(0.04)$ & & $0.22(0.17)$ & & $0.04(0.04)$ & & . & $d$ \\
\hline Least Flycatcher & $0.08(0.08)$ & & 0 & & 0 & & 0 & & $0.08(0.08)$ & & . & $d$ \\
\hline Magnolia Warbler & $0.33(0.13)$ & & $0.46(0.13)$ & & $0.25(0.1)$ & & $0.28(0.15)$ & & $0.17(0.13)$ & & 0.71 & 0.595 \\
\hline Ovenbird & 0 & & 0 & & $0.54(0.14)$ & & $0.17(0.12)$ & & $0.29(0.25)$ & & 1.92 & 0.138 \\
\hline Pileated Woodpecker & 0 & & $0.08(0.08)$ & & $0.08(0.08)$ & & $0.06(0.06)$ & & $0.04(0.04)$ & & . & $d$ \\
\hline Red-breasted Nuthatch & 0 & & 0 & & 0 & & 0 & & $0.04(0.04)$ & & . & $d$ \\
\hline Scarlet Tanager & $0.21(0.11)$ & & $0.08(0.06)$ & & $0.42(0.17)$ & & $0.44(0.18)$ & & $0.33(0.09)$ & & 0.88 & 0.490 \\
\hline White-breasted Nuthatch & $0.04(0.04)$ & & $0.04(0.04)$ & & 0 & & $0.06(0.06)$ & & $0.04(0.04)$ & & . & a \\
\hline Winter Wren & 0 & $\mathrm{~B}$ & 0 & $\mathrm{~B}$ & 0 & $\mathrm{~B}$ & $0.11(0.07)$ & $\mathrm{B}$ & $0.33(0.09)$ & A & 5.26 & 0.003 \\
\hline Worm-eating Warbler & $0.04(0.04)$ & & 0 & & $0.08(0.08)$ & & 0 & & 0 & & . & $d$ \\
\hline
\end{tabular}

${ }^{a}$ Number of stands sampled.

${ }^{b}$ For a given species or guild means with a different letter differ significantly; Waller-Duncan k-ratio t-tests, $p<0.10$.

${ }^{c}$ Years are presented separately when there was a significant treatment by year interaction effect.

${ }^{d}$ Species too rare for statistical test. 
Table 2. Mean per stand ( \pm SE) for habitat variables (prior to transformation) measured during 2005 and 2006 in 0.04 ha plots around point count stations in five treatments in North-central West Virginia.

\begin{tabular}{|c|c|c|c|c|c|c|c|c|c|c|c|c|}
\hline & Young Clearcut (6) & & Young Two-age (6) & & Old Clearcut (6) & & Old Two-age (5) & & Unharvested (6) & & $\mathrm{F}(\mathrm{df}=4)$ & $p$ \\
\hline Elevation (m) & $791.4(15.0)$ & & $829.3(21.6)$ & & $701.2(14.8)$ & & $895.0(8.1)$ & & $812.0(45.0)$ & & 0.92 & $0.466^{b}$ \\
\hline Slope (\%) & $32.7(3.6)$ & & $33.0(3.6)$ & & $30.6(5.5)$ & & $19.7(6.2)$ & & $27.2(4.2)$ & & 1.45 & 0.248 \\
\hline \multicolumn{13}{|l|}{ Ground cover $(\%)$} \\
\hline herbaceous & $21.6(2.5)$ & & $19.2(4.2)$ & & $14.7(6.8)$ & & $8.3(2.9)$ & & $21.5(4.7)$ & & 1.68 & 0.186 \\
\hline leaf litter & $57.8(4.3)$ & & $63.0(3.6)$ & & $69.4(7.6)$ & & $77.3(4.5)$ & & $61.5(5.0)$ & & 1.81 & 0.158 \\
\hline woody debris & $12.9(2.4)$ & & $11.6(1.3)$ & & $5.6(1.3)$ & & $7.8(2.8)$ & & $7.2(1.0)$ & & 1.14 & 0.359 \\
\hline rock & $5.7(1.8)$ & & $5.1(1.3)$ & & $6.7(2.7)$ & & $2.9(1.3)$ & & $6.7(1.7)$ & & 0.35 & 0.839 \\
\hline \multicolumn{13}{|l|}{ Canopy cover $(\%)$} \\
\hline shrub $0-3 \mathrm{~m}$ & $75.5(3.2)$ & $\mathrm{A}^{c}$ & $74.4(4.7)$ & A & $31.9(6.8)$ & $\mathrm{B}$ & $36.2(10.4)$ & $\mathrm{B}$ & $24.4(4.3)$ & $\mathrm{B}$ & 9.87 & $<0.001$ \\
\hline canopy $>3-6 \mathrm{~m}$ & $76.4(4.9)$ & A & $78.3(3.3)$ & $\mathrm{A}$ & $47.7(6.1)$ & $\mathrm{B}$ & $53.0(8.9)$ & $\mathrm{B}$ & $31.5(3.6)$ & $\mathrm{C}$ & 8.01 & $<0.001$ \\
\hline canopy $>6-12 \mathrm{~m}$ & $39.1(7.2)$ & $\mathrm{B}$ & $47.9(6.0)$ & $\mathrm{B}$ & $69.4(7.4)$ & A & $72.6(3.4)$ & A & $43.2(3.1)$ & $\mathrm{B}$ & 2.53 & 0.066 \\
\hline canopy $>12-18 \mathrm{~m}$ & $5.1(2.8)$ & $\mathrm{C}$ & $21.5(5.9)$ & $\mathrm{B}$ & $65.9(4.9)$ & A & $62.3(8.3)$ & A & $66.2(1.6)$ & $\mathrm{A}$ & 17.33 & $<0.001$ \\
\hline canopy $>18-24 \mathrm{~m}$ & $1.6(1.4)$ & $\mathrm{D}$ & $15.1(3.8)$ & $\mathrm{C}$ & $22.6(9.3)$ & $\mathrm{BC}$ & $34.2(9.1)$ & $\mathrm{B}$ & $78.8(2.6)$ & $\mathrm{A}$ & 18.57 & $<0.001$ \\
\hline canopy $>24 \mathrm{~m}$ & 0 & $\mathrm{C}$ & $2.5(0.7)$ & $\mathrm{C}$ & $1.5(1.3)$ & $\mathrm{C}$ & $8.8(3.0)$ & $\mathrm{B}$ & $37.2(6.1)$ & $\mathrm{A}$ & 21.57 & $<0.001$ \\
\hline Vertical complexity index & $7.9(0.3)$ & $\mathrm{D}$ & $10.5(0.4)$ & $\mathrm{BC}$ & $9.4(0.5)$ & $\mathrm{C}$ & $10.7(7.5)$ & $\mathrm{B}$ & $12.0(0.5)$ & $\mathrm{A}$ & 12.42 & $<0.001$ \\
\hline Basal area $\left(\mathrm{m}^{2} / \mathrm{ha}\right)$ & $3.6(0.8)$ & $\mathrm{E}$ & $8.5(1.8)$ & $\mathrm{D}$ & $16.9(1.0)$ & $\mathrm{C}$ & $20.6(1.7)$ & B & $33.6(1.7)$ & A & 50.38 & $<0.001$ \\
\hline \multicolumn{13}{|l|}{ Number of stems (dbh class) } \\
\hline seedlings and other stems $0-2.5 \mathrm{~cm}$ & $154.1(32.5)$ & $\mathrm{A}$ & $151.5(30.5)$ & $\mathrm{A}$ & $33.9(9.7)$ & $\mathrm{B}$ & $27.0(9.5)$ & $\mathrm{B}$ & $14.7(6.2)$ & $\mathrm{B}$ & 4.09 & 0.011 \\
\hline saplings $2.6-7.6 \mathrm{~cm}$ & $25.1(3.8)$ & A & $20.5(4.0)$ & A & $9.4(1.2)$ & $\mathrm{B}$ & $9.3(1.1)$ & $\mathrm{B}$ & $3.1(0.7)$ & $\mathrm{C}$ & 13.57 & $<0.001$ \\
\hline poles $7.7-15.2 \mathrm{~cm}$ & $5.2(1.2)$ & $\mathrm{B}$ & $3.6(0.8)$ & $\mathrm{B}$ & $21.5(1.6)$ & $\mathrm{A}$ & $18.6(3.4)$ & A & $4.0(0.6)$ & $\mathrm{B}$ & 12.72 & $<0.001$ \\
\hline sum all stems $<15.3 \mathrm{~cm}$ & $184.4(33.0)$ & A & $175.6(29.2)$ & A & $64.7(12.2)$ & $\mathrm{B}$ & $54.9(9.4)$ & $\mathrm{B}$ & $21.7(6.6)$ & $\mathrm{B}$ & 5.11 & 0.004 \\
\hline species richness of stems $<15.3 \mathrm{~cm}$ & $9.8(0.5)$ & A & $9.4(0.8)$ & $\mathrm{A}$ & $10.2(1.1)$ & A & $6.4(0.7)$ & $\mathrm{B}$ & $3.8(0.4)$ & $\mathrm{C}$ & 10.70 & $<0.001$ \\
\hline trees $15.3-22.9 \mathrm{~cm}$ & $0.6(0.2)$ & $\mathrm{C}$ & $1.1(0.4)$ & $\mathrm{BC}$ & $5.1(1.0)$ & $\mathrm{A}$ & $4.3(1.3)$ & A & $2.5(0.5)$ & $\mathrm{B}$ & 7.99 & $<0.001$ \\
\hline trees $23-30.5 \mathrm{~cm}$ & $0.04(0.03)$ & $\mathrm{C}$ & $1.2(0.4)$ & $\mathrm{BC}$ & $2.2(0.5)$ & $\mathrm{AB}$ & $1.8(0.4)$ & $\mathrm{AB}$ & $2.4(0.4)$ & $\mathrm{A}$ & 5.10 & 0.004 \\
\hline trees $30.6-38.1 \mathrm{~cm}$ & 0 & $\mathrm{C}$ & $1.0(0.3)$ & $\mathrm{B}$ & $0.2(0.1)$ & $\mathrm{C}$ & $0.6(0.3)$ & $\mathrm{BC}$ & $1.8(0.2)$ & A & 5.78 & 0.002 \\
\hline trees $>38.1 \mathrm{~cm}$ & $0.2(0.1)$ & $\mathrm{C}$ & $0.9(0.2)$ & $\mathrm{C}$ & $0.3(0.1)$ & $\mathrm{C}$ & $1.7(0.4)$ & $\mathrm{B}$ & $4.5(0.4)$ & A & 27.18 & $<0.001$ \\
\hline sum of all trees $>15.3 \mathrm{~cm}$ & $0.8(0.2)$ & $\mathrm{D}$ & $4.1(1.1)$ & $\mathrm{C}$ & $7.7(1.1)$ & $\mathrm{B}$ & $8.4(1.4)$ & $\mathrm{B}$ & $11.1(1.0)$ & A & 13.52 & $<0.001$ \\
\hline tree species richness & $0.6(0.2)$ & $\mathrm{D}$ & $2.0(0.5)$ & $\mathrm{C}$ & $2.9(0.2)$ & $\mathrm{BC}$ & $2.9(0.4)$ & $\mathrm{B}$ & $4.8(0.3)$ & $\mathrm{A}$ & 17.86 & $<0.001$ \\
\hline \multicolumn{13}{|l|}{ Number of snags (dbh class) } \\
\hline snags $7.7-15.2 \mathrm{~cm}$ & $0.02(0.02)$ & $\mathrm{B}$ & $0.05(0.03)$ & $\mathrm{B}$ & $1.1(0.4)$ & A & $0.8(0.5)$ & A & $0.3(0.1)$ & $\mathrm{B}$ & 4.07 & 0.011 \\
\hline snags $>15.3 \mathrm{~cm}$ & $0.03(0.03)$ & $\mathrm{B}$ & $0.15(0.06)$ & $\mathrm{B}$ & $0.10(0.05)$ & $\mathrm{B}$ & $0.3(0.1)$ & $\mathrm{B}$ & $0.8(0.2)$ & $\mathrm{A}$ & 9.51 & $<0.001$ \\
\hline
\end{tabular}

${ }^{a}$ Number of stands sampled.

${ }^{b}$ After experiment-wide Bonferroni corrections, tests are significant at the 0.004 alpha level.

${ }^{c}$ For a given metric means with a different letter differ significantly; Waller-Duncan k-ratio t-tests. 
Table 3. Mean relative bird abundance, species richness, and diversity ( $\pm \mathrm{SE})$ per stand (100-m radius plots) in 3 treatments during 1994-1996 and 2005-2006 on the Monongahela National Forest, West Virginia.

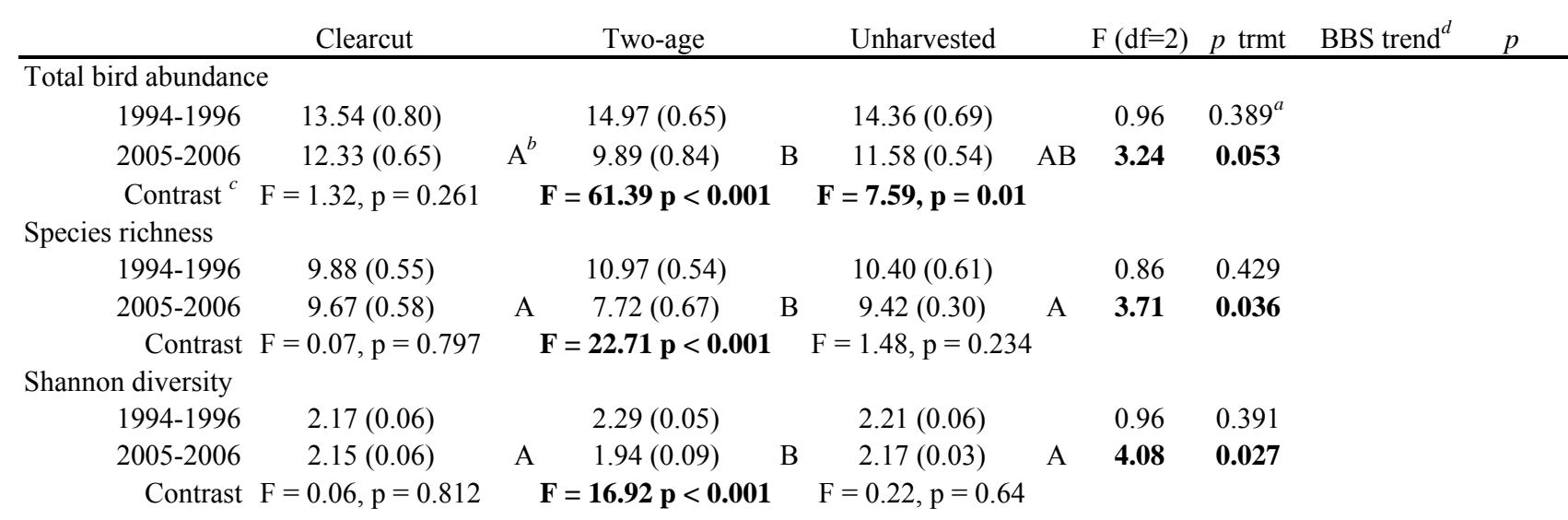

Guild abundance

early-successional

$\begin{array}{rlllllllc}1994-1996 & 1.64(0.29) & \text { B } & 3.08(0.56) & \text { A } & 0.71(0.18) & \text { C } & \mathbf{1 0 . 8 8} & <\mathbf{0 . 0 0 1} \\ 2005-2006 & 0.79(0.21) & \text { A } & 0.22(0.12) & \text { B } & 0.38(0.13) & \text { AB } & \mathbf{3 . 2 1} & \mathbf{0 . 0 5 4} \\ \text { Contrast } & \mathbf{F}=\mathbf{4 . 3 4}, \mathbf{p}=\mathbf{0 . 0 4 8} & \mathbf{F}=\mathbf{1 3 . 3 6} \mathbf{p}=\mathbf{0 . 0 0 1} & \mathrm{F}=1.71, \mathbf{p}=0.202 & & \end{array}$
generalist

Contrast $\mathbf{F}=\mathbf{4 . 3 4}, \mathbf{p}=\mathbf{0 . 0 4 8} \quad \mathbf{F}=\mathbf{1 3 . 3 6} \mathbf{p}=\mathbf{0 . 0 0 1} \quad \mathrm{F}=1.71, \mathrm{p}=0.202$

$\begin{array}{rl}1994-1996 & 7.56(0.61) \\ 2005-2006 & 6.96(0.57) \\ \text { Contrast } & \mathrm{F}=0.45, \mathrm{p}=0.50\end{array}$

late-successional

1994-1996

2005-2006

Contrast $\mathrm{F}=0.1, \mathrm{p}=0.754$

$$
\begin{aligned}
& 8.67(0.54) \quad 7.02(0.49) \\
& 5.61(0.65) \quad 5.17(0.34) \\
& F=13.06 p=0.002 \quad F=6.56, p=0.016 \\
& \begin{array}{llll}
\text { B } & \text { B } & \\
& 3.19(0.33) & & 6.50(0.44)
\end{array} \\
& 4.06(0.73) \quad 5.96(0.62) \\
& \mathrm{F}=1.26 \mathrm{p}=0.273 \quad \mathrm{~F}=0.51, \mathrm{p}=0.483
\end{aligned}
$$

Neotropical migrants

$$
\begin{array}{rccc}
1994-1996 & 10.94(0.62) & 11.64(0.50) & 12.10(0.51) \\
2005-2006 & 9.50(0.67) & 7.11(0.85) & 8.33(0.69) \\
\text { Contrast } & F=2.55, \mathbf{p}=0.123 & \mathbf{F}=\mathbf{3 2 . 5 8} \mathbf{p}<\mathbf{0 . 0 0 1} & \mathbf{F}=\mathbf{1 8 . 7 5}, \mathbf{p}<\mathbf{0 . 0 0 1}
\end{array}
$$

Early-successional species

Chestnut-sided Warbler

$$
\begin{array}{rc}
1994-1996 & 0 \\
2005-2006 & 0.04(0.04) \\
\text { Contrast } & F=1.50, p=0.232
\end{array}
$$

$$
\text { B }
$$

$$
1.11(0.28)
$$$$
0
$$$$
F=6.90 p=0.015
$$

$$
\text { A }
$$

$$
0.02(0.02)
$$$$
0.04(0.04)
$$

B

16

$16.04<0.001$

$0.37 \quad 0.693$

Eastern Towhee

$$
\begin{array}{rc}
1994-1996 & 0.50(0.14) \\
2005-2006 & 0.13(0.09) \\
\text { Contrast } \mathbf{F}=\mathbf{3 . 7 7}, \mathbf{p}=\mathbf{0 . 0 6 3}
\end{array}
$$

Gray Catbird

$$
\begin{array}{rl}
1994-1996 & 0.03(0.03) \\
2005-2006 & 0.08(0.08) \\
\text { Contrast } & F=0.53, p=0.472
\end{array}
$$

Indigo Bunting

$$
\begin{array}{ll}
1994-1996 & 0.81(0.18) \\
2005-2006 & 0.33(0.14)
\end{array}
$$$$
\text { Contrast } \mathbf{F}=\mathbf{3 . 4 8 ,} \mathbf{p}=\mathbf{0 . 0 7 4}
$$

Northern Cardinal

1994-1996

2005-2006

$$
0.25(0.08)
$$$$
0.08(0.08)
$$

Contrast $F=1.74, p=0.199$

$$
\begin{aligned}
& 0.42(0.14) \\
& 0.06(0.06) \\
\mathbf{F =} & \mathbf{3 . 7 1} \mathbf{p}=\mathbf{0 . 0 6 7} \\
& 0.22(0.09) \\
& 0.06(0.06) \\
\mathrm{F}= & 1.42 \mathrm{p}=0.246
\end{aligned}
$$$$
\mathrm{F}=0.16, \mathrm{p}=0.691
$$$$
0.89 \quad 0.429
$$

$-1.46$

$0.21(0.08)$

$0.13(0.07)$$$
0
$$$$
0.13(0.09)
$$$$
F=3.82, p=0.061
$$

$2.22 \quad 0.141$

$-0.19 \quad 0.727$

$-0.44 \quad 0.472$

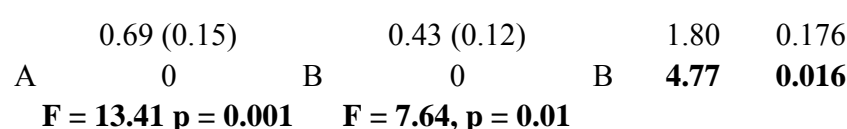

$2.04 \quad 0.163$

$-0.06$

0.911 
Table 3 continued

Clearcut

Two-age

Unharvested

$\mathrm{F}(\mathrm{df}=2) \quad p$ trmt $\quad$ BBS trend $\quad p$

Generalist species

American Redstart

1994-1996

2005-2006

$0.53(0.23)$

$1.25(0.27)$

$0.39(0.13)$

$0.50(0.12)$

0.19

0.828

Contrast $F=4.03, p=0.056$

$\mathrm{F}=0.18 \mathrm{p}=0.677 \quad \mathrm{~F}=0.70, \mathrm{p}=0.411$

American Robin

1994-1996

$0.03(0.03)$

$0.25(0.18)$

$0.17(0.07)$

$2.25 \quad 0.137$

2005-2006

$$
\begin{array}{cc}
0 & 0.67(0.19) \\
\mathrm{F}=2.91, \mathrm{p}=0.102 & \mathbf{F}=\mathbf{9 . 9 4}, \mathbf{p}=\mathbf{0 . 0 0 4}
\end{array}
$$

Contrast $\mathrm{F}=2.03, \mathrm{p}=0.167$

Black-capped Chickadee

$\begin{array}{rl}1994-1996 & 0.44(0.13) \\ 2005-2006 & 0.33(0.13) \\ \text { Contrast } & F=0.32, p=0.578\end{array}$

$$
\begin{array}{cc}
0.31(0.10) & 0.10(0.04) \\
0.22(0.17) & 0.25(0.14) \\
\mathrm{F}=0.37 \mathrm{p}=0.548 & \mathrm{~F}=1.55, \mathrm{p}=0.224
\end{array}
$$

Blue-gray Gnatcatcher

$$
\begin{array}{rlcc}
1994-1996 & 0.19(0.10) & 0.14(0.09) & 0.17(0.08) \\
2005-2006 & 0.17(0.11) & 0 & 0.04(0.04) \\
\text { Contrast } & F=0.01, \mathrm{p}=0.905 & \mathrm{~F}=1.48 \mathrm{p}=0.237 & \mathrm{~F}=1.17, \mathrm{p}=0.288
\end{array}
$$

Blue Jay

$$
\begin{array}{rl}
1994-1996 & 0.27(0.11) \\
2005-2006 & 0.17(0.11) \\
\text { Contrast } & F=0.42, p=0.524
\end{array}
$$

$$
\begin{array}{ccccc}
\text { A } & 0.03(0.03) & \text { B } & 0.02(0.02) & \text { B } \\
\text { B } & \begin{array}{c}
0.67(0.22) \\
\text { F }=\mathbf{1 6 . 7 8} \mathbf{p}=\mathbf{0 . 0 0 1}
\end{array} & \text { A } & 0.17(0.09) & \text { B }=\mathbf{3 . 1 6}, \mathbf{p}=\mathbf{0 . 0 8 6}
\end{array}
$$

4.86

0.012

Brown-headed Cowbird

$\begin{array}{rc}1994-1996 & 0.27(0.08) \\ 2005-2006 & 0.08(0.08) \\ \text { Contrast } & F=2.25, p=0.146\end{array}$

$0.21 \quad 0.811$

$-1.47 \quad 0.299$

1994-1996

$$
0
$$

2005-2006$$
0
$$

Contrast

Cedar Waxwing

$$
\begin{array}{rc}
1994-1996 & 0.08(0.06) \\
2005-2006 & 0 \\
\text { Contrast } & F=1.20, p=0.284
\end{array}
$$

Dark-eyed Junco

$$
\begin{array}{cc}
1994-1996 & 0 \\
2005-2006 & 0.33(0.19)
\end{array}
$$

Contrast $\mathbf{F}=\mathbf{4 . 6 2}, \mathbf{p}=\mathbf{0 . 0 4 2}$

Downy Woodpecker

$\begin{array}{ll}1994-1996 & 0.03(0.03) \\ 2005-2006 & 0.08(0.08)\end{array}$

Contrast $F=0.53, p=0.472$

Great Crested Flycatcher

$$
\text { 1994-1996 } 0.11(0.06)
$$

2005-2006 $0.08(0.08)$

$$
\text { Contrast } F=0.07, p=0.79
$$

Hooded Warbler

$$
\begin{array}{ll}
1994-1996 & 0.76(0.15) \\
2005-2006 & 0.13(0.09)
\end{array}
$$

Contrast $\mathbf{F}=\mathbf{1 8 . 0 0}, \mathbf{p}<\mathbf{0 . 0 0 1}$

Northern Flicker

1994-1996

2005-2006

0

$0.25(0.12)$

Contrast $\mathrm{F}=\mathbf{6 . 4 3}, \mathrm{p}=\mathbf{0 . 0 1 8}$

Northern Parula

$\begin{array}{rc}1994-1996 & 0.14(0.07) \\ 2005-2006 & 0.08(0.06) \\ \text { Contrast } & F=0.33, p=0.574\end{array}$

A

B

0

0

$0.02(0.02)$

$$
0.08(0.05)
$$

$$
\mathrm{F}=1.68 \mathrm{p}=0.209
$$

0

$0.04(0.04)$

$$
\begin{aligned}
& 0.42(0.14) \\
& 0.17(0.12) \\
& 0.33(0.09) \\
& 0.04(0.04) \\
& \mathrm{F}=1.51 \mathrm{p}=0.233 \\
& F=4.91, p=0.035 \\
& \mathrm{~F}=1.74, \mathrm{p}=0.197
\end{aligned}
$$

$$
\begin{aligned}
& 0.47(0.17) \\
& 0.11(0.11) \\
& \mathrm{F}=1.70 \mathrm{p}=0.206 \\
& 0.14(0.10) \\
& 0.44(0.26) \\
& \mathrm{F}=1.58 \mathrm{p}=0.222 \\
& 0.14(0.06) \\
& 0.42(0.12) \\
& F=5.45, p=0.027
\end{aligned}
$$

0.215

$0.73 \quad 0.497$

$-3.76<0.001$

$\begin{array}{llll}0.65 & 0.535 & -8.48 & 0.601\end{array}$

$0.06(0.04) \quad 0.14(0.07)$ $0.04(0.04)$

$$
\mathrm{F}=1.21 \mathrm{p}=0.283 \quad \mathrm{~F}=1.10, \mathrm{p}=0.304
$$

$$
\mathrm{F}=0.57, \mathrm{p}=0.458
$$

$0.40 \quad 0.677$

$-0.3$

0.870

$\begin{array}{llll}1.60 & 0.233 & 0.71 & 0.470\end{array}$

$\begin{array}{lllll}\text { B } & 2.90 & 0.084 & -2.65 & 0.029\end{array}$

$$
\begin{array}{cc}
0.39(0.14) & 0.57(0.18) \\
0 & 0.21(0.17) \\
\mathbf{F}=\mathbf{3 . 2 1} \mathbf{p}=\mathbf{0 . 0 8 7} & \mathrm{F}=1.80, \mathbf{p}=0.191
\end{array}
$$

$$
\begin{array}{cc}
0.14(0.07) & 0.02(0.02) \\
0 & 0.04(0.04) \\
\mathrm{F}=1.84 \mathrm{p}=0.189 & \mathrm{~F}=0.16, \mathrm{p}=0.691
\end{array}
$$$$
\mathrm{F}=1.78, \mathrm{p}=0.193
$$$$
0.75 \quad 0.488
$$$$
2.33 \quad 0.416
$$$$
\begin{array}{llll}
2.12 & 0.152 & -0.36 & 0.680
\end{array}
$$ 
Table 3 continued

\begin{tabular}{|c|c|c|c|c|c|c|c|c|c|c|}
\hline \multirow{2}{*}{\multicolumn{2}{|c|}{ Red-bellied Woodpecker }} & \multicolumn{2}{|r|}{ Two-age } & \multicolumn{3}{|c|}{ Unharvested } & \multirow{2}{*}{$\frac{\mathrm{F}(\mathrm{df}=2)}{0.30}$} & \multirow{2}{*}{$\frac{p \text { trmt }}{0.743}$} & \multirow{2}{*}{$\frac{\text { BBS trend }}{2.28}$} & \multirow{2}{*}{$\frac{p}{0.003}$} \\
\hline & & & & & & & & & & \\
\hline 1994-1996 & 0 & & $0.03(0.03)$ & & 0 & & & & & \\
\hline $2005-2006$ & $0.08(0.06)$ & & 0 & & $0.08(0.06)$ & & & & & \\
\hline Contrast & $F=3.00, p=0.096$ & & $F=0.48 p=0.494$ & & $F=4.45, p=0.044$ & & & & & \\
\hline Red-eyed Vireo & & A & & $\mathrm{B}$ & & B & 2.92 & 0.083 & 1.05 & 0.076 \\
\hline 1994-1996 & $2.29(0.13)$ & & $1.86(0.13)$ & & $1.98(0.14)$ & & & & & \\
\hline $2005-2006$ & $2.38(0.20)$ & & $1.89(0.38)$ & & $1.63(0.22)$ & & & & & \\
\hline Contrast & $\mathrm{F}=0.16, \mathrm{p}=0.696$ & & $\mathrm{~F}=0.01 \mathrm{p}=0.94$ & & $\mathrm{~F}=1.73, \mathrm{p}=0.199$ & & & & & \\
\hline \multicolumn{11}{|c|}{ Rose-breasted Grosbeak } \\
\hline 1994-1996 & $0.94(0.25)$ & $\mathrm{AB}$ & $1.31(0.16)$ & A & $0.67(0.13)$ & B & 3.23 & 0.048 & -8.02 & $<0.001$ \\
\hline $2005-2006$ & $0.33(0.13)$ & & $0.28(0.22)$ & & $0.38(0.11)$ & & 0.10 & 0.905 & & \\
\hline Contrast & $F=3.28, p=0.082$ & & $=14.25 p=0.001$ & & $\mathrm{~F}=2.26, \mathrm{p}=0.144$ & & & & & \\
\hline Tufted Titmouse & & A & & $\mathrm{B}$ & & B & 6.94 & 0.007 & -0.09 & 0.872 \\
\hline 1994-1996 & $0.27(0.09)$ & & $0.06(0.04)$ & & 0 & & & & & \\
\hline $2005-2006$ & $0.21(0.11)$ & & $0.22(0.15)$ & & 0 & & & & & \\
\hline Contrast & $F=0.19, p=0.668$ & & $\mathrm{~F}=1.91 \mathrm{p}=0.181$ & & & & & & & \\
\hline Veery & & B & & A & & A & 9.72 & 0.002 & -1.86 & 0.284 \\
\hline 1994-1996 & 0 & & $1.03(0.21)$ & & $0.95(0.17)$ & & & & & \\
\hline $2005-2006$ & 0 & & $0.22(0.15)$ & & $0.29(0.11)$ & & & & & \\
\hline Contrast & & & $F=6.86 p=0.016$ & & $F=7.04, p=0.013$ & & & & & \\
\hline Wood Thrush & & & & & & & 0.93 & 0.416 & -2.22 & $<0.001$ \\
\hline 1994-1996 & $1.08(0.20)$ & & $1.31(0.24)$ & & $0.81(0.17)$ & & & & & \\
\hline $2005-2006$ & $0.54(0.18)$ & & $0.67(0.28)$ & & $0.29(0.11)$ & & & & & \\
\hline Contrast & $F=3.34, p=0.08$ & & $\mathrm{~F}=2.44 \mathrm{p}=0.133$ & & $F=4.18, p=0.05$ & & & & & \\
\hline Yellow-billed Cuck & & & & & & & 0.86 & 0.442 & -0.76 & 0.497 \\
\hline 1994-1996 & $0.11(0.11)$ & & $0.06(0.06)$ & & 0 & & & & & \\
\hline $2005-2006$ & $0.13(0.09)$ & & $0.22(0.15)$ & & $0.08(0.06)$ & & & & & \\
\hline Contrast & $\mathrm{F}=0.01, \mathrm{p}=0.93$ & & $\mathrm{~F}=1.58 \mathrm{p}=0.222$ & & $F=4.45, p=0.044$ & & & & & \\
\hline \multicolumn{11}{|c|}{ Late-successional species } \\
\hline Acadian Flycatcher & & & & & & & 1.57 & 0.238 & -1.39 & 0.329 \\
\hline 1994-1996 & $0.39(0.12)$ & & $0.19(0.08)$ & & $0.86(0.19)$ & & & & & \\
\hline $2005-2006$ & $0.28(0.13)$ & & $0.22(0.12)$ & & $0.38(0.13)$ & & & & & \\
\hline Contrast & $\mathrm{F}=0.28, \mathrm{p}=0.60$ & & $F=0.04 p=0.835$ & & $F=2.98, p=0.095$ & & & & & \\
\hline Black-and-white W & arbler & A & & $\mathrm{AB}$ & & B & 4.69 & 0.025 & -2.06 & 0.100 \\
\hline 1994-1996 & $0.50(0.11)$ & & $0.36(0.10)$ & & $0.12(0.06)$ & & & & & \\
\hline $2005-2006$ & $0.75(0.12)$ & & $0.33(0.14)$ & & $0.25(0.12)$ & & & & & \\
\hline Contrast & $\mathrm{F}=2.33, \mathrm{p}=0.14$ & & $\mathrm{~F}=0.02 \mathrm{p}=0.897$ & & $\mathrm{~F}=1.36, \mathrm{p}=0.254$ & & & & & \\
\hline Blackburnian Warb & & & & & & & 1.66 & 0.221 & 0.64 & 0.907 \\
\hline 1994-1996 & $0.03(0.03)$ & & $0.03(0.03)$ & & $0.14(0.07)$ & & & & & \\
\hline $2005-2006$ & $0.17(0.09)$ & & $0.11(0.11)$ & & $0.38(0.13)$ & & & & & \\
\hline Contrast & $\mathrm{F}=2.53, \mathrm{p}=0.125$ & & $\mathrm{~F}=0.68 \mathrm{p}=0.419$ & & $F=2.92, p=0.099$ & & & & & \\
\hline Black-throated Blue & e Warbler & $\mathrm{B}$ & & $\mathrm{B}$ & & A & 6.75 & 0.008 & -2.16 & 0.608 \\
\hline $1994-1996$ & $0.06(0.06)$ & & $0.33(0.11)$ & & $0.90(0.17)$ & & & & & \\
\hline $2005-2006$ & 0 & & $0.44(0.19)$ & & $0.67(0.13)$ & & & & & \\
\hline Contrast & $\mathrm{F}=0.67, \mathrm{p}=0.422$ & & $\mathrm{~F}=0.22 \mathrm{p}=0.643$ & & $\mathrm{~F}=0.86, \mathrm{p}=0.363$ & & & & & \\
\hline Black-throated Gree & en Warbler & & & & & & & & 3.71 & 0.026 \\
\hline 1994-1996 & $0.44(0.14)$ & $\mathrm{B}$ & $0.19(0.08)$ & B & $1.19(0.21)$ & A & 10.79 & $<0.001$ & & \\
\hline $2005-2006$ & $1.00(0.11)$ & A & $0.50(0.14)$ & B & $1.17(0.18)$ & A & 5.01 & 0.013 & & \\
\hline Contrast & $F=7.96, p=0.009$ & & $F=3.98 p=0.059$ & & $\mathrm{~F}=0.01, \mathrm{p}=0.936$ & & & & & \\
\hline Blue-headed Vireo & & & & & & & & & 6.78 & 0.082 \\
\hline 1994-1996 & $0.06(0.06)$ & B & $0.11(0.05)$ & $\mathrm{B}$ & $0.43(0.09)$ & A & 8.10 & $<0.001$ & & \\
\hline $2005-2006$ & $0.17(0.11)$ & B & $0.39(0.14)$ & $\mathrm{AB}$ & $0.75(0.23)$ & A & 3.02 & 0.064 & & \\
\hline Contrast & $\mathrm{F}=0.89, \mathrm{p}=0.355$ & & $F=5.62 p=0.027$ & & $F=3.58, p=0.069$ & & & & & \\
\hline
\end{tabular}


Table 3 continued

\begin{tabular}{|c|c|c|c|c|c|c|c|c|}
\hline & Clearcut & Two-age & Unharvested & & $F(d f=2)$ & $p$ trmt & BBS trend & $p$ \\
\hline Cerulean Warbler & & & & & 0.32 & 0.729 & -6.95 & 0.052 \\
\hline 1994-1996 & $0.06(0.06)$ & $0.14(0.07)$ & $0.24(0.10)$ & & & & & \\
\hline $2005-2006$ & $0.17(0.11)$ & 0 & 0 & & & & & \\
\hline \multicolumn{2}{|c|}{ Contrast $\mathrm{F}=0.89, \mathrm{p}=0.355$} & $\mathrm{~F}=1.96 \mathrm{p}=0.176$ & $F=3.20, p=0.084$ & & & & & \\
\hline \multicolumn{2}{|c|}{ Eastern Wood-Pewee } & & & & 1.51 & 0.251 & -4.48 & $<0.001$ \\
\hline 1994-1996 & $0.10(0.06)$ & $0.36(0.09)$ & $0.38(0.10)$ & & & & & \\
\hline $2005-2006$ & 0 & 0 & $0.04(0.04)$ & & & & & \\
\hline Contrast & $\mathrm{F}=1.93, \mathrm{p}=0.177$ & $F=7.45 p=0.012$ & $F=5.39, p=0.028$ & & & & & \\
\hline Hairy Woodpecker & & & & & 1.68 & 0.217 & 1.95 & 0.388 \\
\hline 1994-1996 & 0 & 0 & $0.05(0.03)$ & & & & & \\
\hline $2005-2006$ & $0.08(0.08)$ & 0 & $0.17(0.09)$ & & & & & \\
\hline Contrast & $\mathrm{F}=1.50, \mathrm{p}=0.232$ & & $\mathrm{~F}=2.00, \mathrm{p}=0.168$ & & & & & \\
\hline \multicolumn{2}{|c|}{ Hermit Thrush } & & & & 1.13 & 0.347 & -7.26 & 0.020 \\
\hline 1994-1996 & 0 & $0.06(0.06)$ & $0.10(0.06)$ & & & & & \\
\hline $2005-2006$ & $0.04(0.04)$ & $0.22(0.17)$ & $0.29(0.16)$ & & & & & \\
\hline Contrast & $\mathrm{F}=1.50, \mathrm{p}=0.232$ & $\mathrm{~F}=1.14 \mathrm{p}=0.297$ & $\mathrm{~F}=1.94, \mathrm{p}=0.175$ & & & & & \\
\hline \multicolumn{2}{|c|}{ Kentucky Warbler } & & & & 0.29 & 0.753 & 4.97 & 0.073 \\
\hline 1994-1996 & $0.06(0.06)$ & $0.08(0.06)$ & $0.07(0.04)$ & & & & & \\
\hline 2005-2006 & 0 & 0 & 0 & & & & & \\
\hline Contrast & $F=0.67, p=0.422$ & $\mathrm{~F}=1.04 \mathrm{p}=0.319$ & $F=1.70, p=0.203$ & & & & & \\
\hline Magnolia Warbler & & & & & 2.05 & 0.161 & 5.63 & 0.347 \\
\hline 1994-1996 & $0.69(0.20)$ & $0.33(0.15)$ & $0.17(0.06)$ & & & & & \\
\hline $2005-2006$ & $0.21(0.10)$ & $0.33(0.14)$ & $0.17(0.13)$ & & & & & \\
\hline Contrast & $F=3.34, p=0.08$ & $\mathrm{~F}=0.01 \mathrm{p}=0.927$ & $\mathrm{~F}=0.00, \mathrm{p}=1$ & & & & & \\
\hline \multicolumn{9}{|c|}{ Ovenbird } \\
\hline 1994-1996 & $1.05(0.11)$ & $0.36(0.11)$ & $0.33(0.15)$ & $\mathrm{B}$ & 9.38 & $<0.001$ & -3.00 & $<0.001$ \\
\hline $2005-2006$ & $0.67(0.15)$ & $0.39(0.16)$ & $0.50(0.28)$ & & 0.40 & 0.674 & & \\
\hline Contrast & $F=4.01, p=0.056$ & $\mathrm{~F}=0.02 \mathrm{p}=0.889$ & $\mathrm{~F}=0.30, \mathrm{p}=0.589$ & & & & & \\
\hline \multicolumn{2}{|c|}{ Pileated Woodpecker } & & & & 1.04 & 0.376 & -1.11 & 0.219 \\
\hline 1994-1996 & $0.08(0.06)$ & $0.03(0.03)$ & $0.14(0.05)$ & & & & & \\
\hline $2005-2006$ & $0.08(0.08)$ & $0.06(0.06)$ & $0.08(0.06)$ & & & & & \\
\hline Contrast & $\mathrm{F}=0.00, \mathrm{p}=1$ & $F=0.16 p=0.695$ & $\mathrm{~F}=0.53, \mathrm{p}=0.471$ & & & & & \\
\hline \multicolumn{2}{|l|}{ Scarlet Tanager } & & & & 1.13 & 0.349 & 0.01 & 0.989 \\
\hline 1994-1996 & $0.64(0.16)$ & $0.22(0.09)$ & $0.64(0.12)$ & & & & & \\
\hline $2005-2006$ & $0.58(0.16)$ & $0.61(0.23)$ & $0.42(0.08)$ & & & & & \\
\hline Contrast & $\mathrm{F}=0.06, \mathrm{p}=0.811$ & $F=3.01 p=0.097$ & $\mathrm{~F}=1.79, \mathrm{p}=0.192$ & & & & & \\
\hline \multicolumn{2}{|c|}{ White-breasted Nuthatch } & & & & 0.80 & 0.468 & 3.06 & 0.027 \\
\hline 1994-1996 & 0 & $0.17(0.08)$ & $0.19(0.11)$ & & & & & \\
\hline $2005-2006$ & $0.08(0.08)$ & $0.06(0.06)$ & $0.04(0.04)$ & & & & & \\
\hline Contrast & $\mathrm{F}=1.50, \mathrm{p}=0.232$ & $\mathrm{~F}=1.10 \mathrm{p}=0.305$ & $\mathrm{~F}=1.11, \mathrm{p}=0.302$ & & & & & \\
\hline \multicolumn{2}{|c|}{ Winter Wren } & $\mathrm{B}$ & $\mathrm{B}$ & A & 5.65 & 0.014 & 4.39 & 0.873 \\
\hline 1994-1996 & 0 & $0.08(0.06)$ & $0.31(0.08)$ & & & & & \\
\hline $2005-2006$ & 0 & $0.28(0.19)$ & $0.42(0.12)$ & & & & & \\
\hline Contrast & & $F=1.62 p=0.216$ & $\mathrm{~F}=0.64, \mathrm{p}=0.43$ & & & & & \\
\hline
\end{tabular}

\footnotetext{
${ }^{a}$ Years are tested separately when there was a significant treatment by year interaction effect.

${ }^{b}$ For a given species or guild means with a different letter differ significantly; Waller-Duncan k-ratio t-tests, $p<0.10$.

${ }^{c}$ Contrasts are between old data collected in 1994-1996 and new data from 2005-2006.

${ }^{d}$ Breeding Bird Survey (BBS) annual trend (\% difference) and probability in the Ridge and Valley physiographic region based from Sauer et al.(2005) from 1994-2005.
} 
Table 4. Mean per stand ( \pm SE) for habitat variables (prior to transformation) measured from 1994-1996 and from 2005-2006 in 0.04 ha plots around point count stations in three treatments on the Monongahela National Forest, West Virginia.

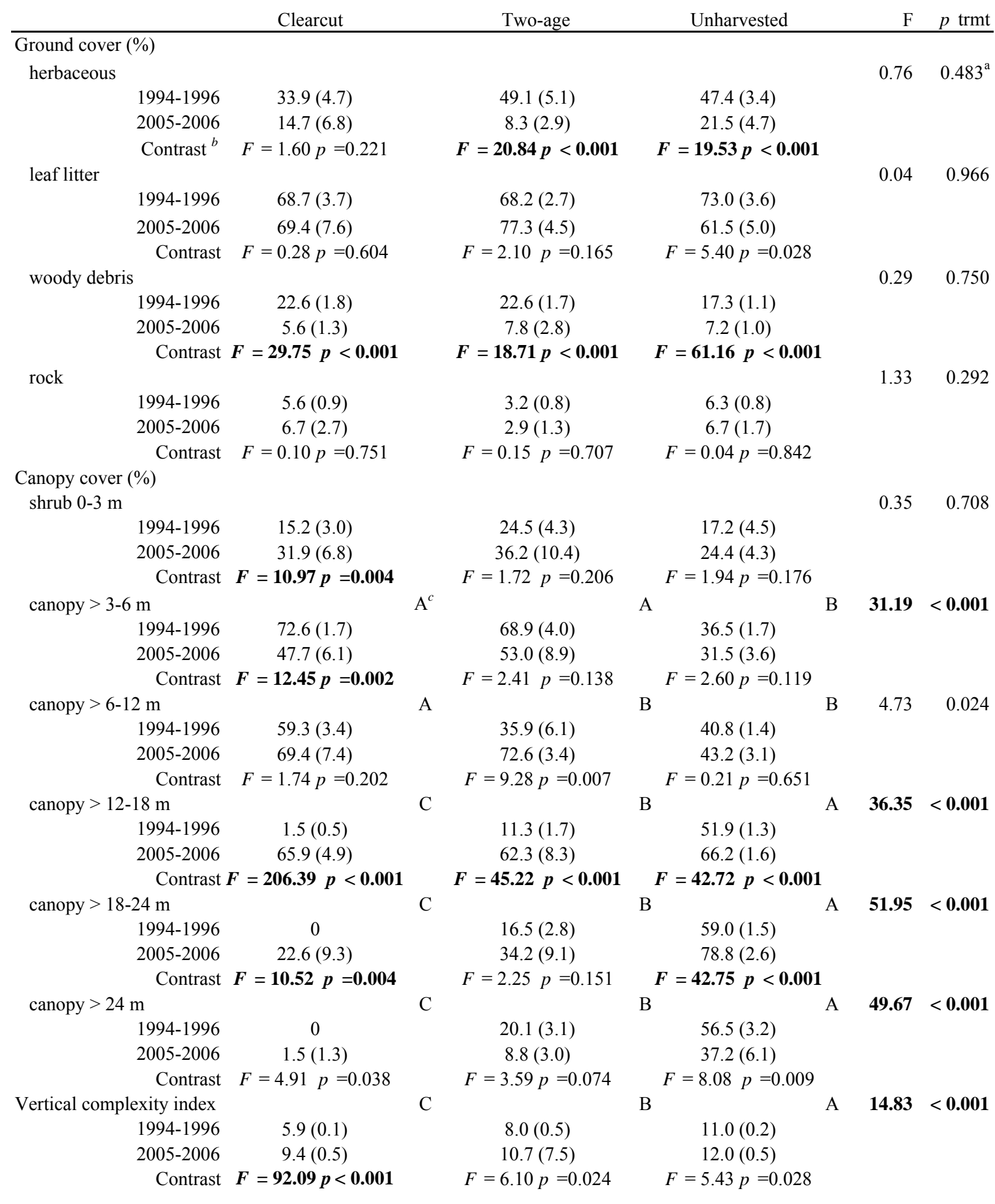


Table 4 (continued)

\begin{tabular}{|c|c|c|c|c|c|c|c|}
\hline & Clearcut & & Two-age & Unharvested & & $\mathrm{F}$ & $p$ trmt \\
\hline \multicolumn{8}{|l|}{ Number of stems (dbh class) } \\
\hline saplings $0-7.6 \mathrm{~cm}$ & & B & & A & $\mathrm{C}$ & 25.52 & $<0.001$ \\
\hline 1994-1996 & $128.6(5.1)$ & & $161.2(14.1)$ & $22.3(1.3)$ & & & \\
\hline $2005-2006$ & $43.3(10.7)$ & & $36.3(10.1)$ & $17.8(6.4)$ & & & \\
\hline Contrast & $F=47.95 p<0.001$ & & $F=22.23 p<0.001$ & $F=0.94 p=0.342$ & & & \\
\hline poles $7.7-15.2 \mathrm{~cm}$ & & A & & B & $\mathrm{C}$ & 30.31 & $<0.001$ \\
\hline 1994-1996 & $32.7(2.1)$ & & $16.0(2.4)$ & $6.7(0.5)$ & & & \\
\hline $2005-2006$ & $21.5(1.6)$ & & $18.6(3.4)$ & $4.0(0.6)$ & & & \\
\hline Contrast & $F=17.32 p<0.001$ & & $F=0.68 p=0.422$ & $F=13.02 p=0.001$ & & & \\
\hline trees $15.3-22.9 \mathrm{~cm}$ & & & & & & 1.41 & 0.272 \\
\hline 1994-1996 & $2.0(0.2)$ & & $1.4(0.4)$ & $3.5(0.4)$ & & & \\
\hline $2005-2006$ & $5.1(1.0)$ & & $4.3(1.3)$ & $2.5(0.5)$ & & & \\
\hline Contrast & $F=62.83 p<0.001$ & & $F=8.70 p=0.009$ & $F=1.61 p=0.216$ & & & \\
\hline trees $23-30.5 \mathrm{~cm}$ & & B & & B & A & 6.66 & 0.008 \\
\hline 1994-1996 & $0.07(0.03)$ & & $0.4(0.3)$ & $2.3(0.3)$ & & & \\
\hline $2005-2006$ & $2.2(0.5)$ & & $1.8(0.4)$ & $2.4(0.4)$ & & & \\
\hline Contrast & $F=20.26 p<0.001$ & & $F=3.79 p=0.067$ & $F=0.02 p=0.881$ & & & \\
\hline trees $30.5-38.1 \mathrm{~cm}$ & & B & & 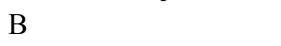 & A & 11.32 & $<0.001$ \\
\hline 1994-1996 & 0 & & $0.4(0.2)$ & $1.7(0.2)$ & & & \\
\hline $2005-2006$ & $0.2(0.1)$ & & $0.6(0.3)$ & $1.8(0.2)$ & & & \\
\hline Contrast & $F=7.59 p=0.012$ & & $F=0.80 p=0.384$ & $F=0.21 p=0.65$ & & & \\
\hline trees $>38.1 \mathrm{~cm}$ & & $\mathrm{C}$ & & B & A & 35.47 & $<0.001$ \\
\hline 1994-1996 & 0 & & $1.3(0.2)$ & $3.5(0.3)$ & & & \\
\hline $2005-2006$ & $0.3(0.1)$ & & $1.7(0.4)$ & $4.5(0.4)$ & & & \\
\hline Contrast & $F=2.24 p=0.150$ & & $F=1.67 p=0.212$ & $F=4.11 p=0.053$ & & & \\
\hline sum of all trees $>15.3 \mathrm{~cm}$ & & B & & B & A & 16.14 & $<0.001$ \\
\hline 1994-1996 & $2.0(0.2)$ & & $3.5(0.8)$ & $11.0(0.7)$ & & & \\
\hline $2005-2006$ & $7.7(1.1)$ & & $8.4(1.4)$ & $11.1(1.0)$ & & & \\
\hline Contrast & $F=81.53 p<0.001$ & & $F=8.92 p=0.008$ & $F=0.08 p=0.786$ & & & \\
\hline \multicolumn{8}{|c|}{ Number of snags (DBH class) } \\
\hline $7.7-15.2 \mathrm{~cm}$ & & & & & & 1.47 & 0.260 \\
\hline 1994-1996 & $1.5(0.3)$ & & $0.5(0.1)$ & $1.5(0.3)$ & & & \\
\hline $2005-2006$ & $1.1(0.4)$ & & $0.8(0.5)$ & $0.3(0.1)$ & & & \\
\hline Contrast & $F=0.01 p=0.911$ & & $F=0.28 p=0.601$ & $F=6.37 p=0.018$ & & & \\
\hline sum of all snags $>15.3 \mathrm{~cm}$ & & B & & B & A & 20.84 & $<0.001$ \\
\hline 1994-1996 & $0.04(0.02)$ & & $0.12(0.07)$ & $1.4(0.1)$ & & & \\
\hline $2005-2006$ & $0.10(0.05)$ & & $0.3(0.1)$ & $0.8(0.2)$ & & & \\
\hline Contrast & $F=5.33 p=0.032$ & & $F=0.54 p=0.474$ & $F=5.53 p=0.027$ & & & \\
\hline
\end{tabular}

${ }^{a}$ Contrasts are between old data collected in 1994-1996 and new data from 2005-2006.

${ }^{b}$ After experiment-wide Bonferroni corrections, tests are significant at the 0.005 alpha level.

${ }^{c}$ For a given metric means with a different letter differ significantly; Waller-Duncan k-ratio t-tests. 
Appendix 1. Classifications of bird species detected by point counts in north-central West Virginia during 1994-1996 and 2005-2006 based on breeding habitat associations and migratory strategy.

\begin{tabular}{|c|c|c|c|}
\hline Species & Scientific name & Breeding habitat & Migratory strategy \\
\hline Chestnut-sided Warbler & Dendroica pensylvanica & Early-successional & Nearctic-Neotropical \\
\hline Golden-winged Warbler & Vermivora chrysoptera & Early-successional & Nearctic-Neotropical \\
\hline Indigo Bunting & Passerina cyanea & Early-successional & Nearctic-Neotropical \\
\hline Mourning Warbler & Oporornis philadelphia & Early-successional & Nearctic-Neotropical \\
\hline White-eyed Vireo & Vireo griseus & Early-successional & Nearctic-Neotropical \\
\hline Mourning Dove & Zenaida macroura & Early-successional & Permanent Resident \\
\hline Northern Cardinal & Cardinalis cardinalis & Early-successional & Permanent Resident \\
\hline American Goldfinch & Carduelis tristis & Early-successional & Short-distance \\
\hline Brown Thrasher & Toxostoma rufum & Early-successional & Short-distance \\
\hline Common Yellowthroat & Geothlypis trichas & Early-successional & Short-distance \\
\hline Eastern Towhee & Pipilo erythrophthalmus & Early-successional & Short-distance \\
\hline Gray Catbird & Dumetella carolinensis & Early-successional & Short-distance \\
\hline Northern Mockingbird & Mimus polyglottos & Early-successional & Short-distance \\
\hline American Redstart & Setophaga ruticilla & Generalist & Nearctic-Neotropical \\
\hline Baltimore Oriole & Icterus galbula & Generalist & Nearctic-Neotropical \\
\hline Black-billed Cuckoo & Coccyzus erythropthalmus & Generalist & Nearctic-Neotropical \\
\hline Canada Warbler & Wilsonia canadensis & Generalist & Nearctic-Neotropical \\
\hline Great Crested Flycatcher & Myiarchus crinitus & Generalist & Nearctic-Neotropical \\
\hline Hooded Warbler & Wilsonia citrina & Generalist & Nearctic-Neotropical \\
\hline Northern Parula & Parula americana & Generalist & Nearctic-Neotropical \\
\hline Red-eyed Vireo & Vireo olivaceus & Generalist & Nearctic-Neotropical \\
\hline Rose-breasted Grosbeak & Pheucticus ludovicianus & Generalist & Nearctic-Neotropical \\
\hline Ruby-throated Hummingbird & Archilochus colubris & Generalist & Nearctic-Neotropical \\
\hline Veery & Catharus fuscescens & Generalist & Nearctic-Neotropical \\
\hline Wood Thrush & Hylocichla mustelina & Generalist & Nearctic-Neotropical \\
\hline Yellow-billed Cuckoo & Coccyzus americanus & Generalist & Nearctic-Neotropical \\
\hline Yellow-throated Vireo & Vireo flavifrons & Generalist & Nearctic-Neotropical \\
\hline Black-capped Chickadee & Poecile atricapilla & Generalist & Permanent Resident \\
\hline Blue Jay & Cyanocitta cristata & Generalist & Permanent Resident \\
\hline Downy Woodpecker & Picoides pubescens & Generalist & Permanent Resident \\
\hline Northern Flicker & Colaptes auratus & Generalist & Permanent Resident \\
\hline Red-bellied Woodpecker & Melanerpes carolinus & Generalist & Permanent Resident \\
\hline Tufted Titmouse & Baeolophus bicolor & Generalist & Permanent Resident \\
\hline American Robin & Turdus migratorius & Generalist & Short-distance \\
\hline Blue-gray Gnatcatcher & Polioptila caerulea & Generalist & Short-distance \\
\hline Brown-headed Cowbird & Molothrus ater & Generalist & Short-distance \\
\hline Cedar Waxwing & Bombycilla cedrorum & Generalist & Short-distance \\
\hline Dark-eyed Junco & Junco hyemalis & Generalist & Short-distance \\
\hline Acadian Flycatcher & Empidonax virescens & Late-successional & Nearctic-Neotropical \\
\hline Black-and-white Warbler & Mniotilta varia & Late-successional & Nearctic-Neotropical \\
\hline Blackburnian Warbler & Dendroica fusca & Late-successional & Nearctic-Neotropical \\
\hline Black-throated Blue Warbler & Dendroica caerulescens & Late-successional & Nearctic-Neotropical \\
\hline Black-throated Green Warbler & Dendroica virens & Late-successional & Nearctic-Neotropical \\
\hline Blue-headed Vireo & Vireo solitarius & Late-successional & Nearctic-Neotropical \\
\hline Cerulean Warbler & Dendroica cerulea & Late-successional & Nearctic-Neotropical \\
\hline Eastern Wood-Pewee & Contopus virens & Late-successional & Nearctic-Neotropical \\
\hline Kentucky Warbler & Oporornis formosus & Late-successional & Nearctic-Neotropical \\
\hline Least Flycatcher & Empidonax minimus & Late-successional & Nearctic-Neotropical \\
\hline Louisiana Waterthrush & Seiurus motacilla & Late-successional & Nearctic-Neotropical \\
\hline Magnolia Warbler & Dendroica magnolia & Late-successional & Nearctic-Neotropical \\
\hline Ovenbird & Seiurus aurocapillus & Late-successional & Nearctic-Neotropical \\
\hline Scarlet Tanager & Piranga olivacea & Late-successional & Nearctic-Neotropical \\
\hline Worm-eating Warbler & Helmitheros vermivorus & Late-successional & Nearctic-Neotropical \\
\hline Brown Creeper & Certhia americana & Late-successional & Permanent Resident \\
\hline Hairy Woodpecker & Picoides villosus & Late-successional & Permanent Resident \\
\hline Pileated Woodpecker & Dryocopus pileatus & Late-successional & Permanent Resident \\
\hline Red-breasted Nuthatch & Sitta canadensis & Late-successional & Permanent Resident \\
\hline White-breasted Nuthatch & Sitta carolinensis & Late-successional & Permanent Resident \\
\hline Golden-crowned Kinglet & Regulus satrapa & Late-successional & Short-distance \\
\hline Hermit Thrush & Catharus guttatus & Late-successional & Short-distance \\
\hline Winter Wren & Troglodytes troglodytes & Late-successional & Short-distance \\
\hline
\end{tabular}


Appendix 2. Mean relative bird abundance, species richness, and diversity ( \pm SE) per stand (100-m radius plots) in 3 treatments during 1994-1996 and 2005-2006 on the Monongahela National Forest, West Virginia.

\begin{tabular}{|c|c|c|c|c|c|c|c|c|}
\hline & & Clearcut & & Two-age & Unharvested & & $F(d f=2)$ & $p$ trmt \\
\hline \multirow[t]{7}{*}{ Total bird abundance } & & & & & & & 0.09 & 0.912 \\
\hline & 1994 & $14.19(1.36)$ & & $16.33(0.68)$ & $14.00(1.41)$ & & 1.09 & $0.359^{a}$ \\
\hline & 1995 & 15.17 (1.49) & & $17.00(0.47)$ & $15.79(1.03)$ & & 0.71 & 0.506 \\
\hline & 1996 & $11.25(0.87)$ & & $11.58(0.33)$ & $13.29(1.10)$ & & 1.64 & 0.225 \\
\hline & 2005 & $11.83(0.53)$ & A & $8.38(0.80)$ & $11.50(0.97)$ & A & 4.85 & 0.027 \\
\hline & 2006 & $12.83(1.22)$ & & $11.10(1.17)$ & $11.67(0.57)$ & & 0.75 & 0.491 \\
\hline & Contrast ${ }^{c}$ & $\mathrm{~F}=1.32, \mathrm{p}=0.261$ & & $=61.39 p<0.001$ & $F=7.59, p=0.01$ & & & \\
\hline \multirow[t]{7}{*}{ Species richness } & & & & & & & 0.15 & 0.864 \\
\hline & 1994 & $9.81(1.09)$ & & $11.50(0.70)$ & $9.50(1.21)$ & & 1.04 & 0.375 \\
\hline & 1995 & $11.08(0.99)$ & & $12.75(0.66)$ & $11.93(0.93)$ & & 0.85 & 0.447 \\
\hline & 1996 & $8.75(0.63)$ & & $8.67(0.57)$ & $9.79(0.89)$ & & 0.75 & 0.486 \\
\hline & 2005 & $9.33(0.57)$ & A & $6.88(0.77)$ & $9.75(0.50)$ & A & 5.82 & 0.016 \\
\hline & 2006 & $10.00(1.06)$ & & $8.40(0.99)$ & $9.08(0.33)$ & & 0.88 & 0.438 \\
\hline & Contrast & $\mathrm{F}=0.07, \mathrm{p}=0.797$ & & $=22.71 \mathrm{p}<0.001$ & $\mathrm{~F}=1.48, \mathrm{p}=0.234$ & & & \\
\hline \multirow[t]{7}{*}{ Shannon diversity } & & & & & & & 0.20 & 0.821 \\
\hline & 1994 & $2.13(0.13)$ & & $2.34(0.07)$ & $2.11(0.13)$ & & 1.18 & 0.332 \\
\hline & 1995 & $2.31(0.10)$ & & $2.45(0.07)$ & $2.35(0.07)$ & & 0.71 & 0.505 \\
\hline & 1996 & $2.07(0.08)$ & & $2.08(0.07)$ & $2.16(0.09)$ & & 0.35 & 0.711 \\
\hline & 2005 & $2.14(0.07)$ & A & $1.87(0.11)$ & $2.22(0.05)$ & A & 5.78 & 0.016 \\
\hline & 2006 & $2.16(0.11)$ & & $1.99(0.14)$ & $2.11(0.04)$ & & 0.76 & 0.487 \\
\hline & Contrast & $\mathrm{F}=0.06, \mathrm{p}=0.812$ & & $=16.92 p<0.001$ & $\mathrm{~F}=0.22, \mathrm{p}=0.64$ & & & \\
\hline \multicolumn{9}{|l|}{ Guild abundance } \\
\hline \multirow[t]{7}{*}{ early-successional } & & & $\mathrm{AB}$ & & A & $\mathrm{B}$ & 3.84 & 0.043 \\
\hline & 1994 & $2.08(0.57)$ & $\mathrm{B}$ & $3.92(0.79)$ & $0.43(0.28)$ & $\mathrm{C}$ & 9.94 & 0.002 \\
\hline & 1995 & $1.50(0.55)$ & B & $3.58(1.23)$ & $0.79(0.29)$ & $\mathrm{B}$ & 3.70 & 0.048 \\
\hline & 1996 & $1.33(0.42)$ & & $1.75(0.73)$ & $0.93(0.38)$ & & 0.64 & 0.542 \\
\hline & 2005 & $0.83(0.31)$ & & $0.13(0.13)$ & $0.58(0.20)$ & & 1.86 & 0.195 \\
\hline & 2006 & $0.75(0.31)$ & & $0.30(0.20)$ & $0.17(0.11)$ & & 1.94 & 0.181 \\
\hline & Contrast & $F=4.34, p=0.048$ & & $=13.36 p=0.001$ & $\mathrm{~F}=1.71, \mathrm{p}=0.202$ & & & \\
\hline \multirow[t]{7}{*}{ generalist } & & & & & & & 0.94 & 0.412 \\
\hline & 1994 & $8.00(1.16)$ & & $9.50(1.03)$ & $6.93(1.00)$ & & & \\
\hline & 1995 & $8.33(1.23)$ & & $9.50(0.91)$ & $7.50(0.83)$ & & & \\
\hline & 1996 & $6.33(0.70)$ & & $7.00(0.47)$ & $6.64(0.80)$ & & & \\
\hline & 2005 & $7.08(0.76)$ & & $5.50(1.32)$ & $5.00(0.47)$ & & & \\
\hline & 2006 & $6.83(0.91)$ & & $5.70(0.70)$ & $5.33(0.53)$ & & & \\
\hline & Contrast & $\mathrm{F}=0.45, \mathrm{p}=0.509$ & & $=13.06 \mathrm{p}=0.002$ & $F=6.56, p=0.016$ & & & \\
\hline \multirow[t]{7}{*}{ late-successional } & & & B & & $\mathrm{B}$ & A & 11.49 & $<0.001$ \\
\hline & 1994 & $3.97(0.67)$ & & $2.83(0.57)$ & $6.57(0.91)$ & & & \\
\hline & 1995 & $5.33(0.49)$ & & $3.92(0.61)$ & $7.29(0.75)$ & & & \\
\hline & 1996 & $3.42(0.33)$ & & $2.83(0.53)$ & $5.64(0.58)$ & & & \\
\hline & 2005 & $3.92(0.84)$ & & $2.75(1.03)$ & $5.92(0.97)$ & & & \\
\hline & 2006 & $4.92(0.58)$ & & $5.10(0.81)$ & $6.00(0.88)$ & & & \\
\hline & Contrast & $\mathrm{F}=0.1, \mathrm{p}=0.754$ & & $\mathrm{~F}=1.26 \mathrm{p}=0.273$ & $\mathrm{~F}=0.51, \mathrm{p}=0.483$ & & & \\
\hline \multirow[t]{7}{*}{ Neotropical migrants } & & & & & & & 0.43 & 0.659 \\
\hline & 1994 & $11.00(0.96)$ & & $12.42(0.66)$ & $12.29(0.94)$ & & & \\
\hline & 1995 & $12.42(1.29)$ & & $12.75(0.77)$ & $12.79(0.78)$ & & & \\
\hline & 1996 & $9.42(0.64)$ & & $9.75(0.63)$ & $11.21(0.93)$ & & & \\
\hline & 2005 & $9.08(1.00)$ & & $6.00(0.82)$ & $8.25(1.16)$ & & & \\
\hline & 2006 & $9.92(0.95)$ & & $8.00(1.33)$ & $8.42(0.85)$ & & & \\
\hline & Contrast & $\mathrm{F}=2.55, \mathrm{p}=0.123$ & & $=32.58 \mathrm{p}<0.001$ & $F=18.75, p<0.001$ & & & \\
\hline
\end{tabular}


Appendix 2 continued

\begin{tabular}{|c|c|c|c|c|c|c|c|c|c|}
\hline & & Clearcut & & Two-age & & Unharvested & & $F(d f=2)$ & $p$ trmt \\
\hline \multirow[t]{7}{*}{ short-distance migrant } & nts & & & & & & & 1.66 & 0.222 \\
\hline & 1994 & $1.53(0.37)$ & $\mathrm{B}$ & $3.00(0.79)$ & $\mathrm{A}$ & $1.00(0.41)$ & B & 3.68 & 0.049 \\
\hline & 1995 & $1.25(0.40)$ & & $2.75(0.79)$ & & $2.07(0.40)$ & & 1.78 & 0.201 \\
\hline & 1996 & $0.58(0.27)$ & & $1.17(0.48)$ & & $1.21(0.18)$ & & 1.17 & 0.336 \\
\hline & 2005 & $1.25(0.40)$ & & $1.25(0.48)$ & & $2.25(0.57)$ & & 1.39 & 0.283 \\
\hline & 2006 & $1.00(0.37)$ & & $1.80(0.86)$ & & $2.17(0.61)$ & & 0.99 & 0.397 \\
\hline & Contrast & $\mathrm{F}=0.00, \mathrm{p}=0.989$ & & $F=1.29 p=0.268$ & & $F=3.58, p=0.069$ & & & \\
\hline \multirow[t]{7}{*}{ permanent residents } & & & A & & $\mathrm{AB}$ & & B & 4.18 & 0.035 \\
\hline & 1994 & $1.53(0.47)$ & & $0.83(0.28)$ & & $0.64(0.32)$ & & & \\
\hline & 1995 & $1.50(0.68)$ & & $1.50(0.32)$ & & $0.71(0.26)$ & & & \\
\hline & 1996 & $1.08(0.45)$ & & $0.67(0.31)$ & & $0.79(0.26)$ & & & \\
\hline & 2005 & $1.50(0.50)$ & & $1.13(0.43)$ & & $1.00(0.34)$ & & & \\
\hline & 2006 & $1.58(0.33)$ & & $1.30(0.44)$ & & $0.92(0.40)$ & & & \\
\hline & Contrast & $\mathrm{F}=0.14, \mathrm{p}=0.711$ & & $F=0.42 p=0.525$ & & $F=0.69, p=0.413$ & & & \\
\hline
\end{tabular}

Early-successional species

American Goldfinch

$\begin{array}{cc}1994 & 0 \\ 1995 & 0 \\ 1996 & 0 \\ 2005 & 0.08(0.08) \\ 2006 & 0\end{array}$

Brown Thrasher

$1994 \quad 0$

$1995 \quad 0$

$1996 \quad 0$

$2005 \quad 0$

Chestnut-sided Warbler

2006

0

\section{Chestnut-sided Warbler}

1994

1995

1996

2005

$2006 \quad 0.08(0.08)$

Contrast $\mathrm{F}=1.50, \mathrm{p}=0.232$

Common Yellowthroat

$\begin{array}{ll}1994 & 0 \\ 1995 & 0 \\ 1996 & 0 \\ 2005 & 0 \\ 2006 & 0\end{array}$

Eastern Towhee

$$
\begin{array}{rl}
1994 & 0.50(0.18) \\
1995 & 0.67(0.33) \\
1996 & 0.33(0.21) \\
2005 & 0.08(0.08) \\
2006 & 0.17(0.17) \\
\text { Contrast } \mathbf{F}=\mathbf{3 . 7 7 ,} \mathbf{p}=\mathbf{0 . 0 6 3}
\end{array}
$$

Gray Catbird

\begin{tabular}{|c|c|c|c|}
\hline & & 0.89 & 0.429 \\
\hline $0.58(0.15)$ & $0.14(0.14)$ & & \\
\hline $0.67(0.36)$ & $0.21(0.15)$ & & \\
\hline 0 & $0.29(0.15)$ & & \\
\hline 0 & $0.25(0.11)$ & & \\
\hline $0.10(0.10)$ & 0 & & \\
\hline$F=3.71 p=0.067$ & $\mathrm{~F}=0.55, \mathrm{p}=0.464$ & & \\
\hline & & 2.22 & 0.141 \\
\hline $0.33(0.17)$ & 0 & & \\
\hline $0.33(0.21)$ & 0 & & \\
\hline 0 & 0 & & \\
\hline $0.13(0.13)$ & $0.25(0.17)$ & & \\
\hline 0 & 0 & & \\
\hline $\mathrm{F}=1.42 \mathrm{p}=0.246$ & $F=3.82, p=0.061$ & & \\
\hline
\end{tabular}

$\begin{array}{cc}1994 & 0.08(0.08) \\ 1995 & 0 \\ 1996 & 0 \\ 2005 & 0.17(0.17) \\ 2006 & 0 \\ \text { Contrast } \mathrm{F}=0.53, \mathrm{p}=0.472\end{array}$

$\begin{array}{cc}0 & 0 \\ 0 & 0.07(0.07) \\ 0 & 0 \\ 0 & 0 \\ 0.20(0.20) & 0\end{array}$

$0.08(0.08)$
$0.17(0.17)$
0
0
0

$\begin{array}{ccccccc}\text { B } & & \text { A } & & \text { B } & \mathbf{5 . 3 5} & \mathbf{0 . 0 1 7} \\ \text { B } & 1.50(0.37) & \text { A } & 0.07(0.07) & \text { B } & \mathbf{1 6 . 6 8} & <\mathbf{0 . 0 0 1} \\ & 0.92(0.64) & & 0 & & 2.26 & 0.137 \\ \text { B } & 0.92(0.49) & \text { A } & 0 & \text { B } & 3.83 & \mathbf{0 . 0 4 4} \\ & 0 & & 0 & & . & . \\ & 0 & & 0.08(0.08) & 0.41 & 0.67\end{array}$

$\begin{array}{cc}0.17(0.17) & 0 \\ 0.17(0.17) & 0 \\ 0 & 0 \\ 0 & 0 \\ 0 & 0\end{array}$


Appendix 2 continued

Clearcut

Indigo Bunting

Mourning Dove$$
\text { Contrast } \mathbf{F}=\mathbf{3 . 4 8}, \mathrm{p}=\mathbf{0 . 0 7 4}
$$

$\begin{array}{cc}1994 & 0 \\ 1995 & 0.08(0.08) \\ 1996 & 0 \\ 2005 & 0 \\ 2006 & 0.17(0.17)\end{array}$

Mourning Warbler

$\begin{array}{ll}1994 & 0 \\ 1995 & 0 \\ 1996 & 0 \\ 2005 & 0 \\ 2006 & 0\end{array}$

Northern Cardinal

$$
\begin{array}{cc}
1994 & 0.33(0.17) \\
1995 & 0.17(0.11) \\
1996 & 0.25(0.17) \\
2005 & 0.17(0.17) \\
2006 & 0 \\
\text { Contrast } F=1.74, p=0.199
\end{array}
$$

Northern Mockingbird

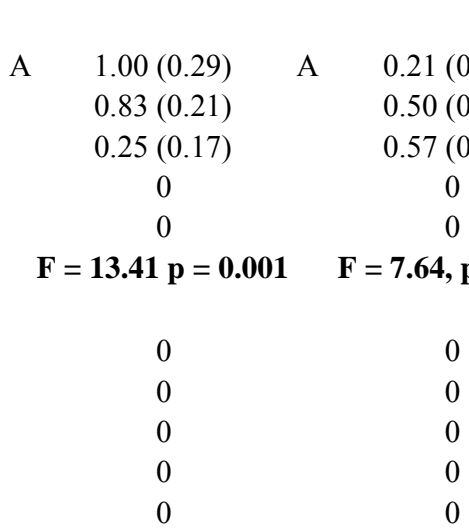

$\begin{array}{cc}1994 & 0 \\ 1995 & 0 \\ 1996 & 0.08(0.08) \\ 2005 & 0 \\ 2006 & 0\end{array}$

Generalist species

American Redstart

American Robin

$\begin{array}{cc}1994 & 0.17(0.17) \\ 1995 & 0.83(0.48) \\ 1996 & 0.58(0.49) \\ 2005 & 1.58(0.42) \\ 2006 & 0.92(0.33) \\ \text { Contrast } \mathbf{F}=\mathbf{4 . 0 3}, \mathbf{p}=\mathbf{0 . 0 5 6}\end{array}$

$$
\begin{array}{cc}
1994 & 0.08(0.08) \\
1995 & 0 \\
1996 & 0 \\
2005 & 0.33(0.33) \\
2006 & 0.17(0.17)
\end{array}
$$$$
\text { Contrast } \mathrm{F}=2.03, \mathrm{p}=0.167
$$

Baltimore Oriole

$\begin{array}{cc}1994 & 0 \\ 1995 & 0 \\ 1996 & 0 \\ 2005 & 0 \\ 2006 & 0.17(0.17)\end{array}$

Two-age

$$
\begin{gathered}
0.17(0.17) \\
0.25(0.17) \\
0.17(0.17) \\
0 \\
0
\end{gathered}
$$

Unharvested

$\mathrm{F}(\mathrm{df}=2) \quad p$ trmt

$1.22 \quad 0.322$

$3.77 \quad 0.046$

$0.67 \quad 0.526$

$0.67 \quad 0.527$

$2.03 \quad 0.171$

$2.26 \quad 0.141$

$d$

0
0
0
0
0

0

0
0
$0.07(0.07)$
$0.08(0.08)$
$0.08(0.08)$

2.04

0.163

$\begin{array}{cc}0.08(0.08) & 0 \\ 0.25(0.17) & 0 \\ 0.42(0.33) & 0 \\ 0 & 0 \\ 0 & 0 \\ =1.91 \mathrm{p}=0.181 & \end{array}$

$\mathrm{F}=1.91 \mathrm{p}=0.181$

0
0
0
0
0

$\begin{array}{ll}0 & 0 \\ 0 & 0 \\ 0 & 0 \\ 0 & 0 \\ 0 & 0\end{array}$


Appendix 2 continued

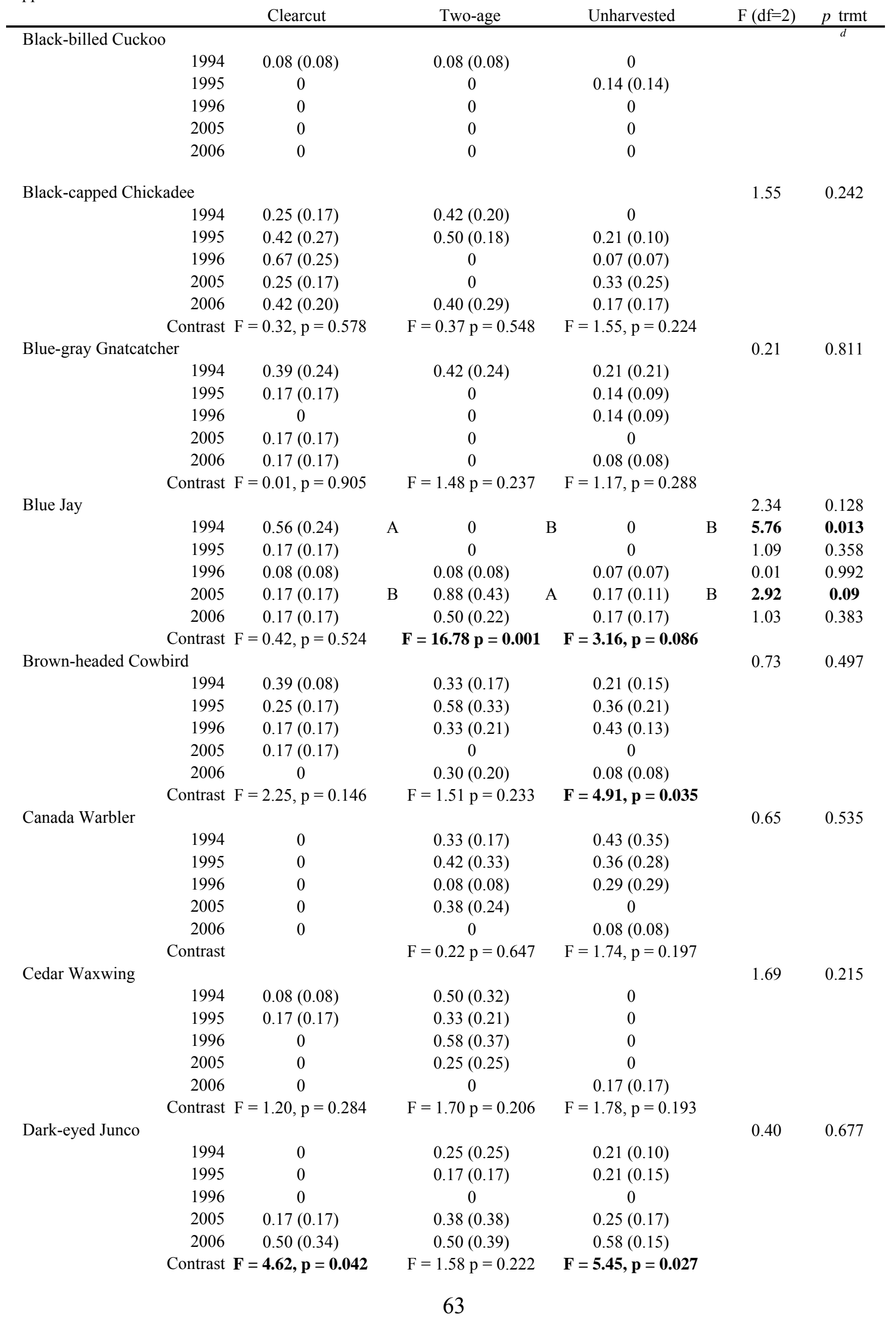


Appendix 2 continued

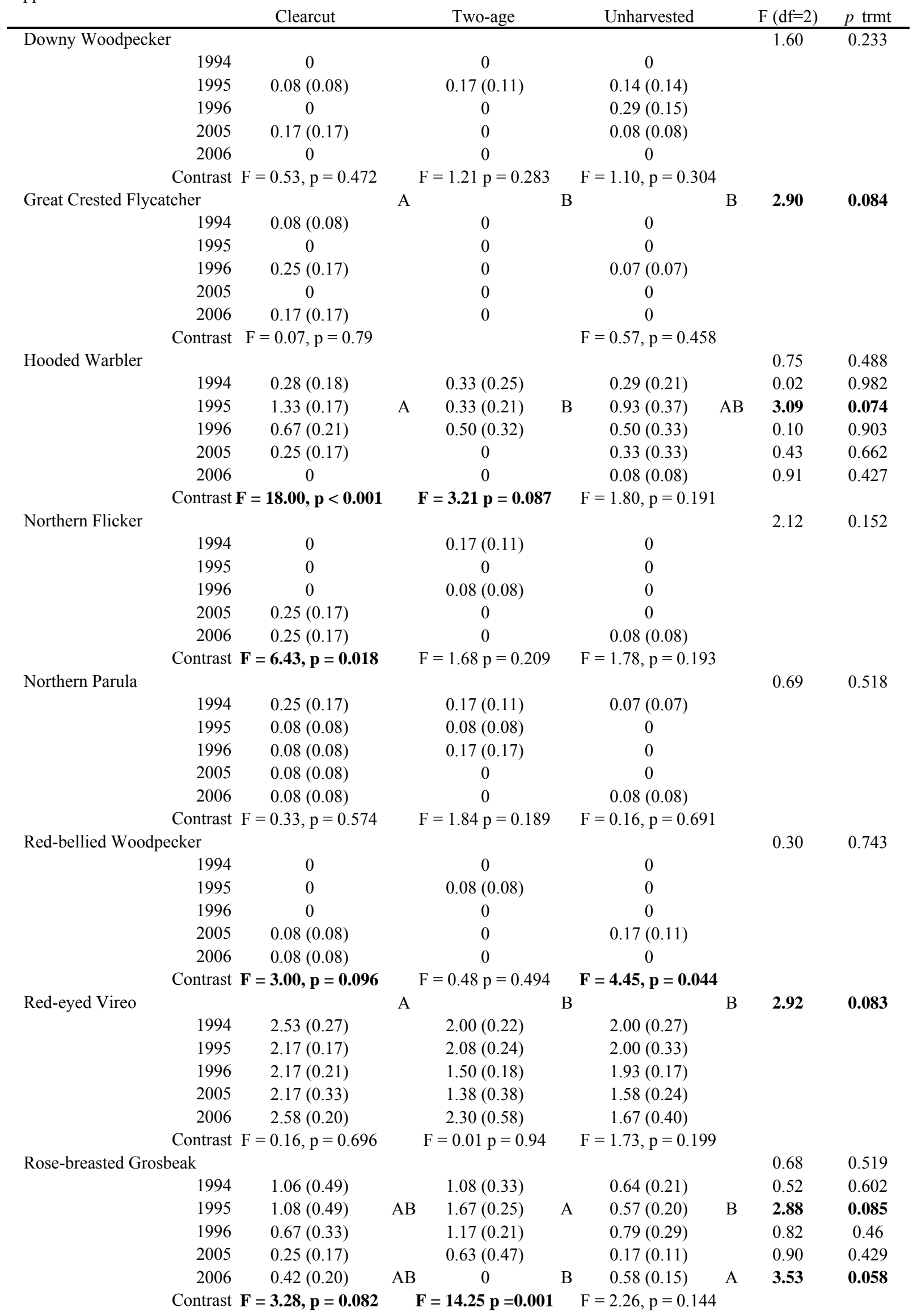


Appendix 2 continued

Clearcut

Two-age

Unharvested

$\mathrm{F}(\mathrm{df}=2) \quad p$ trmt

Ruby-throated Hummingbird

$\begin{array}{ll}1994 & 0 \\ 1995 & 0 \\ 1996 & 0 \\ 2005 & 0 \\ 2006 & 0\end{array}$

Tufted Titmouse

1994

1995

1996

2005

2006

$0.39(0.15)$

$0.33(0.21)$

$0.08(0.08)$

$0.42(0.20)$

Contrast $\mathrm{F}=0.19, \mathrm{p}=0.668$

Veery

$$
\text { Contrast } F=0.19, p=0.668
$$

Veery

$\begin{array}{rl}1994 & 0 \\ 1995 & 0 \\ 1996 & 0 \\ 2005 & 0 \\ 2006 & 0 \\ \text { Contrast } & \end{array}$

Wood Thrush

$$
\text { Contrast }
$$

0.10

A

0
0
0
0
$10(0.10)$

A

$0.08(0.08)$

$0.08(0.08)$

$0.25(0.25)$

$0.20(0.20)$

$\mathrm{F}=1.91 \mathrm{p}=0.181$

B

$1.42(0.33)$
$0.83(0.28)$
$0.83(0.46$
0
$0.40(0.24)$
$=\mathbf{6 . 8 6} \mathbf{p}=\mathbf{0 . 0 1 6}$

A

B

0
0
0
0
$0.08(0.08)$

0

0
0

0

0

0
0

A

$\begin{array}{lll}\text { A } & 9.72 & 0.002\end{array}$

$$
\begin{aligned}
& 1.21(0.36) \\
& 0.79(0.24) \\
& 0.86(0.30) \\
& 0.17(0.17) \\
& 0.42(0.15)
\end{aligned}
$$

$$
F=6.86 p=0.016 \quad F=7.04, p=0.013
$$

Yellow-billed Cuckoo

Contrast $\mathbf{F}=\mathbf{3 . 3 4}, \mathbf{p}=\mathbf{0 . 0 8}$

$\begin{array}{rc}1994 & 0 \\ 1995 & 0.33(0.33) \\ 1996 & 0 \\ 2005 & 0.08(0.08) \\ 2006 & 0.17(0.17) \\ \text { Contrast } & \mathrm{F}=0.01, \mathrm{p}=0.93\end{array}$

Yellow-throated Vireo

$\begin{array}{ll}1994 & 0 \\ 1995 & 0 \\ 1996 & 0 \\ 2005 & 0 \\ 2006 & 0\end{array}$

Late-successional species

Acadian Flycatcher

$\begin{array}{rc}1994 & 0.17(0.17) \\ 1995 & 0.33(0.21) \\ 1996 & 0.67(0.25) \\ 2005 & 0.42(0.20) \\ 2006 & 0.17(0.17) \\ \text { Contrast } & F=0.28, p=0.60\end{array}$

Black-and-white Warbler

$\begin{array}{rc}1994 & 0.42(0.20) \\ 1995 & 0.75(0.17) \\ 1996 & 0.33(0.21) \\ 2005 & 0.58(0.20) \\ 2006 & 0.92(0.08) \\ \text { Contrast } & F=2.33, p=0.14\end{array}$

$1.25(0.42)$
$1.67(0.49)$
$1.00(0.37)$
$0.63(0.47)$
$0.70(0.37)$
$F=2.44 \mathrm{p}=0.133$

$1.07(0.35)$

$0.71(0.31)$

$0.64(0.26)$

$0.33(0.17)$

$0.25(0.17)$

$$
\begin{gathered}
0 \\
0.17(0.17) \\
0 \\
0.25(0.25) \\
0.20(0.20) \\
\mathrm{F}=1.58 \mathrm{p}=0.222
\end{gathered}
$$$$
F=4.18, p=0.05
$$

$0.93 \quad 0.416$

$0.86 \quad 0.442$

$\begin{array}{cc}0 & 0 \\ 0 & 0.14(0.09) \\ 0 & 0 \\ 0 & 0 \\ 0 & 0\end{array}$

$$
\begin{aligned}
& \begin{array}{lll}
0 & 1.57 & 0.238
\end{array} \\
& \begin{array}{cc}
0 & 0.71(0.31) \\
0.33(0.17) & 0.86(0.39) \\
0.25(0.17) & 1.00(0.33) \\
0.25(0.25) & 0.50(0.18) \\
0.20(0.12) & 0.25(0.17)
\end{array} \\
& \mathrm{F}=0.04 \mathrm{p}=0.835 \quad \mathbf{F}=\mathbf{2 . 9 8}, \mathbf{p}=\mathbf{0 . 0 9 5} \\
& \text { A } \\
& 0.42(0.15) \\
& 0.42(0.20) \\
& 0.25(0.17) \\
& 0.38(0.24) \\
& \mathrm{AB} \\
& 0.14(0.09) \\
& 0.21(0.15) \\
& 0 \\
& 0.30(0.20) \\
& 0.42(0.20) \\
& \mathrm{F}=0.02 \mathrm{p}=0.897 \quad \mathrm{~F}=1.36, \mathrm{p}=0.254
\end{aligned}
$$


Appendix 2 continued

Clearcut

Blackburnian Warbler

Black-throated Blue Warbler

\section{4}

1995

1996

2005

2006

Contrast

Black-throated Green Warbler

1994

1995

1996

2005

2006

$$
\text { Cont }
$$

Blue-headed Vireo

\begin{tabular}{cc}
1994 & \multicolumn{1}{c}{0} \\
1995 & 0 \\
1996 & $0.17(0.17)$ \\
2005 & $0.17(0.17)$ \\
2006 & $0.17(0.17)$ \\
Contrast $\mathrm{F}=0.89, \mathrm{p}=0.355$
\end{tabular}

Brown Creeper

$$
\text { Contrast } \mathrm{F}=0.89, \mathrm{p}=0.355
$$

$\begin{array}{ll}1994 & 0 \\ 1995 & 0 \\ 1996 & 0 \\ 2005 & 0 \\ 2006 & 0\end{array}$

Cerulean Warbler

$\begin{array}{cc}1994 & 0 \\ 1995 & 0.17(0.17) \\ 1996 & 0 \\ 2005 & 0.17(0.17) \\ 2006 & 0.17(0.17) \\ \text { Contrast } \mathrm{F}= & 0.89, \mathrm{p}=0.355\end{array}$

Eastern Wood-Pewee

$$
\begin{array}{cc}
1994 & 0.06(0.06) \\
1995 & 0 \\
1996 & 0.25(0.17) \\
2005 & 0 \\
2006 & 0 \\
\text { Contrast } \mathrm{F}=1.93, \mathrm{p}=0.177
\end{array}
$$

Golden-crowned Kinglet
Two-age

Unharvested

$\mathrm{F}(\mathrm{df}=2) \quad p$ trmt

$1.66 \quad 0.221$

$0.14(0.09)$

$0.14(0.14)$

$0.14(0.14)$

$0.50(0.18)$

$\begin{array}{lc}0.20(0.20) & 0.25(0.17) \\ =0.68 p=0.419 & \mathbf{F}=\mathbf{2 . 9 2}, \mathbf{p}=\mathbf{0 . 0 9 9}\end{array}$

B

B

$0.42(0.20) \quad 0.64(0.34)$

$0.17(0.11) \quad 1.07(0.28)$

$0.42(0.27) \quad 1.00(0.31)$

$0.38(0.24)$

$0.50(0.32)$

$0.58(0.15)$

$0.75(0.21)$

$\mathrm{F}=0.22 \mathrm{p}=0.643 \quad \mathrm{~F}=0.86, \mathrm{p}=0.363$

$\begin{array}{lllll}\text { B } & \text { B } & \text { A } & 7.23 & \mathbf{0 . 0 0 6}\end{array}$

$\begin{array}{lllllll}\text { B } & 0.08(0.08) & \text { B } & 1.50(0.44) & \text { A } & \mathbf{6 . 8 2} & \mathbf{0 . 0 0 7}\end{array}$

$\begin{array}{lllllll}\text { B } & 0.33(0.17) & \text { B } & 1.50(0.27) & \text { A } & \mathbf{5 . 7 5} & \mathbf{0 . 0 1 3}\end{array}$

$\begin{array}{llll}0.17(0.17) & 0.57(0.30) & 0.77 & 0.478\end{array}$

$\begin{array}{lllllll}\text { A } & 0.13(0.13) & \text { B } & 1.33(0.25) & \text { A } & \mathbf{7 . 0 9} & \mathbf{0 . 0 0 8}\end{array}$

$\begin{array}{llll}0.80(0.12) & 1.00(0.26) & 0.63 & 0.545\end{array}$

$\mathbf{F}=\mathbf{3 . 9 8} \mathbf{p}=\mathbf{0 . 0 5 9} \quad \mathrm{F}=0.01, \mathrm{p}=0.936$

$\begin{array}{lllll}\text { B } & \text { B } & \text { A } & \mathbf{8 . 7 8} & \mathbf{0 . 0 0 3}\end{array}$

$\begin{array}{lllllll}\text { B } & 0.25(0.11) & \text { AB } & 0.43(0.17) & \text { A } & \mathbf{2 . 9 9} & \mathbf{0 . 0 7 9}\end{array}$

$\begin{array}{lllllll}\text { B } & 0 & \text { B } & 0.64(0.14) & \text { A } & \mathbf{1 7 . 0 5} & <\mathbf{0 . 0 0 1}\end{array}$

$\begin{array}{llll}0.08(0.08) & 0.21(0.15) & 0.23 & 0.799\end{array}$

$0.13(0.13) \quad 0.17(0.11) \quad 0.03 \quad 0.975$

$\begin{array}{lllllll}\text { B } & 0.60(0.19) & \text { B } & 1.33(0.31) & \text { A } & \mathbf{6 . 6 7} & \mathbf{0 . 0 0 9}\end{array}$

$F=5.62 p=0.027 \quad F=3.58, p=0.069$

d

$0.32 \quad 0.729$

$\begin{array}{cc}0.25(0.17) & 0.21(0.21) \\ 0.08(0.08) & 0.29(0.15) \\ 0.08(0.08) & 0.21(0.15) \\ 0 & 0 \\ 0 & 0 \\ =1.96 \mathrm{p}=0.176 & \mathbf{F}=\mathbf{3 . 2 0}, \mathbf{p}=\mathbf{0 . 0 8 4}\end{array}$

$1.51 \quad 0.251$

$$
\begin{array}{cc}
0.25(0.11) & 0.43(0.23) \\
0.42(0.20) & 0.29(0.15) \\
0.42(0.15) & 0.43(0.17) \\
0 & 0 \\
0 & 0.08(0.08) \\
\mathbf{F}=\mathbf{7 . 4 5} \mathbf{p}=\mathbf{0 . 0 1 2} & \mathbf{F}=\mathbf{5 . 3 9}, \mathbf{p}=\mathbf{0 . 0 2 8}
\end{array}
$$

$\begin{array}{cc}0 & 0 \\ 0 & 0 \\ 0 & 0 \\ 0 & 0 \\ 0.20(0.20) & 0\end{array}$


Appendix 2 continued

Clearcut

Hairy Woodpecker

Hermit Thrush

Kentucky Warbler

Least Flycatcher

$\begin{array}{cc}1994 & 0 \\ 1995 & 0 \\ 1996 & 0 \\ 2005 & 0 \\ 2006 & 0.17(0.17) \\ \text { Contrast } \mathrm{F}=1.50, \mathrm{p}=0.232\end{array}$

Two-age

Unharvested

$\mathrm{F}(\mathrm{df}=2) \quad p$ trmt

$\begin{array}{ll}1.68 & 0.217\end{array}$

(20

0
0
0
0
0

$\begin{array}{cc}1994 & 0 \\ 1995 & 0 \\ 1996 & 0 \\ 2005 & 0.08(0.08) \\ 2006 & 0 \\ \text { contrast } & F=1.50, p=0.232\end{array}$

$\begin{array}{rc}1994 & 0 \\ 1995 & 0.17(0.17) \\ 1996 & 0 \\ 2005 & 0 \\ 2006 & 0 \\ \text { Contrast } \mathrm{F}=0.67, \mathrm{p}=0.422\end{array}$

Louisiana Waterthrush

$\begin{array}{cc}1994 & 0 \\ 1995 & 0.17(0.17) \\ 1996 & 0 \\ 2005 & 0 \\ 2006 & 0\end{array}$

Magnolia Warbler

$\begin{array}{rc}1994 & 0.89(0.31) \\ 1995 & 0.83(0.40) \\ 1996 & 0.33(0.33) \\ 2005 & 0.17(0.11) \\ 2006 & 0.25(0.17) \\ \text { Contrast } & \mathbf{F}=\mathbf{3 . 3 4}, \mathbf{p}=\mathbf{0 . 0 8}\end{array}$

Ovenbird

Pileated Woodpecker

$\begin{array}{cl}1994 & 1.06(0.14) \\ 1995 & 1.17(0.31) \\ 1996 & 0.92(0.08) \\ 2005 & 0.50(0.22) \\ 2006 & 0.83(0.21) \\ \text { Contrast } \mathbf{F}=\mathbf{4 . 0 1}, \mathbf{p}=\mathbf{0 . 0 5 6}\end{array}$

$\begin{array}{rc}1994 & 0 \\ 1995 & 0.25(0.17) \\ 1996 & 0 \\ 2005 & 0 \\ 2006 & 0.17(0.17) \\ \text { Contrast } & \mathrm{F}=0.00, \mathrm{p}=1\end{array}$

0
0
$0.17(0.17)$
$0.13(0.13)$
$0.30(0.30)$
$F=1.14 p=0.297$

$0.25(0.17)$
0
0
0
0

$F=1.04 p=0.319$

$F=1.70, p=0.203$

$$
\begin{gathered}
0.36(0.28) \\
0.14(0.14) \\
0 \\
0.17(0.17) \\
0
\end{gathered}
$$

$$
\begin{gathered}
0 \\
0.08(0.08) \\
0.33(0.25) \\
0 \\
0
\end{gathered}
$$

$$
0.50(0.26)
$$$$
0.50(0.34)
$$$$
0
$$$$
0.13(0.13)
$$$$
0.50(0.22)
$$$$
\mathrm{F}=0.01 \mathrm{p}=0.927
$$

$$
\begin{gathered}
0 \\
0 \\
0 \\
0.17(0.17) \\
0
\end{gathered}
$$

$0.29 \quad 0.753$

$1.13 \quad 0.347$
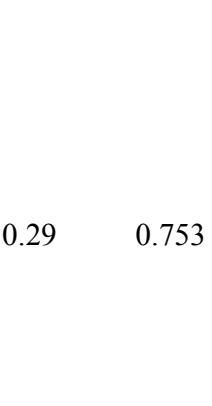
Appendix 2 continued

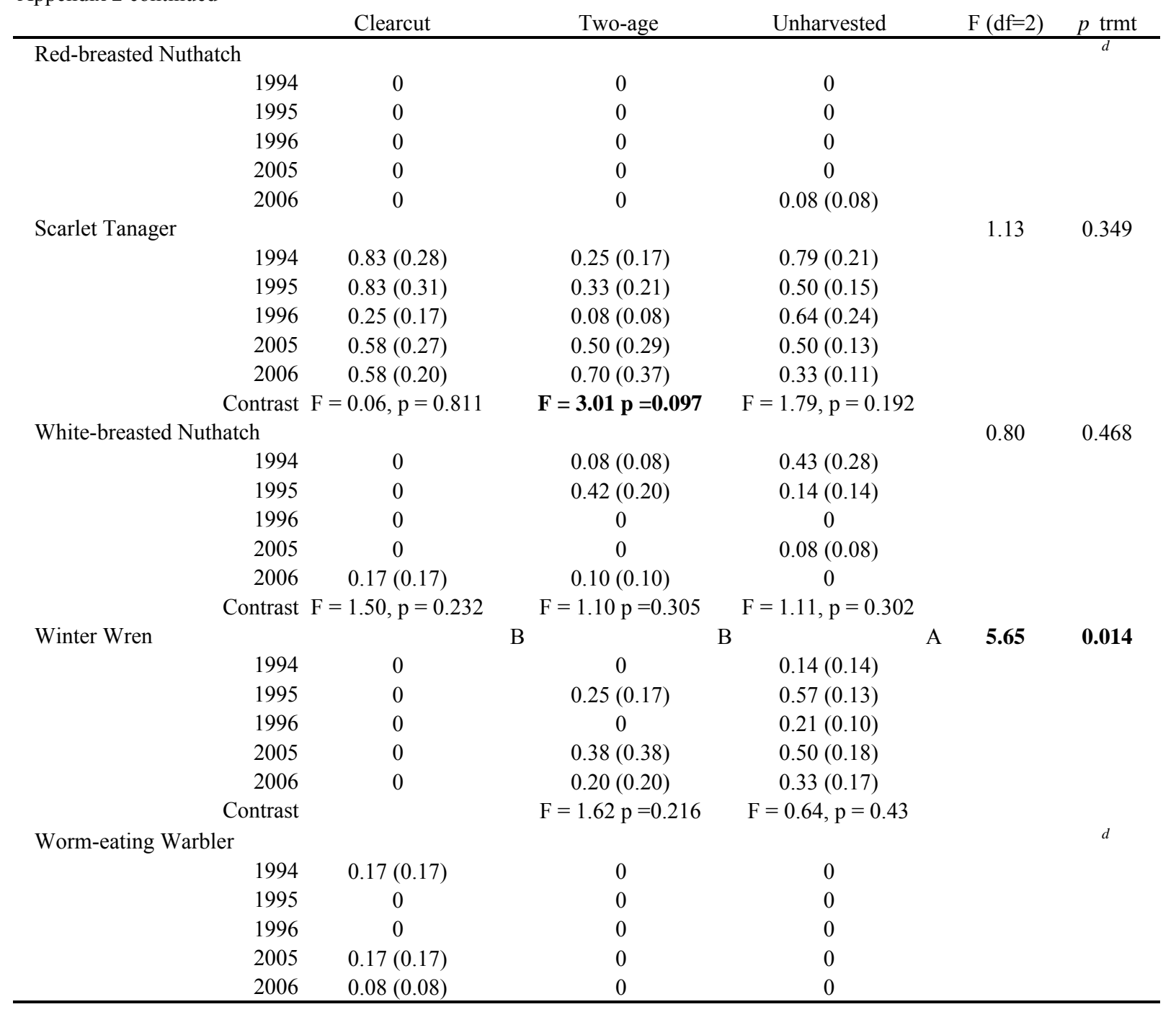

${ }^{a}$ Years are tested separately when there was a significant treatment by year interaction effect.

${ }^{b}$ For a given species or guild means with a different letter differ significantly; Waller-Duncan k-ratio t-tests, $p<0.10$.

${ }^{c}$ Contrasts are between old data collected in 1994-1996 and new data from 2005-2006.

${ }^{d}$ Species too rare for statistical test. 


\section{Chapter 3}

\section{The value of microhabitat cover and food resources in young clearcut and two-age harvests for late- and post- breeding birds.}

Formatted in the style of Journal of Wildlife Management 


\section{Abstract:}

Early-successional habitats are used by a broad assemblage of avian species at the end of the nesting cycle. Several studies have indicated that mature-forest birds switch to different habitats during this time period and rival their early-successional counterparts in the extent of their use of early-successional forest. Although greater cover from predators and increased food resources in young seral forests are suspected factors behind the attraction of birds post-breeding, these hypotheses are rarely addressed when implementing a study. Additionally, effects of residual trees left in harvests have not been quantified for post-breeding birds. I used mist-nets from lateJune to mid-August 2006 to sample post-breeding bird communities in 9 regenerating stands with a gradient of residual basal areas. I measured vegetation characteristics and fruit and arthropod resources at 10 nets within each stand. I analyzed capture data using Poisson regression and information-theoretic approaches to model selection. Vegetative cover and food variables were used to predict bird capture rates by age class, species, habitat guild, species richness, molt index, and an index of physical condition. Cover variables often were among the most important variables in the competing models. Strong positive relations between vertical complexity of the vegetation and capture rates of mature-forest birds and molting adults support the predator-avoidance hypothesis. At the net level, basal area was generally a poor positive predictor of bird captures; although captures in two-age stands were comparable to clearcuts, residual trees within a stand tended to depress capture rates when proximate to nets. Fruit variables appeared to be important for molting birds of both age classes. Arthropod variables best explained capture rates for some groups, but the difficulty of measuring food availability for birds and the lack of data concerning post-breeding food limitation precludes forming conclusions about the resource-selection hypothesis. I also found evidence of age-specific microhabitat use in these stands in terms of food availability, which may in part contribute to the higher body condition index observed for more experienced adult birds. Two-age and clearcut stands provided habitat for many early-successional and mature-forest birds post-breeding with cover appearing to be the primary factor for use by most birds. 
Recent declines in both mature-forest and early-successional bird populations warrant attention to limiting factors and potential mortality sources throughout the year (Robbins et al. 1989, Hunter et al. 2001, Sauer et al. 2005). Although the causes for these declines are not completely understood, habitat loss and fragmentation on breeding and wintering grounds are among the principal suspected factors (Askins et al. 1990). However, little is known about factors affecting survival during other times of the year (i.e., migration and post-breeding) (Pagen et al. 2000).

The post-breeding period, defined as the time interval between the fledging of young and migration, is one of the hardest to study and consequently least known part of the avian life cycle (Baker 1993). Many bird species use early-successional habitat, such as silvicultural clearcuts, extensively during this period. Unpredictably, mature-forest species have been detected in numbers rivaling edge and early-successional species in these habitats (Vitz and Rodewald 2006). Juvenile thrushes make deliberate movements occasionally $>1 \mathrm{~km}$ from their natal area in mature forest into early-successional habitat before migration (Anders et al. 1998, Vega Rivera et al. 1998, White et al. 2005, T. Dellinger, unpublished data). Furthermore, many species of mature-forest breeding songbirds, including worm-eating warbler (Helmitheros vermivorus), Kentucky warbler (Oporornis formosus), hooded warbler (Wilsonia citrina), ovenbird (Seiurus aurocapillus), wood thrush (Hylocichla mustelina), and scarlet tanager (Piranga olivacea), move into early-successional habitat after the young have fledged (Rappole and Ballard 1987, Pagen et al. 2000, Marshall et al. 2003, Vitz and Rodewald 2006). The implications of this shift in habitat use for survival are unclear, but these studies suggest that some birds may benefit from the availability of different habitats during the breeding and postbreeding periods.

Silvicultural treatments that result in high shrub cover during regeneration could be valuable not only for nesting early-successional bird species, but also for species associated with mature forest that use early-successional habitats post-breeding. Two strong hypotheses for this behavior are increased protection from predators (predator-avoidance hypothesis) and greater resource abundance in early-successional forest (resource-selection, or optimal-foraging hypothesis) (White et al. 2005).

The thick understory associated with early-successional habitats provides cover, which is of critical importance to fledglings that lack the knowledge to detect and escape predators and 
thus experience high mortality during the post-fledging period (Sullivan 1989, Anders et al. 1997). Additionally, adults may seek protection and cover during the post-breeding season as they undergo their post-breeding molt, making them temporarily more vulnerable to predators (Pagen et al. 2000). Post-fledging movements into habitat with increased vertical structure were associated with increased survival for young ovenbirds, even where prey abundance was low (King et al. 2006), lending support to the predator-avoidance hypothesis.

Abundant food resources are needed by juveniles for accumulation of fat reserves and completion of molt (DeGraaf and Yamasaki 2003), and by adult passerines that experience a spike in energy demands during their pre-basic molt (Murphy and King 1992). Molt is energetically demanding and requires additional energy and protein not only for synthesizing feathers, but also for increasing metabolism to offset poorer insulation and flight efficiency (Jenni and Winkler 1994). Trees and shrubs fruit earlier in young second growth forest than in mature forest in the summer (Vega Rivera et al. 1998) thus providing increased food resources in shrublands relative to other forest habitats. White et al. (2005) tracked juvenile Swainson's thrushes (Catharus ustulatus) in California during the post-fledging period into habitats not used by breeding adults, including coastal scrub. Swainson's thrush habitat use was best explained by fruit abundance variables, lending support to the resource-selection hypothesis.

Adults of some mature-forest species have been captured in early-successional habitat during the breeding season (Pagen et al. 2000). Most of these birds did not sing and were likely to be floaters or territorial males foraging in these habitats. Thus, some mature-forest bird species are not constrained in their habitat choices by nesting requirements. These breeding period captures suggest that regenerating harvests may be important habitat not only for earlysuccessional breeders, but also for mature-forest breeders as non-nesting habitat.

Despite recent interest in the post-breeding period, no studies have examined how multiple timber harvesting practices impact birds at the end of the nesting cycle. Two-age harvesting is often used in management of Central Appalachian hardwood forests as an alternative to clearcutting (Miller et al. 1995). During a two-age harvest, approximately 25-50 scattered residual canopy trees are left per ha, and all other stems greater than $2.5 \mathrm{~cm}$ in diameter are cut (Smith et al. 1989). A dominant mature age class of residual trees and a regenerating age class result from the harvest, and residual trees remain until the next rotation. The resultant vertical stratification provides habitat for both shrub and canopy-foraging species, and two-age 
harvests have additional conservation benefits for wildlife by retaining mast-producing trees that also serve as nesting and foraging substrates and singing perches (Boardman and Yahner 1999; Duguay et al. 2000).

Several studies have demonstrated the effects of two-age harvesting on breeding birds (Baker and Lacki 1997; Boardman and Yahner 1999; Duguay et al. 2000; Weakland 2000), but no study has looked at bird habitat use of two-age stands post-breeding. Few studies have researched food availability in early-successional habitats during this time period. Only one (Duguay et al. 2000) has examined food resources (arthropod biomass) in two-age harvests. My objectives were to: 1) quantify the response of late- and post-breeding birds to a gradient of residual basal areas and vegetative cover in early-successional habitat and 2) examine how food resource availability may explain patterns in habitat use in these regenerating stands.

\section{Study Area}

The study was conducted at the Monongahela National Forest (MNF) in Pocahontas and Tucker Counties and the MeadWestvaco Wildlife and Ecosystem Research Forest (MWERF) in Randolph County, West Virginia. The forests, both actively managed for timber harvesting, are

located in the Allegheny Mountains region of the Appalachians and are characterized by narrow, low valleys dissected by northeast-southwest ridges. Elevation ranged from 630-1,090 m.

I selected 9 stands for sampling in 2006: 3 clearcuts, which rarely retained any overstory trees, 3 low-leave two-age stands (2.0-3.7 $\mathrm{m}^{2} /$ ha retained basal area), and 3 high-leave two-age stands (5.3-7.0 $\left.\mathrm{m}^{2} / \mathrm{ha}\right)$. After residual basal area, stand age was the most important selection criterion, because of a limited number of harvests on either forest that had similar amounts of regeneration. I chose stands that were between 4 and 7 years post-harvest and, for stands on the MNF, located in closest proximity to the MWERF. Stand size was 4.2-21 ha, and 5 stands were located on the MWERF and 4 on the MNF.

The principal forest types in the study area were northern Allegheny hardwoods, cove hardwoods, mixed mesophytic, and oak-hickory. Dominant overstory tree species in the study stands included red oak (Quercus rubra), red maple (Acer rubrum), chestnut oak (Q. prinus), and yellow poplar (Liriodendron tulipifera). Other residual tree species present were sugar maple (A. saccharum), hickory (Carya spp.), American beech (Fagus grandifolia), black cherry (Prunus serotina), eastern hemlock (Tsuga canadensis), white oak (Q. alba), and cucumber magnolia 
(Magnolia acuminata). The most abundant regenerating understory plants were blackberries (Rubus spp.), black birch (Betula lenta), greenbrier (Smilax spp.), American beech, maples, and yellow poplar.

\section{Methods}

\section{Mist-netting}

I used mist-nets to sample post-breeding bird communities in young harvests, because surveying by vision is difficult under conditions of dense vegetation. As many birds are silent and secretive during the post-breeding period, mist-netting may be one of the most reliable methods for sampling birds in this period (Ralph et al. 2004). Furthermore, as most vegetation in young regenerating stands is near the height of a standard mist-net, mist-netting is an effective choice for sampling birds in this low vertical structure (Pagen et al. 2000). However, there are a few biases associated with this method such as interspecific and intraspecific differences in capture probability due to mean flight and flight frequency differences, differences in net location, variability in net tension, and variability in microclimate differences for each net (Remsen and Good 1996). Mist-net capture rates are a form of relative population estimates, but these should not be compared among species or age classes because of potential differences in capture probabilities (Karr 1981). Here, my goal was not to compare capture rates among groups but rather to relate capture rates to microhabitat food and cover variables.

In 2006 I sampled 9 stands with mist-nets. A mist-net station consisted of 10 nets within each stand, often arranged along 2 or more skid roads established during harvest. Net orientation within stands was usually perpendicular to the prevailing aspect. I arranged nets such that distance from edge was variable, a minimum of $20 \mathrm{~m}$ separated the ends of nets, and each net was within $60 \mathrm{~m}$ of another net. Mist-nets were $12 \mathrm{~m}$ long, $2.6 \mathrm{~m}$ high, and 30-mm mesh, a size most suitable for small passerines (Heimerdinger and Leberman 1966), especially warblers, which comprise most of the locally breeding individuals in the study area (according to preliminary data).

I visited stations randomly for the first round and then repeated a visit in the same order so that visits to the same station were at least 3 weeks apart. A stand $(n=3)$ from each harvest type (clearcut, low-leave two-age and high-leave two-age) was randomly chosen for the first round, and I alternated among these 3. The same order (high-leave, low-leave, clearcut) was 
chosen for each group of 3 stands in each round. Thus, 2 stands of the same harvest type were sampled $\sim 1$ week apart.

I sampled 2 consecutive days at each station and visited each station twice between 25 June and 15 August, a generalized post-breeding period. At each station I opened nets at sunrise and closed after approximately 4 hours (after which time bird activity wanes) except in inclement weather, when stations were not operated. I checked nets every 30 minutes and recorded data from all captured individuals including species, age, sex, wing chord, mass, fat, breeding condition, molt status, and time of capture. Captured birds were fitted with USGS aluminum bands (Pyle 1997) except for ruby-throated hummingbirds (Archilochus colubris). Additionally, I filled out molt cards as per the British Trust for Ornithology (BTO) for actively molting adults to obtain pre-basic molt scores.

\section{Food resource sampling}

In 2006 I sampled fruits twice: once per round in each of the 9 mist-net stands. I obtained an index of fruit abundance by counting individual fruits along $12 \mathrm{~m}$ transects within 1 $\mathrm{m}$ of either side of each mist-net lane (Levey 1988). All fruits were counted, identified to species, and classified as unripe or ripe. All food resource sampling occurred immediately after the first day of mist-netting each round.

I also collected arthropod samples, concurrently with fruit collection, to obtain biomass availability estimates, while recognizing that a bird's perception of food items may be different from ours (Hutto 1990, see Smith and Rotenberry 1990 for review). Although not all arthropods sampled may be part of a bird's diet, I used biomass as an index of food availability, not an absolute measure of food consumed by birds (Hutto 1990, Duguay et al. 2000).

At each net location $(n=90)$ I obtained 4 arthropod samples, 1 from each of 4 shrubs,

each round. I used a beating method whereby saplings within $10 \mathrm{~m}$ of the nets were beaten with a rubber mallet (Schauff 1997). This capture method was suitable for sampling arthropods available to foliage gleaners, the most common foraging guild captured in the pilot year. I chose tree species representative of vegetation composition near the net and understory trees within mist-net height. Samples were taken from 2 random saplings meeting these criteria on each side of the net. Tree species, height, and time of day were recorded while sampling. I often used the 
same individual trees the second round, as the time interval ( $\sim 3$ weeks) allowed for sufficient repopulation time (L. Butler, West Virginia University, personal communication).

I used a sturdy, light-colored sheet $1 \mathrm{~m}^{2}$ in area to capture the arthropods. The sheet was held under the branches of one side of the sapling, and one person beat 4 limbs that were above the sheet from top to bottom (4 beats per limb). Once specimens fell onto the sheet, smaller arthropods were sucked up with an aspirator into a glass vial of ethanol. I picked up larger insects with forceps and placed them into a vial. Specimens were stored in ethanol for later identification in the lab.

I identified all arthropods to order, and classified each individual into 1 of 3 prey size categories: $<3 \mathrm{~mm}, 3-10 \mathrm{~mm}$, and $>10 \mathrm{~mm}$ (Van Horne and Bader 1990). Specimens were subsequently placed on a tray and inserted into a drying oven with a temperature of $60^{\circ} \mathrm{C}$. After 48 hours or when specimens achieved a constant mass, I weighed each sample (by taxonomic order, size, net, and round) to the nearest $0.1 \mathrm{mg}$ to obtain an estimate of biomass. Arthropod richness, at the order level, was calculated as a simple measure of arthropod diversity.

\section{Vegetation sampling}

I measured vegetation on both sides of each 12-m mist-net lane after the second round of mist-netting. Foliage height (canopy cover) was measured on four 12-m transects, $3 \mathrm{~m}$ and $6 \mathrm{~m}$ from the net, that paralleled each side of the net lane (Schemske and Brokaw 1981). I recorded presence or absence of vegetative cover at 5 equidistant intervals along each transect in the following height categories: $0-1 \mathrm{~m},>1-2 \mathrm{~m},>2-3 \mathrm{~m},>3-6 \mathrm{~m},>6-12 \mathrm{~m},>12-18 \mathrm{~m},>18-24 \mathrm{~m}$, and $>24 \mathrm{~m}$. Vertical complexity index (VCI) was calculated as a sum of all canopy cover class percentages divided by 100 and multiplied by a constant (20) (Wood et al. 2005).

I recorded any trees $>7.6 \mathrm{~cm}$ diameter at breast height $(\mathrm{dbh})$ in a $12 \mathrm{~m} \mathrm{x} 12 \mathrm{~m}$ plot centered on the net lane. Additionally, number of small stems $<7.6 \mathrm{~cm}$ dbh and $\%$ ground cover categorized as leaf litter, woody, rock/bare ground, or herbaceous were quantified in two 2 m x 2 $\mathrm{m}$ plots randomly placed on the transect along each side of the net lane. Shrub richness was calculated as the number of species $<7.6 \mathrm{~cm}$ dbh that occurred on each plot. I recorded an upper canopy height where residual trees occurred in the plot and a lower canopy height as a measure of understory vegetation height. I measured basal area with a 10 factor prism from the center of 
the net lane. Elevation was derived from a 30-m digital elevation model (DEM; West Virginia GIS Technical Center) and aspect was recorded with a compass on site.

\section{Data analyses}

I standardized mist-net captures for each species per 100 mist-net hours (Karr 1981). Birds that did not breed locally and were obvious migrants (e.g., Tennessee Warbler and Yellow Warbler) were eliminated from analyses. Individuals recaptured at any time within the season were excluded. I assigned species to 2 habitat guilds: early-successional or mature-forest based on Whitcomb et al. (1981), Ehrlich et al. (1988), and personal observations. Species were placed into foraging guilds (insectivorous or seasonally frugivorous) based on available life history data (e.g., Birds of North America species accounts) and a cursory examination of fecal samples from captured birds.

I performed separate analyses for hatch year (HY) and adult (AHY) birds. Juveniles are usually more susceptible to capture and further, may have different reasons for using particular habitat types compared to adults. I also analyzed post-breeding adults, which were defined as adults with no sign of an active brood patch (if female) or absence of a fully-developed cloacal protuberance (if male) and which had initiated pre-basic molt, indicating termination of breeding (Pyle et al. 1997). I analyzed all adults in addition to post-breeding adults (a subset) because I was interested in modeling habitat use by post-breeding adults separately from late-breeding or non-nesting adults.

To model bird responses to resource availability, I selected explanatory variables that were based on the main hypotheses for resource use. Thus, I chose variables that would represent the value of vegetative cover and food resources to birds (Table 1). For all fruit, arthropod, and vegetation variables, I tested for pairwise correlation among variables using Pearson's product-moment correlation (PROC CORR; SAS Institute 2003). Percentage variables were arcsine transformed to approximate normality. The number of explanatory variables within a category (fruit, arthropod, and vegetative cover) to be incorporated into bird regression models was reduced by this classification method; I dropped strongly correlated variables $(P \geq 0.7)$ to avoid multicollinearity. When choosing between 2 correlated variables, I selected that which was less correlated with other model variables or was most biologically 
meaningful based on the cover and food hypotheses. Nine variables were retained for modeling (Table 1).

I developed sets of a priori candidate models (8-15) for each species or group to explain avian capture rates and other metrics of interest (Appendices 1-5). Models were developed after a careful review of recent literature on post-breeding bird ecology. Arthropod biomass was analysis-specific and prey sizes were chosen based on what is known for specific species or groups of interest. When multiple bird species were combined for a particular analysis, total arthropod biomass included all prey size categories.

The response variables included capture rates of adult and HY birds for species captured at a minimum of $30 \%$ of nets (Table 2) or the top 4 species captured in each habitat guild, and capture rates of each age group classified by diet and habitat preference (all seasonal frugivores, and insectivores by habitat guild). I only analyzed age classes with at least 20 captures. Other response variables were species richness, molt score index for adult and HY birds, and body condition index.

Adult molt score (0-250; Cherry and Cannell 1984) was reclassified to values of 0-6. I did not analyze molt score as continuous, because birds with a score of 0 or 250 essentially are not molting flight feathers; these scores are reclassified as 0 because these birds would be similarly capable of flight. Adults in the heaviest stage of molt with a mid-range pre-basic molt score (100-140) are most likely to have compromised flight and higher energetic demands (Jenni and Winkler 1994); they received the highest reclassified value (6).

Body condition, an index of physical condition calculated by dividing mass (g) by wing length (mm) and multiplying by a constant (Winker 1995), was standardized for each species in order to combine all species for analysis. The individual with the highest body condition index for each species received a score of 1, and each bird's score was a percentage of the top bird. The index was standardized across species in this fashion. The resulting scores were reclassified (0-6) and averaged over all species for each sample.

I used Poisson regression (PROC NLMIXED; SAS Institute 2003) to model each response variable except body condition, which had a normal distribution and was analyzed with linear regression. This procedure (NLMIXED) allows for a hierarchical (i.e., nested) approach to account for within-stand variability, and both Poisson and linear distributions can be modeled. 
Analyses were completed at the net scale because of high variability in food and vegetative resources within a regenerating stand, and the interest in determining microhabitat use patterns.

I used an information theoretic approach to select the best approximating models from each set of candidate models. I employed Akaike's Information Criterion adjusted for small sample sizes $\left(\mathrm{AIC}_{c}\right)$ regardless of the sample size:parameter ratio, because the second-order $\mathrm{AIC}_{c}$ converges to AIC as $n$ becomes large (Burnham and Anderson 2002). Data modeled with a Poisson distribution are often overdispersed (Burnham and Anderson 2002). However, I did not use QAIC to re-rank models, because a random effect was included in the regression models to account for any dispersion problems in the data (SAS Institute 2003). I rescaled the resulting information criteria for each candidate model to obtain $\Delta_{i} \mathrm{AIC}_{c}$ (differences between the top model and every other model) and calculated Akaike weights $\left(w_{i}\right)$ to better interpret the relative likelihood of a model. Models with a $\Delta_{i} \mathrm{AIC}<2$ were given equal consideration as competing models.

\section{Results}

In 2006 we captured 1,189 individuals comprised of 579 HY birds and 610 adults of 15 early-successional and 38 mature-forest species (Table 2). Of all adults, $30 \%$ were considered post-breeding including $25 \%$ of early-successional adults and $35 \%$ of mature-forest adults. Insectivores predominated captures; seasonal frugivores comprised $18 \%$ of species and 19\% of individuals captured. Groups analyzed had total captures of at least 20 individuals and a maximum of 275 for HY and 245 for adult birds (Table 3).

I collected 16 orders of arthropods in the stands sampled, including one subclass: Acari (Appendix 6). In terms of total biomass, Coleoptera, Lepidoptera, Hemiptera, and Homoptera were the primary orders collected, and these 4 comprised most of the individuals in the $3-10 \mathrm{~mm}$ category. Homoptera and Araneae dominated arthropods $<3 \mathrm{~mm}$ in size. Lepidoptera larvae comprised most arthropods $>10 \mathrm{~mm}$ in length.

\section{Modeling bird habitat use}

Early-successional species

For early-successional insectivores, the same cover and food variables were important for both age groups (Table 4). Capture rates were negatively related to vertical complexity (Figure 
1), understory stem density, and basal area. Age groups had opposite relations to food variables. Adults were positively related to arthropod biomass (Figure 2) and negatively to Lepidoptera larvae biomass, the opposite of HY birds.

I analyzed 4 bird species in this guild including 3 that are primarily insectivorous during this time period (Table 3). Chestnut-sided warbler (Dendroica pensylvanica) habitat use was poorly predicted by all variables. For adults, 5 models had a similar likelihood of being selected, while HY capture rates were best explained by the global model. Associations were the same as for all early-successional hatch year captures pooled because this species comprised $67 \%$ of captures in this guild. A negative association with residual basal area best explained common yellowthroat adult (Geothlypis trichas) captures (Figure 3). Indigo bunting (Passerina cyanea)

adult captures were best explained by increases in vertical complexity. Several models competed for explaining HY indigo bunting capture rates. Of these, models with vertical complexity followed by basal area had the highest collective weights (both negative relationships).

Food variables were important for some species. Adult indigo bunting captures were positively associated with herbaceous ground cover, which may represent availability of a particular food source (seeds of herbaceous plants) for this species. Lepidoptera larvae biomass and total arthropod biomass were positive predictors of chestnut-sided warbler HY and adult captures, respectively. HY indigo bunting captures were positively associated with Lepidoptera larvae biomass.

The early-successional breeders were represented by 1 seasonal frugivore: gray catbird (Dumetella carolinensis). Ripe fruit was negatively related to catbird (adult and HY birds) capture rates. Basal area and stem density were positively related to adult gray catbird captures. The global model best explained HY catbird captures. Vertical complexity and basal area were positively related to captures whereas all food variables, except for Lepidoptera larvae biomass, were negatively related.

\section{Mature-forest species}

Adult insectivore capture rates were best explained by both cover and food variables (Table 4). Capture rates increased with increasing vertical complexity (Figure 1), total arthropod biomass (Figure 2) and Lepidoptera larvae biomass and decreased with increasing stem density (Figure 5) and basal area. The global model best predicted capture rates of HY birds. Cover 
variables had the same relationships as with adults, but arthropod biomass was inversely related to captures of HY birds.

I analyzed 5 mature-forest species, including 4 primary insectivores (Table 3). Cover variables dominated the top models for these species (Table 4). Vertical complexity was a top explanatory variable for both HY and adult American redstart captures (Setophaga ruticilla; + relationship). Red-eyed vireo adults (Vireo olivaceus) were also positively associated with vertical complexity. The basal area model received the most support for HY Canada warbler captures (Wilsonia canadensis; $\mathrm{w}=0.28)$ and adult red-eyed vireo captures $(\mathrm{w}=0.23)$ indicating a negative relationship for these species (only 1 age group was tested; Figure 3). The stem density model received a weight of $13 \%$ for red-eyed vireo adult captures and $20 \%$ for hooded warbler adult captures. But these 2 species showed opposite patterns: red-eyed vireo capture rates declined and hooded warbler rates increased with increasing understory stem density.

In general, food variables were positively associated with captures. Lepidoptera larvae with adult hooded warbler and HY American redstart captures; arthropod richness with red-eyed vireo adult captures; arthropod biomass with adult American redstart and hooded warbler captures.

The veery (Catharus fuscescens) was the only seasonal frugivore analyzed in this habitat guild. Adult veery capture rate was positively associated with arthropod biomass (Figure 2) and total fruit. For HY birds, the model with vertical complexity (negative association) was ranked only 1.5 times better than that with ripe fruit (positive association). However these relationships were weak suggesting inadequate model structure.

\section{Frugivores}

Nine species from different breeding habitat associations represented the seasonal frugivores (Table 2). Total fruit abundance was positively associated with both age groups but was not a strong predictor in top models (Table 4). Age groups showed opposite relations with ripe fruit: - for adults and + for HY birds. The model with basal area (positive association) received $33 \%$ of the weight for adults; this variable also had support for HY captures in the global model and was the highest ranked cover parameter when considering all models (Figure 3). 


\section{Post-breeders}

Post-breeding captures of early-successional species were negatively associated with arthropod biomass and vertical complexity, but positively with stem density (Figure 5; Table 4). Models with arthropod biomass, stem density, and these 2 variables + vertical complexity (cover and insect model) all had similarly low weights (0.15-0.20). These post-breeding individuals were mostly chestnut-sided warblers, which also showed no clear microhabitat patterns when all adults were pooled.

For mature-forest post-breeding adults, vertical complexity (positive association) was an important explanatory variable in the top models (combined $58 \%$ of the weight). Captures were weakly related to food variables and negatively to stem density and residual basal area.

\section{Other models}

Species richness at the net level was best explained by stem density ( $w=0.51$; Table 4$)$. In particular, species richness decreased with increasing stem density (Figure 5). Bird species richness also declined with increasing arthropod richness.

Molting HY birds were associated with total fruit abundance, but this was a weak relation (Table 4). This model was about 2.5 times as likely to be selected as the model with arthropod biomass $(\mathrm{w}=0.11)$. Abundance of ripe fruit best explained molt score of adults $(\mathrm{w}=0.69$; Figure 4 ), but the global model also received support. In the global model, all cover variables were positively related to adult molt and vertical complexity was the highest ranked cover variable when considering all models. Complex vertical structure (a high index value) was associated with individuals in the most compromising stage of molt (Figure 6).

Cover variables best explained variation in body condition index (Table 4). Low stem density ( $w=0.17$; Figure 5$)$ and high vertical complexity $(w=0.12$; Figure 6$)$ were the cover variables that best predicted high body condition index values. Arthropod and fruit variables were negatively related to body condition.

\section{Discussion}

\section{Predator-avoidance hypothesis}

Cover variables appear to be important for post-fledging individuals (HY), post-breeding adults, and all adults pooled. These variables often best explained capture rates as well as 
species richness and body condition index. When cover variables were important predictors, most groups or species analyzed were negatively associated with basal area (but not frugivores) and stem density (but not early-successional post-breeding adults, adult catbirds, and hooded warblers). Although bird capture rates were comparable between clearcut and two-age treatments (McDermott chapter 4), within two-age stands they were greater at nets with fewer nearby trees. The negative relationship between basal area and capture rates may be due to some species choosing to use overstory trees (above mist-nets) in a stand compared to understory vegetation if given a choice.

Thicker cover in the form of understory stem density did not seem to positively influence bird captures or species richness. Similarly, Vitz and Rodewald (2007) found a negative relationship between mature-forest bird capture rates and density of low vegetation $<1.5 \mathrm{~m}$ in height. Quite often in my study stands, birds were traveling in foraging flocks that contained several species, and an open understory would facilitate foraging and movement of individuals. Residual trees in two-aged stands inhibit understory growth (and limit the number of small stems; Miller et al. 2006) but also provide more potential cover (hiding places) from aerial predators.

In contrast, early-successional post-breeding adults (mostly chestnut-sided warblers) had higher capture rates in stands with more understory stems. Thus, a higher understory stem density could serve as protective cover for species that breed and tend to remain in earlysuccessional habitat post-breeding. These individuals may be less likely to be mobile and make major habitat shifts prior to migration. Gray catbird adults and hooded warblers, also associated positively with stem density, were likely nesting in the study stands as well.

Vertical complexity was positively related to all mature-forest bird captures, including American redstarts and adult red-eyed vireos. In addition, adults in heavy molt were associated with high vertical complexity. This variable represents the complexity of understory and overstory vegetative structure and was usually greater in stands with residual trees. Less vertical structure in clearcuts may explain why early-successional captures (both adult and HY insectivores), which are typically highest in clearcuts (McDermott chapter 4), were negatively associated with this variable.

Higher capture rates associated with vertical complexity lend support to the predatorevasion hypothesis. Birds may be selecting habitats where probability of survival is higher due 
to protection from predators afforded by increased vegetative complexity. King et al. (2006) discovered that fledgling ovenbirds had higher survival rates where understory vegetative structure was greatest. Predation was the principle cause of mortality for these HY birds. Therefore, vertical complexity may better represent protective cover than understory stem density. Adults in heavy molt have diminished flight capabilities and consequently, are likely to benefit from complex vertical structure that would provide protection from predators.

Body condition index, which is a simple index of the physical condition of a bird, is in theory related to food resources and deposited body fat. A bird that is fat should have a higher mass: wing ratio. However, food resource availability as I measured it did not appear to affect

body condition of a captured bird at the net-level. In fact, both arthropod and fruit variables were negatively related to body condition. Instead, a high index value was associated with high vertical complexity and low stem density.

One theoretical explanation for this pattern is that birds with a higher body condition index may be using the best habitat for protection, which may be the most structurally complex habitat. Birds in worse physical condition may be more likely to take risks or be banished, via inter- or intraspecific competition, to lower quality habitat in terms of survival. Another possibility is that birds with less fat reserves are more likely to use habitat with rich food resources, hence the negative relation between food availability and body condition. A final explanation is that birds that are currently fat have already exploited food resources where they are captured.

\section{Resource-selection hypothesis}

Lepidoptera larvae biomass was a positive predictor of mature-forest HY, adult, and postbreeding adult captures (e.g., Canada warblers and hooded warblers). Also HY earlysuccessional bird captures were positively associated with this variable. Lepidoptera larvae are an important food source for nestling songbirds but also for adults in late spring and summer (Van Horne and Bader 1990, Jones et al. 2003). Clearcuts had a higher biomass of caterpillars in the understory compared to two-age stands in my study, and shrub-dwelling Lepidoptera larvae may be more abundant and have higher biomass in clearcuts compared to mature-forest because of high-foliage volumes of deciduous shrubs (Van Horne and Bader 1990, Keller et al. 2003). 
Thus, some birds, especially mature-forest individuals, may be keying in on this rich energetic source within the study stands.

Total arthropod biomass was an important predictor and positively associated with mature-forest and early-successional insectivore adults (e.g., chestnut-sided warbler), and adult veery captures. The veery, like other seasonal frugivores, also consumes arthropods postbreeding (both fruit and arthropod remains were found in fecal samples). Capture rates for these groups were higher at nets with higher shrub arthropod biomass. Duguay et al. (2000) found that invertebrate biomass was lowest in $\sim 10-15$ year old clearcuts compared to similarly aged twoage stands and unharvested stands sampled from June - mid-July. Daily nest survival rates and daily nestling wood thrush growth were significantly correlated with invertebrate biomass suggesting possible food limitation. However, these stands were older than those we sampled, and arthropod abundance and biomass may be significantly higher in young clearcuts when they become fully stocked (by year 6 or 7) vs. later seral stages (Keller et al. 2003).

The results with species richness contradict the hypothesis that higher arthropod diversity is associated with higher bird species richness or diversity (Abbott 1976); but the relationship between these variables has seldom been tested. Although Abbott (1976) found a significant positive correlation between arthropod diversity at the order level and bird species richness, variables were tested at a coarser scale (4-ha plots) than here. Avian species richness and diversity may be more tied to habitat structure and heterogeneity than diversity of prey items (MacArthur and MacArthur 1961). Moreover, we only measured food availability in one potential foraging zone (understory foliage). Finally, although the arthropod richness model received $25 \%$ of the weight, the relationship was weak.

Of the groups for which arthropod richness was included in analyses, adult indigo bunting and all red-eyed vireo captures were positively associated with this arthropod richness, but they were the third highest ranking models. Arthropod richness (at the order level) did not appear to be a good measure of arthropod diversity. The results from my study may reflect the inability to measure arthropod diversity at a finer scale (i.e., family or species level), or this variable may not be important for explaining bird habitat use during the post-breeding period.

All frugivore HY captures were positively related to ripe fruit, while gray catbird captures were negatively related. Ripe fruits were not abundant in any stands, so catbirds were possibly eating ripe fruits before we sampled them. Alternatively, the response could be an 
artifact of stand-level habitat use. Catbird capture rates were greater in two-age stands.

Clearcuts had more ripe fruit than the two-age stands, but the differences were not statistically significant, and even in August, ripe fruit comprised a relatively small proportion of the total fruit available.

I found few strong relationships with total fruit abundance. White et al. (2005) found a positive relationship between thrush habitat use and fruit abundance, but this association was not found for the veery, the only thrush with an adequate sample size to analyze individually. Adult veeries had only a weak positive relationship. Molting birds of both age groups were positively associated with fruit variables. Changes in food choice have been observed in the field for molting passerines; thus, food availability may influence the timing and place of molt (Jenni and Winkler 1994). Increased energy requirements during molt could be fulfilled by an abundance of fruits (for the $13 \%$ of molting adults and $15 \%$ of molting juveniles that were seasonal frugivores), or alternatively for insectivores, an abundance of arthropods that are attracted to fruits (Sallabanks and Courtney 1992). I did not sample arthropods on Rubus spp. stems because they were structurally dissimilar from, and in general shorter in height than, the sampled saplings, and many stems would not have withstood the beating technique.

I included herbaceous cover as a crude index of seed availability in the models. Of seedeating birds, indigo bunting captures were explained best by herbaceous cover, particularly adults. This variable had weaker support for HY birds (but a negative association). Therefore, herbaceous plants may serve as a cue for seed availability for some granivores.

I found limited evidence for the resource selection hypothesis, which was tested by measuring food availability. Arthropod or fruit abundance often appeared in top models, but the relationship was not always positive. Without behavioral observations to quantify food resource selection, we do not know accurately what constitutes available food to a bird (Hutto 1990). Therefore, despite adjusting for potential prey size differences, foliage-associated arthropod biomass may have misrepresented available food. Further, because of high variability in arthropod communities within a stand, birds may not be able to key in on suitable habitat in terms of food resources at a fine scale.

Another issue is that by sampling birds and arthropods simultaneously, we could be examining the "residue of predation" and not necessarily potential prey (Smith and Rotenberry 1990), which may have resulted in the negative association between body condition and food 
availability variables. Finally, although the resource-selection hypothesis has potential, we do not know how or if food is limiting during the post-breeding period. Food limitation likely varies from year to year and is more likely to occur during breeding because of the food requirements associated with rapidly growing nestlings (Nagy and Holmes 2005).

\section{Age--specific differences}

Age-specific differences were evident for most of the groups analyzed. Because the global model often had most support it is difficult to compare top models. However, looking at the directional importance of each variable, we find substantial differences between age groups. Relationships between bird captures and cover variables were nearly always the same for adults and HY birds; but food variables generally differed between age groups. For instance, HY capture rates were always negatively associated with arthropod biomass, while adult capture rates had a positive relationship. The HY birds could be inexperienced in recognizing arthropod availability cues or could be foraging on arthropods not sampled by my methods. The association between fruit variables and capture rates, although not consistent for either age group, often differed between adult and HY bird captures. These data bolster the argument that adults and HY birds may be keying in on different features, particularly relating to food availability, within a stand. Again, this may represent different age-specific abilities to successfully find food. For most species analyzed, adults had a higher body condition index than juveniles.

\section{Guild--specific differences}

Early-successional species tend to have specific breeding requirements; however, few variables had high power in explaining microhabitat use post-breeding. The chestnut-sided warbler readily breeds in both clearcuts and two-age stands (McDermott chapter 2) but may not be focusing on particular microhabitat features post-breeding, at least none that I measured.

Capture rates of mature-forest species often had explanatory variables, particularly cover variables, that contrasted with those associated with early-successional species capture rates. Early-successional birds were positively associated with stem density, and negatively with vertical complexity, which differed from mature-forest bird captures. As these habitat groups have different breeding habitat requirements, microhabitat requirements during this generalized 
post-breeding period may differ as well. Lepidoptera larvae biomass was positively associated with mature-forest adult capture rates, but negatively with early-successional adult captures. Mature-forest birds foraging in early-successional habitat, either for themselves, their nestlings, or fledglings, may be specifically cuing in on this food resource.

Insectivores and seasonal frugivores differed in their relationships with cover variables. Specifically, basal area was positively associated with frugivore metrics, but insectivore bird capture rates were negatively associated with residual basal area. Because total fruit abundance did not vary among stands, the reasons behind this discrepancy are unclear.

Finally, the results for post-breeding adult captures were relatively similar to those for all adult captures, especially for mature-forest individuals (e.g., Lepidoptera larvae biomass, vertical complexity, basal area). Conversely, early-successional post-breeding adults were associated positively with understory stem density compared to all early-successional adult insectivore captures, which were negatively related to this variable. This may be related to molt-associated requirements of post-breeding adults. Additionally, arthropod biomass was negatively associated with capture rates of post-breeding adults from both habitat guilds, but positively with all adults. Consequently, as the adult category includes late-breeding individuals, arthropod biomass may be more important for nesting vs. post-breeding birds.

\section{Management Implications}

Silvicultural practices create post-breeding habitat used by most locally breeding species in our study area. This study adds to a wealth of data supporting similar conclusions; a mix of seral stages and management types is important for maintaining native species assemblages. Two-age stands, although generally greater in vertical complexity and retaining a higher residual basal area of trees, otherwise have few structural or compositional differences compared to clearcuts. This study suggests that two-age harvests have great potential for providing habitat for both early-successional and mature-forest birds during the breeding and post-breeding periods, and forest managers should aim to increase vertical complexity and implement a mixture of twoage and clearcut practices for even-aged regeneration. Future studies should address food limitation in post-breeding birds and determine what processes shape variability in within-stand microhabitat characteristics. 
This chapter only examined post-breeding bird habitat use in the understory of two-age stands. I also conducted transect surveys to capture bird use of residual trees and birds not targeted by the mesh-size of our mist-nets, and these data are presented elsewhere (McDermott chapter 4). Also, only one year of data was able to be used for analyses. The results of this study may not apply to other regions, especially with different landscape configurations.

Survival may be compromised by ignoring bird habitat requirements outside of the breeding season (King et al. 2006). Despite data showing concentrations of birds in earlysuccessional habitat after breeding, habitat use does not necessarily imply habitat quality. Researchers need to gather survival data in early-successional habitats to determine the true value of these habitats. The potential of higher survival in young clearcut and two-age stands compared to other habitats is a critical question that should be investigated further.

\section{Literature Cited}

Abbott, I. 1976. Comparisons of habitat structure and plant, arthropod and bird diversity between mainland and island sites near Perth, western Australia. Australian Journal of Ecology 1: 275-280.

Anders, A. D., D. C. Dearborn, J. Faaborg, and F. R. Thompson, III. 1997. Juvenile survival in a population of Neotropical migrant birds. Conservation Biology 11: 698-707.

Anders, A. D., J. Faaborg, and F. R. Thompson, III. 1998. Postfledging dispersal, habitat use, and home-range size of juvenile Wood Thrushes. Auk 115: 349-358.

Askins, R. A., J. F. Lynch, and R. Greenberg. 1990. Population declines in migratory birds of eastern North America. Current Ornithology 7: 1-57.

Baker, R. R. 1993. The function of post-fledging exploration: a pilot study of three species of passerines ringed in Britain. Ornis Scandinavica 24: 71-79.

Baker, M. D., and M. J. Lacki. 1997. Short-term changes in bird communities in response to silvicultural prescriptions. Forest Ecology and Management 96: 27-36.

Boardman, L. A., and R. H. Yahner. 1999. Wildlife communities associated with even-aged reproduction stands in two state forests of Pennsylvania. Northern Journal of Applied Forestry 16: 89-95.

Burnham, K. P., and D. R. Anderson. 2002. Model selection and multimodel inference: A practical-theoretic approach. Second edition. Springer-Verlag, New York, New York, USA. 
Cherry, J. D., and P. F. Cannell. 1984. Rate and timing of prebasic molt of adult Boreal Chickadees. Journal of Field Ornithology 55: 487-489.

DeGraaf, R. M., and M. Yamasaki. 2003. Options for managing early-successional forest and shrubland bird habitats in the northeastern United States. Forest Ecology and Management 185: 179-191.

Duguay, J. P., P. B. Wood, and G. W. Miller. 2000. Effects of timber harvests on invertebrates biomass and avian nest success. Wildlife Society Bulletin 28: 1123-1131.

Ehrlich, P. R., D. S. Dobkin, and D. Wheye. 1988. The birder's handbook. Simon and Schuster, New York, New York, USA.

Heimerdinger, M. A., and R. C. Leberman. 1966. The comparative efficiency of 30 and $36 \mathrm{~mm}$ mesh mist nets. Bird-Banding 37: 280-285.

Hunter, W. C., D. A. Buehler, R. A. Canterbury, J. L. Confer, and P. B. Hamel. 2001. Conservation of disturbance-dependent birds in eastern North America. Wildlife Society Bulletin 29: 440-455.

Hutto R. L. 1990. Measuring the availability of food resources. Studies in Avian Biology 13: 20-28.

Jenni, L., and R. Winkler. 1994. Moult and ageing of European passerines. Academic Press Limited, London, England.

Jones, J., P. J. Doran, and R. T. Holmes. 2003. Climate and food synchronize regional forest bird abundances. Ecology 84: 3024-3032.

Karr, J. R. 1981. Surveying birds with mist nets. Studies in Avian Biology 6: 62-67.

Keller, J. K., M. E. Richmond, and C. R. Smith. 2003. An explanation of patterns of breeding bird species richness and density following clearcutting in northeastern USA forests. Forest Ecology and Management 174: 541-564.

King, D. I, R. M. Degraaf, M. L. Smith, and J. P. Buonaccorsi. 2006. Habitat selection and habitat-specific survival of fledgling ovenbirds (Seiurus aurocapilla). Journal of Zoology 269: 414-421.

Levey, D. 1988. Spatial and temporal variation in Costa Rican fruit and fruit-eating bird abundance. Ecological Monographs 58: 251-269.

MacArthur, R. H., and J. W. MacArthur. 1961. On bird species diversity. Ecology 42: 594-598. 
Marshall, M. R., J. A. DeCecco, A. B. Williams, G. A. Gale, and R. J. Cooper. 2003. Use of regenerating clearcuts by late-successional bird species and their young during the postfledging period. Forest Ecology and Management 183: 127-135.

Miller, G. W., P. B. Wood, and J. V. Nichols. 1995. Two-age silviculture: an innovative tool for enhancing species diversity and vertical structure in Appalachian hardwoods. Pages 175182 in L. G. Eskew, compiler. Forest health through silviculture. Proceedings of the 1995 national silviculture workshop. General technical report RM-GTR-267. U.S. Forest Service, Rocky Mountain Forest and Range Experiment Station, Fort Collins, Colorado, USA.

Miller, G. W., J. N. Kochenderfer, and D. B. Fekedulegn. 2006. Influence of individual reserve trees on nearby reproduction in two-aged Appalachian hardwood stands. Forest Ecology and Management 224: 241-251.

Murphy, M. E., and J. R. King. 1992. Energy and nutrient use during moult by white-crowned sparrows, Zonotrichia leucophrys gambelii. Ornis Scandinavica 23: 304-313.

Nagy, L. R., and R. T. Holmes. 2005. Food limits annual fecundity of a migratory songbird: an experimental study. Ecology 86: 675-681.

Pagen, R. W., F. R. Thompson, III, and D. E. Burhans. 2000. Breeding and post-breeding habitat use by forest migrant songbirds in the Missouri Ozarks. Condor 102: 738-747.

Pyle, P. 1997. Identification guide to North American birds. Slate Creek Press, Bolinas, California, USA.

Ralph, C. J., E. H. Dunn, W. J. Peach, and C. M. Handel. 2004. Recommendations for the use of mist nets for inventory and monitoring of bird populations. Studies in Avian Biology 29:187-196.

Rappole, J. H., and K. Ballard. 1987. Postbreeding movements of selected species of birds in Athens, Georgia. Wilson Bulletin 99: 475-480.

Remsen, J. V., Jr., and D. A. Good. 1996. Misuse of data from mist-net captures to assess relative abundance in bird populations. Auk 113: 381-398.

Robbins, C. S., J. R. Sauer, R. S. Greenberg, and S. Droege. 1989. Population declines in North American birds that migrate to the Neotropics. Proceedings of the National Academy of Science, USA 86: 7658-7662.

Sallabanks, R., and S. P. Courtney. 1992. Frugivory, seed predation, and insect-vertebrate interactions. Annual Review of Entomology 37: 377-400.

SAS Institute. 2003. Version 9.1. SAS Institute, Cary, North Carolina, USA. 
Sauer, J. R., J. E. Hines, and J. Fallon. 2005. The North American Breeding Bird Survey, Results and Analysis 1966 - 2005. Version 6.2.2006. USGS Patuxent Wildlife Research Center, Laurel, Maryland, USA.

Schauff, M. E. 1997. Collecting and preserving insects and mites: techniques and tools. NHB168. Systematic Entomology Laboratory, USDA, National Museum of Natural History. Washington, D.C., USA.

Schemske, D. W., and N. Brokaw. 1981. Treefalls and the distribution of understory birds in a tropical forest. Ecology 62: 938-945.

Smith, H. C., N. I. Lamson, and G. W. Miller. 1989. An esthetic alternative to clearcutting? Journal of Forestry 87: 14-18.

Smith, K. G., and J. T. Rotenberry. 1990. Quantifying food resources in avian studies: present problems and future needs. Studies in Avian Biology 13: 3-5.

Sullivan, K. A. 1989. Predation and Starvation: Age-specific mortality in juvenile juncos (Junco phaenotus). Journal of Animal Ecology 58: 275-286.

Van Horne, B., and A. Bader. 1990. Diet of nestling winter wrens in relationship to food availability. Condor 92: 413-420.

Vega Rivera, J. H., J. H. Rappole, W. J. McShea, and C. A. Haas. 1998. Wood Thrush postfledging movements and habitat use in northern Virginia. Condor 100: 69-78.

Vitz, A. C., and A. D. Rodewald. 2006. Can regenerating clearcuts benefit mature-forest songbirds? An examination of post-breeding ecology. Biological Conservation 127: $477-486$.

Vitz, A. C., and A. D. Rodewald. 2007. Vegetative and fruit resources as determinants of habitat use by mature-forest birds during the postbreeding period. Auk 124: 494-507.

Weakland, C. A. 2000. Songbird response to diameter-limit and two-aged timber harvesting on an industrial forest in central West Virginia. Dissertation, West Virginia University, Morgantown, West Virginia, USA.

White, J. D., T. Gardali, F. R. Thompson, III, and J. Faaborg. 2005. Resource selection by juvenile Swainson's Thrushes during the postfledging period. Condor 107: 388-401.

Whitcomb, R. F., C. S. Robbins, J. F. Lynch, B. L. Klimkiewicz, and D. Bystrak. 1981. Effects of forest fragmentation on avifauna of the eastern deciduous forest. Pages 125-206 in R.L. Burgess, and D. M. Sharpe, editors. Forest island dynamics in man-dominated landscapes. Springer-Verlag, New York, New York, USA. 
Winker, K. 1995. Autumn stopover on the Isthmus of Tehuantepec by woodland NearcticNeotropic migrants. Auk 112: 690-700.

Wood, P. B., J. P. Duguay, and J. V. Nichols. 2005. Cerulean warbler use of regenerated clearcuts and two-age harvests. Wildlife Society Bulletin 33: 851-858. 
Table 1. Net-level vegetative and food resource variables used to model bird use of early-successional habitats during the post-breeding period in north-central West Virginia, 2006. Resources were sampled from late-June through mid-August.

\begin{tabular}{|c|c|c|c|c|}
\hline Variable & Code & Value range & Mean & SE \\
\hline \multicolumn{5}{|l|}{ Vegetative cover } \\
\hline Understory stem density $^{\mathrm{a}}$ & DENSE & $34-282$ & 121.42 & 3.74 \\
\hline Residual basal area $\mathrm{m}^{2} / \mathrm{ha}$ & BA & $0-11.48$ & 3.02 & 0.24 \\
\hline Vertical complexity index ${ }^{b}$ & VCI & $42-117$ & 74.92 & 0.98 \\
\hline \multicolumn{5}{|l|}{ Fruit resources ${ }^{c}$} \\
\hline Fruit abundance & FRUIT & $95-4,408$ & 802.07 & 41.57 \\
\hline Total ripe fruit & RIPE & $0-846$ & 18.65 & 5.29 \\
\hline \multicolumn{5}{|l|}{ Arthropod resources ${ }^{\mathrm{d}}$} \\
\hline Arthropod richness (number of orders) & $\mathrm{RICH}$ & $5-12$ & 8.33 & 0.11 \\
\hline Total arthropod biomass (mg) & ARTH & $15.3-407.9$ & 100.04 & 5.46 \\
\hline Lepidoptera larvae biomass (mg) & LEP & $0-373.3$ & 16.19 & 2.25 \\
\hline \multicolumn{5}{|l|}{ Seed resources } \\
\hline$\%$ Herbaceous ground cover & SEED & $3-100$ & 47.6 & 1.97 \\
\hline
\end{tabular}

${ }^{a}$ Number of stems $<7.6 \mathrm{~cm}$ dbh counted at two $2 \times 2 \mathrm{~m}$ plots on either side of each mist-net lane.

${ }^{\mathrm{b}}$ Vertical complexity index was calculated as a sum of all canopy cover class percentages divided by 100 and multiplied by 20 .

${ }^{\mathrm{c}}$ Fruit was measured along two $12 \mathrm{x} 1 \mathrm{~m}$ transects on either side of each mist-net lane.

${ }^{\mathrm{d}}$ Arthropods were sampled with a beating technique at 4 shrubs per net. 
Table 2. Species of hatch year birds (HY), adults (AHY), and post-breeding (PB) adults classified by habitat and foraging guilds captured by mist-nets in 2006 in north-central West Virginia. Post-breeding adults were individuals that showed no sign of breeding and had begun pre-basic molt.

\begin{tabular}{|c|c|c|c|c|c|c|c|c|c|}
\hline Species & Scientific name & $\begin{array}{l}\text { Seasonal } \\
\text { foraging }^{\mathrm{a}}\end{array}$ & $\begin{array}{c}\text { Breeding } \\
\text { status }^{\mathrm{b}}\end{array}$ & $\begin{array}{c}\text { HY } \\
\text { captures }\end{array}$ & $\begin{array}{c}\text { AHY } \\
\text { captures }\end{array}$ & $\begin{array}{c}\text { Total } \\
\text { captures }\end{array}$ & $\begin{array}{c}\mathrm{PB} \\
\text { adults }\end{array}$ & $\begin{array}{c}\% \text { of } \\
\text { adults PB }\end{array}$ & $\begin{array}{l}\% \text { of } \\
\text { nets }\end{array}$ \\
\hline \multicolumn{10}{|l|}{ Early-successional species } \\
\hline Chestnut-sided warbler & Dendroica pensylvanica & I & $\mathrm{B}$ & 186 & 123 & 309 & 60 & 49 & 87 \\
\hline Gray catbird & Dumetella carolinensis & $\mathrm{F}$ & $\mathrm{B}$ & 36 & 39 & 75 & 3 & 8 & 36 \\
\hline Indigo bunting & Passerina cyanea & I & $\mathrm{B}$ & 22 & 41 & 63 & 1 & 2 & 44 \\
\hline Common yellowthroat & Geothlypis trichas & I & $\mathrm{B}$ & 16 & 26 & 42 & 1 & 4 & 27 \\
\hline Field sparrow & Spizella pusilla & I & $\mathrm{B}$ & 9 & 13 & 22 & 1 & 8 & 14 \\
\hline Mourning warbler & Oporornis philadelphia & I & $\mathrm{B}$ & 10 & 7 & 17 & 5 & 71 & 13 \\
\hline Eastern phoebe & Sayornis phoebe & I & $\mathrm{B}$ & 5 & 3 & 8 & 0 & 0 & 4 \\
\hline American goldfinch & Carduelis tristis & I & $\mathrm{B}$ & 0 & 6 & 6 & 0 & 0 & 4 \\
\hline Carolina wren & Thryothorus ludovicianus & I & B & 1 & 3 & 4 & 0 & 0 & 2 \\
\hline Blue-winged warbler & Vermivora pinus & I & $\mathrm{B}$ & 1 & 3 & 4 & 2 & 67 & 4 \\
\hline \multicolumn{10}{|l|}{ Mature-forest species } \\
\hline Veery & Catharus fuscescens & $\mathrm{F}$ & $\mathrm{B}$ & 29 & 39 & 68 & 7 & 18 & 43 \\
\hline Red-eyed vireo & Vireo olivaceus & I & B & 8 & 51 & 59 & 18 & 35 & 37 \\
\hline American redstart & Setophaga ruticilla & I & $\mathrm{B}$ & 32 & 26 & 58 & 20 & 77 & 32 \\
\hline Hooded warbler & Wilsonia citrina & I & B & 15 & 34 & 49 & 9 & 26 & 33 \\
\hline Ruby-throated hummingbird & Archilochus colubris & I & $\mathrm{B}$ & 27 & 21 & 48 & . & . & 21 \\
\hline Canada warbler & Wilsonia canadensis & I & $\mathrm{B}$ & 23 & 18 & 41 & 15 & 83 & 30 \\
\hline Black-and-white warbler & Mniotilta varia & I & $\mathrm{B}$ & 25 & 12 & 37 & 7 & 58 & 27 \\
\hline Cedar waxwing & Bombycilla cedrorum & $\mathrm{F}$ & $\mathrm{B}$ & 1 & 25 & 26 & 0 & 0 & 16 \\
\hline Dark-eyed junco & Junco hyemalis & I & $\mathrm{B}$ & 19 & 6 & 25 & 0 & 0 & 16 \\
\hline
\end{tabular}




\begin{tabular}{|c|c|c|c|c|c|c|c|c|c|}
\hline Species & Scientific name & $\begin{array}{l}\text { Seasonal } \\
\text { foraging }^{\mathrm{a}}\end{array}$ & $\begin{array}{c}\text { Breeding } \\
\text { status }^{\mathrm{b}}\end{array}$ & $\begin{array}{c}\text { HY } \\
\text { captures }\end{array}$ & $\begin{array}{c}\text { AHY } \\
\text { captures }\end{array}$ & $\begin{array}{c}\text { Total } \\
\text { captures }\end{array}$ & $\begin{array}{c}\text { PB } \\
\text { adults } \\
\end{array}$ & $\begin{array}{c}\% \text { of } \\
\text { adults PB }\end{array}$ & $\begin{array}{l}\% \text { of } \\
\text { nets }\end{array}$ \\
\hline \multicolumn{10}{|l|}{ Mature-forest species } \\
\hline Scarlet tanager & Piranga olivacea & $\mathrm{F}$ & $\mathrm{B}$ & 1 & 6 & 7 & 3 & 50 & 6 \\
\hline Winter wren & Troglodytes troglodytes & I & $\mathrm{B}$ & 5 & 2 & 7 & 0 & 0 & 7 \\
\hline Wood thrush & Hylocichla mustelina & $\mathrm{F}$ & $\mathrm{B}$ & 3 & 3 & 6 & 1 & 33 & 6 \\
\hline Downy woodpecker & Picoides pubescens & I & $\mathrm{B}$ & 6 & 0 & 6 & 0 & . & 6 \\
\hline Blackburnian warbler & Dendroica fusca & I & $\mathrm{B}$ & 6 & 0 & 6 & 0 & . & 4 \\
\hline Hermit thrush & Catharus guttatus & $\mathrm{F}$ & $\mathrm{B}$ & 5 & 1 & 6 & 0 & 0 & 7 \\
\hline Least flycatcher & Empidonax minimus & I & $\mathrm{B}$ & 4 & 1 & 5 & 0 & 0 & 6 \\
\hline Kentucky warbler & Oporornis formosus & I & $\mathrm{B}$ & 1 & 3 & 4 & 0 & 0 & 2 \\
\hline Northern flicker & Colaptes auratus & I & B & 2 & 1 & 3 & 0 & 0 & 2 \\
\hline Acadian flycatcher & Empidonax virescens & I & B & 2 & 0 & 2 & 0 & . & 2 \\
\hline Brown creeper & Certhia americana & I & $\mathrm{B}$ & 2 & 0 & 2 & 0 & . & 2 \\
\hline Tennessee warbler & Vermivora peregrina & . & NB & 0 & 2 & 2 & . & . & 0 \\
\hline Yellow warbler & Dendroica petechia & . & NB & 2 & 0 & 2 & . & . & 1 \\
\hline American robin & Turdus migratorius & $\mathrm{F}$ & B & 0 & 1 & 1 & 0 & 0 & 0 \\
\hline Hairy woodpecker & Picoides villosus & I & $\mathrm{B}$ & 0 & 1 & 1 & 1 & 100 & 1 \\
\hline Baltimore oriole & Icterus galbula & I & $\mathrm{B}$ & 1 & 0 & 1 & 0 & . & 1 \\
\hline Cerulean warbler & Dendroica cerulea & I & $\mathrm{B}$ & 0 & 1 & 1 & 0 & 0 & 1 \\
\hline Black-billed cuckoo & Coсcyzus erythropthalmus & I & $\mathrm{B}$ & 0 & 1 & 1 & 0 & 0 & 1 \\
\hline Blue-gray gnatcatcher & Polioptila caerulea & I & B & 1 & 0 & 1 & 0 & . & 1 \\
\hline Yellow-throated vireo & Vireo flavifrons & I & $\mathrm{B}$ & 1 & 0 & 1 & 0 & . & 1 \\
\hline White-breasted nuthatch & Sitta carolinensis & I & $\mathrm{B}$ & 1 & 0 & 1 & 0 & . & 1 \\
\hline Sharp-shinned hawk & Accipiter striatus & . & $\mathrm{B}$ & 0 & 1 & 1 & . & . & 1 \\
\hline Totals & & & & 579 & 610 & 1189 & 183 & & \\
\hline
\end{tabular}

${ }^{\mathrm{a}}$ Foraging guilds analyzed were $\mathrm{I}=$ insectivores (primarily during post-breeding period) and $\mathrm{F}=$ frugivores (seasonal).

${ }^{\mathrm{b}}$ Breeding status was $\mathrm{B}=$ locally breeding-species or $\mathrm{NB}=$ not locally breeding.

${ }^{\mathrm{c}}$ Willow (E. traillii ) or alder flycatcher (E. alnorum). 
Table 3. Number of individuals captured for groups analyzed (in bold) in regression models. Birds were captured by mist-nets in North-central West Virginia, July-August 2006.

\begin{tabular}{|c|c|c|c|c|c|}
\hline Species & $\begin{array}{l}\text { Seasonal } \\
\text { foraging }^{\mathrm{a}}\end{array}$ & $\begin{array}{c}\text { Total } \\
\text { captures }\end{array}$ & HY & $\begin{array}{c}\text { Captures }^{\mathrm{b}} \\
\text { AHY }\end{array}$ & PB \\
\hline \multicolumn{6}{|l|}{ Early-successional species } \\
\hline Gray catbird & $\mathrm{F}$ & 75 & 36 & 39 & . \\
\hline Chestnut-sided warbler & I & 309 & 186 & 123 & . \\
\hline Indigo bunting & I & 63 & 22 & 41 & . \\
\hline Common yellowthroat & I & 42 & 16 & 26 & . \\
\hline Early-successional insectivores & I & 520 & 275 & 245 & . \\
\hline Early-successional birds & $\mathrm{I} / \mathrm{F}$ & $\cdot$ & $\cdot$ & . & 74 \\
\hline \multicolumn{6}{|l|}{ Mature-forest species } \\
\hline Veery & $\mathrm{F}$ & 68 & 29 & 39 & . \\
\hline Red-eyed vireo & I & 59 & 8 & 51 & . \\
\hline American redstart & I & 58 & 32 & 26 & . \\
\hline Hooded warbler & I & 49 & 15 & 34 & . \\
\hline Canada warbler & I & 41 & 23 & 18 & . \\
\hline Mature-forest insectivores & $\mathrm{I}$ & 440 & 213 & 227 & . \\
\hline Mature-forest birds & $\mathrm{I} / \mathrm{F}$ & . & $\cdot$ & $\cdot$ & 109 \\
\hline Frugivores & $\mathrm{F}$ & 225 & 89 & 136 & . \\
\hline
\end{tabular}

${ }^{\text {a }}$ Foraging guilds analyzed were $\mathrm{I}=$ insectivores (primarily during post-breeding period) and $\mathrm{F}=$ frugivores (seasonal).

${ }^{\mathrm{b}} \mathrm{HY}=$ hatch year birds, $\mathrm{AHY}=$ after hatching year (adults), and $\mathrm{PB}=$ post-breeding adults. 
Table 4. Poisson regression analysis on bird capture rates by species, guild, and age group in north-central West Virginia, 2006. Models were selected using Akaike's Information Criteria $\left(\mathrm{AIC}_{c}\right)$. Models with $\Delta_{i} \quad \mathrm{AIC}_{c}<2$ and weight $\geq 10 \%$ are presented.

\begin{tabular}{|c|c|c|c|c|c|c|c|c|c|c|c|c|c|}
\hline Response variable & $\mathrm{K}$ & $\mathrm{AIC}_{c}$ & $\Delta_{i} \mathrm{AIC}_{c}$ & $w_{i}$ & $\mathrm{VCI}^{\mathrm{a}}$ & DENSE & BA & $\mathrm{RICH}$ & ARTH & LEP & FRUIT & RIPE & SEED \\
\hline \multicolumn{14}{|l|}{ Early-successional insectivores } \\
\hline \multirow[t]{3}{*}{ All adults } & 7 & 695.55 & 0.00 & 0.28 & - & - & - & & + & - & & & \\
\hline & 3 & 695.64 & 0.09 & 0.27 & & & & & + & & & & \\
\hline & 3 & 696.04 & 0.49 & 0.22 & & & & & & - & & & \\
\hline All HY & 7 & 865.55 & 0.00 & 0.61 & - & - & - & & - & + & & & \\
\hline \multirow[t]{5}{*}{ Chestnut-sided warbler adults } & 3 & 503.04 & 0.00 & 0.28 & & & & & & - & & & \\
\hline & 3 & 503.74 & 0.70 & 0.20 & & & & & + & & & & \\
\hline & 3 & 504.14 & 1.10 & 0.16 & & & + & & & & & & \\
\hline & 3 & 504.34 & 1.30 & 0.15 & & + & & & & & & & \\
\hline & 3 & 504.44 & 1.40 & 0.14 & - & & & & & & & & \\
\hline Chestnut-sided warbler HY & 7 & 713.45 & 0.00 & 0.39 & - & - & - & & - & + & & & \\
\hline Common yellowthroat adults & 3 & 184.34 & 0.00 & 0.86 & & & - & & & & & & \\
\hline \multirow[t]{4}{*}{ Indigo bunting adults } & 3 & 247.14 & 0.00 & 0.18 & + & & & & & & & & \\
\hline & 3 & 247.24 & 0.10 & 0.17 & & & & & & & & & + \\
\hline & 3 & 247.64 & 0.50 & 0.14 & & & & + & & & & & \\
\hline & 4 & 248.43 & 1.29 & 0.10 & & & & & & & & & + \\
\hline \multicolumn{14}{|l|}{ Early-successional frugivores } \\
\hline \multirow[t]{4}{*}{ Gray catbird adults } & 3 & 235.74 & 0.00 & 0.23 & & & + & & & & & & \\
\hline & 3 & 236.64 & 0.90 & 0.15 & - & & & & & & & & \\
\hline & 3 & 236.94 & 1.20 & 0.13 & & & & & & & & - & \\
\hline & 5 & 236.94 & 1.21 & 0.13 & - & + & + & & & & & & \\
\hline Gray catbird HY & 9 & 211.66 & 0.00 & 0.47 & + & - & + & & - & + & - & - & \\
\hline \multicolumn{14}{|l|}{ Mature-forest insectivores } \\
\hline \multirow[t]{2}{*}{ Adults } & 5 & 673.34 & 0.00 & 0.48 & + & - & & & + & & & & \\
\hline & 7 & 674.35 & 1.01 & 0.29 & + & - & - & & + & + & & & \\
\hline HY & 7 & 698.05 & 0.00 & 0.94 & + & - & - & & - & + & & & \\
\hline \multirow[t]{4}{*}{ American redstart adults } & 3 & 166.64 & 0.00 & 0.26 & & - & & & & & & & \\
\hline & 5 & 166.74 & 0.11 & 0.25 & + & - & & & + & & & & \\
\hline & 3 & 167.64 & 1.00 & 0.16 & & & & & + & & & & \\
\hline & 3 & 168.54 & 1.90 & 0.10 & + & & & & & & & & \\
\hline \multirow[t]{3}{*}{ American redstart HY } & 5 & 206.94 & 0.00 & 0.28 & + & + & & & - & & & & \\
\hline & 3 & 207.04 & 0.09 & 0.26 & + & & & & & & & & \\
\hline & 7 & 208.05 & 1.11 & 0.16 & + & + & + & & - & + & & & \\
\hline \multirow[t]{4}{*}{ Canada warbler HY } & 3 & 184.84 & 0.00 & 0.28 & & & - & & & & & & \\
\hline & 3 & 185.24 & 0.40 & 0.23 & & & & & - & & & & \\
\hline & 3 & 186.54 & 1.70 & 0.12 & & - & & & & & & & \\
\hline & 3 & 186.64 & 1.80 & 0.11 & - & & & & & & & & \\
\hline \multirow[t]{3}{*}{ Hooded warbler adults } & 3 & 224.34 & 0.00 & 0.21 & & & & & + & & & & \\
\hline & 3 & 224.44 & 0.10 & 0.20 & & + & & & & & & & \\
\hline & 3 & 224.94 & 0.60 & 0.16 & & & & & & + & & & \\
\hline \multirow[t]{4}{*}{ Red-eyed vireo adults } & 3 & 313.34 & 0.00 & 0.23 & & & - & & & & & & \\
\hline & 3 & 314.34 & 1.00 & 0.14 & & & & + & & & & & \\
\hline & 3 & 314.44 & 1.10 & 0.13 & & - & & & & & & & \\
\hline & 5 & 314.94 & 1.61 & 0.10 & + & - & - & & & & & & \\
\hline
\end{tabular}


Table 4 continued

\begin{tabular}{|c|c|c|c|c|c|c|c|c|c|c|c|c|c|}
\hline Response variable & $\mathrm{K}$ & $\mathrm{AIC}_{c}$ & $\Delta_{i} \mathrm{AIC}_{c}$ & $w_{i}$ & $\mathrm{VCI}$ & DENSE & $\mathrm{BA}$ & $\mathrm{RICH}$ & ARTH & LEP & FRUIT & RIPE & SEED \\
\hline \multicolumn{14}{|l|}{ Mature-forest frugivores } \\
\hline \multirow[t]{2}{*}{ Veery adults } & 3 & 241.44 & 0.00 & 0.55 & & & & & + & & & & \\
\hline & 4 & 243.53 & 1.96 & 0.19 & & & & & + & & + & & \\
\hline \multirow[t]{2}{*}{ Veery HY } & 3 & 213.94 & 0.00 & 0.28 & - & & & & & & & & \\
\hline & 3 & 214.74 & 0.80 & 0.19 & & & & & & & & + & \\
\hline \multicolumn{14}{|l|}{ Frugivores } \\
\hline \multirow[t]{3}{*}{ All adults } & 3 & 556.84 & 0.00 & 0.33 & & & + & & & & & & \\
\hline & 3 & 556.94 & 0.10 & 0.31 & & & & & & & & - & \\
\hline & 7 & 558.35 & 1.51 & 0.15 & - & - & + & & & & + & - & \\
\hline \multirow[t]{2}{*}{ All HY } & 3 & 415.94 & 0.00 & 0.46 & & & & & & & & + & \\
\hline & 7 & 416.45 & 0.51 & 0.36 & + & - & + & & & & + & + & \\
\hline \multicolumn{14}{|l|}{ Post-breeding adults } \\
\hline \multirow[t]{3}{*}{ Early-successional } & 3 & 368.24 & 0.00 & 0.20 & & & & & - & & & & \\
\hline & 5 & 368.74 & 0.51 & 0.15 & - & + & & & - & & & & \\
\hline & 3 & 368.84 & 0.60 & 0.15 & & + & & & & & & & \\
\hline \multirow[t]{5}{*}{ Mature-forest } & 5 & 471.54 & 0.00 & 0.20 & + & - & & & & & - & & \\
\hline & 3 & 472.34 & 0.79 & 0.14 & & & & & & & - & & \\
\hline & 5 & 472.34 & 0.80 & 0.14 & + & - & - & & & & & & \\
\hline & 3 & 472.44 & 0.89 & 0.13 & & - & & & & & & & \\
\hline & 9 & 472.96 & 1.41 & 0.10 & + & - & - & & - & + & - & + & \\
\hline \multirow[t]{2}{*}{ Species richness } & 3 & 879.84 & 0.00 & 0.51 & & - & & & & & & & \\
\hline & 3 & 881.24 & 1.40 & 0.25 & & & & - & & & & & \\
\hline \multicolumn{14}{|l|}{ Molt index } \\
\hline \multirow[t]{2}{*}{ Adult } & 3 & 412.44 & 0.00 & 0.69 & & & & & & & & + & \\
\hline & 9 & 414.06 & 1.62 & 0.31 & + & + & + & & - & + & + & + & \\
\hline \multirow[t]{2}{*}{ HY } & 3 & 393.84 & 0.00 & 0.26 & & & & & & & + & & \\
\hline & 3 & 395.54 & 1.70 & 0.11 & & & & & + & & & & \\
\hline \multirow[t]{4}{*}{ Body condition index ${ }^{b}$} & 3 & 511.14 & 0.00 & 0.17 & & - & & & & & & & \\
\hline & 3 & 511.64 & 0.50 & 0.13 & & & & & & - & & & \\
\hline & 3 & 511.84 & 0.70 & 0.12 & + & & & & & & & & \\
\hline & 3 & 512.24 & 1.10 & 0.10 & & & & & & & - & & \\
\hline
\end{tabular}

${ }^{\mathrm{a}}$ Independent variables are defined in Table 1.

${ }^{\mathrm{b}}$ This variable was modeled with a normal distribution. 


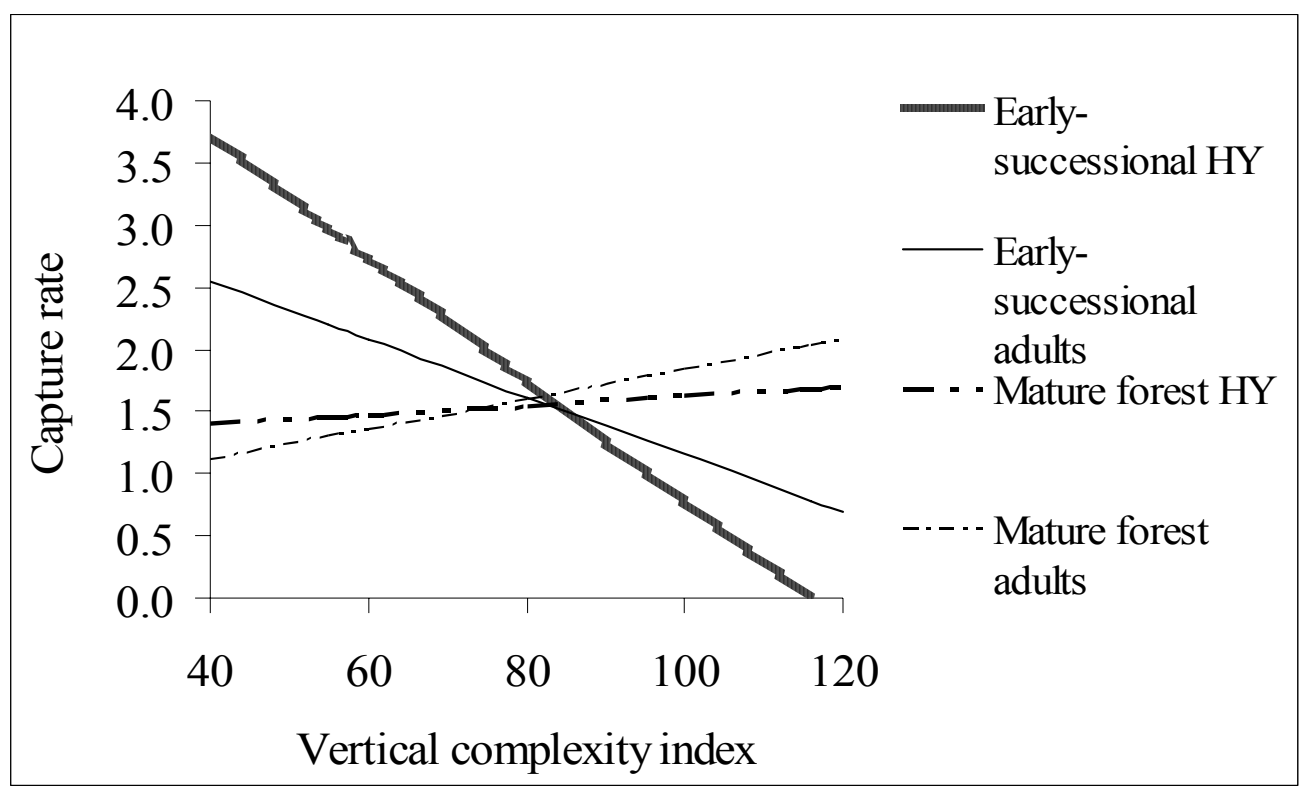

Figure 1. Relationship between capture rate (captures per 100 net-hours) and vertical complexity of the vegetation for mature-forest adult $(\mathrm{Y}=0.0119 \mathrm{x}+0.6402)$ and hatch year $(\mathrm{HY} ; \mathrm{Y}=$ $0.0037 \mathrm{x}+1.2514)$; and early-successional adult $(\mathrm{Y}=-0.0231 \mathrm{x}+3.4625)$ and HY $(\mathrm{Y}=-0.049 \mathrm{x}+$ 5.6745) insectivorous birds in early-successional habitats of north-central West Virginia in 2006. Post-breeding adults had a similar relationship as all adults for both habitat guilds.

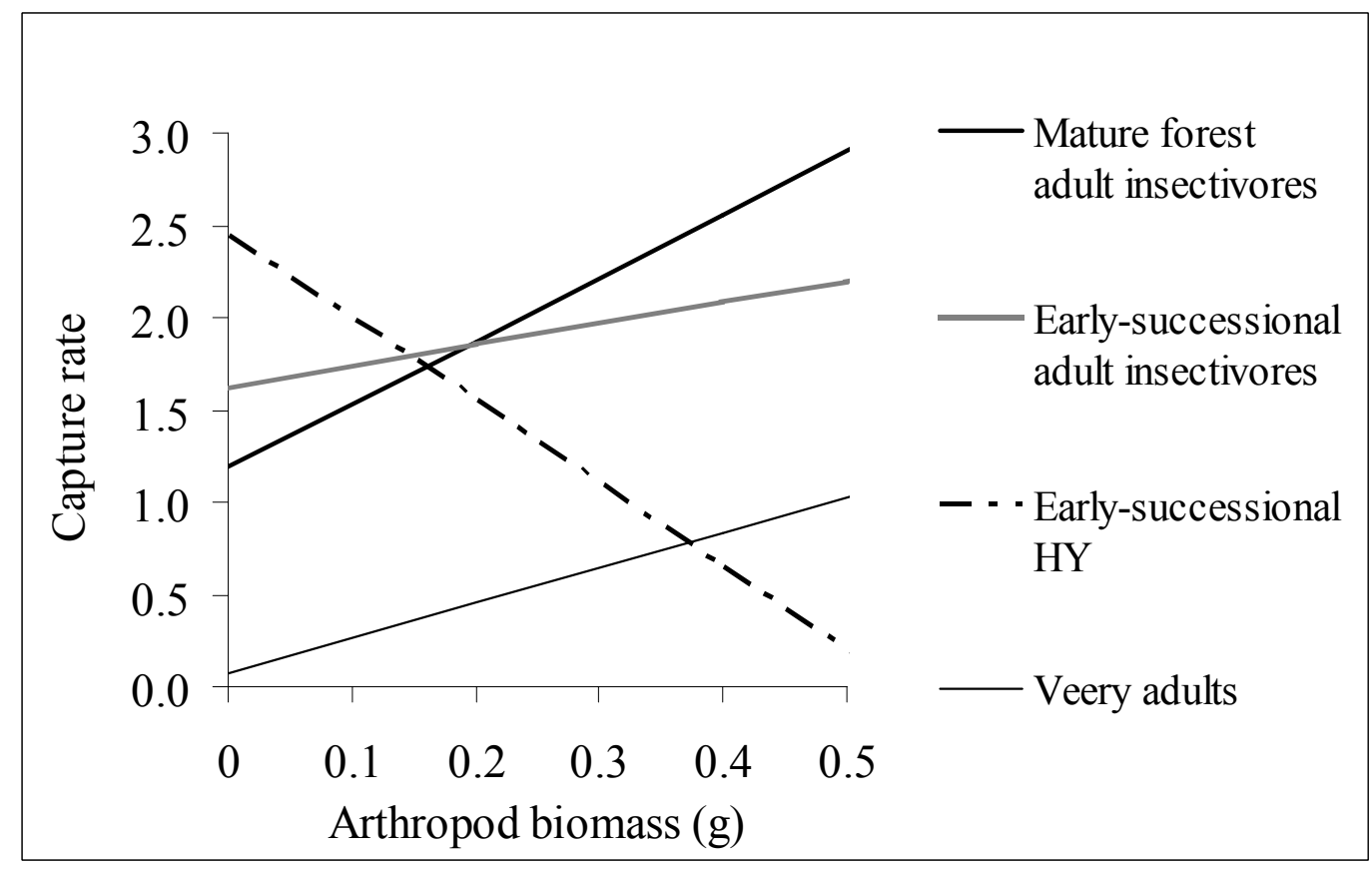

Figure 2. Captures per 100 net-hours as a function of arthropod biomass for all mature-forest (Y $=3.4126 \mathrm{x}+1.1905)$ and early-successional adult insectivores $(\mathrm{Y}=1.165 \mathrm{x}+1.6186)$, adult veeries (seasonal frugivores; $\mathrm{Y}=1.8956 \mathrm{x}+0.0747$ ), and early-successional hatch year $(\mathrm{HY})$ birds $(\mathrm{Y}=-4.4924 \mathrm{x}+2.4502)$ in early-successional habitats of North-central West Virginia in 2006. 


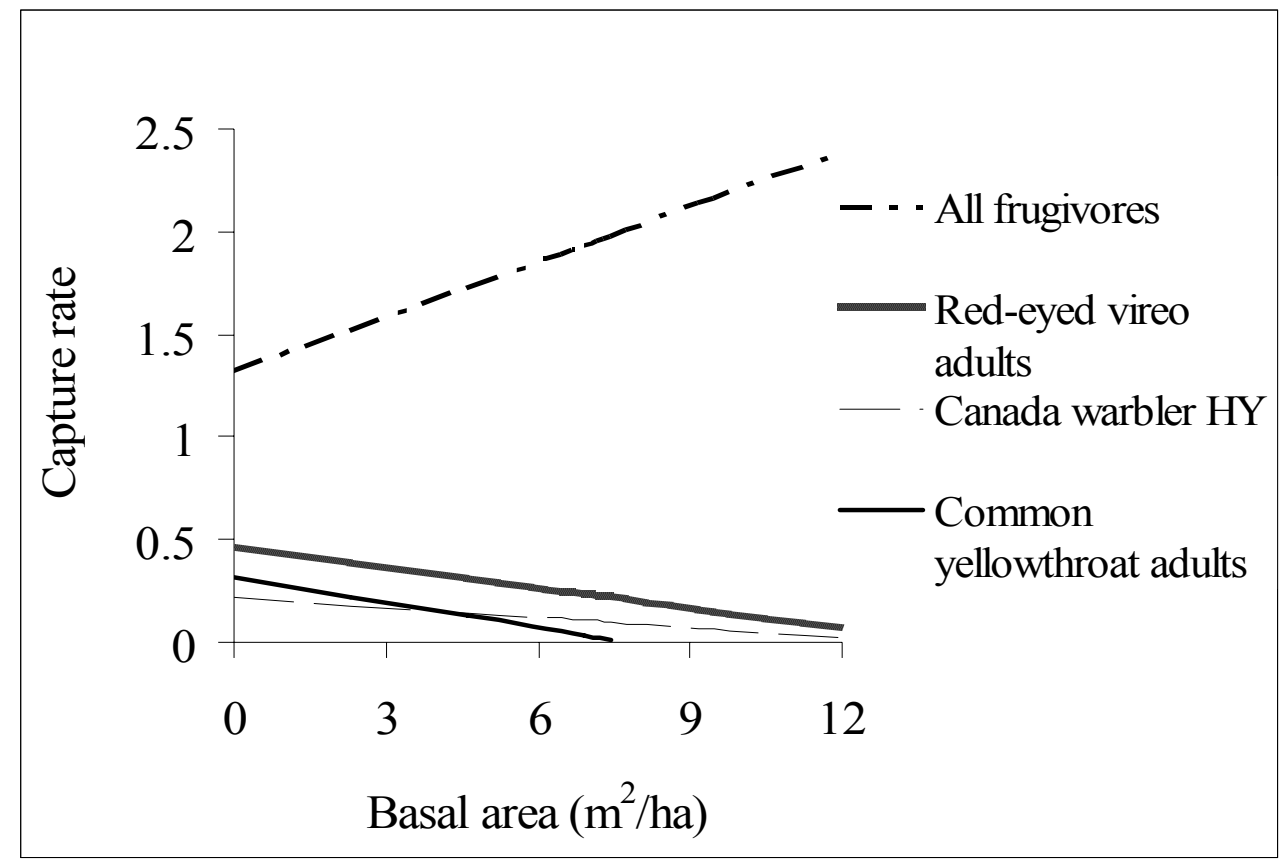

Figure 3. Relationship between capture rate (captures per 100 net-hours) and basal area for all frugivores $(\mathrm{Y}=0.0888 \mathrm{x}+1.319)$, red-eyed vireo adults $(\mathrm{Y}=-0.0322 \mathrm{x}+0.464)$, Canada warbler hatch year $(\mathrm{HY})$ birds $(\mathrm{Y}=-0.016 \mathrm{x}+0.2159)$, and common yellowthroats $(\mathrm{Y}=-0.0414 \mathrm{x}+$ 0.3158 ) in early-successional habitats of north-central West Virginia in 2006.

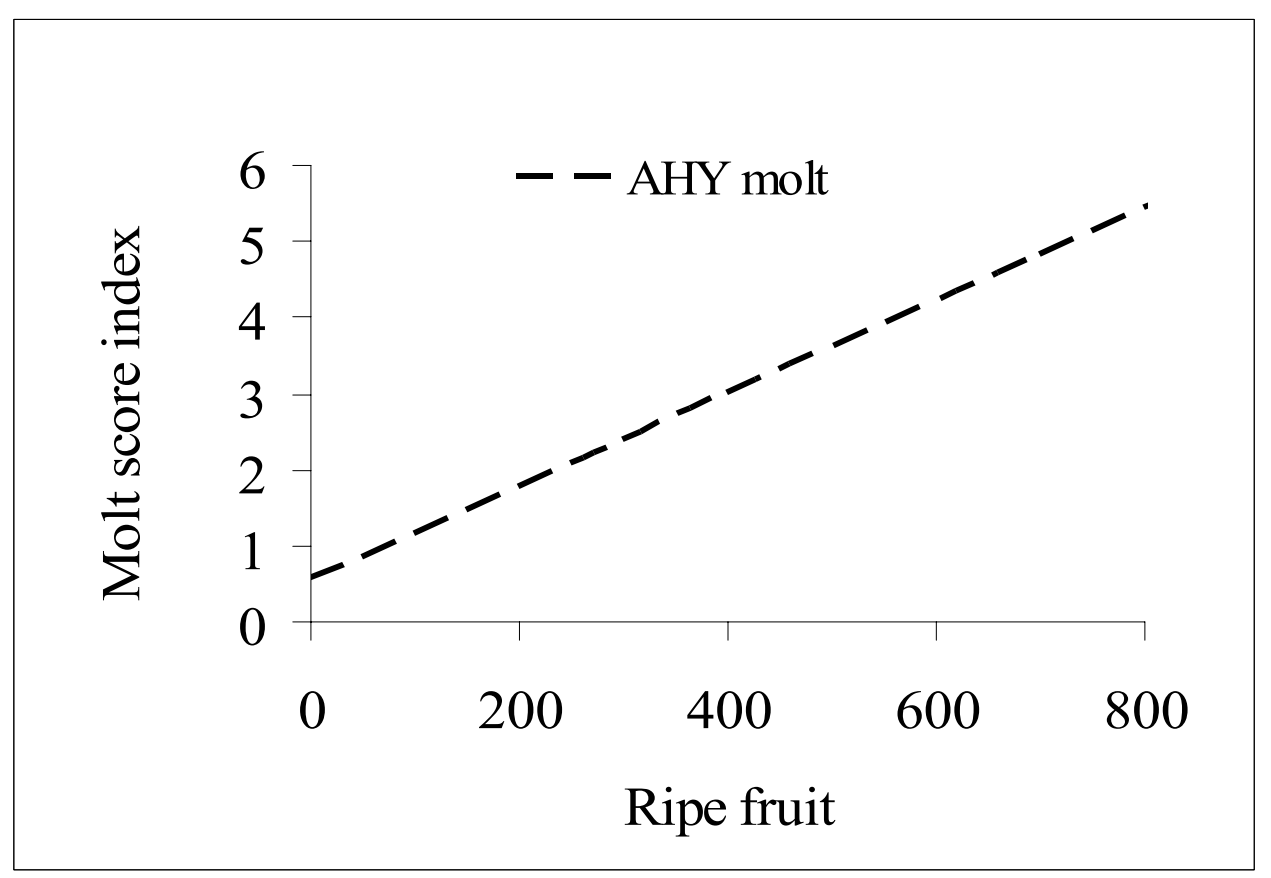

Figure 4. Relationship between ripe fruit and adult (AHY) molt score index $(\mathrm{Y}=0.0061 \mathrm{x}+$ 0.5659) in early-successional habitats of north-central West Virginia in 2006. 


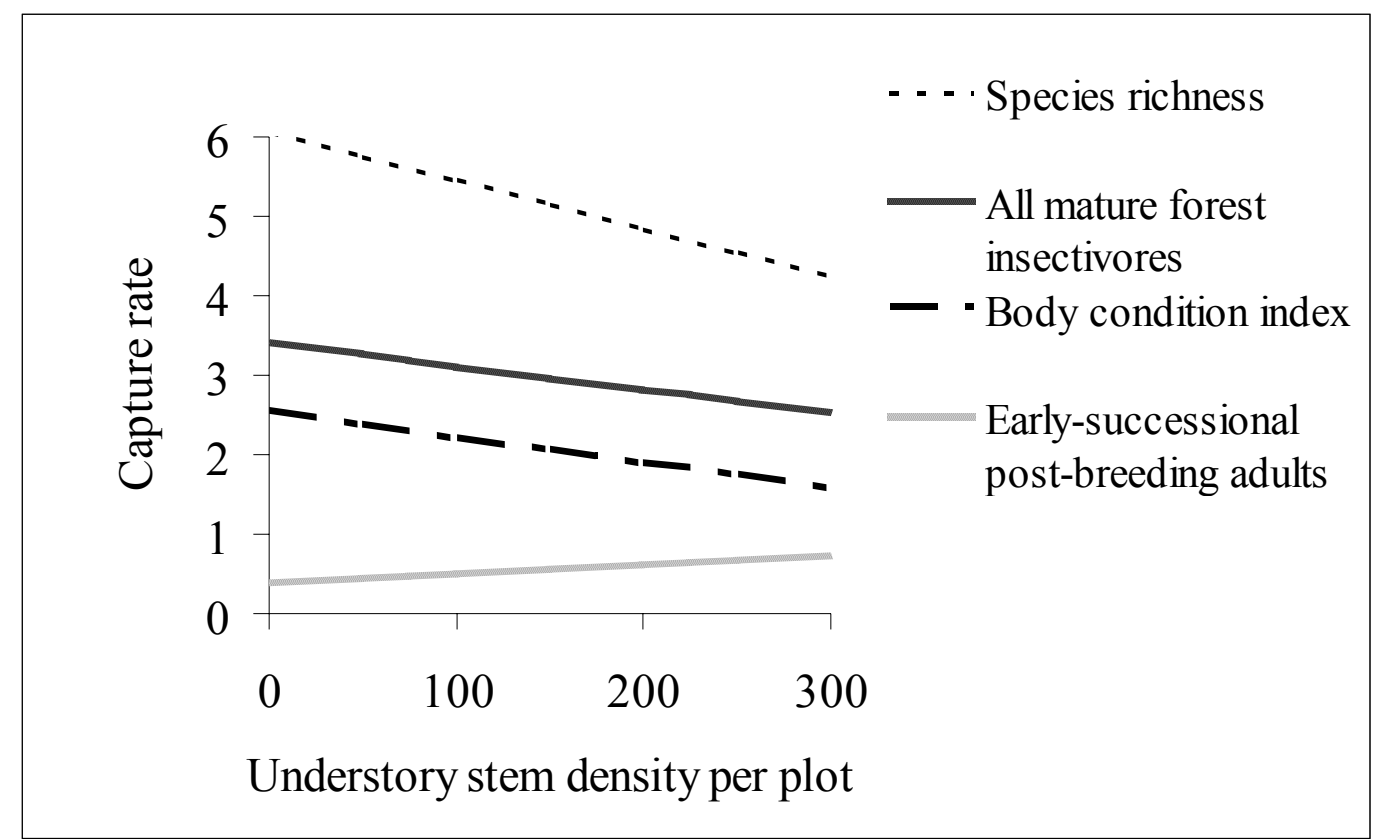

Figure 5. Relationship between capture rate (captures per 100 net-hours) and understory stem density for all mature-forest insectivores $(\mathrm{Y}=-0.0029 \mathrm{x}+3.4177)$ and post-breeding earlysuccessional adults $(\mathrm{Y}=0.0012 \mathrm{x}+0.3862)$ in early-successional habitats of north-central West Virginia in 2006. The relationships between species richness adjusted per 100 net-hours ( $\mathrm{Y}=$ $0.0061 \mathrm{x}+6.0599)$, and body condition index $(\mathrm{Y}=-0.0032 \mathrm{x}+2.5313)$, and stem density are also shown.

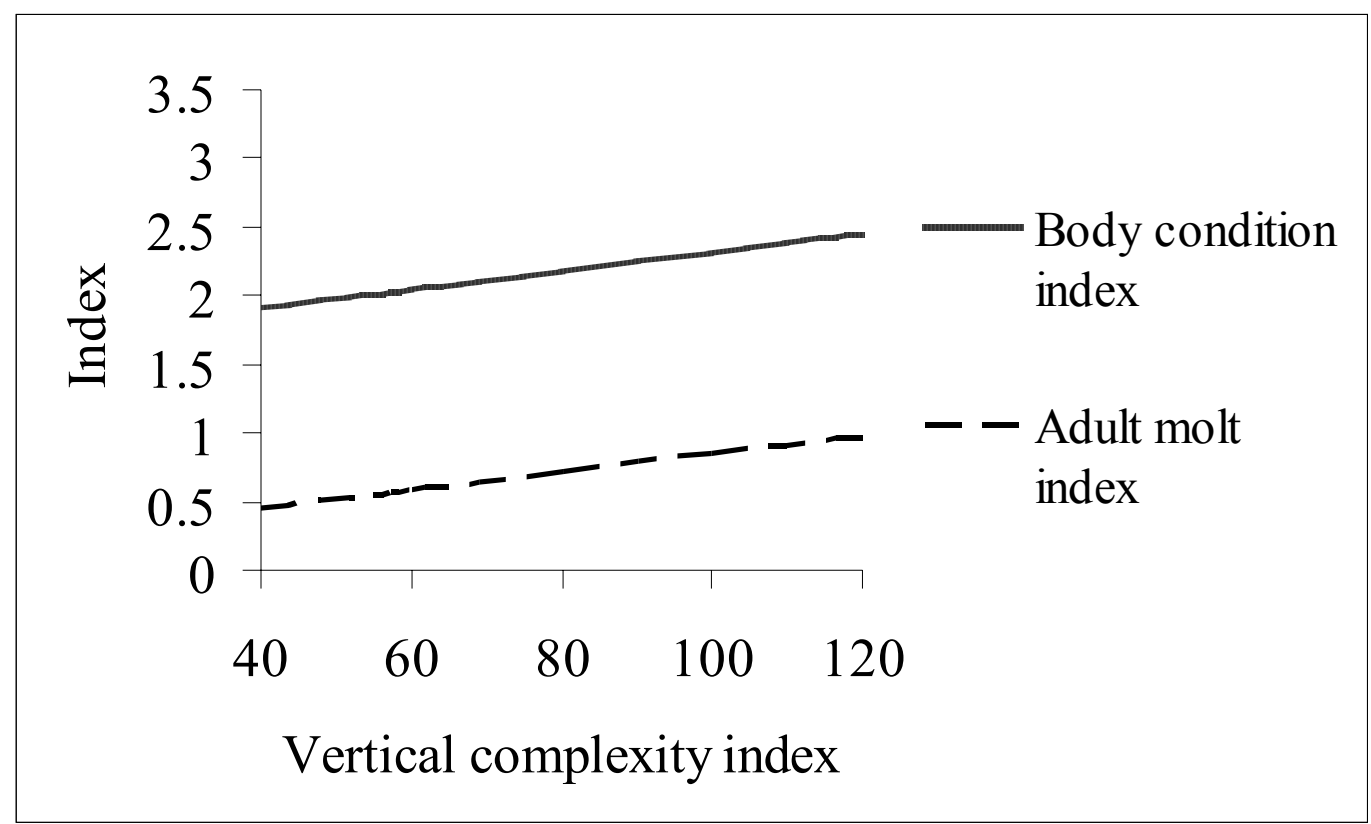

Figure 6. Comparison of indexes of body condition $(\mathrm{Y}=0.0068 \mathrm{x}+1.6306)$ and adult molt $(\mathrm{Y}=$ $0.0064 x+0.2031)$ as related to vertical complexity of the vegetation in early-successional habitats of north-central West Virginia in 2006. 
Appendix 1. Candidate sets of models used for American redstart, Canada warbler, chestnut-sided warbler, common yellowthroat, hooded warbler, and insectivore captures by habitat guild.

\begin{tabular}{lcccccc}
\hline Model & & & & & \multicolumn{2}{c}{ Lepid. } \\
VERT & VCI & density & $\begin{array}{c}\text { Residual } \\
\text { BA }\end{array}$ & $\begin{array}{c}\text { Arthropod } \\
\text { biomass }\end{array}$ & $\begin{array}{c}\text { larvae } \\
\text { biomass }\end{array}$ & K parameters \\
DENSE & $\mathrm{x}$ & & & & & 3 \\
BA & & $\mathrm{x}$ & & & & 3 \\
COVER & $\mathrm{x}$ & $\mathrm{x}$ & $\mathrm{x}$ & & & 3 \\
COVINSECT & $\mathrm{x}$ & $\mathrm{x}$ & & $\mathrm{x}$ & & 5 \\
ARTHBIO & & & & $\mathrm{x}$ & & 5 \\
LEPLBIO & & & & & $\mathrm{x}$ & 3 \\
GLOBAL & $\mathrm{x}$ & $\mathrm{x}$ & $\mathrm{x}$ & $\mathrm{x}$ & $\mathrm{x}$ & 7 \\
\hline
\end{tabular}

Appendix 2. Candidate sets of models used for gray catbird, red-eyed vireo, veery, all post-breeding adults, body condition and molt response variables.

\begin{tabular}{|c|c|c|c|c|c|c|c|c|c|}
\hline Model & VCI & $\begin{array}{c}\text { Stem } \\
\text { density }\end{array}$ & $\begin{array}{c}\text { Residual } \\
\text { BA }\end{array}$ & $\begin{array}{l}\text { Arthropod } \\
\text { richness }_{a} \\
\end{array}$ & $\begin{array}{c}\text { Arthropod } \\
\text { biomass }\end{array}$ & $\begin{array}{c}\text { Lepid. larvae } \\
\text { biomass }\end{array}$ & Total fruit & Total ripe & $\mathrm{K}$ parameters \\
\hline VERT & $\mathrm{x}$ & & & & & & & & 3 \\
\hline DENSE & & $\mathrm{x}$ & & & & & & & 3 \\
\hline BA & & & $\mathrm{x}$ & & & & & & 3 \\
\hline COVER & $\mathrm{x}$ & $\mathrm{x}$ & $\mathrm{x}$ & & & & & & 5 \\
\hline COVFOOD & $\mathrm{x}$ & $\mathrm{x}$ & & & $\mathrm{x}$ & & $\mathrm{x}$ & & 6 \\
\hline COVINSECT & $\mathrm{x}$ & $\mathrm{x}$ & & & $\mathrm{x}$ & & & & 5 \\
\hline COVFRUIT & $\mathrm{x}$ & $\mathrm{x}$ & & & & & $\mathrm{x}$ & & 5 \\
\hline FOOD & & & & & $\mathrm{x}$ & & $\mathrm{x}$ & & 4 \\
\hline FRUIT & & & & & & & $\mathrm{x}$ & & 3 \\
\hline RIPE & & & & & & & & $\mathrm{x}$ & 3 \\
\hline ARTHRICH & & & & $\mathrm{x}$ & & & & & 3 \\
\hline ARTHBIO & & & & & $\mathrm{x}$ & & & & 3 \\
\hline LEPLBIO & & & & & & $\mathrm{x}$ & & & 3 \\
\hline GLOBAL & $\mathrm{x}$ & $\mathrm{x}$ & $\mathrm{x}$ & $\mathrm{x}$ & $\mathrm{x}$ & $\mathrm{x}$ & $\mathrm{x}$ & $\mathrm{x}$ & 10 \\
\hline
\end{tabular}

${ }^{a}$ Arthropod richness used in red-eyed vireo models only.

Appendix 3. Candidate sets of models used for species richness.

\begin{tabular}{|c|c|c|c|c|c|c|c|c|}
\hline Model & VCI & $\begin{array}{l}\text { Stem } \\
\text { density }\end{array}$ & $\begin{array}{c}\text { Residual } \\
\text { BA }\end{array}$ & $\begin{array}{l}\text { Arthropod } \\
\text { richness }\end{array}$ & $\begin{array}{c}\text { Arthropod } \\
\text { biomass }\end{array}$ & Seed & Total fruit & $\begin{array}{c}\mathrm{K} \\
\text { parameters }\end{array}$ \\
\hline VERT & $\mathrm{x}$ & & & & & & & 3 \\
\hline DENSE & & $\mathrm{x}$ & & & & & & 3 \\
\hline BA & & & $\mathrm{x}$ & & & & & 3 \\
\hline COVER & $x$ & $x$ & $\mathrm{x}$ & & & & & 5 \\
\hline COVFOOD & $\mathrm{x}$ & $\mathrm{x}$ & & & $\mathrm{x}$ & & $\mathrm{x}$ & 6 \\
\hline FOOD & & & & & $\mathrm{x}$ & $\mathrm{x}$ & $\mathrm{x}$ & 5 \\
\hline ARTHRICH & & & & $\mathrm{x}$ & & & & 3 \\
\hline GLOBAL & $\mathrm{x}$ & $\mathrm{x}$ & $\mathrm{x}$ & $\mathrm{x}$ & $x$ & $x$ & $x$ & 9 \\
\hline
\end{tabular}


Appendix 4. Candidate sets of models used for frugivore capture rates.

\begin{tabular}{lcccccc}
\multicolumn{1}{c}{ Model } & VCI & $\begin{array}{c}\text { Stem } \\
\text { density }\end{array}$ & $\begin{array}{c}\text { Residual } \\
\text { BA }\end{array}$ & Total fruit & Total ripe & K parameters \\
\hline VERT & $\mathrm{x}$ & & & & & 3 \\
DENSE & & $\mathrm{x}$ & & & & 3 \\
BA & & & $\mathrm{x}$ & & & 3 \\
COVER & $\mathrm{x}$ & $\mathrm{x}$ & $\mathrm{x}$ & & & 5 \\
COVFRUIT & $\mathrm{x}$ & $\mathrm{x}$ & & $\mathrm{x}$ & & 5 \\
FRUIT & & & & $\mathrm{x}$ & & 3 \\
RIPE & & & & & $\mathrm{x}$ & 3 \\
GLOBAL & $\mathrm{x}$ & $\mathrm{x}$ & $\mathrm{x}$ & $\mathrm{x}$ & $\mathrm{x}$ & 7 \\
\hline
\end{tabular}

Appendix 5. Candidate sets of models used for indigo bunting capture rates.

\begin{tabular}{|c|c|c|c|c|c|c|c|c|}
\hline Model & VCI & $\begin{array}{c}\text { Stem } \\
\text { density }\end{array}$ & $\begin{array}{c}\text { Residual } \\
\text { BA }\end{array}$ & Seed & $\begin{array}{l}\text { Arthropod } \\
\text { richness }\end{array}$ & $\begin{array}{c}\text { Arthropod } \\
\text { biomass }\end{array}$ & $\begin{array}{c}\text { Lepid. larvae } \\
\text { biomass }\end{array}$ & $\begin{array}{c}\mathrm{K} \\
\text { parameters }\end{array}$ \\
\hline VERT & $\mathrm{x}$ & & & & & & & 3 \\
\hline DENSE & & $\mathrm{x}$ & & & & & & 3 \\
\hline BA & & & $\mathrm{x}$ & & & & & 3 \\
\hline COVER & $\mathrm{x}$ & $\mathrm{x}$ & $\mathrm{x}$ & & & & & 5 \\
\hline COVINSECT & $\mathrm{x}$ & $\mathrm{x}$ & & & & $\mathrm{x}$ & & 5 \\
\hline COVSEED & $\mathrm{x}$ & $\mathrm{x}$ & & $\mathrm{x}$ & & & & 5 \\
\hline FOOD & & & & $\mathrm{x}$ & & $\mathrm{x}$ & & 4 \\
\hline SEED & & & & $\mathrm{x}$ & & & & 3 \\
\hline ARTHRICH & & & & & $\mathrm{x}$ & & & 3 \\
\hline ARTHBIO & & & & & & $\mathrm{x}$ & & 3 \\
\hline LEPLBIO & & & & & & & $\mathrm{x}$ & 3 \\
\hline GLOBAL & $\mathrm{x}$ & $\mathrm{x}$ & $\mathrm{x}$ & $\mathrm{x}$ & $\mathrm{x}$ & $\mathrm{x}$ & $\mathrm{x}$ & 9 \\
\hline
\end{tabular}


Appendix 6. Biomass of representative orders of arthropods averaged for each net and round. Arthropods were sampled from June through August 2006 in early-successional habitats in north-central West Virginia.

\begin{tabular}{lcc}
\hline Group of measurement & Mean & SE \\
\hline Total individuals $<3 \mathrm{~mm}$ & 46.14 & 2.17 \\
Mass $<3 \mathrm{~mm}(\mathrm{~g})$ & 0.0074 & 0.0003 \\
Total individuals $3-10 \mathrm{~mm}$ & 37.83 & 1.50 \\
Mass 3-10 mm & 0.0622 & 0.0041 \\
Total individuals $>10 \mathrm{~mm}$ & 4.87 & 0.24 \\
Mass $>10 \mathrm{~mm}$ & 0.0305 & 0.0032 \\
Mass all arthropods & 0.1000 & 0.0055 \\
Mass by order or subclass & & \\
Acari & $\mathrm{a}$ & $\mathrm{a}$ \\
Araneae & 0.0048 & 0.0003 \\
Coleoptera & 0.0439 & 0.0040 \\
Collembola & $\mathrm{a}$ & $\mathrm{a}$ \\
Diptera & 0.0006 & 0.0001 \\
Hemiptera & 0.0160 & 0.0022 \\
Homoptera & 0.0076 & 0.0005 \\
Hymenoptera & 0.0065 & 0.0005 \\
Lepidoptera larvae & 0.0162 & 0.0022 \\
Lepidoptera adults & 0.0003 & 0.0001 \\
Mecoptera & 0.0001 & $\mathrm{a}$ \\
Neuroptera & 0.0001 & $\mathrm{a}$ \\
Orthoptera & 0.0025 & 0.0004 \\
Phalangida & 0.0011 & 0.0003 \\
Plecoptera & 0.0001 & $\mathrm{a}$ \\
Psocoptera & 0.0002 & 0.0000 \\
Thysanoptera & $\mathrm{a}$ & $\mathrm{a}$ \\
\hline
\end{tabular}

${ }^{\mathrm{a}}$ Mean/standard error was less than 0.0001 . 


\section{Chapter 4}

\section{Post-breeding bird responses to residual tree retention, stand size, and edge in regenerating stands}

Formatted in the style of Forest Ecology and Management 


\begin{abstract}
Avian use of even-aged timber harvests may be affected by stand attributes such as size, distance to edge, and retained basal area. However, no studies have examined the effects of residual tree retention on post-breeding individuals, and few have studied area and edge-sensitivity. I examined the impacts of clearcut, low-leave two-age and high-leave two-age harvesting on postbreeding birds using transect sampling and mist-netting in north-central West Virginia. Additionally, I studied the effects of stand size and edge on species characteristic of earlysuccessional and late-successional habitats. I compared the results of transect and mist-net surveys and the efficiency of each technique for sampling birds post-breeding. In 2005-2006, 89 stands were sampled with 8-10 nets per stand from late June through mid-August. Because four stands were sampled both years, there were 13 total stands, which ranged from 4-10 years post-harvest and 4-21 ha in size. Capture rates and relative abundance were similar among treatments for generalists and late-successional individuals. Early-successional birds had lower abundance in high-leave two-age stands and were more common in clearcuts. Area sensitivity was evident for both mature-forest and early-successional bird species. Both generalists and late-successional birds were negatively related to stand size, but edge effects were inconclusive, with many species associated with harvest edge. In contrast, early-successional species tended to use stand interiors more often and positively responded to stand size. Despite within-stand edge effects evident for several species, few birds in the forest periphery responded to harvest edge types. To create post-breeding habitat for early-successional birds, large, non-linear openings with a low retained basal area would be best, while variable sizes and increased residual tree retention would provide habitat for more mature-forest birds as well. I found that mist-netting better sampled post-breeding birds using shrub-level vegetation, but transect surveys were important for detecting large species not targeted by mist-nets and those using residual trees. These two techniques were important for helping to determine post-breeding habitat requirements for a variety of species, but understanding stand-specific bird survival is needed to determine the true quality of silvicultural harvests for post-breeding birds.
\end{abstract}




\section{Introduction}

All harvests established through forest management are not identical from an avian perspective. For instance, stand size and configuration can impact bird distribution, density and nesting success within the harvest and in forest adjacent to the harvest (Annand and Thompson 1997; Robinson and Robinson 1999; Costello et al. 2000; King and DeGraaf 2004). Harvest size and shape influence within-stand and periphery edge effects, such as increased nest predation near edge habitat, for certain species (Elliott 1987; Flaspohler et al. 2001; Manolis et al. 2002; Aquilani and Brewer 2004). Additionally, harvest type affects the bird community, because certain species may be sensitive to the amount of residual canopy cover (Chambers et al. 1999; Tittler et al. 2001; Hanowski et al. 2005).

Patterns of post-breeding bird habitat use at the stand scale have recently been investigated in clearcuts (Pagen et al. 2000; Marshall et al. 2003; Rodewald and Vitz 2005). However, research also is needed to examine how residual tree retention impacts post-breeding birds. If residual trees, stand edge, and stand size affect bird habitat use and survival, they should be addressed in silvicultural prescriptions.

Some early-successional species are thought to be area- or edge-sensitive (Rudnicky and Hunter 1993; Hunter et al. 2001; DeGraaf and Yamasaki 2003), so it is important to determine if small open patches created by many silvicultural systems are large enough to support these species in the long-term. Some studies have failed to find a relationship between size of harvested stands and species richness, relative abundance, or reproductive effort for earlysuccessional species (Boardman and Yahner 1999; Krementz and Christie 2000). Clearcut size (ranging from 2 to $52 \mathrm{ha}$ ) did not seem to affect community metrics, and rare birds were no more likely to be detected in large stands than in small ones (Krementz and Christie 2000). Rodewald and Vitz (2005) found only weak evidence for area sensitivity of early-successional species in Ohio, but suggested that shrubland nesters may avoid edges, so small, narrow, or irregularly shaped patches of early-successional habitat may not be suitable for these species. In contrast, Rudnicky and Hunter (1993) found evidence for increased species richness of breeding birds as clearcut size increased from 2 to 20 ha, but resulting edge effects were inconclusive. Some early-successional species are absent from selection cuts $<1$ ha in size but are found in larger openings such as clearcuts (Annand and Thompson 1997, Robinson and Robinson 1999, Costello et al. 2000). 
Despite the data available on area and edge sensitivity of early-successional birds in harvested stands, mature-forest bird use of harvests of varying sizes has not been adequately addressed post-breeding (Vitz and Rodewald 2006). Although Vitz and Rodewald (2006) captured more mature-forest birds in small compared to large clearcuts, clearcut interiors were used more than edges. Mature-forest species have been detected in numbers rivaling edge and early-successional species in these habitats (Vitz and Rodewald 2006, McDermott chapter 3). In addition, many species of mature-forest breeding songbirds disperse to early-successional habitat after the young have fledged (Rappole and Ballard 1987; Pagen et al. 2000; Marshall et al. 2003; Vitz and Rodewald 2006). Thus, stand attributes attractive to mature-forest post-breeders need consideration.

Two-age harvesting is being increasingly used in the management of the Central Appalachian hardwood forests as an alternative to clearcutting (Smith et al. 1989; Miller et al. 1995). During a two-age harvest, approximately 25-50 residual canopy trees are left per ha, and all other stems greater than $2.5 \mathrm{~cm}$ in diameter are cut (Smith et al. 1989). The silvicultural harvest may resemble a seed-tree cut (low-leave two-age) or a shelterwood cut (high-leave twoage) with scattered trees, but unlike these prescriptions, the residual trees remain until the next rotation. Regeneration in two-age harvests is similar to that of clearcuts with stands containing both shade-tolerant and -intolerant tree species important for maintaining stand diversity (Smith et al. 1989; Perkey et al. 1999; Miller et al. 2006). A dominant mature age class of residual trees and a regenerating age class result from the harvest.

The resultant vertical stratification provides habitat for both shrub and canopy-foraging species (Chambers et al. 1999), and two-age harvests have additional conservation benefits for wildlife by retaining mast-producing trees that also serve as nesting and foraging substrates and singing perches (Boardman and Yahner 1999; Duguay et al. 2000). The number of canopy trees retained in these harvests may affect bird community composition (Chambers et al. 1999; Tittler et al. 2001; Hanowski et al. 2005).

Several studies have specifically demonstrated the effects of two-age harvesting on breeding birds, but none has focused on bird habitat use of two-age stands post-breeding. Additionally, post-breeding area and edge sensitivity need further exploration for both earlysuccessional and mature-forest breeders. The objectives of this study were to: (1) compare postbreeding bird communities in stands with different levels of residual tree retention in early 
regeneration, (2) investigate harvest size and edge sensitivity of post-breeding birds, and (3) compare transect surveys and mist-netting as methods for sampling post-breeding communities.

\section{Study Area}

The study was conducted at the Monongahela National Forest (MNF) in Pocahontas, Randolph, and Tucker Counties, and the MeadWestvaco Wildlife and Ecosystem Research Forest (MWERF) in Randolph County, West Virginia. The forests, both actively managed for timber harvesting, are located in the Allegheny Mountains region of the Appalachians and are characterized by narrow, low valleys dissected by northeast-southwest ridges. Elevations of the study area were between 550 and 1,100 m.

Thirteen stands were chosen for the study, and four of these were sampled in both 2005 and 2006. I selected five clearcuts, which rarely retained any overstory trees, four low-leave two-age stands (2.0-3.7 $\mathrm{m}^{2} /$ ha retained basal area), and four high-leave two-age stands (5.3-7.0

$\mathrm{m}^{2} / \mathrm{ha}$ ). Stand age ranged from 4 to 10 years post-harvest. Six stands were located on the MWERF and seven on the MNF. Stand size was between 4.2 and 21 ha.

The principal forest types in the study area were northern Allegheny hardwoods, cove hardwoods, mixed mesophytic, and oak-hickory. Dominant overstory tree species in the study stands included red oak (Quercus rubra), red maple (Acer rubrum), chestnut oak (Q. prinus), and yellow poplar (Liriodendron tulipifera). Other residual tree species present were sugar maple (A. saccharum), hickory (Carya spp.), American beech (Fagus grandifolia), black cherry (Prunus serotina), eastern hemlock (Tsuga canadensis), white oak (Q. alba), and cucumber magnolia (Magnolia acuminata). The most abundant regenerating understory plants were blackberries (Rubus spp.), black birch (Betula lenta), greenbrier (Smilax spp.), American beech, maples, and yellow poplar.

\section{Methods}

\subsection{Mist-netting}

Mist-nets were the primary means of sampling post-breeding bird communities in young harvests in 2005 and 2006, because surveying by vision is difficult in dense vegetation. As many birds are silent and secretive during the post-breeding period, mist-netting may be one of the most reliable methods for sampling birds in this period (Ralph et al. 2004). Furthermore, as most 
vegetation in young regenerating stands is near the height of a standard mist-net, mist-netting is an effective choice for sampling birds in this low vertical structure (Pagen et al. 2000). However, there are a few biases associated with this method, such as interspecific and intraspecific differences in capture probability due to mean flight and flight frequency differences, differences in net location, variability in net tension, and variability in microclimate differences for each net (Remsen and Good 1996).

In the pilot year (2005), I sampled birds in four young (5-6 years post-harvest) and four older (8-10 years post-harvest) stands. Half in each age group were clearcut and half were harvested by two-age methods. In 2006, I sampled only young stands including the four from 2005 and five others (all 4-7 years post-harvest). These stands had varying residual basal area: three clearcuts, three low-leave two-age, and three high-leave two-age. Study design changed between the two years because of low capture rates in older stands that suppressed sample size and differences in capture rates associated with differing levels of residual tree retention in the two-aged stands.

One net station was placed within each stand and consisted of eight nets in 2005 and 10 nets in 2006. Whenever possible, net orientation was similar within and among stands. Generally, net orientation was parallel to the prevailing aspect. Nets were arranged such that distance from edge was variable and a minimum of $20 \mathrm{~m}$ separated the ends of nets. The mistnets were standardized: $12 \mathrm{~m}$ long, $2.6 \mathrm{~m}$ high, and $30 \mathrm{~mm}$ mesh, a size most suitable for small passerines (Heimerdinger and Leberman 1966), especially warblers, which comprise most of the locally breeding individuals in the study area.

I sampled two consecutive days at each net station and visited each station twice between 20 June and 15 August, a generalized post-breeding period. I sampled stations randomly for the first round and then repeated stations in the same order so that second samples at the same station were at least three weeks apart. In 2006, when the sample size for each treatment was equal (3), a stand from each harvest group was randomly chosen for the first round, and I alternated among the three harvest types. The same order (high-leave, low-leave two-age, clearcut) was chosen for each group of three stands in each round. Thus, two stands of the same harvest type were sampled approximately one week apart.

At each station I opened nets at sunrise and closed after approximately four hours (after which time bird activity wanes) except in inclement weather, when stations were not operated. 
Nets were checked every 30 minutes, and I recorded data from all captured individuals including species, age, sex, wing chord, mass, fat, breeding condition, molt status, and time of capture. Captured birds were fitted with USGS aluminum bands (Pyle 1997) except for Ruby-throated Hummingbirds (Archilochus colubris).

\subsection{Transect surveys}

Transect surveys (Ralph et al. 1993) were completed in each mist-net stand concurrent with mist-netting operations in 2005 and 2006. I included transect surveys because these techniques are complementary; transects survey species not targeted by mist-nets (e.g., canopy species, large species), and mist-nets are more likely to detect rare or secretive species due to the passive nature of sampling and lack of observer biases (Karr 1981).

Once during each mist-net round, I walked one transect through the middle of each stand and one along the periphery. Birds detected beyond $50 \mathrm{~m}$ of each transect were omitted from analyses. The periphery transect covered $50 \mathrm{~m}$ outside of and $50 \mathrm{~m}$ inside of the harvested stand. The within-stand observations from this transect were not included in analyses because of spatial overlap with the middle transect. Mist-net lanes were avoided by a buffer of $25 \mathrm{~m}$ to minimize disturbance to the netting process. I covered $100 \mathrm{~m}$ in 10 minutes, and transect surveys lasted 20-30 min. I conducted surveys between sunrise and 0900 hours. During each survey, I recorded for each bird encountered the following data: species, age and sex (if discernible), behavior (foraging, singing, preening, flying, etc.), height in vegetation (if applicable), distance from observer, distance of bird to the closest edge, and time of observation.

\subsection{Habitat variables}

Residual basal area was measured using a 10 factor prism from the center of each mistnet lane. I calculated stand area in hectares from digitized stand data in ArcGIS software (ESRI version 9.1). Vegetation height (m) was measured in the center of each side of the net lane and averaged for each net. Distance to edge was measured from the center of each mist-net lane to the nearest stand edge using a spatially explicit aerial photograph and coordinates for the ends of each mist-net lane taken from a Trimble unit. Distance to edge for each transect bird observation was determined after each survey based on a distance and bearing of each bird from the observer and using an aerial photo of the stand. 


\subsection{Treatment and stand size effects}

I examined stand-level treatment and size effects on mist-net and transect post-breeding bird data. I standardized mist-net captures per 100 net-hours (Karr 1981). Birds that were obvious migrants (i.e., did not breed locally) were eliminated from analyses. Individuals recaptured at any time within the season were excluded. All ages were pooled in analyses because transects did not adequately sample adult and hatch year birds separately. Transect data were adjusted (per 20 minutes) to account for differences in survey duration. Birds detected within $50 \mathrm{~m}$ of the middle transect and located within the stand were included in analyses. For both the mist-net and transect data, I averaged the capture rates and relative abundances over the two rounds (all stands) and two years (for the four stands sampled both years) for each stand.

To examine treatment effects, I used analysis of covariance (ANCOVA), with vegetation height and stand size as covariates, and treatment (clearcut, low-leave two-age, and high-leave two-age) as the main explanatory variable. I examined differences in the least squares means to compare bird metrics among the three treatments (PROC GLM in SAS, SAS Institute 2003). ANCOVA is used when, aside from being affected by a categorical variable (treatment), the response variable is linearly related to a continuous variable (Dowdy et al. 2004). Stand size was included as a covariate in the treatment test and also to determine relationships with stand size after adjusting for treatment and vegetation height. When size was significant, I determined the direction of the relationship by plotting each bird metric against stand size. Vegetation height was included as a covariate because capture rates generally decrease with increasing vegetation height. Vegetation height was averaged for each stand as an index of regeneration. Stand age was not used in analyses because of poor regeneration in a few older stands and exceptional regeneration in some of the younger stands and because it was strongly correlated with vegetation height $(\mathrm{r}=0.83)$.

I analyzed total bird relative abundance or capture rate, overall species richness, and relative abundance/capture rate and species richness of breeding birds for habitat groups (earlysuccessional, generalist, late-successional). Birds were assigned to groups based on Whitcomb et al. (1981), Ehrlich et al. (1988), and observations in West Virginia compiled from previous research (Appendix A). Generalists were defined as those species that are not typically confined to early- or late-successional habitat, use a gradient of seral stages, and often breed in forest with 
an abundance of canopy gaps or open woods. Analyses were also conducted at the species-level for species present in a minimum of $20 \%$ of stands with at least 10 mist-net captures and five transect detections for respective tests. For all statistical tests, I used an a priori alpha level of 0.10 .

The relative proportion of juveniles to adults after the fledging period has often been used as an indicator of reproductive effort (Karr 1981). As an index of recruitment and a possible indicator of habitat quality, I calculated a productivity index for the early-successional species grouped, the generalists grouped, and all species grouped based on age-specific mist-net data. Late-successional species were excluded because of small sample size and a low probability of breeding in the harvests. The productivity index was calculated as the ratio of hatch year (HY; juveniles) to after hatch year birds (AHY; adults) for each stand and averaged over the two rounds. I used ANCOVA to compare the ratio among treatments. Average chronological day was included as a covariate to account for increases in HY bird captures as the post-breeding period progresses. Each chronological day was averaged over two rounds to arrive at an average for each stand and year. Stand size also was included as a covariate. Because annual variations in productivity are often significant, a year effect was included in each model.

\subsection{Edge effects - within stand}

To examine edge effects with mist-net data, I related captures/net hour for each mist-net to distance of each mist-net lane from the edge of the stand with Poisson regression (PROC GENMOD; SAS Institute 2003). For transect data, I examined relative abundance among distance to edge categories ( $5 \mathrm{~m}$ intervals up to $130 \mathrm{~m}$ from the edge, depending on the stand). Because stand size varied among stands so that the gradient of distances differed for each stand, I included stand size in each regression. Vegetative characteristics in regenerating stands appear not to vary with distance to edge (Rodewald and Vitz 2005), such that detectability biases should be minimized and edge effects are not confounded by vegetative differences.

\subsection{Edge effects - periphery}

I examined edge effects on the periphery of stands using data from the periphery transect surveys; mist-netting only occurred within a stand. I examined relative abundance, species richness, and guild abundance in mature forest within $50 \mathrm{~m}$ of the edge of a stand as a function of 
residual basal area, understory vegetation height, and stand size. These three variables were regressed on each response variable using multiple regression with a Poisson distribution.

\section{Results}

I observed 68 bird species by mist-net or transect surveys. Fifty-six species comprised 1,963 individuals captured by mist-nets in 2005 and 2006 (Appendix A). I detected 52 species by transect surveys in the stand interior and 45 in surveys on the periphery; 59 were detected within $50 \mathrm{~m}$ of either type of transect.

Percent early-successional species detections was higher in mist-net surveys and higher in 2006 (Table 1). In contrast, percent generalist detections was higher during transect surveys and in 2005 (when stands were on average older and had less scrub vegetation favored by earlysuccessional species). The percentages of these two habitat guilds were somewhat similar and comprised most of the detections by either method. Percent detections of late-successional birds was similar between years and survey methods (11-13\%).

Although stand-level species richness was similar between methods (Table 1), species composition differed in some respects. Ten species were unique to mist-net sampling and nine species were unique to transect sampling (Appendix A).

\subsection{Treatment effects}

No treatment differences were detected for species richness or overall bird abundance for transect data (Table 2). Similarly, mist-net data showed no differences for species richness, but overall capture rates were higher in clearcuts and low-leave two-age stands compared to highleave stands. For early-successional mist-net species richness and capture rates, the same pattern was evident. Common Yellowthroats (Geothlypis trichas) and Field Sparrows (Spizella pusilla) had their highest capture rates in clearcuts. Capture rates of the other eight species tested did not vary. Early-successional relative abundance by transects did not differ among treatments. The Common Yellowthroat was again most common in clearcuts, but relative abundance of none of the other eight species tested varied.

Generalist capture rates and transect relative abundance did not vary among the three treatments (Table 2). The Canada Warbler (Wilsonia canadensis) was detected by transect methods primarily in low-leave two-age stands, and the Downy Woodpecker (Picoides 
pubescens) was more abundant in two-age stands of either treatment than clearcuts; the other 13 species tested with transect data did not differ. Cedar Waxwing (Bombycilla cedrorum) captures were fewest in high-leave two-age stands; capture rates of the other 11 species tested did not differ.

In general, late-successional captures were higher in the two-age stands (Table 2), though not significant; however, Black-throated Green Warbler (Dendroica virens) capture rate was higher in clearcuts than high-leave two-age stands. The other six late-successional species analyzed had similar capture rates among treatments. Relative abundance and species richness of late-successional birds detected by transect surveys were greatest in high-leave stands compared to the other two treatments. Three late-successional species detected by transect surveys that were analyzed had no significant differences among treatments. The productivity index did not differ among treatments for all birds, early-successional species, or generalist species (Table 2).

\subsection{Stand size effects}

There was no trend in species richness or relative abundance of all birds related to stand size for either data set (Table 2). Early-successional species, the Field Sparrow, and Eastern Towhee (Pipilo erythrophthalmus) showed area sensitivity from mist-net data; capture rates were positively associated with stand size (Figure 1). The same pattern was detected with transect data for all early-successional birds (Figure 2), but it was not statistically significant $(P=0.16)$. Common Yellowthroat and Song Sparrow (Melospiza melodia) relative abundances were positively related to stand size.

For both analyses (transect and mist-net data) generalists were negatively associated with stand size (Table 2, Figures 1,2). All species with a significant result from at least one data set showed this relationship (American Redstart (Setophaga ruticilla), Cedar Waxwing, Rubythroated Hummingbird, and Veery (Catharus fuscescens)).

Late-successional individuals detected by transects were also negatively related to stand size (Table 2, Figure 2), but no species tested by this method differed. Mist-net captures of two late-successional species, Scarlet Tanager (Piranga olivacea) and Worm-eating Warbler (Helmitheros vermivorus), were negatively associated with stand size. 
Productivity index did not show a significant relationship with stand size for any guild analyzed (Table 2). However, for generalists, the productivity index was highest in small stands $(P=0.17)$.

\subsection{Edge effects - within stand}

No significant edge sensitivity was detected for overall mist-net capture rate, species richness, or capture rates of the three habitat guilds (Table 3). With transect data, earlysuccessional relative abundance and species richness increased with increasing distance from the edge.

Eastern Phoebe (Sayornis phoebe) and Field Sparrow captures were associated with the middle of stands, while Song Sparrow captures were associated with edges (Table 3). Based on transect surveys, the American Goldfinch (Carduelis tristis), Common Yellowthroat, Field Sparrow, and Mourning Warbler (Oporornis philadelphia) were less common near forest edge.

Only one generalist tested with mist-net data showed edge effects; the Downy Woodpecker was positively associated with distance to edge (Table 3 ). Transect data provide evidence for mixed effects. Canada Warblers and Ruby-throated Hummingbirds were positively associated with distance to edge, whereas Northern Flickers (Colaptes auratus), Rose-breasted Grosbeaks (Pheucticus ludovicianus), and Wood Thrushes (Hylocichla mustelina) were negatively associated with distance to edge and were less likely to occur in the middle of a stand.

Black-throated Blue Warbler (Dendroica caerulescens) and Black-throated Green Warbler capture rates were negatively associated with distance to edge, whereas Ovenbirds (Seiurus aurocapillus) showed the opposite pattern (Table 3). Few late-successional species detected by transect surveys had a high enough sample size for analysis; none were statistically significant.

\subsection{Edge effects - periphery}

Relative abundance of all birds detected within $50 \mathrm{~m}$ of the harvest edge, species richness, and habitat guild abundance were not affected by stand size, basal area, or vegetation height (Table 4). Early-successional species were less likely to be found on the edge of large stands and older stands (possible spillover effect for small stands); but none analyzed individually were statistically significant. Blue Jays (Cyanocitta cristata) were associated with 
the edge of stands with higher regeneration. White-breasted Nuthatch (Sitta carolinensis) relative periphery abundance was negatively associated with size and vegetation height of adjacent harvest. Scarlet Tanager periphery abundance was positively associated with vegetation height.

\section{Discussion}

\subsection{Two-age harvesting and residual trees}

High amounts of residual canopy depressed use of harvested stands by early-successional species during post-breeding. High-leave two-age harvests provided some post-breeding habitat for these birds, but capture rates, species richness, and relative abundance were greater in clearcut and low-leave two-age stands. Residual basal area was 5.3-7.0 $\mathrm{m}^{2} / \mathrm{ha}$ in high-leave and $2.0-3.7 \mathrm{~m}^{2} /$ ha in low-leave suggesting that retaining stand basal area between 3.7 and $5.3 \mathrm{~m}^{2} / \mathrm{ha}$ renders stands less suitable for early-successional species. Only the Common Yellowthroat and Field Sparrow were less common two-age stands; my data suggest that these species are sensitive to presence of residual trees (McDermott chapter 3).

Generalists had similar capture rates, species richness, and relative abundance among all three basal area treatments based on both mist-net and transect data. Only the Cedar Waxwing showed a response to residual basal area; this species had low capture rates in high-leave twoage stands, but they were likely using canopy trees instead of understory.

Residual trees appear to increase post-breeding suitability of harvests for mature-forest birds through increased vertical stratification. Late-successional species were detected by sight and sound more frequently in high-leave two-age stands and reached their highest relative abundance and species richness in these stands. In contrast, habitat use was similar for this guild among the three basal area treatments based on mist-nets, which sample primarily the understory. In two-age harvests, understory habitat use may be similar to that of clearcuts, but the residual trees provide additional habitat for more mature-forest individuals and species. One species, the Black-throated Green Warbler, reached its highest capture rate in clearcuts. Possibly, this species used the residual trees in two-age stands more than the understory, accounting for lower understory capture rates in this harvest type compared to clearcuts, which lacked trees. The sample size from transect data was too low for comparison. 


\subsection{Area and edge sensitivity}

Stand area-sensitivity was evident for all three habitat guilds, although the direction of the response varied. Early-successional species had a positive relation to stand size, while generalists and late-successional species generally had a negative relation to stand size. Although harvests of 10-15 ha may be a good compromise for early-successional and generalist species, stands $<10$ ha in size would probably support more late-successional post-breeders (Figure 1,2). However, this guild comprised the smallest proportion of captures/transect detections.

Overall, early-successional species had a higher capture rate in large stands, and Common Yellowthroats, Field Sparrows, and Song Sparrows in particular were possibly affected by stand size. Furthermore, although not statistically significant $(P=0.14)$, species richness of this guild increased with increasing stand size. Rudnicky and Hunter (1993) found similar relationships with stands ranging from 2-20 ha in size. Stands in my study were 4-21 ha. Large stands may be more heterogeneous (Freemark and Merriam 1986), have a richer or more plentiful food supply (Zanette et al. 2000), support species with larger territory requirements (Rudnicky and Hunter 1993), or support species that exhibit conspecific attraction (Fletcher 2006). Some area-sensitivity could be accounted for by increased proximity to edge in small stands.

Rodewald and Vitz (2005) found that most shrubland species avoided mature forest edge, indicating that harvest shape may be as important as harvest size for this guild. Similarly many early-successional birds in my study (5 of 10 tested) occurred less often near edges of stands; only the Song Sparrow used edges more based on mist-net data. This species is not a scrubshrub specialist and is often associated with edge habitats (Ehrlich et al. 1988).

Generalists and some late-successional birds had a negative response to stand size. Vitz and Rodewald (2006) also found that mature-forest (generalist and late-successional) birds were less common in large harvests. In both their study and mine, Scarlet Tanager capture rates were highest in small stands. Five species were negatively related to stand size with mist net data; however, only 1 species, the Ruby-throated Hummingbird, had a significant area effect with both mist-net and transect data in my study. As Vitz and Rodewald (2006) suggested, these species probably use both early-successional and mature forest habitat post-breeding, and smaller stands 
not only allow increased access to both types of forest, but are likely surrounded by more mature forest in the surrounding landscape.

Some late-successional species were likely to be associated with stand edge, the opposite pattern detected in the Ohio study (Vitz and Rodewald 2006), in which clearcut interiors were used more than edges by mature-forest birds. I found that the Ovenbird was often absent near harvest edges, and several species that showed a significant edge effect were more common in harvest interiors. But the Black-throated Blue Warbler and Black-throated Green Warbler were captured more near harvest edges. In the Ohio study, where the landscape was more fragmented, predation on forest edges may be a more significant mortality factor than in West Virginia, thus accounting for this difference. Distinct edge effects may be less pronounced in extensively forested regions, and in quickly regenerating hardwood forests, these effects (if present) are ephemeral for mature-forest birds (DeGraaf 1992).

I explored periphery habitat use to determine if a particular treatment, regeneration height, or stand size was likely to deter or attract individuals to forest on the harvest periphery. Few species were affected by stand size or by regeneration stage as measured by vegetation height; the range for my study was narrow because stand ages ranged from 4 to 10 years. Also, silvicultural treatment did not seem to affect relative abundance of birds on the stand periphery. However, I did not collect data at greater distances from stand edges to determine if edge effects could penetrate farther into the forest.

\subsection{Productivity}

The productivity index did not vary among treatments; there was no indication that the productivity ratio in clearcuts differed from that in two-age stands for any group analyzed. Generalist productivity was weakly affected by stand size. Thus, the higher use of smaller stands may be explained in part by the productivity ratio; this guild may have lower recruitment in large harvests. Alternatively, young birds may move far from natal areas post-breeding (Anders et al. 1998, Vega Rivera et al. 1998, T. Dellinger, unpublished data), in which case hatch year bird captures may not represent local recruitment. Recently fledged young were rarely captured by mist-nets. Studies of nesting success and post-fledging survival in small vs. large stands are needed for definitive evidence. 


\subsection{Post-breeding sampling techniques}

Communities sampled by mist-netting and transect surveys were similar in species composition, but they also sampled somewhat unique communities. Transects uniquely sampled corvids, other birds too large to be caught in the mesh size used (e.g., Mourning Dove (Zenaida macroura), Ruffed Grouse (Bonasa umbellus)), and some uncommon canopy-dwelling species such as the Blue-headed Vireo (Vireo solitarius), Eastern Wood-Pewee (Contopus virens) and Yellow-bellied Sapsucker (Sphyrapicus varius). The White-breasted Nuthatch, a bark-foraging species that does not forage in the understory, was almost exclusively sampled by transects. Woodpeckers were undersampled by mist-nets because of their large size, and some species infrequently forage in the understory. Large passerines such as the American Robin (Turdus migratorius) and Eastern Towhee were also undersampled by mist-nets. Transect surveys had the disadvantage of low numbers of definitive post-breeding birds because of the difficulty in detecting post-breeders by sight or sound. Although large species and those likely to use residual trees were detected, many were breeding or territorial individuals.

The main disadvantage of mist-netting was the inability to sample the mid- and overstory, important habitat components in two-age stands. However, post-breeding bird understory use was well sampled. Mist-nets were more likely to sample rare species (e.g., Blackburnian Warbler (Dendroica fusca), Brown Creeper (Certhia americana), and Northern Cardinal (Cardinalis cardinalis)), migrants (Tennessee Warbler (Vermivora peregrine) and Yellow Warbler (Dendroica petechia)) or secretive birds that are non-territorial. The Canada Warbler, one of the first warblers to terminate breeding in the study area, was likely sampled better by mist-nets because a higher percentage of birds were post-breeding; thus, less territorial and less detectable.

Notably, early-successional species were better sampled by mist-nets, and only with this technique did I detect treatment and area effects. Conversely, generalists were better sampled by transect surveys in terms of proportion of total detections, and mist-nets in terms of total sample size, but neither technique detected differences in the two analyses. Late-successional birds were sampled in equal proportions between techniques, but differences were only detected by transects. Both techniques were complementary in terms of sampling the harvest communities, and mist-netting was the better for sampling more secretive post-breeding birds. Multiple techniques should be incorporated when sampling post-breeding bird communities in complex 
habitat types. More thorough techniques to sample post-breeders in residual canopy trees need to be developed.

\section{Management Implications}

Mature-forest and early-successional birds are both components of early-successional habitats post-breeding and readily used both clearcuts and two-age stands. During my study, I captured 39 species of mature-forest birds vs. 32 (Vitz and Rodewald 2006) and 24 (Marshall et al. 2003) in other studies from mist-netting in regenerating stands. An additional seven matureforest species were sampled during transect surveys and several more were casually observed in the study stands. These relatively high species totals probably reflect a large elevational gradient and the additional habitat offered by residual trees for mature-forest birds in two-age stands. Implementing harvests with a gradient of residual basal areas would support the highest number

of post-breeding species; and stands retaining $<5 \mathrm{~m}^{2} /$ ha (i.e., clearcut or low-leave two-age) may be best for early-successional birds, which are increasingly habitat-limited in many regions. Stands with lower basal area not only support more early-successional species and individuals, but also will more likely regenerate shade-intolerant tree species in the long-term (Miller et al. 2006).

I found evidence that large stands that minimize edge will support more earlysuccessional species and individuals, while mature-forest post-breeders may respond negatively to stand size but not necessarily edge. To maximize diversity of post-breeding birds at a landscape scale, harvest size diversity should be factored into prescriptions, with an emphasis on large openings (>10-15 ha, which should support area-sensitive species sampled in this study) for early-successional birds. I did not thoroughly sample post-breeding use of adjacent forest, and peripheral effects were inconclusive. Thus, mature-forest bird post-breeding survival may differ within and adjacent to a harvest and should be further examined before making harvest recommendations for this group, which likely is not habitat-limited in an extensively forested landscape like my study area.

Most bird species in this study were detected by both survey methods. Managers with limited time and resources would benefit from use of transect surveys to get a quick estimate of bird communities that may use these stands during breeding and post-breeding periods. Mistnetting and transect surveys were important for determining post-breeding habitat requirements 
for a variety of species. However, understanding stand-specific bird survival is needed to determine the true quality of silvicultural harvests for post-breeding birds.

\section{References}

Anders, A.D., Faaborg, J., Thompson III, F.R., 1998. Postfledging dispersal, habitat use, and home-range size of juvenile Wood Thrushes. Auk 115, 349-358.

Annand, E.M., Thompson III, F.R., 1997. Forest bird response to regeneration practices in Central hardwood forests. Journal of Wildlife Management 61, 159-171.

Aquilani, S.M., Brewer, J.S., 2004. Area and edge effects on forest songbirds in a nonagricultural upland landscape in northern Mississippi, USA. Natural Areas Journal $24,326-335$.

Boardman, L.A., Yahner, R.H., 1999. Wildlife communities associated with even-aged reproduction stands in two state forests of Pennsylvania. Northern Journal of Applied Forestry 16, 89-95.

Chambers, C.L., McComb, W.C., Tappeiner II, J.C., 1999. Breeding bird responses to three silvicultural treatments in the Oregon Coast Range. Ecological Applications 9, 171-185.

Costello, C.A., Yamasaki, M., Pekins, P. J., Leak, W.B., Neefus, C.D., 2000. Songbird response to group selection harvests and clearcuts in a New Hampshire northern hardwood forest. Forest Ecology and Management 127, 41-54.

DeGraaf, R.M., 1992. Effects of even-aged management on forest birds at northern hardwood stand interfaces. Forest Ecology and Management 46, 95-110.

DeGraaf, R.M., Yamasaki, M., 2003. Options for managing early-successional forest and shrubland bird habitats in the northeastern United States. Forest Ecology and Management 185, 179-191.

Dowdy, S., Wearden, S., Chilko, D, 2004. Statistics for Research, third edition. John Wiley \& Sons, Hoboken, New Jersey.

Duguay, J.P., Wood, P.B., Miller, G.W., 2000. Effects of timber harvests on invertebrate biomass and avian nest success. Wildlife Society Bulletin 28, 1123-1131.

Ehrlich, P.R., Dobkin, D.S., Wheye, D., 1988. The birder's handbook. Simon and Schuster, New York. 
Elliot, C.A., 1987. Songbird species diversity and habitat use in relation to vegetation structure and size of forest stands and forest-clearcut edges in north-central Maine. Dissertation. University of Maine, Orono, Maine.

Flaspohler, D.J., Temple, S.A., Rosenfield, R.N., 2001. Species-specific edge effects on nest success and breeding bird density in a forested landscape. Ecological Applications $11,32-46$.

Fletcher, R.J., 2006. Emergent properties of conspecific attraction in fragmented landscapes. American Naturalist 168, 207-219.

Freemark, K.E., Merriam, H.G., 1986. Importance of area and habitat heterogeneity to bird assemblages in temperate forest fragments. Biological Conservation 36, 115-141.

Hanowski, J., Danz, N., Lind, J., Niemi, G., 2005. Breeding bird response to varying amounts of basal area retention in riparian buffers. Journal of Wildlife Management 69, 689-698.

Heimerdinger, M.A., Leberman, R.C., 1966. The comparative efficiency of 30 and $36 \mathrm{~mm}$ mesh mist nets. Bird-Banding 37, 280-285.

Hunter, W.C., Buehler, D.A., Canterbury, R.A., Confer, J.L., Hamel, P.B., 2001. Conservation of disturbance-dependent birds in eastern North America. Wildlife Society Bulletin 29, 440-455.

Karr, J.R. 1981. Surveying birds with mist nets. In: Ralph, C.J., Scott, J.M. (Eds.), Estimating numbers of terrestrial birds. Studies in Avian Biology 6, pp. 62-67.

King, D.I. DeGraaf, R.M., 2004. Effects of group-selection opening size on the distribution and reproductive success of an early-successional shrubland bird. Forest Ecology and Management 190, 179-185.

Krementz, D.G., Christie, J.S., 2000. Clearcut stand size and scrub successional bird assemblages. Auk 117, 913-924.

Manolis, J.C., Andersen, D.E., Cuthbert, F.J., 2002. Edge effect on nesting success of ground nesting birds near regenerating clearcuts in a forest-dominated landscape. Auk 119, 955-970.

Marshall, M.R., DeCecco, J.A. , Williams, A.B., Gale, G.A., Cooper, R J., 2003. Use of regenerating clearcuts by late-successional bird species and their young during the postfledging period. Forest Ecology and Management 183, 127-135. 
Miller, G.W., Wood, P.B., Nichols, J.V., 1995. Two-age silviculture: an innovative tool for enhancing species diversity and vertical structure in Appalachian hardwoods. In: Eskew, L.G., (compiler). Forest health through silviculture. Proceedings of the 1995 national silviculture workshop. General technical report RM-GTR-267. U.S. Forest Service, Rocky Mountain Forest and Range Experiment Station, Fort Collins, Colorado, pp. 175182.

Miller, G.W., Kochenderfer, J.N., Fekedulegn, D.B., 2006. Influence of individual reserve trees on nearby reproduction in two-aged Appalachian hardwood stands. Forest Ecology and Management 224, 241-251.

Pagen, R.W., Thompson III, F.R., Burhans, D.E., 2000. Breeding and post-breeding habitat use by forest migrant songbirds in the Missouri Ozarks. Condor 102, 738-747.

Perkey, A.W., Miller, G.W., Schuler, T.M., 1999. Regeneration results using twoaged management. Forest Management Update 19, 1-9.

Pyle, P., 1997. Identification guide to North American birds. Slate Creek Press, Bolinas, California.

Ralph, C.J., Geupel, G.R., Pyle, P., Martin, T.E., DeSante, D.F., 1993. Handbook of field methods for monitoring landbirds. General technical report PSW-GTR-144. U.S. Forest Service, Pacific Southwest Research Station, 41 p.

Ralph, C.J., Dunn, E.H., Peach, W.J., Handel, C.M., 2004. Recommendations for the use of mist nets for inventory and monitoring of bird populations. In: Ralph, C.J., Dunn, E.H. (Eds.), Monitoring bird populations using mist nets. Studies in Avian Biology 29, pp. 187-196.

Rappole, J.H. Ballard, K., 1987. Postbreeding movements of selected species of birds in Athens, Georgia. Wilson Bulletin 99, 475-480.

Remsen, J.V. Jr., Good, D.A., 1996. Misuse of data from mist-net captures to assess relative abundance in bird populations. Auk 113, 381-398.

Robinson, W.D., Robinson, S.K., 1999. Effects of selective logging on forest bird populations in a fragmented landscape. Conservation Biology 13, 58-66.

Rodewald, A.D., Vitz, A.C., 2005. Edge- and area-sensitivity of shrubland birds. Journal of Wildlife Management 69, 681-688.

Rudnicky, T.C., Hunter Jr., M.L., 1993. Reversing the fragmentation perspective: effects of clearcut size on bird species richness in Maine. Ecological Applications 3, 357-366.

SAS Institute, 2003. SAS/STAT users guide. Version 9.1. SAS Institute, Cary, North Carolina. 
Smith, H.C., Lamson. N.I., Miller, G.W., 1989. An esthetic alternative to clearcutting? Journal of Forestry 87, 14-18.

Tittler, R., Hannon, S.J., Norton, M.R., 2001. Residual tree retention ameliorates short-term effects of clear-cutting on some boreal songbirds. Ecological Applications 11, 16561666.

Vega Rivera, J.H., Rappole, J.H., McShea, W.J., Haas, C.A., 1998. Wood Thrush postfledging movements and habitat use in northern Virginia. Condor 100, 69-78.

Vitz, A.C., Rodewald, A.D., 2006. Can regenerating clearcuts benefit mature-forest songbirds? An examination of post-breeding ecology. Biological Conservation 127, 477-486.

Whitcomb, R.F., Robbins, C.S., Lynch, J.F., Klimkiewicz, B.L., Bystrak, D., 1981. Effects of forest fragmentation on avifauna of the eastern deciduous forest. In: Burgess, R.L., Sharpe, D.M. (Eds.), Forest island dynamics in man-dominated landscapes. Springer-Verlag, New York, pp. 125-206.

Zanette, L., Doyle, F., Tremont, S.M., 2000. Food shortage in small fragments: evidence from an area-sensitive passerine. Ecology 81, 1654-1666. 
Table 1. Mean ( \pm SE) species richness and number of individuals encountered by mist-net and transect surveys per station, year, round and habitat guild and the and proportion of each guild in north-central West Virginia during 2005-2006.

\begin{tabular}{lcccc} 
& 2005 & 2006 & 2005 & 2006 \\
\hline Transect & & & & \\
Species richness & $17.4(0.6)$ & $16.4(1.4)$ & & \\
Early-successional relative abundance & $9.9(1.6)$ & $12.6(1.2)$ & $38 \%$ & $45 \%$ \\
Generalist relative abundance & $12.9(0.6)$ & $12.3(1.4)$ & $49 \%$ & $44 \%$ \\
Late-successional relative abundance & $3.4(0.9)$ & $3.1(0.8)$ & $13 \%$ & $11 \%$ \\
& & & & \\
Mist-net & & & & \\
Species richness & $15.1(1.3)$ & $17.8(0.9)$ & & \\
Early-successional captures & $23.1(4.5)$ & $34.3(2.6)$ & $48 \%$ & $53 \%$ \\
Generalist captures & $19.4(2.5)$ & $22.6(2.5)$ & $41 \%$ & $35 \%$ \\
Late-successional captures & $5.2(1.1)$ & $8.1(1.1)$ & $11 \%$ & $12 \%$ \\
\hline
\end{tabular}


Table 2. Mean $( \pm$ SE) bird metrics per station, round and year (2005 and 2006) sampled by transect and mist-net surveys in West Virginia. Only species with a significant treatment or area effect $(P \leq 0.10$; indicated by bold face $)$ are presented.

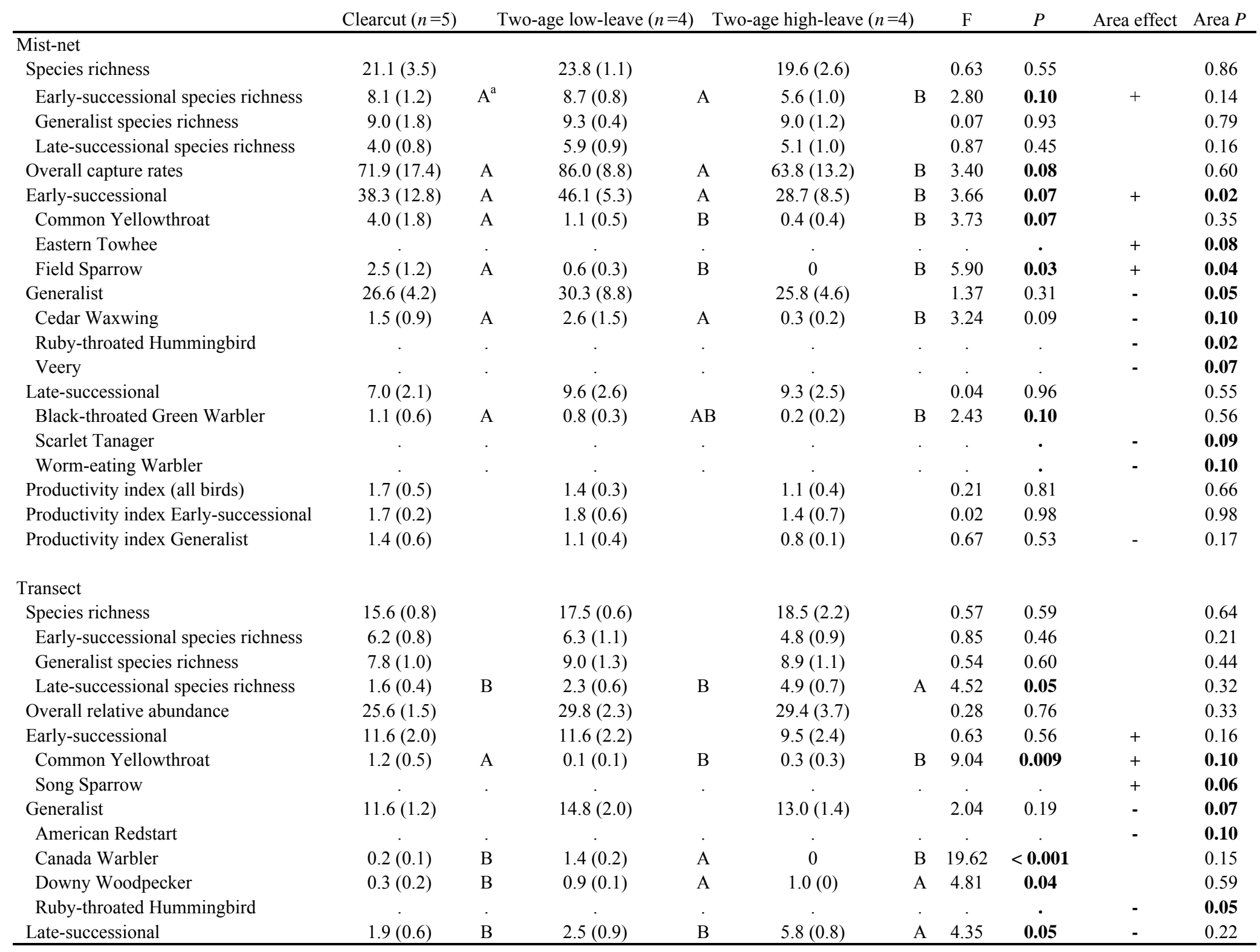

${ }^{a}$ Treatment means with different letters differ by least squares means (adjusted for vegetation height). 
Table 3. Edge sensitive species sampled by transect and mist-net surveys from 2005-2006 in West Virginia. Estimate indicates relationship of bird variable to distance to forested edge of stand. Only species with a significant edge effect ( $P \leq 0.10$; indicated by bold face) are presented.

\begin{tabular}{|c|c|c|c|}
\hline & Estimate & $\chi^{2}$ & $\operatorname{Pr}>\chi^{2}$ \\
\hline \multicolumn{4}{|l|}{ Mist-net } \\
\hline Species richness & . & 0.30 & 0.58 \\
\hline Early-successional species richness & . & 0.62 & 0.43 \\
\hline Generalist species richness & . & 0.06 & 0.80 \\
\hline Late-successional species richness & . & 0.04 & 0.85 \\
\hline Overall capture rates & . & 0.01 & 0.93 \\
\hline Early-successional & . & 0.03 & 0.87 \\
\hline Eastern Phoebe & 0.02 & 7.14 & 0.008 \\
\hline Field Sparrow & 0.01 & 3.67 & 0.06 \\
\hline Song Sparrow & -0.01 & 3.86 & 0.05 \\
\hline Generalist & . & 0.07 & 0.79 \\
\hline Downy Woodpecker & 0.01 & 3.39 & 0.07 \\
\hline Late-successional & . & 0.18 & 0.67 \\
\hline Black-throated Blue Warbler & -0.04 & 25.43 & $<0.001$ \\
\hline Black-throated Green Warbler & -0.02 & 5.29 & 0.02 \\
\hline Ovenbird & 0.01 & 5.82 & 0.02 \\
\hline \multicolumn{4}{|l|}{ Transect } \\
\hline Species richness & . & 0.86 & 0.35 \\
\hline Early-successional species richness & 0.004 & 3.44 & 0.06 \\
\hline Generalist species richness & . & 0.12 & 0.72 \\
\hline Late-successional species richness & . & 0.30 & 0.59 \\
\hline Overall relative abundance & . & 1.62 & 0.20 \\
\hline Early-successional & 0.004 & 3.78 & 0.05 \\
\hline American Goldfinch & 0.009 & 2.59 & 0.10 \\
\hline Common Yellowthroat & 0.02 & 9.58 & 0.002 \\
\hline Field Sparrow & 0.03 & 20.17 & $<0.001$ \\
\hline Mourning Warbler & 0.02 & 9.22 & 0.002 \\
\hline Generalist & . & 0.02 & 0.88 \\
\hline Canada Warbler & 0.01 & 4.97 & 0.03 \\
\hline Northern Flicker & -0.02 & 6.71 & 0.01 \\
\hline Rose-breasted Grosbeak & -0.05 & 21.20 & $<0.001$ \\
\hline Ruby-throated Hummingbird & 0.01 & 3.61 & 0.06 \\
\hline Wood Thrush & -0.03 & 10.50 & 0.001 \\
\hline Late-successional & . & 0.21 & 0.64 \\
\hline
\end{tabular}


Table 4. Periphery bird use of harvested study stands from 2005-2006 in West Virginia. Positive estimates indicate a greater relative abundance of birds near edges of stands with high retained basal area, vegetation height, or area.

\begin{tabular}{lcccccccccc} 
& \multicolumn{3}{c}{ Basal area } & \multicolumn{3}{c}{ Vegetation height } & \multicolumn{2}{c}{ Stand size } \\
& Estimate & $\chi^{2}$ & $\operatorname{Pr}>\chi^{2}$ & Estimate & $\chi^{2}$ & $\operatorname{Pr}>\chi^{2}$ & Estimate & $\chi^{2}$ & $\operatorname{Pr}>\chi^{2}$ \\
\cline { 2 - 9 } Periphery transect & & & & & & & & & \\
Species richness & 0.008 & 0.58 & 0.44 & 0.005 & 0 & 0.95 & 0.004 & 0.03 & 0.87 \\
Overall relative abundance & -0.004 & 0.22 & 0.64 & 0.06 & 0.53 & 0.47 & -0.01 & 0.29 & 0.59 \\
Early-successional & -0.04 & 0.98 & 0.32 & -0.43 & 1.56 & 0.21 & -0.08 & 0.79 & 0.37 \\
Generalist & 0.002 & 0.03 & 0.87 & 0.04 & 0.14 & 0.71 & 0.003 & 0.01 & 0.94 \\
Blue Jay &. &. &. & 0.72 & 2.37 & $\mathbf{0 . 1}$ &. &. &. \\
Late-successional & 0.0001 & 0.00 & 0.99 & -0.13 & 0.9 & 0.34 & -0.02 & 0.32 & 0.57 \\
$\quad$ Scarlet Tanager &. &. &. & 0.66 & 3.35 & $\mathbf{0 . 0 7}$ &. &. &. \\
$\quad$ White-breasted Nuthatch &. &. &. & -0.98 & 5.48 & $\mathbf{0 . 0 2}$ & -0.16 & 3.29 & $\mathbf{0 . 0 7}$ \\
\hline
\end{tabular}

$P$ values were considered statistically significant at the 0.10 level (bold face). 


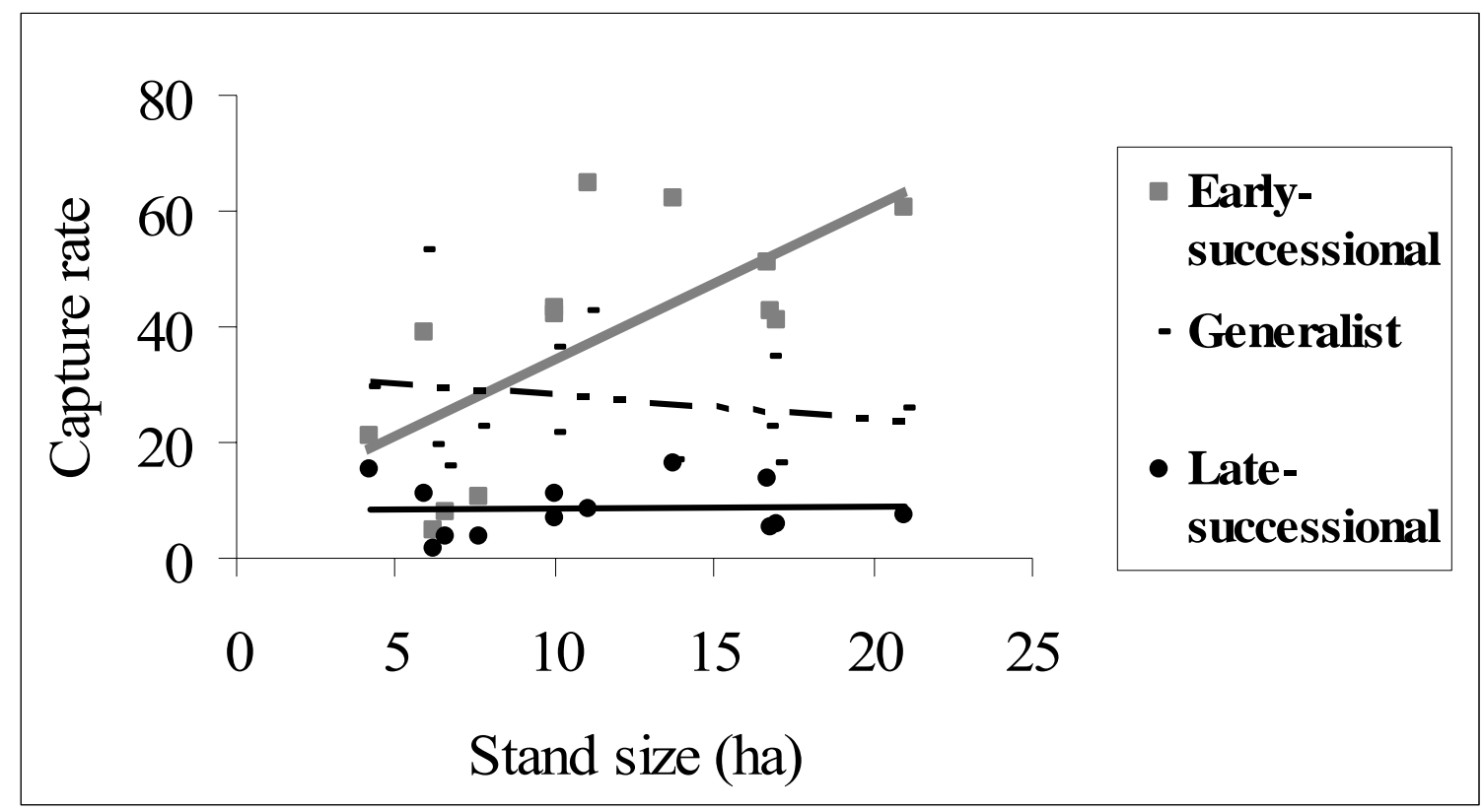

Figure 1. Relationship between stand size and capture rate (per 100 net-hours) for three habitat guilds sampled by mist-nets in West Virginia post-breeding during 2005-2006.

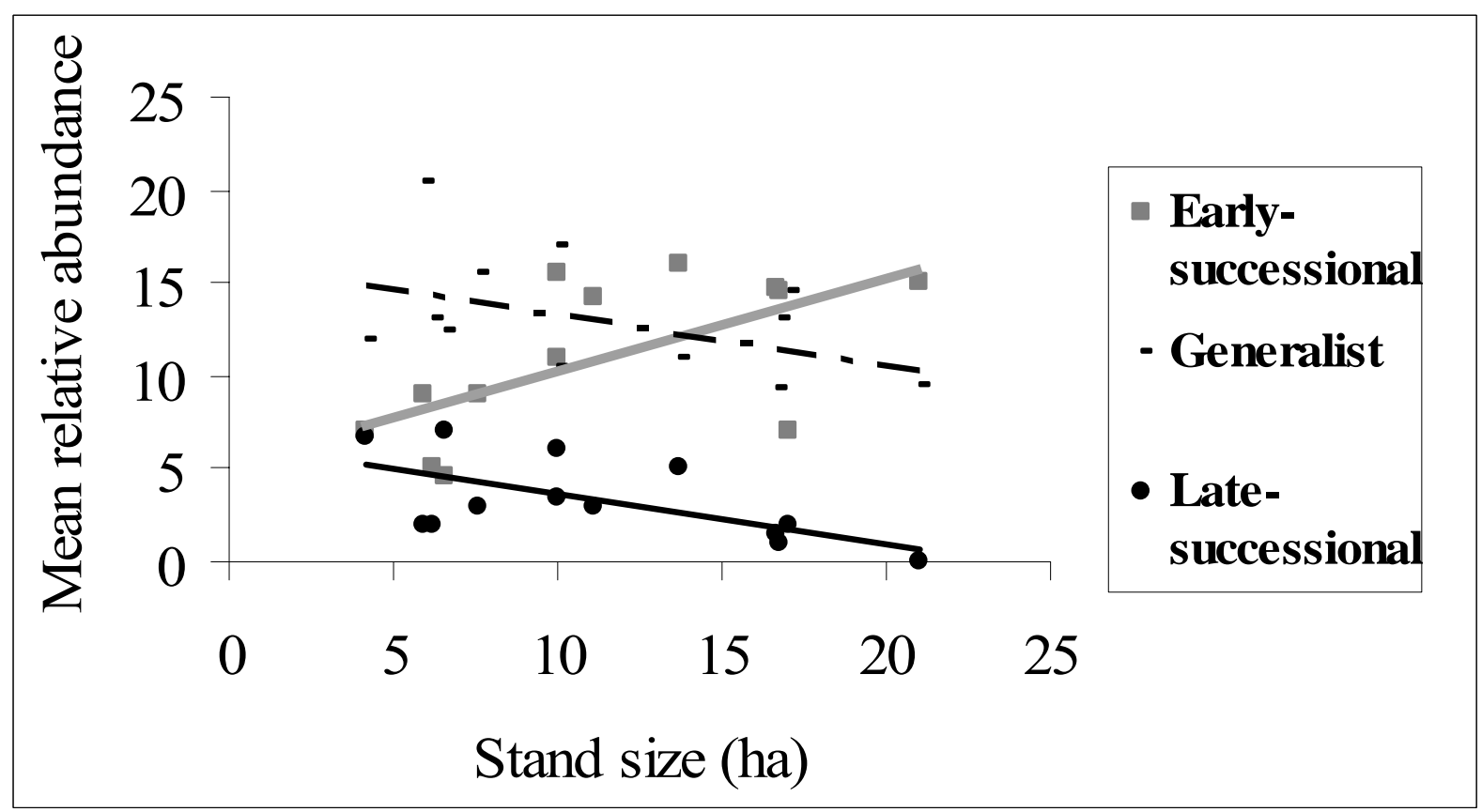

Figure 2. Relationship between stand size and mean relative abundance for three habitat guilds sampled by transect surveys in West Virginia post-breeding during 2005-2006. 
Appendix A. Species of hatch year birds (HY) and adults (AHY) by habitat guild captured by mist-nets and all ages detected within $50 \mathrm{~m}$ by transects between late June and mid-August in 2005-2006 in West Virginia.

\begin{tabular}{|c|c|c|c|c|c|c|c|c|}
\hline Species & Scientific name & $\begin{array}{c}\text { HY } \\
\text { captures }\end{array}$ & $\begin{array}{c}\text { AHY } \\
\text { captures }\end{array}$ & $\begin{array}{c}\text { Total } \\
\text { captures }\end{array}$ & $\begin{array}{c}\% \\
\text { stands }\end{array}$ & $\begin{array}{c}\text { Transect } \\
\text { detections } \\
\left(\text { middle) }{ }^{\mathrm{a}}\right.\end{array}$ & $\begin{array}{c}\% \\
\text { stands }\end{array}$ & $\begin{array}{c}\text { Transect } \\
\text { detections } \\
\text { (periphery) }\end{array}$ \\
\hline \multicolumn{9}{|l|}{ Early-successional species } \\
\hline Chestnut-sided Warbler & Dendroica pensylvanica & 259 & 218 & 477 & 100 & 89 & 100 & 7 \\
\hline Gray Catbird & Dumetella carolinensis & 55 & 73 & 128 & 85 & 47 & 77 & 5 \\
\hline Indigo Bunting & Passerina cyanea & 35 & 77 & 112 & 92 & 69 & 92 & 2 \\
\hline Song Sparrow & Melospiza melodia & 34 & 39 & 73 & 69 & 17 & 38 & 0 \\
\hline Common Yellowthroat & Geothlypis trichas & 25 & 39 & 64 & 54 & 24 & 38 & 0 \\
\hline Eastern Towhee & Pipilo erythrophthalmus & 16 & 30 & 46 & 92 & 55 & 100 & 16 \\
\hline Field Sparrow & Spizella pusilla & 14 & 19 & 33 & 46 & 6 & 31 & 0 \\
\hline Mourning Warbler & Oporornis philadelphia & 13 & 9 & 22 & 54 & 5 & 23 & 0 \\
\hline American Goldfinch ${ }^{\mathrm{b}}$ & Carduelis tristis & 0 & 14 & 14 & 38 & 20 & 69 & 2 \\
\hline Eastern Phoebe & Sayornis phoebe & 5 & 5 & 10 & 31 & 1 & 8 & 0 \\
\hline Carolina Wren & Thryothorus ludovicianus & 1 & 5 & 6 & 23 & 0 & 0 & 1 \\
\hline Blue-winged Warbler & Vermivora pinus & 1 & 4 & 5 & 15 & 1 & 8 & 0 \\
\hline Chipping Sparrow & Spizella passerina & 3 & 0 & 3 & 15 & 0 & 0 & 0 \\
\hline Traill's Flycatcher $^{\mathrm{c}}$ & Empidonax sp. & 1 & 1 & 2 & 15 & 0 & 0 & 0 \\
\hline Yellow-breasted Chat & Icteria virens & 0 & 2 & 2 & 8 & 1 & 8 & 0 \\
\hline Northern Cardinal & Cardinalis cardinalis & 1 & 0 & 1 & 8 & 0 & 0 & 0 \\
\hline Mourning Dove & Zenaida macroura & 0 & 0 & 0 & 0 & 4 & 31 & 1 \\
\hline \multicolumn{9}{|l|}{ Generalist species } \\
\hline Veery & Catharus fuscescens & 44 & 79 & 123 & 100 & 40 & 85 & 1 \\
\hline Hooded Warbler & Wilsonia citrina & 32 & 84 & 116 & 85 & 42 & 69 & 24 \\
\hline Red-eyed Vireo & Vireo olivaceus & 14 & 93 & 107 & 85 & 22 & 62 & 38 \\
\hline American Redstart & Setophaga ruticilla & 43 & 41 & 84 & 85 & 21 & 69 & 3 \\
\hline Canada Warbler & Wilsonia canadensis & 35 & 41 & 76 & 77 & 9 & 46 & 0 \\
\hline Ruby-throated Hummingbird & Archilochus colubris & 29 & 27 & 56 & 69 & 8 & 46 & 1 \\
\hline Cedar Waxwing $^{\mathrm{b}}$ & Bombycilla cedrorum & 1 & 36 & 37 & 54 & 57 & 85 & 3 \\
\hline Dark-eyed Junco & Junco hyemalis & 25 & 11 & 36 & 85 & 6 & 31 & 8 \\
\hline Black-capped Chickadee & Poecile atricapilla & 13 & 11 & 24 & 54 & 26 & 85 & 14 \\
\hline Rose-breasted Grosbeak & Pheucticus ludovicianus & 8 & 14 & 22 & 69 & 6 & 31 & 3 \\
\hline Wood Thrush & Hylocichla mustelina & 13 & 8 & 21 & 46 & 6 & 23 & 14 \\
\hline Downy Woodpecker & Picoides pubescens & 9 & 1 & 10 & 46 & 13 & 77 & 6 \\
\hline American Robin & Turdus migratorius & 5 & 2 & 7 & 15 & 13 & 46 & 2 \\
\hline Northern Flicker & Colaptes auratus & 5 & 2 & 7 & 38 & 9 & 62 & 4 \\
\hline Baltimore Oriole & Icterus galbula & 2 & 0 & 2 & 15 & 1 & 8 & 1 \\
\hline Yellow Warbler $^{\mathrm{d}}$ & Dendroica petechia & 2 & 0 & 2 & 8 & 0 & 0 & 0 \\
\hline Black-billed Cuckoo & Coccyzus erythropthalmus & 0 & 1 & 1 & 8 & 1 & 8 & 1 \\
\hline Blue-gray Gnatcatcher & Polioptila caerulea & 1 & 0 & 1 & 8 & 2 & 8 & 2 \\
\hline Brown-headed Cowbird & Molothrus ater & 1 & 0 & 1 & 8 & 2 & 15 & 0 \\
\hline Yellow-throated Vireo & Vireo flavifrons & 1 & 0 & 1 & 8 & 2 & 8 & 0 \\
\hline American Crow & Corvus brachyrhynchos & 0 & 0 & 0 & 0 & 0 & 0 & 3 \\
\hline Blue Jay & Cyanocitta cristata & 0 & 0 & 0 & 0 & 3 & 15 & 13 \\
\hline House Wren & Troglodytes aedon & 0 & 1 & 1 & 8 & 1 & 8 & 0 \\
\hline Northern Parula & Parula americana & 0 & 0 & 0 & 0 & 0 & 0 & 1 \\
\hline Red-bellied Woodpecker & Melanerpes carolinus & 0 & 0 & 0 & 0 & 2 & 8 & 0 \\
\hline Ruffed Grouse & Bonasa umbellus & 0 & 0 & 0 & 0 & 7 & 31 & 3 \\
\hline Tufted Titmouse & Baeolophus bicolor & 0 & 0 & 0 & 0 & 1 & 8 & 0 \\
\hline Yellow-billed Cuckoo & Coccyzus americanus & 0 & 0 & 0 & 0 & 0 & 0 & 3 \\
\hline
\end{tabular}


Appendix A continued

\begin{tabular}{|c|c|c|c|c|c|c|c|c|}
\hline Species & Scientific name & $\begin{array}{c}\text { HY } \\
\text { captures }\end{array}$ & $\begin{array}{c}\text { AHY } \\
\text { captures }\end{array}$ & $\begin{array}{c}\text { Total } \\
\text { captures }\end{array}$ & $\begin{array}{c}\% \\
\text { stands }\end{array}$ & $\begin{array}{c}\text { Transect } \\
\text { detections } \\
(\text { middle })^{\mathrm{a}}\end{array}$ & $\begin{array}{c}\% \\
\text { stands }\end{array}$ & $\begin{array}{l}\text { Transect } \\
\text { detections } \\
\text { (periphery) }\end{array}$ \\
\hline \multicolumn{9}{|l|}{ Late-successional species } \\
\hline Black-and-white Warbler & Mniotilta varia & 36 & 25 & 61 & 77 & 15 & 62 & 5 \\
\hline Ovenbird & Seiurus aurocapillus & 15 & 26 & 41 & 100 & 1 & 8 & 2 \\
\hline Black-throated Green Warbler & Dendroica virens & 12 & 10 & 22 & 62 & 2 & 15 & 12 \\
\hline Magnolia Warbler & Dendroica magnolia & 7 & 14 & 21 & 62 & 2 & 8 & 1 \\
\hline Worm-eating Warbler & Helmitheros vermivorus & 7 & 8 & 15 & 54 & 0 & 0 & 0 \\
\hline Black-throated Blue Warbler & Dendroica caerulescens & 7 & 4 & 11 & 38 & 0 & 0 & 2 \\
\hline Scarlet Tanager & Piranga olivacea & 4 & 7 & 11 & 38 & 13 & 46 & 12 \\
\hline Winter Wren & Troglodytes troglodytes & 6 & 2 & 8 & 31 & 1 & 8 & 2 \\
\hline Least Flycatcher & Empidonax minimus & 6 & 1 & 7 & 38 & 1 & 8 & 1 \\
\hline Blackburnian Warbler & Dendroica fusca & 6 & 0 & 6 & 23 & 0 & 0 & 0 \\
\hline Hermit Thrush & Catharus guttatus & 5 & 1 & 6 & 31 & 0 & 0 & 1 \\
\hline Hairy Woodpecker & Picoides villosus & 3 & 2 & 5 & 23 & 4 & 31 & 4 \\
\hline Acadian Flycatcher & Empidonax virescens & 3 & 1 & 4 & 31 & 0 & 0 & 4 \\
\hline Kentucky Warbler & Oporornis formosus & 1 & 3 & 4 & 15 & 1 & 8 & 0 \\
\hline Brown Creeper & Certhia americana & 2 & 0 & 2 & 8 & 0 & 0 & 0 \\
\hline Cerulean Warbler & Dendroica cerulea & 1 & 1 & 2 & 15 & 4 & 15 & 3 \\
\hline Tennessee Warbler $^{\mathrm{d}}$ & Vermivora peregrina & 0 & 2 & 2 & 15 & 0 & 0 & 0 \\
\hline White-breasted Nuthatch & Sitta carolinensis & 1 & 0 & 1 & 8 & 20 & 69 & 13 \\
\hline Sharp-shinned Hawk & Accipiter striatus & 0 & 1 & 1 & 8 & 0 & 0 & 0 \\
\hline Blue-headed Vireo & Vireo solitarius & 0 & 0 & 0 & 0 & 3 & 23 & 2 \\
\hline Eastern Wood-Pewee & Contopus virens & 0 & 0 & 0 & 0 & 1 & 8 & 1 \\
\hline Pileated Woodpecker & Dryocopus pileatus & 0 & 0 & 0 & 0 & 1 & 8 & 1 \\
\hline Yellow-bellied Sapsucker & Sphyrapicus varius & 0 & 0 & 0 & 0 & 2 & 8 & 2 \\
\hline Totals & & 868 & 1095 & 1963 & & 710 & & 250 \\
\hline
\end{tabular}

${ }^{a}$ Middle transect covered $100 \mathrm{~m}$ (50 on each side of transect) whereas periphery transect covered $50 \mathrm{~m}$ from edge of stand.

${ }^{\mathrm{b}}$ These species had no post-breeding individuals.

${ }^{\mathrm{c}}$ Willow (E. traillii ) or Alder Flycatcher (E. alnorum ).

${ }^{\mathrm{d}}$ Not locally breeding species. 